\title{
EARLY FRANCISCAN PAINTED PANELS AS A RESPONSE TO THE ITALIAN CATHARS
}

\author{
A Dissertation \\ presented to \\ the Faculty of the Graduate School \\ at the University of Missouri-Columbia \\ In Partial Fulfillment of the \\ Requirements for the Degree \\ Doctor of Philosophy \\ by \\ REBECCA ANNE HERTLING RUPPAR \\ Dr. Anne Rudloff Stanton, \\ Dissertation Supervisor
}

JULY 2020 
(C) Copyright by Rebecca A.H. Ruppar, 2020.

All rights reserved. 
The undersigned, appointed by the dean of the Graduate School, have examined the dissertation entitled

\section{EARLY FRANCISCAN PAINTED PANELS} AS A RESPONSE TO THE ITALIAN CATHARS

presented by Rebecca Anne Hertling Ruppar,

a candidate for the degree of Doctor of Philosophy, and hereby certify that, in their opinion, it is worthy of acceptance.

Professor Anne Rudloff Stanton

Professor Jill Raitt

Professor Marcus Rautman

Professor Alisa McCusker 


\section{DEDICATION}

Thank you to my dad who believed in me before I believed in myself and my mom who taught me to look for beauty and find it in unexpected places...

To my brothers and sister for laughing with me through the process...

And especially to my husband, Todd, and my sons, Paul and Edward, for their

immeasurable love, boundless patience, and unwavering encouragement. I could not have achieved my dream without you. 


\section{ACKNOWLEDGMENTS}

I extend my heartfelt gratitude to my dissertation committee: Jill Raitt, whose personal and academic brilliance challenged and inspired me, Marcus Rautman, whose enthusiasm and humor introduced me to the joys of looking further back and turning my attention to the East, Alisa McCusker, whose understanding of material artifacts motivated deeper exploration, and especially to my advisor and confidant Anne Rudloff Stanton, whose rich knowledge and skillful counsel expanded my thinking and guided my writing with unfailing patience, incomparable wit, and gentle encouragement.

I am grateful to the John D. Bies International Travel Scholarship and the Edzard Baumann Memorial Travel Award, for their support of my research in Italy and France. The following people also contributed generously to my work there: Pierpaolo Mangani, Abbondio Zuppante, Adele Breda, Silvia Milana, Donatella Vaccari, Rosella Cavigli, Alessandro Benci, Iane Donnini, Elena Pinzauti, Sara Sabbatini, Precious Osayi, Claudia Timossi, Cinzia Pini, Lisa DiZanni, Fr. Stephen McMichael, O.F.M. Conv., Fr. Wayne Hellmann, O.F.M. Conv., Noël and Mia Devisch, and the Poor Clare sisters of the Basilica di Santa Chiara in Assisi. 


\section{Table of Contents}

Acknowledgments .................................................................................................... ii

List of Figures.........................................................v

Abstract.................................................................xi

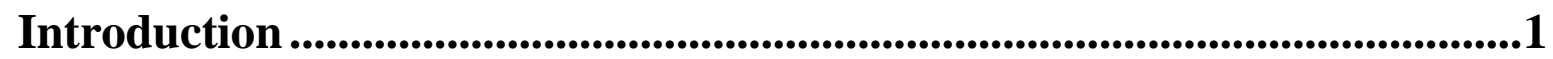

The State of the Field ......................................................................................................................... 5

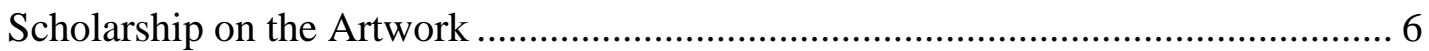

Scholarship on the Cathars.................................................................................... 14

Scholarship on the Franciscans ......................................................................... 27

Chapter 1: Heresy and Reform..............................................................................33

The Religious and Historical Context ..................................................................................... 33

Catharism in Italy ......................................................................................................... 47

Response of the Church....................................................................................................... 50

Francis of Assisi, Founding Brother............................................................................... 54

The Fourth Lateran Council Addresses Heresy ............................................................... 56

Chapter 2 Art and Materiality ..................................................................................61

Cathars and Materiality ......................................................................................................... 61

The Artistic Context of the Early Franciscans................................................................. 66

The History and Spiritual Depth of Wood-Panel Paintings ....................................... 69

Chapter 3: Icons of Francis as Orthodox Exemplar in Opposition to the Cathar Perfecti .........................................................................................................87

Francis as Orthodox Preacher in Contrast to the Cathar Perfecti........................... 97

Francis as Alter Christus Manifested in the Stigmata................................................ 111

Chapter 4. Vita Dossals as a Response to the Cathar Heresy ...................121

Scenes of Physical Healing .................................................................................................... 128

Incarnation and Real Presence in the Eucharist..................................................... 136

Nature in the Vita Dossals..................................................................................................... 141 


\section{Chapter 5 Countering Heresy through the Theology and Materiality of}

the Painted-Panel Crucifixes

The Original Franciscan Cross and its Environs................................................... 161

Byzantine Framework ............................................................................................................. 166

The Crucifixes and the Early Franciscan Texts.......................................................... 172

Focus on the Doctrine of the Incarnation ..................................................................... 175

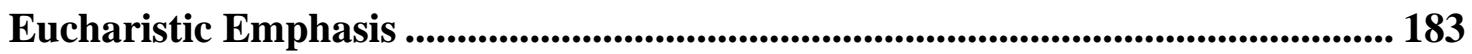

Companions at the Cross................................................................................................ 188

Tortured Physicality ................................................................................................................. 195

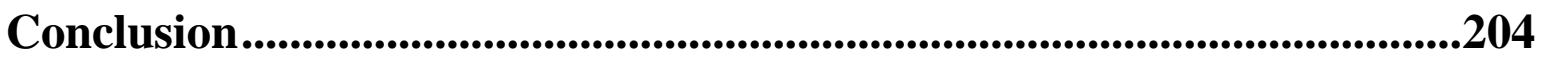

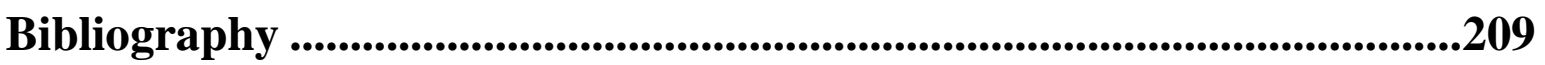

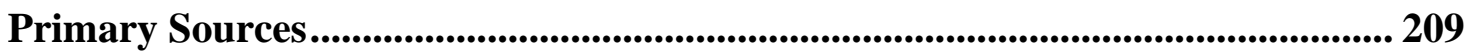

Secondary Sources .......................................................................................................................... 210

Appendices ............................................................................................................................241

Appendix 1 Fourth Lateran Council: Canon 3 on Heresy (1215) ........................... 241

Appendix 2 Relevant text of On the Reduction of the Arts to Theology, Bonaventure..................................................................................................................... 242

Appendix 3 The Manger He Made in Celebration of the Lord's Birthday, Thomas of Celano, Vita Prima Chapter XXX ........................................................................... 244

Appendix 4 The Account of the Nativity at Greccio, Bonaventure, Legenda Maior Chapter X .................................................................................................................. 246

Appendix 5 The First Admonition, The Body of Christ, Francis of Assisi.......... 248

Appendix 6 The Canticle of the Creatures, Francis of Assisi .................................. 249

Appendix 7 Sermon to the Birds, Thomas of Celano, Vita Prima Chapter XXI. 251 Appendix 8 Sermon to the Birds, Bonaventure, Legenda Maior Chapter XII.... 252 Appendix 9 The Spirit of Charity and the Feeling of Compassion for the Poor that Glowed in Him for What He Did with the Sheep and the Lambs, Thomas of Celano, Vita Prima Chapter XXVIII ............................................................................ 253

Appendix 10 Relevant Bibliography for Artwork ....................................................... 262

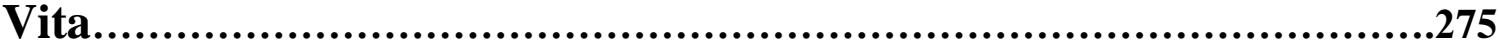




\section{List of Figures}

Chapter 2 Art and Materiality

Figure 2.1 Maestro del Crocifisso di Gualdo Tadino, Crocifisso con San Francesco (verso), Museo Civico Rocca Flea, Gualdo Tadino.

Figure 2.2 Maestro del Crocifisso di Gualdo Tadino, Crocifisso con San Francesco (verso, detail of fabric underlayer between boards), Museo Civico Rocca Flea, Gualdo Tadino 221

Figure 2.3 Expressionist Master of Santa Chiara, Cristo Crocifisso, Chiesa Museo di San Francesco, Montefalco (detail showing fabric underlayer between wood and gesso)

Figure 2.4 Maestro del San Francesco di Orte, San Francesco e Quattro Scene (detail of moldings), Museo d'Arte Sacra di Orte

Figure 2.5 Guido di Graziano (Guido of Siena), San Francesco e Storie della sua Vita (detail, compass guided, stamped and etched halo), Pinacoteca Nazionale di Siena (Formerly in San Francesco in Colle Val d'Elsa) .............................................. 223

Figure 2.6 Lex Lucis Spoletina, environmental law at Monteluca............................ 223

Figure 2.7 View of the Spoleto Valley from Monteluco............................................. 224

Figure 2.8 Margarito d'Arezzo, San Francesco, Pinacoteca Comunale, Castiglion Fiorentino. 224

\section{Chapter 3 Icons of Francis as Orthodox Exemplar in Opposition to the Cathar Perfecti.

Figure 3.1 San Francesco, Benedictine Monastery in Subiaco, Italy 225

Figure 3.2 Margarito d'Arezzo and assistant, San Francesco, Galleria e Museo Medievale e Moderno, Arezzo (originally from Sargiano).

Figure 3.3 Margarito d'Arezzo, San Francesco, Vatican Pinacoteca, Rome ...... 225

Figure 3.4 John Chrysostom, mosaic detail from Palatine Chapel, Sicily ............ 225

Figure 3.5 Attributed to Maestro della Croce Coppo di Marcovaldo, San Francesco, Storie della sua Vita e Miracoli Dopo la Morte (detail, Francis Preaching to a Crowd), Museo Civici di Pistoia. 
Figure 3.6 Sano di Pietro, Predicación de San Bernardino por Sano di Pietro (detail). Museo dell'Opera del Duomo, Siena. c. 1540.

Figure 3.7 Bonaventura Berlinghieri, San Francesco e Storie della sua Vita (detail, Stigmatization), Chiesa di San Francesco, Pescia 226

Figure 3.8 Maestro del San Francesco Bardi (possibly Coppo di Marcovaldo, San Francesco e Venti Storie della sua Vita (detail, Stigmatization), Basilica di Santa Croce, Cappella Bardi, Florence 226

Figure 3.9 Attributed to Maestro della Croce Coppo di Marcovaldo, San Francesco, Storie della sua Vita e Miracoli Dopo la Morte (detail, Stigmatization), Museo Civici di Pistoia 226

Figure 3.10 Maestro del San Francesco di Orte, San Francesco e Quattro Scene (detail, Stigmatization), Museo d'Arte Sacra di Orte.

Figure 3.11 Guido di Graziano, San Francesco e Storie della sua Vita (detail, Stigmatization), Pinacoteca Nazionale di Siena

Figure 3.12 St. Francis Master, San Francesco, Museo della Porziuncola, Santa Maria degli Angeli, Assisi.

Figure 3.13 Anonymous Roman Artist, Saint François d'Assise, Musée du Louvre, Paris. 228

Figure 3.14 Cimabue, San Francesco, Assisi, Museo della Porziuncola, Santa Maria degli Angeli. 228

Chapter 4 Vita Dossals as a Response to the Cathar Heresy

Figure 4.1 Reconciliation of a Cathar, from San Francesco e Quattro Scene, Museo d'Arte Sacra di Orte. 229

Figure 4.2 San Francesco e Quattro Scene, Museo d'Arte Sacra di Orte 229

Figure 4.3 Reconciliation with an Icon, from San Francesco e Quattro Scene, Museo d'Arte Sacra di Orte.

Figure 4.4 Bonaventura Berlinghieri. San Francesco e Storie della sua Vita, Chiesa di San Francesco, Pescia 229

Figure 4.5 Healing of the Girl with the Twisted Neck, detail from San Francesco $e$ Storie della sua Vita, Chiesa di San Francesco, Pescia. 
Figure 4.6 Healing of the Girl with the Twisted Neck and Exorcism, detail from San Francesco e Venti Storie della sua Vita, Basilica di Santa Croce, Cappella Bardi, Florence.

Figure 4.7 Healing of the Girl with the Twisted Neck, from San Francesco, Storie della sua Vita e Miracoli Dopo la Morte, Museo Civici di Pistoia.

Figure 4.8 Healing of the Girl with the Twisted Neck, detail from San Francesco $e$ Quattro Miracoli, Museo del Tesoro della Basilica di San Francesco, Assisi....... 230

Figure 4.9 Healing of the Girl with the Twisted Neck, from San Francesco $e$ Quattro Miracoli Post-Mortem, Vatican Pinacoteca, Rome

Figure 4.10 Healing of the Girl with the Twisted Neck, detail from Dossale con San Francesco e Sei Miracoli, Museo Nazionale di San Matteo, Pisa

Figure 4.11 Healing of Bartholomew of Narni, detail from San Francesco e Storie della sua Vita, Chiesa di San Francesco, Pescia.

Figure 4.12 Healing of Bartholomew of Narni, detail from San Francesco e Venti Storie della sua Vita, Basilica di Santa Croce, Cappella Bardi, Florence 231

Figure 4.13 Healing of Bartholomew of Narni, from San Francesco, Storie della sua Vita e Miracoli Dopo la Morte, Museo Civici di Pistoia 231

Figure 4.14 Healing of Bartholomew of Narni, detail from San Francesco $e$ Quattro Miracoli, Museo del Tesoro della Basilica di San Francesco, Assisi.

Figure 4.15 Healing of Bartholomew of Narni, from San Francesco e Quattro Miracoli Post-Mortem, Vatican Pinacoteca, Rome. 231

Figure 4.16 Healing of Bartholomew of Narni, detail from Dossale con San Francesco e Sei Miracoli, Museo Nazionale di San Matteo, Pisa 231

Figure 4.17 Healing of Child's Eyes on the Feast of St. Francis, from Dossale con San Francesco e Sei Miracoli, Museo Nazionale di San Matteo, Pisa 232

Figure 4.18 Nativity at Greccio, detail from San Francesco e Venti Storie della sua Vita, Basilica di Santa Croce, Cappella Bardi, Florence 232

Figure 4.19 Nativity at Greccio, from San Francesco e Storie della sua Vita, Pinacoteca Nazionale di Siena. 232

Figure 4.20 Sermon to the Birds, detail from San Francesco e Storie della sua Vita, Chiesa di San Francesco, Pescia 232 
Figure 4.21 Sermon to the Birds, detail from San Francesco e Venti Storie della sua Vita, Basilica di Santa Croce, Cappella Bardi, Florence

Figure 4.22 Sermon to the Birds, from San Francesco e Quattro Scene, Museo d'Arte Sacra di Orte

Figure 4.23 Sermon to the Birds, from San Francesco e Storie della sua Vita, Pinacoteca Nazionale di Siena.

Figure 4.24 Francis Ransoms the Lambs from Among the Goats, detail from San Francesco e Venti Storie della sua Vita, Basilica di Santa Croce, Cappella Bardi, Florence. 233

Figure 4.25 Francis Exchanges his Cloak for Two Lambs a Shepherd is Carrying to Slaughter, detail from San Francesco e Venti Storie della sua Vita, Basilica di Santa Croce, Cappella Bardi, Florence. 233

Figure 4.26 Stigmatization, detail from San Francesco e Storie della sua Vita, Pinacoteca Nazionale di Siena.

Figure 4.27 Assisi townscape, detail from San Francesco e Quattro Miracoli, Museo del Tesoro della Basilica di San Francesco, Assisi

Figure 4.28 Altars in the Exorcism and Healing of Pilgrims scenes, detail from San Francesco e Quattro Miracoli, Museo del Tesoro della Basilica di San Francesco, Assisi

Figure 4.29 Altar in the Lower Basilica of San Francesco, Assisi 234

\section{Chapter 5 Countering Heresy through the Theology and Materiality of} the Painted-Panel Crucifixes

Figure 5.1 Cross of Maestro Guglielmo, Cathedral of Sarzana, Italy . 234

Figure 5.2 Cross of Maestro Guglielmo (in situ), Cathedral of Sarzana, Italy..... 234

Figure 5.3 Cross of San Damiano in the Basilica of Santa Chiara, Assisi, Italy.. 234

Figure 5.4 Theoretical Format of lower part of Giunta Pisano's Crucifix for the

Basilica di San Francesco 235

Figure 5.5 Giunta Pisano, Crucifix of Santa Maria degli Angeli alla Porziuncola, Assisi. 236

Figure 5.6 Verification of the Stigmata, Upper Basilica of San Francesco, Assisi 237 
Figure 5.7 Nativity at Greccio, Upper Basilica of San Francesco, Assisi.

Figure 5.8 Crucifixion wall painting in the Church of Nemanja in the Studenica Monastery

Figure 5.9 Crucifixion wall painting in the Church of the Resurrection in the Žiča

Monastery

Figure 5.10 The Entry into Jerusalem, the Crucifixion, and the Harrowing of Hell, from the Dodecaorton Epistyle, Chapel of Constantine and Helena, Monastery of St. Catherine, Mount Sinai, Egypt

Figure 5.11 The Ascension, Pentecost, and Dormition, from the Dodecaorton Epistyle, Chapel of Constantine and Helena, Monastery of St. Catherine, Mount Sinai, Egypt.

Figure 5.12 Baptism of Christ, the Transfiguration, and the Raising of Lazarus, from the Dodecaorton Epistyle, Chapel of St. George, Monastery of St. Catherine, Mount Sinai, Egypt ......................................................................................................... 238

Figure 5.13 Annunciation, the Nativity, and Jesus' Presentation in the Temple, from the Dodecaorton Epistyle, Chapel of St. George, Monastery of St. Catherine,

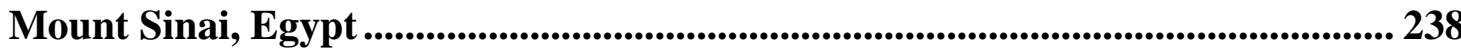

Figure 5.14 Crocifisso con San Francesco, Basilica di San Francesco, Arezzo, Italy by a Follower of Master of Santa Chiara. 238

Figure 5.15 Basilica di San Francesco (interior), Arezzo ................................... 238

Figure 5.16 Crocifisso con San Francesco (detail), Basilica di San Francesco (interior), Arezzo.

Figure 5.17 Drawing based on Kurt Weitzman's photo of Cod. 1186, 79r with examples of early Christian illustrations of the Temple Curtain 239

Figure 5.18 Examples of Apron Decoration from the Crucifixes in Arezzo, Perugia, Spello.

Figure 5.19 Maestro di San Francesco, Crocifisso con San Francesco, Galleria Nationale dell'Umbria, Perugia

Figure 5.20 Expressionist Master of Santa Chiara, Cristo Crocifisso, Chiesa Museo di San Francesco, Montefalco. 240

Figure 5.21 Maestro di San Francesco, Crocifisso con San Francesco (suppedaneo detail), Galleria Nationale dell'Umbria, Perugia 240

Figure 5.22 Expressionist Master of Santa Chiara or Maestro Umbro-Giottesco, Crocifisso Tempera su tavola, Chiesa di Sant' Andrea, Spello. 240 
Catalogs .....................................................................................................................260

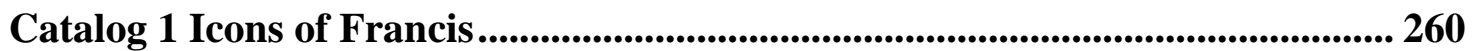

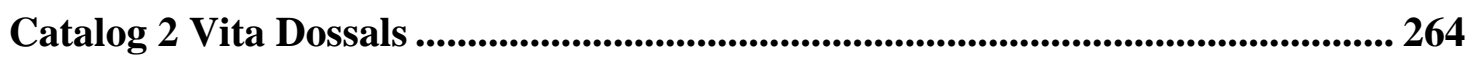

Catalog 3 Painted Wood-Panel Crucifixes ........................................................................ 268

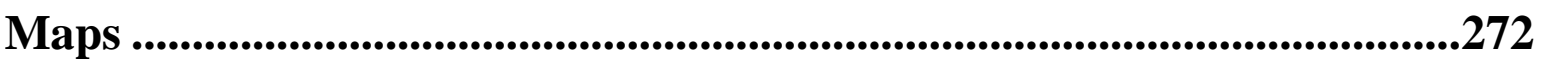

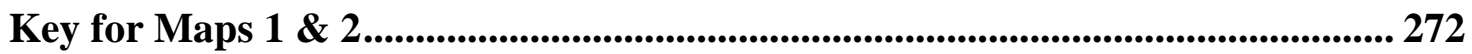

Map 1 Thirteenth Century Wood-Panel Art Compared to Cathar Routes ......... 273

Map 2 Thirteenth Century Wood-Panel Art compared with known Cathar

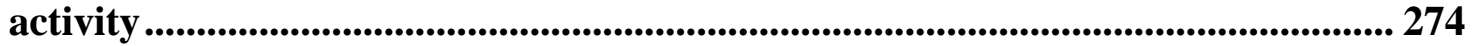

Map 3 Italy in the Twelfth and Thirteenth Centuries, Adapted from Muir's Historical Atlas (1911) ......................................................................................................... 274 


\title{
EARLY FRANCISCAN PAINTED PANELS AS A RESPONSE TO THE ITALIAN CATHARS
}

\author{
Rebecca Ruppar
}

Dr. Anne Rudloff Stanton, Dissertation Supervisor

\begin{abstract}
The wood-panel paintings created by the Franciscan order in the thirteenth century present a dramatic transition from a static, stoic Byzantine style to increasing degrees of naturalistic, realistic, emotional, and corporeal representations. As a driving force behind the iconographic and stylistic shifts evident in these paintings, this study presents the parallel relationship between Francis of Assisi and his mendicant brothers to the heterodox Christian community known as the Cathars, a religious sect that competed directly with the Order of Friars Minor and the Catholic Church in duecento Italy. Using portable and monumental artwork to cultivate orthodox beliefs among the laity, the early Franciscan order positioned itself as one of the most prolific and innovative patrons of the arts nearly from the order's inception, despite their devotion to material poverty - a position that mirrored the ascetic Cathars.

Focusing on three compositional models, specifically, large full-length icons of Francis, vita dossals of the saint surrounded by hagiographic scenes, and outsized crucifixes with the poverello depicted at the foot of the cross, this study analyzes the artwork in light of the Franciscans' and Cathars' shared historical context, their divergent theological beliefs, and their intersecting material cultures. Iconographic and material examinations are informed by the writings of early friars and the scarce textual remnants of the persecuted heretics. Evidence indicates that images of Francis were set as a foil to the Cathar leaders and preachers, presenting the saint as alter Christus, as confirmed by the wounds of the stigmata. Painted representations of Francis' life and reported miracles further provided opportunities for the friars to catechize on doctrines that the Church had recently reaffirmed at its Fourth Lateran Council. The imagery of the icons, vita dossals, and crucifixes highlights orthodox Catholic teachings such as Jesus Christ's Incarnation and Real Presence in the Eucharist and his physical suffering at the Crucifixion, as well as the intrinsic goodness of the natural world — all of which repudiated the Cathars' dualist and docetist beliefs. While the community of the Cathars has long been discounted, the Franciscans' rich artistic reaction to refute heterodox beliefs makes clear that the relationship between these two mendicant groups should be recognized and further explored.
\end{abstract}




\section{Introduction}

My early world was saturated with images of Francis of Assisi-both living

models in the friars and sisters who served as tireless educators and the painted, sculpted, and stained glass works of art that filled my school and church. These images appeared joyful and gentle, sometimes glowering, sometimes whimsical—perpetually calling on the viewer to imitate the poor little man, the poverello, in his love of the crucified Christ and in his concern for the natural world. Thus, my fascination with Franciscan iconography took root many years ago. The present study began with several related questions: What conditions influenced the Order of Friars Minor to position themselves as one of the most prolific and innovative patrons of the arts in Italy from the thirteenth century through the Renaissance ${ }^{1}$ And within the array of early Franciscan artwork, why was there such a dramatic transition from a static, stoic Byzantine style to increasing degrees of naturalistic, realistic, emotional, and corporeal representations? ${ }^{2}$ Was it something within the person of Francis that led to the profusion of art-something in the spirit of those early brothers? Was it a broader theological shift in the Catholic church?

${ }^{1}$ Trinita Kennedy, Donal Cooper, Holly Flora, Amy Neff, Janet Robson, et al., Sanctity Pictured: The Art of the Dominican and Franciscan Orders in Renaissance Italy (London: Philip Wilson Publishers., 2014), vi; Bradley R. Franco, "The Functions of Franciscan Art," in The World of St. Francis of Assisi: Essays in Honor of William R. Cook, ed. Steven J. McMichael (Leiden: Brill, 2015), 42. For convenience, I will use of the modern names of countries and regions throughout this dissertation.

2 The term "Franciscan art" used through this dissertation refers to artworks commissioned by the First Order of Franciscans - the men avowed to follow in Francis of Assisi's teaching and way of life as members of a religious community. In the modern era, this order is divided into the Friars Minor, the Friars Minor Conventual, and the Friars Minor Capuchin, but these divisions did not formalize until after the period considered by this study. The Franciscans also have a Second Order composed of women following in the line of Clare of Assisi, and a Third Order of religious and lay people who remain in their secular commitments while adopting the spirit of Francis to the extant their vocation allows. The term "Franciscan art" further acknowledges that the order was the patron of the work or it was made for private or public use under the auspices of their foundations. It does not indicate a belief that the artists were religious brothers themselves, although in some cases they may have been. All the works studied in this project depict the founder of the order, Francis. 
Was it an external factor-a result of the Italian landscape or the thirteenth-century geopolitical milieu, or a cross-cultural depositing from returning crusaders? Perhaps all of the above affected the abundance of the order's artistic production. My questions were not unique or new. Scholars have been wrestling with the differences between artists like the traditional iconographer Berlinghieri and the proto-Renaissance genius of Giotto for centuries. ${ }^{3}$ While the query was not new, the answer, or at least one significant answer, was even older: the Cathars, a dualist Christian sect that thrived in western Europe in the thirteenth century. Yet despite this heterodoxy's prime position to influence Francis of Assisi, the religious order he founded, and those early mendicants' artistic endeavors, the Cathars have been nearly expunged from the historical record, first by the Catholic Church's inquisitors who persecuted them, and more recently by twenty-first century scholars who consider them to have been a construct of nineteenth to twentieth century academics—a bogey-man of dualist heresy. ${ }^{4}$

When a map of extant thirteenth-century painted wood-panel icons of Francis and crucifixes depicting the saint at the foot of the cross is combined with the bishoprics of the Cathar communities that were situated by 1200 , and theoretical routes as proposed by Malcolm Lambert (See Map 1), it becomes clear that these important Franciscan artworks are concentrated along a corridor of Cathar influence. This northern central collection of

\footnotetext{
${ }^{3}$ See for example Giorgio Vasari’s chapters on Cimabue and Giotto. Giorgio Vasari, Julia Conaway Bondanella, and Peter Bondanella, Lives of the Artists, Oxford World's Classics (Oxford University Press, 1998), 7-37. Scholars such as Daniel Cooper, Holly Flora, Bradley Franco, Trinita Kennedy, Amy Neff, and others have continued to probe this topic into our current decade.

${ }^{4}$ Dualism, at its most basic, is a belief in a cosmology based on two principles (good and evil) as independent and equivalent forces. This idea, as well as the historiographical controversies regarding the Cathars, will be explained more thoroughly in the next section and first chapter.
} 
Italian villages was a spiritual battleground from the Valley of Spoleto to Florence and Bologna, continuing northwest to Languedoc in what is now France. ${ }^{5}$

Few scholars have addressed the relationship between the Cathars and the Franciscans in general, and no in-depth study has explored whether such a relationship had a meaningful impact on the iconography of the religious order in the time immediately following the poverello. ${ }^{6}$ The goal of this project is to determine how the remaining evidence reveals how the Cathars' presence and influence may have affected the manner in which the early Franciscans portrayed their founder and the Catholic art in which he figured so prominently. In this study, I analyze the wood-panel paintings of the thirteenth-century Franciscans to compare and contrast the Catholic brothers to the Cathar believers, presenting each group's history, spirituality, culture, and connection to the visual and material. The Franciscan mission has been colloquially interpreted as "Preach the Gospel at all times. If necessary, use words. ${ }^{, 7}$ From the very origin of the religious order, the artwork commissioned by the Franciscans revealed this sensitivity toward non-verbal communication which could be found in Francis' Rules, thereby contributing much to the battle for doctrinal consistency in Catholic teaching.

\footnotetext{
${ }^{5}$ An interactive map of early Franciscan wood-panel art can be accessed at: https://tinyurl.com/ybzj7w9w (See Map 2). Malcolm Lambert, The Cathars (Oxford. UK; Malden, Mass., USA: Blackwell Publishers, 1998), 52.

${ }^{6}$ William Cook wrote an article that examines the impact of the Cathars on the Orte Dossal; and Bradley Franco discusses the heretics in his chapter on how Franciscan art was used and perceived in this period, including references to the Cathar. See William Cook, "The Orte Dossal: A Traditional and Innovative Life of St. Francis of Assisi.," Arte Medievale / Istituto Della Enciclopedia Italiana. 2 (1996): 41-47; Franco, "Functions of Franciscan Art."

${ }^{7}$ Francis et al., Francis and Clare, 122.
} 
I based my sample study on the wood-panel paintings from the earliest era of artwork produced or commissioned by the Order of Friars Minor, within the range of years 1235 - 1300. This places the latest examples within a decade of the decoration of the Upper Basilica of San Francesco in Assisi, completed between 1296 to 1304. This was the point in time when the visual and narrative canon of Francis' life is considered to have been finalized. ${ }^{8} \mathrm{I}$ focus only on panel paintings consisting of three distinct iconographic forms that were widespread in the first century of the order: simple icons of Francis, vita dossals which compound a central image of the saint with smaller narrative scenes of the saint's life, and images of Francis beneath a monumental crucifix. ${ }^{9}$ Each panel that is considered could have been seen reasonably well within a public setting rather than sized for private devotions. With these parameters in place, my sample consists of ten simple icon portraits, eight vita dossals, and ten crucifixes.

The first chapter of this dissertation will contextualize the Cathars, Francis, and the early community of the Friars Minor in their Italian setting. The second chapter offers a brief history of wood-panel paintings as an artistic medium and the meanings associated with this material. In the third chapter, I will analyze the simple icons of Francis to explore how he was presented to the thirteenth-century audience as an orthodox counterexample to the Cathars' Perfecti. ${ }^{10}$ The fourth chapter will discuss the vita dossals'

\footnotetext{
${ }^{8}$ William Cook, "Fraternal and Lay Images of St. Francis in the Thirteenth Century," in Popes, Teachers, and Canon Law in the Middle Ages, ed. James Ross Sweeney and Stanley Chodorow (Ithaca: Cornell University Press, 1989), 266; Franco, "Functions of Franciscan Art," 39, 43.

${ }^{9}$ Although the term dossal typically connotes a stationary decorative altarpiece or retable, I will argue that these painted panels were not permanently situated as the backing to an altar. The term, nevertheless, remains conventional.

${ }^{10}$ Ikon, or eikon, in Greek, means image. At their most basic, icons are figural representations of holy men and women. In Christian heritage, however, icons are not like modern portraits meant to display the physical likeness of a person. Rather, they represent his/her prototype or actual being, thus allowing the
} 
narrative depictions of Francis' life and posthumous miracles, focusing on themes of physicality, the Catholic doctrines of Incarnation and the Real Presence of Jesus in the Eucharist, and the divine origins of the natural world. The final chapter will examine the crucifixes that portray Francis at the base of Jesus' cross. Here I will look at the broader picture of evolution from the Christus Triumphans crucifix to the grisly and emotional realism of the Christus Patiens. The crucifixes at Perugia, Montefalco, Arezzo, and Spello will demonstrate this transition. I intend to elaborate on the capacity of an increasing naturalism of form to evoke an emotional response in the viewer and support orthodox religious belief as a counter to the Cathar movement.

\section{The State of the Field}

When surveying the literature for this study, three major groupings of scholarship needed to be explored. As the paintings form the core of my argument, publications pertaining to the artworks themselves took priority of research. These included general studies of Italian panel paintings, dipintura or dipinti in Italian, specifically Franciscan commissions, the materiality of the pieces, and the rare Cathar artifact. Secondly, the ever-shifting scholarship on the history and theology of the Cathars provided the necessary background for their contextualization. And finally, I have had to make selections from the wealth of Franciscan textual sources, both modern and primary. I then triangulated these three broad categories in order to examine where the Order of Friars Minor, the Cathars, and the artwork intersected and influenced one another.

\footnotetext{
viewer to venerate the saint through the materiality of the image. Representations of scripture or hagiography can also be considered icons. In this sense, we could describe all the images presented in this dissertation as icons, but for simplicity's sake, I will limit the use of the term to discussing only the isolated figure of Francis in tempera-painted wood panels.
} 


\section{Scholarship on the Artwork}

Interest in art related to the Catholic Church and the patronage of religious orders has seen major growth in recent years. ${ }^{11}$ The Franciscan order specifically, its branches combining to form the world's largest religious order, has received a good share of this attention. The art historical literature is in general agreement that a major shift in the presentation of Christian imagery in European art occurred at approximately the same time the Franciscan order was in its early stages of development in duecento Italy. ${ }^{12}$ The acknowledged leader in the study of images of Francis of Assisi is William Cook, a church historian whose research has spanned from the 1970s to the present. For his encyclopedic work, Images of St. Francis of Assisi: In Painting, Stone, and Glass: From the Earliest Images to Ca. 1320 in Italy: A Catalogue (1999), Cook traveled to view every known representation of the saint created during that early time period in the region in which the order originated. Cook also considers images that have dropped out of circulation for which there are photographs or only written descriptions remaining. While

\footnotetext{
${ }^{11}$ Examples of current interest are the recent museum exhibitions in Chicago, New York, and New Orleans: "Doctrine and Devotion: Art of the Religious Orders in the Spanish Andes, March 19, 2016-June 25, 2017," The Art Institute of Chicago, accessed June 10, 2020, https://www.artic.edu/exhibitions/2493/doctrine-and-devotion-art-of-the-religious-orders-in-the-spanishandes; "Heavenly Bodies: Fashion and the Catholic Imagination, May 10-October 8, 2018," The Metropolitan Museum of Art, accessed June 10, 2020, https://www.metmuseum.org/exhibitions/listings/2018/heavenly-bodies; New Orleans Art Museum, "Arte Sacre: Roman Catholic Art from Portuguese India, March 13th, 2020 - June 20th, 2021," New Orleans Museum of Art, accessed June 10, 2020, https://noma.org/exhibitions/arte-sacre-roman-catholic-art-fromportuguese-india/.

12 Three important recent studies which have addressed the influence of the Franciscans on this transitional period are Trinita Kennedy's Sanctity Pictured: The Art of the Dominican and Franciscan Orders in Renaissance Italy (Nashville: Frist Center for the Visual Arts, 2014), 2; Anne Derbes' Picturing the Passion in Late Medieval Italy: Narrative Painting, Franciscan Ideologies, and the Levant (Cambridge; New York: Cambridge University Press, 1996), 1-2, 11; and Bradley R. Franco's "The Functions of Franciscan Art," in The World of St. Francis of Assisi: Essays in Honor of William R. Cook, ed. Steven J. McMichael (Leiden: Brill, 2015), 39.
} 
Cook's study provides a catalogue raisonné of depictions of the saint, in this volume, he does not deeply analyze the artistic style or theological context of the full compositions, and since its publication he has identified additional works that he hopes to include in a new edition. ${ }^{13}$ In his brief systematic entry on each artwork, he speaks strictly of the image of Francis itself. Other articles and books by Cook have placed the works into context and analyzed them more fully. Particularly useful for this study have been his book The Art of the Franciscan Order in Italy, and the chapters "Fraternal and Lay Images of St. Francis in the Thirteenth Century," in Popes, Teachers, and Canon Law in the Middle Ages, "Representation of Post-Humous Miracles of St. Francis of Assisi," which was co-authored with Gregory Ahlquist; and "My Life with Francis," a look back on his own research that was published in a festschrift commemorating Cook's career. ${ }^{14}$ In addition to his more general studies of Franciscan art, Cook has written numerous articles on select works including the dossals in Orte, Florence, and Siena, and Margarito d' Arezzo's icons of the saint. ${ }^{15}$ William Cook is a church historian rather than an art historian, and he has sometimes had to rely on the testimony of the artworks' custodians

${ }^{13}$ William Cook, "My Life with Francis," in The World of St. Francis of Assisi: Essays in Honor of William R. Cook, ed. Bradley Franco and William Cook (Boston: Brill, 2015), 232.

${ }^{14}$ William Cook, Images of St. Francis of Assisi: In Painting, Stone, and Glass: From the Earliest Images to ca. 1320 in Italy : A Catalogue (Firenze; Perth [W.A.]: L.S. Olschki ; Dept. of Italian of the University of W. Australia, 1999); Cook, "Fraternal"; Cook, "My Life with Francis"; Gregory Ahlquist and William Cook, "The Representation of the Posthumous Miracles of St Francis of Assisi in ThirteenthCentury Italian Painting," Art of the Franciscan Order in Italy, 2005, 211-56.

15 William Cook, "Margarito d'Arezzo's Images of St Francis: A Different Approach to Chronology," Arte Cristiana / a Cura Della Scuola Beato Angelico e Dell'Istituto Di Storia Dell'Arte Dell'Università Cattolica, Associata al Centro d'Azione Liturgica e All'Unione Della Stampa Periodica Italiana., 1995, 83-90; William Cook, "The St. Francis Dossal in Siena: An Important Interpretation of the Life of Francis of Assisi.," Archivum Franciscanum Historicum., 1994, 3-20; Cook, "Orte Dossal”; William Cook, "New Sources, New Insights: The Bardi Dossal of the Life of St. Francis of Assisi," Studi Francescani. Firenze 93 (1996): 325-46. 
and curators for dating purposes. ${ }^{16} \mathrm{He}$ focused on the historical and spiritual context of the artwork, highlighting its ability to reveal the simplicity, poverty, and humility of the saint.

The historian Bradley Franco follows in the line of William Cook by addressing the iconography and functionality of the artwork. Franco's chapter, "The Pistoia Dossal and the Development of Franciscan Art" from the published proceedings of the First International Conference of Franciscan Studies, and his article "The Functions of Early Franciscan Art," were particularly helpful in the study of the mobility of the eight surviving thirteenth-century vita dossals, their use in preaching, and an analysis of the broader picture of Franciscan motivations and practice. ${ }^{17}$

Donal Cooper's book The Making of Assisi: The Pope, the Franciscans and the Painting of the Basilica, which he authored along with Janet Robson, and his numerous articles and chapters including "Preaching amidst Pictures: Visual Contexts for Sermons and Late Medieval Tuscany," "Experiencing Dominican and Franciscan Churches in Renaissance Italy," "Projecting Presence: The Monumental Cross in the Italian Church Interior," "In Loco Tutissimo e Firmissimo': The Tomb of St. Francis in History, Legend and Art," and "Franciscan Choir Enclosures and the Function of Double-Sided Altarpieces in Pre-Tridentine Umbria” have established Cooper as another leading scholar in the study of Franciscan art and medieval optic theories. ${ }^{18}$ Other authors who

\footnotetext{
${ }^{16}$ Cook, "My Life with Francis," 228.

${ }^{17}$ Franco, "Functions of Franciscan Art," 44.

${ }^{18}$ Donal Cooper, "Preaching Amidst Pictures: Visual Contexts for Sermons and Late Medieval Tuscany," in Optics, Ethics, and Art in the Thirteenth and Fourteenth Centuries: Looking into Peter of Limoges's Moral Treatise on the Eye (Toronto, Ontario,: Pontifical Institute of Medieval Studies, 2018), 29-45; Donal Cooper, "Experiencing Dominican and Franciscan Churches in Renaissance Italy," in Sanctity Pictured: The Art of the Dominican and Franciscan Orders in Renaissance Italy, ed. Trinita
} 
have contributed to my understanding of optical research in this field include Herbert Kessler, Jean Givens, Madeleine Caviness, and Michael Camille.

Elvio Lunghi is considered a preeminent scholar of Franciscan art. His work, mainly in Italian, focuses on the earliest textual evidence of the Franciscan order in relationship to its art. He recognizes the impact of the friars' influence stating, “...the spread of the Franciscan order wrote an important chapter in the history of sacred art in Europe, contributing toward the end of the Middle Ages to the spread of new iconographical models and a different use of images in the manifestations of individual and communal devotion." ${ }^{19}$ Lunghi makes clear that Francis is not the direct cause of the proliferation of art, but rather the Order of Friars Minor is responsible for its development.

The museum curators I met in Italy often shared with me books regarding their local collections and broader exhibitions which featured their dossals, icons, and crucifixes. These included catalogues from Il Museo Nazionale d'Arte Medievale e Moderna in Arezzo, the Pinocoteca Comunale of Castiglion Fiorentino, and the city museums of Montefalco, Gualdo Tadino, and Pistoia. An exhibition of Franciscan art held at the Academy in Florence showcased several of the artifacts under study with an

Kennedy, 2014; Kennedy, Cooper, Flora, Neff, Robson, et al., Sanctity Pictured; Donal Cooper and Janet Robson, The Making of Assisi: The Pope, the Franciscans and the Painting of the Basilica (New Haven: Yale University Press, 2013); Donal Cooper, "Projecting Presence: The Monumental Cross in the Italian Church Interior.," Presence / Ed. by Robert Maniura and Rupert Sheperd., 2006, 47-69; Donal Cooper, “'In Loco Tutissimo e Firmissimo': The Tomb of St. Francis in History, Legend and Art.," Art of the Franciscan Order in Italy / Ed. by William R. Cook., 2005, 1-37; Donal Cooper, Warburg Institute, and Courtauld Institute of Art, Franciscan Choir Enclosures and the Function of Double-Sided Altarpieces in Pre-Tridentine Umbria. (London: Warburg Institute, 2001).

${ }^{19}$ Elvio Lunghi, "Francis of Assisi in Prayer Before the Crucifix in the Accounts of the First Biographers," Studies in the History of Art / Publ. by the National Gallery of Art, Washington., 2002, 341. 
in-depth catalogue published in $2015 .^{20}$ Abbondio Zuppante, director of the Museo d'Arte Sacra di Orte, was kind enough to share his research manuscript, currently in press in the summer of 2019.

In her powerfully argued book Picturing the Passion in Late Medieval Italy: Narrative Painting, Franciscan Ideologies, and the Levant (1996), Anne Derbes explores the reasons behind the significant transition that occurred in the portrayal of sacred subject matter. While her focus varies from that of this dissertation, she supplies a thought-provoking rationale for the expansion of the Passion narrative depicted on medieval altarpieces in the thirteenth and fourteenth centuries especially under the patronage of the Franciscans. Derbes argues, “A growing empathy for Christ's suffering during the passion emerged as early as the late eleventh century and gained momentum in the twelfth." 21 She explores the reasons behind these significant transitions, using the historical backdrop of images produced in Byzantium and northern Europe and the patronage of both Franciscans and others. ${ }^{22}$ Along with Amy Neff, Derbes continues to

${ }^{20}$ Lionello Giorgio Boccia et al., Arte nell'Aretino: recuperi e restauri dal 1968 al 1974 : Arezzo, San Francesco, 14 dicembre 1974-2 febbraio 1975 (Firenze: Edam, 1974); Paolo Torriti, ed., Al tempo del beato Mansueto: Castiglion Fiorentino e il suo territorio nel Duecento (Firenze: Scramasax, 2006); Bruno Toscano, Museo Comunale di San Francesco a Montefalco (Perugia: Electa, Ed. Umbri Assoc., 1990); Pierluigi De Vecchi et al., Museo Civico di Gualdo Tadino. decorazione murale, dipinti, materiali lapidei, sculture, arredo civile ed ecclesiastico, tessuti 1, 1, (Perugia: Electa Editori Umbri Associati, 2000); Pistoia (Italy) et al., Museo civico di Pistoia: catalogo delle collezioni (Firenze: La nuova Italia, 1982); Angelo Tartuferi, Francesco D'Arelli, and Italie Museo dell'Accademia Firenze, L'Arte di Francesco: Capolavori d'Arte Italiana e Terre d'Asia dal XIII al XV secolo : Firenze, Galleria dell'Accademia, 31 Marzo - 11 Ottobre 2015 (Firenze: Giunti, 2015).

${ }^{21}$ Anne Derbes, Picturing the Passion in Late Medieval Italy: Narrative Painting, Franciscan Ideologies, and the Levant (Cambridge; New York: Cambridge University Press, 1996), 17.

22 Derbes, Picturing the Passion, 2-3, 11, 17. 
examine the Franciscans' Eastern ties in her chapter for the Metropolitan Museum of Art's exhibition catalogue Byzantium: Faith and Power (1261-1557). ${ }^{23}$

In a study that parallels my own interests, the Franciscan historian and theologian Thomas Herbst's master's thesis, “The Humanization of Christ in the Central Italian Panel Crucifixes of the Twelfth and Thirteenth-Centuries Reflected in the Development of Franciscan Christology," provides a thorough analysis of the development of the friars' painted panel crucifixes in correlation to contemporary Franciscan Christology. ${ }^{24}$ A synthesis of this work was later published as "Franciscan Christology in the Development of the Iconography of the Passion," in The Cord: A Franciscan Spiritual Review. $^{25}$

A collection of essays edited by Trinita Kennedy: Sanctity Pictured: Art of the Dominican and Franciscan Orders (2014) serves as an excellent resource on the materiality of panel painting and the uses of the monumental images inside church architecture. In particular, Amy Neff's important essay, "Painting, Devotion, and the Franciscans," elaborates on the theology that was fundamental to the creation of Franciscan artwork. She sees their use of images as having a dual role: an exterior purpose to interact with and educate the viewer; and an interior purpose to stimulate

\footnotetext{
${ }^{23}$ Anne Derbes and Amy Neff, "Italy, the Mendicant Orders, and the Byzantine Sphere," in Byzantium: Faith and Power (1261-1557), ed. Helen C Evans (New Haven: Yale University Press, 2004).

${ }^{24}$ Thomas Herbst, OFM, "The Humanization of Christ in the Central Italian Panel Crucifixes of the Twelfth and Thirteenth-Centuries Reflected in the Development of Franciscan Christology" (Masters Thesis, Berkeley, California, Franciscan School of Theology, Graduate Theological Union, 1989).

${ }^{25}$ The Cord is now published as Franciscan Connections - The Cord: A Spiritual Review by Franciscan Institute Publications of St. Bonaventure University. Thomas Herbst, OFM, "Franciscan Christology in the Development of the Iconography of the Passion," The Cord: A Franciscan Spiritual Review 59, no. 3 (September 2009).
} 
reflection and spiritual growth. ${ }^{26}$ While Neff does not address the effect of the Franciscans' reaction to heresy, she points the reader toward the influence of the brothers' devotion to Catholic orthodoxy on the works they commissioned.

Moving to more general art historical sources that have been useful for my research, Sara Lipton's article, “'The Sweet Lean of His Head:' Writing about Looking at the Crucifix in the High Middle Ages," concentrates on the medieval act of viewing crucifixes beginning approximately a century prior to Francis. While her focus lies in France and Belgium, Lipton's wide-ranging research provides a map to trace the roots of Franciscan ideas further back to Benedictine and Cistercian influences. In addition to the liturgical framework, Lipton situates her work within the dialectical approach of competing theologies. While she mentions the crosses as a response to heresy in general, this article does not broach the subject of the Cathars specifically.

David Talbot Rice presents a fascinating guide to the relationship between Byzantine works and duecento Italian panel painting in his book Byzantine Painting: The Last Phase. Although Rice's 1968 volume is feeling the effects of age, it proposes a valuable connection between xItalian art and eastern exemplars. Similarly Hans Belting investigates the connection between Byzantine and Italian Gothic art in his seminal volume Likeness and Presence: a History of the Image before the Era of Art. Throughout this tome, Belting not only explains the material nature of artifacts and their historical settings, but he also exposes the philosophical motivation implicit in the artwork. Belting offers extensive research on the art of the Franciscans; however the religious order's response to the Cathars does not feature in his work.

\footnotetext{
${ }^{26}$ Neff, "Painting, Devotion, and the Franciscans," 42.
} 
In his much-debated book, The Sexuality of Christ in Renaissance Art and in Modern Oblivion (1983), Leo Steinberg explores how art has wrestled with the notion of Jesus' physical form, specifically his sexuality, as fully human. While Steinberg avoids mention of Catharism, his theories will lend a certain specificity to my argument. Caroline Walker Bynum famously presented a response to Steinberg, which I will also consider. The two authors may actually argue in parallel with only the definition of sexuality dividing them. Their focus on sex-both as the procreative act and as genderwas a strongly contested subject in the belief system of the Cathars and played a pivotal role in Christological arguments of the day.

I drew primarily from four sources for my study of the materiality of the dipintura panels. The first is Umberto Baldini and Ornella Casazza's book, The Crucifix by Cimabue, which studies the restoration of the crucifix of the Florentine church of Santa Croce after the 1966 flood of the Arno River. The photographic record of the multiple layers that form both the geometric schematics and the construction of the painted cross remains indispensable for the analysis of the material. The historical work, The Craftsman's Handbook, by the fourteenth-century artist Cennino d'Andrea Cennini also provides insight into the traditional process of wood-panel painting. David Bomford's introduction to a publication resulting from a 1995 symposium at the J. Paul Getty Museum offers his extensive knowledge on the construction and conservation of panel paintings. And no study of this field can neglect Edward B. Garrison's foundational work Index of Italian Panel Painting that has been reissued several times since its 1949 debut.

Finally, research connecting environmental issues with Franciscan theology facilitated a deeper awareness of the friars' relationship with nature and the iconography 
and materiality of their artwork. Lynn White's “The Historical Roots of Our Ecologic Crisis," Jessica Rezunyk's “Science and Nature in the Medieval Ecological Imagination," and L.J. Kiser’s “Animal Economies: The Lives of St. Francis in Their Medieval Contexts" and "The Garden of St. Francis: Plants, Landscape, and Economy in Thirteenth-Century Italy," all provided challenging and fruitful insights.

\section{Scholarship on the Cathars}

The visual and material remains of the Cathar communities are considerably more elusive than that of the Franciscans, and few authors have explored these artifacts. Anne Brenon's "Cathars and the Representation of the Divine: Christians of the Invisible," in Women Preachers and Prophets through Two Millennia of Christianity, provides an overview of three Cathar manuscripts that survived the inquisitional purge. Scholarly work on the history and theology of the group, however, provides a strong if at times controversial backdrop.

Walter Wakefield's scholarship is considered foundational for modern scholars of heresy. ${ }^{27}$ With his mid-twentieth century dissertation The Treatise against Heretics of James Capelli; a Study of Medieval Writing and Preaching against Catharan Heresy, and the book Heresies of the High Middle Ages, along with co-author Austin P. Evans, Wakefield explores the range of contemporary heresies from the eleventh to the thirteenth centuries, providing translations of primary sources. Wakefield presents the customs and beliefs of not only the Cathars but other contemporary heterodoxies. In the latter text, however, Wakefield purposefully avoids a full discussion of the efforts of the new

\footnotetext{
${ }^{27}$ Numerous authors included in the publication based on the 2013 Conference at University College London, that wrestle with modern debates surrounding the Cathars cite Walter Wakefield extensively. Antonio C. Sennis, Cathars in Question (York: York Medieval Press, 2018).
} 
mendicant orders (the Franciscans and the Dominicans). He calls these religious brothers "effective agents against heresy not only because of their preaching and because they furnished inquisitors for the new tribunal of the Inquisition, but even more because they helped to satisfy within the Church the insistent popular pressure for piety and morality in daily life." ${ }^{28}$ While acknowledging their important work to eradicate vice and heresy and teach orthodox practice, he allows other scholars to explain the full import of these orders.

Although it is an older work, John Stephens' 1972 article "Heresy in Medieval and Renaissance Florence," provides an investigation of Cathars within a specific Italian context. Here Stephens follows the Cathars (often labeled Patarenes) and the Fraticelli, also known as the Spiritual Franciscans, whose beliefs served as the dominant heterodoxies of the twelfth to fourteenth centuries in Florence. The article focuses on the political and legislative milieu of a community that offers waxing and waning support of papal authority, independent inquisitional powers, and the heretics who played a surprisingly active role in the society of Florence, which Stephens calls "the centre of one of the Italian Cathar churches." ${ }^{29}$ Stephens' article follows the path of the Cathars from their origins in the Balkans, through Italy until their decline, which he locates in the early fourteenth century. The article also briefly touches on other sects active in and around Florence including the Waldensians, Beguines, Apostoli, followers of the Dominican visionary friar Girolamo Savonarola, and later Protestant Christianities.

\footnotetext{
${ }^{28}$ Walter L. Wakefield and Austin P. Evans, Heresies of the High Middle Ages, Records of Civilization, Sources and Studies, no. 81 (New York: Columbia University Press, 1969), 37.

${ }^{29}$ John N Stephens, "Heresy in Medieval and Renaissance Florence," Past \& Present, no. 54 (1972): 59.
} 
The French historian Emmanuel Le Roy Ladurie published his microhistory Montaillou: The Promised Land of Error originally in 1975. In it, Ladurie details the life of Languedoc villagers from 1294 to 1324, based on personal accounts given in interviews conducted by the Dominican inquisitor Jacques Fournier, later Pope Benedict XII (1285-1342, r. 1334-1342). The book is divided into two parts: "The Ecology of Montaillou: the house and the shepherd" which describes specific villagers in relation to their households and occupations; and "An archaeology of Montaillou: from body language to myth" which enumerates the cultural mores surrounding the body and sex, marriage and child-bearing/rearing, death, cultural and social exchange, magic, religious practices, economy and labor, and moral codes. Montaillou is considered by scholars to be the most detailed account of specifically named people who adhered to the Cathar doctrine. Their story relays the circumstances of the remnants of the heterodox Christians and is a rare view of medieval peasant life from a first-person perspective. The inquisitional register provides the accounts of 114 people in ninety-eight cases, mostly peasants, craftspeople, and small shopkeepers. ${ }^{30}$ Ladurie's text also provides details of the community's material life, sparse as they may be.

An early source for my scholarship on the heterodoxy is The Cathars by Malcolm Lambert who made substantial use of both Wakefield's and Ladurie's research. Lambert

\footnotetext{
${ }^{30}$ Ladurie's book encountered some criticism in its early life, particularly in regard to the accuracy of its translation of inquisitional records and Ladurie' selection of anecdotes to appeal to a popular audience. Nevertheless, it remains a highly regarded source of information on the lifestyle of medieval heretics. Montaillou is cited multiple times in the publication based on the 2013 Conference at University College London, which will be discussed later. Emmanuel Le Roy Ladurie, Montaillou: The Promised Land of Error (New York: G. Braziller, 1978), xiv; David Herlihy, 'Book Review: 'Montaillou': Cathars and Catholics in a French Village, 1294-1324," Social History 4, no. 3 (1979): 517-20; P. S. Lewis, review of Review of Montaillou, Village Occitan, de 1294 à 1324, by Emmanuel Le Roy Ladurie, The English Historical Review 92, no. 363 (1977): 371-73; Sennis, Cathars in Question.
} 
supplied the first extensive English study of Catharism in 1998. He makes the case that the Cathars' history can be validly reconstructed from the few extant writings that explain the Cathars' mission in their own words.

A niggling of doubt began to creep into the question of the Cathar heresy in the 1980s and 1990s, especially among the French and Italian scholars. In his chapter, “Goodbye to Catharism?” Peter Biller discusses the work of French medieval historian Monique Zerner and her search for forgeries among the inquisition records on which Cathar research often is based. ${ }^{31}$ In this same line of research, Lorenzo Paolini, in his chapter "Italian Catharism and Written Culture," laments that:

In recent decades Italian historians have tended to avoid the theme of Catharism and culture, partly because the historiographical trend has been more towards looking at heretics as people, living in a tangible, social setting, an approach which has favoured the use of inquisitors' trials with their 'daily life' material. A further explanation is the continuing appeal of ... [the view that] Cathars could be stimuli or vehicles of thought at a popular level, but they were not a creative source, not able to assimilate and rework ideas or to exercise an influence on medieval culture. ${ }^{32}$

Paolini argues against this sentiment, holding that the Cathars were not "marginal" but rather were a vibrant and influential part of the growing cities of Lombardy. ${ }^{33}$ While he focuses on evidence from northern Italy, in this dissertation I will look instead to the regions of Tuscany, Umbria, and Lazio. While these regions provide less robust textual

\footnotetext{
${ }^{31}$ Peter Biller, "Goodbye to Catharism?," in Cathars in Question, ed. Antonio Sennis (Woodbridge, Suffolk: York Medieval Press, 2016), 280-81.

${ }^{32}$ Lorenzo Paolini, "Italian Catharism and Written Culture," in Heresy and Literacy, 1000-1530, ed. Peter Biller and Anne Hudson (Cambridge [England]; New York, NY, USA: Cambridge University Press, 1996), 83.

${ }^{33}$ Paolini, "Italian Catharism," 83.
} 
evidence of Cathar communities, I argue that the abundant artwork of the Franciscans responds to the presence of heterodoxy. ${ }^{34}$

As suggested, the doubts simmering in the late twentieth century have come to a head in a strongly contested debate about the very existence of the Cathars. The main points of contention swirl within the timeframe immediately prior to and simultaneous with this dissertation's chronological focus_-during the time of the early Franciscan Order's response to the heresy. I will briefly summarize the current state of the argument. A conference held in April 2013, at University College London, explored the evidence surrounding whether dualist belief existed as a structured organization in Europe prior to the thirteenth century. Peter Biller represents scholars who offer evidence for the presence of heretics named as Cathars in both Languedoc and Italy from at least the 1140s. Opposing them are Robert I. Moore and Mark Gregory Pegg, who claim that the supposed heretics, at least in Languedoc, are the production and/or projection of medieval inquisitional forces set to work by the Catholic Church for political purposes. The claims of Biller, Moore, and Pegg have been presented separately in several books, essays, and articles; ${ }^{35}$ and together in the 2013 conference proceedings, published as Cathars in

\footnotetext{
${ }^{34}$ While Catharism was prevalent in Milan and the north, the Dominican order handled inquisition in that region. Therefore, I focused on the artwork from regions where the Franciscans were in authority: Umbria, Tuscany, and Lazio. Nevertheless, some of the best contemporary textual sources come from the northern locales. See also Wakefield and Evans, Heresies, 159-60.

${ }^{35}$ Peter Biller, "Cathars and the Material World," in God's Bounty?: The Churches and the Natural World, ed. Peter Clarke and Tony Claydon (Woodbridge, Suffolk, UK; Rochester, NY: Ecclesiastical History Society; Boydell \& Brewer, 2010); Peter Biller and Alastair Minnis, Medieval Theology and the Natural Body (Suffolk; Rochester, N.Y.: York Medieval Press, 1997); Robert I. Moore, The War on Heresy (Erscheinungsort nicht ermittelbar: Belknap Harvard, 2014); R. I Moore, The Formation of a Persecuting Society: Power and Deviance in Western Europe, 950-1250 (Oxford: Basil Blackwell, 1987); Mark Gregory Pegg, "Albigenses in the Antipodes: An Australian and the Cathars," Journal of Religious History 35, no. 4 (December 2011): 577-600, https://doi.org/10.1111/j.14679809.2011.01143.x; Mark Gregory Pegg, The Corruption of Angels: The Great Inquisition of 1245-1246 (Princeton, NJ: Princeton University Press, 2001).
} 
Question, in which they attack one other's views and methodologies within the same volume.

Moore's introductory chapter to the conference proceedings attempts to summarize the findings of the conference. ${ }^{36}$ Moore provides an overview of Cathar historiography, beginning with Charles Schmidt's first study of primary sources regarding the Cathars, entitled Histoire et doctrines de la secte des cathares ou albigeouis, published in 1849. According to Moore, Schmidt determined that "the Cathars, with whom the inquisitorial treatises and records of the thirteenth century were chiefly concerned, were part of a single movement with the Bogomils of the Byzantine world, sharing a common body of doctrine, ritual, myth, and organization." ${ }^{37}$ While this view went unquestioned until the middle part of the twentieth century and is still held by many scholars today, Moore asserts that "Catharism" is rather a conflation of many people and groups who held heterodox doctrine during the twelfth to fourteenth centuries - a combined entity.

The core question of the modern debate asks at what point in time this medieval version of dualism — a belief in two transcendent deities, one good and one evil—began to be held by an organized sect, whether by the 1140s as some evidence suggests or not until the mid-thirteenth century. Moore explains that Schmidt may have misinterpreted as dualism the influences by early reformers who were living out a charism of apostolic

\footnotetext{
${ }^{36}$ Ideas from this section are drawn from R.I. Moore, "Principles at Stake: The Debate of April 2013 in Retrospect," in Cathars in Question, ed. Antonio Sennis (Woodbridge, Suffolk: York Medieval Press, 2016), 257-60.

${ }^{37}$ Moore, "Principles at Stake," 258-59.
} 
poverty, a theory first proposed by Raffaello Morgehn in $1944 .{ }^{38}$ According to Moore, several established facts were agreed upon at the 2013 conference. First, the fact that that prior to the Albigensian crusade in Languedoc (1209-1229), "clear evidence of the presence of organized dualism in Europe... is very slight at best, and that after 1250 it is both abundant and substantial. ${ }^{\prime 39}$ It is also generally agreed upon that in the second half of the thirteenth century, there existed in Italy a coordinated group holding dualist beliefs. This group was linked to heretics in Languedoc by shared ritual and doctrine. ${ }^{40}$ The Italian sect also claimed the Balkan dualists as its ancestry. They were known intermittently by the appellation of "Cathar." However, the manner in which this sect developed has not been confirmed by sufficient evidence, says Moore. ${ }^{41}$

Moore says there is inadequate evidence for the Cathars' historical roots prior to the1250s - that heretical groups may have believed they had ancient roots, but none can be established by modern scholars. Moore admits that he has no alternative theory of the Cathars' rising at this time. He offers only some ideas for their origin and development at about the mid-point of the thirteenth century: Moore believes an increasingly systematic and effective persecution forced the growth of a secretive organization with more committed and loyal members. This caused the membership to create "elaborate group

\footnotetext{
${ }^{38} \mathrm{~A}$ charism is defined as a specific gift of spirit or grace given to a particular person or group which they are to use for the benefit of other people.

${ }^{39}$ Moore, "Principles at Stake," 257.

${ }^{40}$ It is theorized that some Languedocian Cathars had relocated to the Italian region during the Albigensian strife.

${ }^{41}$ Moore acknowledges that the thirteenth century lies just beyond his academic expertise. Moore, "Principles at Stake," 257-258.
} 
identities, memories, and history, or to accelerate and intensify whatever tendencies in those directions already existed among them. ${ }^{42}$

In the same conference proceedings, Mark Gregory Pegg presented his stance in “The Paradigm of Catharism; or, the Historians' Illusion.” His position denying the very existence of the Cathar heresy is unequivocal, as he says, "Catharism was neither a Balkan heresy, a construct of the persecuting society, or, for that matter, even a medieval phenomenon, as it has never existed, except as an enduring invention of late nineteenthcentury scholars of religion and history. ${ }^{, 43}$ Pegg believes that many disparate heterodox beliefs have been lumped together as Catharism; a practice that has led to a false picture of a monolithic heresy. ${ }^{44}$ Pegg lays the blame for this scholarly failure at the feet of Arno Borst and his 1953 study Die Katharer. Pegg claims that Borst attributed any eleventh to the thirteenth century textual reference made to “'Manicheans', 'Arians', 'Patarenes', 'the heretics', or accusation of dualism, however vague or inconsistent, was a reference to Catharism. ${ }^{45}$ Borst and subsequent scholars proceeded to study the Cathars as a distinct group.

While Pegg rejects the monolithic term Cathar, he recognizes that there was indeed a heterodox movement to which orthodox preachers and inquisitors were responding. Pegg argues that the disparate twelfth- and thirteenth-century practitioners of

${ }^{42}$ Moore, "Principles at Stake," 270-71.

${ }^{43}$ Pegg, "The Paradigm of Catharism; or, The Historians' Illusion," in Cathars in Question, ed. Antonio Sennis (Woodbridge, Suffolk: York Medieval Press, 2016), 21.

${ }^{44}$ Pegg, "Paradigm of Catharism," 29.

${ }^{45}$ Pegg, "Paradigm of Catharism," 29. 
heterodoxy did not consider themselves to be a distinct group until the medieval inquisitional powers and civil authorities identified them all together into an assemblage known as "good men." These incongruent, persecuted peoples became fugitive particularly during the Albigensian Crusade and following the Treaty of Paris that officially ended the conflict in 1229 . The remnants of the heterodox movement re-formed as an entity that opposed the orthodox church, adopting a history and identity forged by inquisitional supposition. ${ }^{46}$ Pegg blames the persecutors for creating the heretics: "What transformed these individuals into heretics," he says, "What turned the accusation into actuality, was the violence of the Albigensian Crusade and the persecution of the early inquisitors. ${ }^{.47}$

In this chapter, Pegg tears apart the positions of other historians without adequately presenting or defending his own. He rejects the extant texts that have been held as evidence of Catharism in a footnote with no justification for their failing his proof-test. He says,

... there is the inconvenient fact that no theological books written by Cathars have survived, apart from alleged extracts in the summae of Dominican inquisitors or a few ambiguous texts from the late thirteenth century. This bothersome technicality is brushed aside by saying the theological books of the Cathars are lost. Destroyed or missing documents are common for the medievalist, and sometimes what has disappeared did once exist. This is not the case with the lost books of the Cathars, which are as much a fantasy as Catharism itself. ${ }^{48}$

These texts, as listed by Pegg in a footnote, are:

\footnotetext{
${ }^{46}$ Moore, "Principles at Stake," 261.

${ }^{47}$ Pegg, "Paradigm of Catharism," 38.

${ }^{48}$ Quote and the following list of texts are taken from Pegg, "Paradigm of Catharism," 36-37.
} 
- The Occitan New Testament and Ritual

- A Latin Ritual

- 'The Book of the Two Principles

- A 'Gloss on the Lord's Prayer' and an 'Apologia for the Church of God' found in Trinity College Dublin

- A 'Cathar' treatise in the treatise of Durand of Huesca

- Extracts from a lost book of the 'Cathar' Tetricus quoted by Moneta of Cremona in his Adversus Catharos et Valdenses libri quinque

- The lost 'Cathar' Stella referenced by Salvo Burci in his Liber supra stella While the authorship of every document attributed to the Cathars cannot be verified, this vast amount of evidence, utilized by scholars for decades, should not be ignored outright. My own conclusions regarding whether the Cathars existed as not only a factual, but also an influential, entity parallel those of the historian Peter Biller more closely. Biller's contribution to the 2013 conference proceedings is entitled "Goodbye to Catharism?" In it, Biller presents his criticism of Pegg's Corruption of Angels and Moore's War on Heresy, which is heavily based on the work of Pegg. Systematically analyzing both works, he indicates when evidence for the Cathars' existence and character was misinterpreted, neglected, or willfully omitted by Pegg and Moore. Point by point, Biller convincingly identifies the inaccuracies and deficiencies of Moore's and Pegg's scholarship. Comparing their sources to the breadth of inquisitional testimony analyzed by Monique Zerner's critical group, Biller claims that Pegg, in addition to relying on encyclopedia articles, uses only "one set of depositions contained in just one manuscript" and Moore relies on only "about $0.01 \%$ of the extant inquisition records of 
this region [Languedoc]." ${ }^{49}$ Further examples of Biller's disdain include Biller's rejection of Pegg's claim that the term Perfectus was not used until seventeenth-century copyists invented it. Rather, Biller provides evidence for the word "in legislation about the repression of heresy in Languedoc, in inquisitor's formulae and in Bernard Gui's sentences." ${ }^{50}$ Defending Arno Borst's Die Katharer from Pegg's attacks, Biller notes that Borst's study provides, in an appendix, an etymology for the numerous designations either applied to heretics or adopted for themselves. A final example of Biller's criticism of the idea that the Cathars are a fabrication deals with Moore's late dating of the text Vision of Isaiah. This manuscript, which provides a description of dualistic rituals, was used by both the Bulgarian and Italian Cathars and is related to a heretic known to be active between 1190 and 1240 . However, Moore delegitimizes the manuscript by relying on only an extant copy dated to the mid-thirteenth century. ${ }^{51}$ Biller's frustration with this controversy of whether the Cathars actually exist comes through in his conclusion. Discussing the amount of time and effort deployed in the recent controversy, Biller asserts, "Such work should not have to be done. If they were not busy with all this clearup work, scholars would be free to devote their energy to investigating the interesting questions." 52

My own research lies on the edge of this modern debate. The harshest divisions in the controversy deal with the Languedoc region of modern France and the period

\footnotetext{
${ }^{49}$ Biller, "Goodbye to Catharism?" 280-81.

${ }^{50}$ Biller, "Goodbye to Catharism?" 284.

${ }^{51}$ Biller, "Goodbye to Catharism?” 275, 290.

52 Biller, “Goodbye to Catharism?" 304.
} 
between 1140-1250. My study is rooted in Italy with the artwork under consideration produced between 1235-1300. Even Pegg acknowledges evidence for a growing dualist sect in Europe after the Peace of Paris in 1229, just three years following the death of Francis. All sides also agree that in Italy, at least after 1250, numerous heterodox, specifically dualist, communities had been established to the point of forming a hierarchical structure led by bishops. The nomenclature "Cathar" was used to describe many of these sects in contemporary polemical and inquisitional writing. ${ }^{53}$ These events coincided with the rapid growth or the Order of Friars Minor and its increasing production of artworks depicting their founder Francis.

Another current author, seemingly respected by both sides of the modern debate, is Carole Lansing with her microhistory of Cathar activity in Orvieto. ${ }^{54}$ In her book, Power and Purity: Cathar Heresy in Medieval Italy, Lansing disputes that the Cathar practitioners were organized or that their beliefs were structured and uniform. They were unequivocally present, however, according to Lansing; and she offers numerous examples of both their writing and their activity. Lansing identifies four different kinds of primary sources that contribute to the evidence for the Cathar heresy. Though few in number, texts written by and for Cathar adherents make up the first category. These include the Liber de Duobus Principiis (Book of Two Principles), composed by a thirteenth-century Italian, the Vision of Isaiah, and the Cathar Star, all of which were disseminated throughout Europe. Additionally, there exist brief and partial credal

\footnotetext{
${ }^{53}$ Moore, "Principles at Stake," 258, 270.

${ }^{54}$ Information in this section is based on Carol Lansing, Power and Purity: Cathar Heresy in Medieval Italy (New York: Oxford University Press, 2001), 17-21, 82.
} 
statements given by Cathar leaders and preachers. Secondly are texts written to explain and battle the heresy for a Catholic audience such as the writings of the Franciscan apologist James Capelli and the Dominican friar and converted heretic, Ranieri Sacconi. Lansing's own study which focuses on the town of Orvieto highlights the third kind of primary source: hagiographical texts that offer the legends and miracles of both Catholic and Cathar holy figures. Finally, and most well-known, are the inquisitional depositions, testimonies, and sentences of Cathars. These have been filtered through Catholic clerks who transcribed them from the vernacular language of the accused into Latin for the official church and civic record. While there are some trial histories in Florence and Bologna, the records in Italy are incomplete in comparison to those of France. Lansing's work provides a modern example of a localized history in the legacy of Montaillou. The geographic focus of her work, Orvieto, lies just fifty kilometers northwest of Orte, providing a useful analogue for the Franciscan locales.

It is important to note one other current of modern Cathar publications - that of popular culture. The historic Cathar movement has gained admiration from modern gnostic and occultist groups. Some of these authors attribute both Francis of Assisi's lineage and belief-system largely to the Cathars. For example, in the book S. Francesco: le verità nascoste : l'amore per Chiara, i Templari, $i$ Sufi, $i$ Catari, tutti i misteri di Assisi, Gian Marco Bragadin presents a collection of esoterisms regarding Francis as a lost history that has been suppressed by the Roman Catholic Church. However, Bragadin's work is unsupported by scholarly research, lacking citations throughout the 
text. ${ }^{55}$ Popular theories such as Bragadin's regarding Francis' connection to the Cathars persist as rumor. When I asked an historian who also volunteers at a church in Assisi about an association between Francis and the Cathars, he expressed hesitation. He lowered his voice and said, "We know Francis' mother was French, and there may have been some relationship there. But the friars do not discuss that."

\section{Scholarship on the Franciscans}

The bulk of the theological underpinnings for my argument rest on the primary sources written by the mendicant friars themselves. While in most of their texts they do not explicitly name the Cathar heresy, their message focuses on the doctrinal orthodoxy that they contend is the correct and necessary path to salvation. These thirteenth-century texts can be divided into two further categories: the development of the Order of Friars Minor and the preaching of the brothers in favor of orthodox Catholic beliefs and against heretical doctrine. This literature will enable us to consider the interfaces which took place among the friars, the Catholic faithful, the Cathar adherents, and most importantly for this study, the artwork.

The founder of the order, Francis of Assisi (1181/2-1226), left behind thirty-eight brief works including letters to religious and secular authorities, admonitions to his brothers, prayers, canonical hours, and mystical songs. Francis' texts are taken mainly from the first and second versions of his Rule for the brothers' way of life (1209 or 1210, and 1223 respectively), as well as his letters and prayers, penned as an itinerant preacher between 1209 and his death in 1226. I used mainly the versions published by Regis

\footnotetext{
${ }^{55}$ Gian Marco Bragadin, S. Francesco: Le Verità Nascoste : l'Amore per Chiara, i Templari, $i$ Sufi, i Catari, Tutti i Misteri di Assisi (Torino: Melchisedek, 2016).
} 
Armstrong as St. Francis of Assisi: Writings for a Gospel Life; St. Francis of Assisi:

Writings and Early Biographies, English Omnibus of the Sources of the Life of St.

Francis, edited by Marion A. Habig, and the editions made available digitally through the Commission on the Franciscan Intellectual Tradition. ${ }^{56}$

The first three biographical texts on Francis were written by Thomas of Celano, a friar personally acquainted with Francis who gathered eye-witness accounts of the saint and his posthumous miracles. I have chosen the 2004 edition entitled The Francis Trilogy of Thomas of Celano: The Life of Saint Frances, the Remembrance of the Desire of a Soul, the Treatise on the Miracles of Saint Francis, that was translated by Regis Armstrong, Wayne Hellmann, and William Short. Fr. Hellmann provided my first introduction to the writings of the early Franciscans during my undergraduate years at Saint Louis University, and he graciously served as a sounding board regarding several points of my dissertation. Another vita written by Thomas of Celano during the period between the first two editions has only recently been found. It was translated and published by Jacques Dalarun and Timothy J. Johnson as the Rediscovered Life of St. Francis of Assisi. ${ }^{57}$

Bonaventure of Bagnoregio (1217-1274) became the most prolific author of the early Franciscan order. A theologian and professor at the University of Paris, he was ordained as the Bishop of Albano and served as an adviser to Pope Gregory X (r. 1276-

${ }^{56}$ Regis J. Armstrong and Francis of Assisi, St. Francis of Assisi: Writings for a Gospel Life, Crossroad Spiritual Legacy Series (New York: Crossroad, 1994), 26; Francis of Assisi, St. Francis of Assisi: Writings and Early Biographies: English Omnibus of the Sources for the Life of St. Francis, ed. Marion A Habig (Chicago: Franciscan Herald Press, 1973); "Franciscan Intellectual Tradition," Franciscan Intellectual Tradition, accessed June 10, 2020, https://franciscantradition.org/.

57 Thomas of Celano and Jacques Dalarun, The Rediscovered Life of St. Francis of Assisi, trans. Timothy J. Johnson (St. Bonaventure University: Franciscan Institute Publications, 2016). 
1271) and the Second Council of Lyon. He strongly influenced the Franciscan order when he was named its seventh minister general. We will mainly consider his biography of Francis that officially replaced Thomas of Celano's vitae in 1266 at the Chapter of Paris, ${ }^{58}$ as well as Bonaventure's scripture-based meditations on the biography of Jesus Christ entitled The Tree of Life, and his sermons dealing specifically with the founder, Francis. These will be drawn from editions published by Ewert H. Cousins and Eric Doyle O.F.M. ${ }^{59}$

Sermons that were preached by Franciscans in the thirteenth century have been useful in building a case for their commitment to orthodox teaching against heterodox groups. While numerous manuscripts of Franciscan sermon collections exist, few have been translated or received critical scholarly attention. ${ }^{60}$ Beyond Thomas of Celano and Bonaventure, I studied several additional early Franciscan preachers. The writings of Servasanto da Faenza, a Franciscan based in mid-thirteenth century Florence, disclose that the preacher was in the midst of a battle between the orthodox and the heterodox. Raymond Dansereau's dissertation examines the sermons of Servasanto that are contained in 47 manuscripts extant from between the thirteenth and fifteenth centuries. ${ }^{61}$

${ }^{58}$ Cook, "Dossal in Siena," 17-18.

\footnotetext{
${ }^{59}$ Bonaventure and Ewert Cousins, Bonaventure: The Soul's Journey into God; The Tree of Life, The Life of St. Francis (New York: Paulist Press, 1978); Bonaventure, Eric Doyle, The Disciple and the Master: St. Bonaventure's Sermons on St. Francis of Assisi (Chicago, IL: Franciscan Herald Press, 1984).

${ }^{60}$ Cooper, "Preaching Amidst Pictures," 31-32.

${ }^{61}$ Raymond Dansereau, Servasanto Da Faenza: Preaching and Penance in the Work of a Thirteenth-Century Franciscan (PhD dissertation, Rutgers Graduate School-New Brunswick, 2015), 33, http://dx.doi.org/doi:10.7282/T3833TQ3.
} 
One of the strongest contemporary voices to explain the Cathar heresy is that of James Capelli, a Franciscan based in Milan in the middle of the thirteenth century. His Brevis summula contra herrores notatos hereticorum (Brief Treatise Against the Distinctive Errors of Heretics), presents his observations as well as second-hand accounts of the beliefs and practices of the Cathars. Though gently condemning what he sees as their misguided practices, Capelli defends the piety and good works of the Cathars against popular lies and misconceptions. A range of dates is argued for the composition of his summa. Walter Wakefield and Austin Evans hold that it is a mid-century document from 1240-1260, while Lutz Kaelber argues for a 1220 dating with a less certain authorship attributed to Pseudo-Capelli. ${ }^{62}$

A wider collection of Franciscan sermons can be found in David D'Avray's The Preaching of the Friars: Sermons Diffused from Paris before 1300. D'Avray's study looks at 'model' sermons that were produced by brothers teaching at the University of Paris. While composed in an academic setting, the collections were mostly prepared to assist in popular preaching throughout Europe - to an audience of increasing religious literacy. D'Avray presents the history of the apostolic movement and the preaching revival that existed preceding and concurrent with the early Franciscans. ${ }^{63}$

Finally, Antony of Padua (1195-1231) taught in the university of Padua and earned the nickname "hammer of the heretics" for his strong sermons against heterodox

${ }^{62}$ For the sake of simplicity as well as personalization of the friar, I will use the name James Capelli for the author of this work. Wakefield and Evans, Heresies, 302-4, 352-58; Lutz Kaelber, Schools of Asceticism: Ideology and Organization in Medieval Religious Communities (University Park, Pennsylvania: Pennsylvania State University Press, 1998) 183.

${ }^{63}$ D. L D’Avray, The Preaching of the Friars: Sermons Diffused from Paris Before 1300 (Oxford, England: Oxford University Press, 1985), 2, 10. 
beliefs. Interestingly, Antony was reputed as a forceful and exuberant preacher, yet he refused to use "fables" in his sermons. ${ }^{64}$ While there was little to connect his texts to the Franciscan artwork, reading his sermons provided insight to the scriptural basis for Catholic doctrine in rejection of heresy. John Moorman's A History of the Franciscan Order: From Its Origins to the Year 1517 served as a useful introduction to Antony. Written in 1998, it is considered by William Cook to be the most thorough accounts of the Order of Friars minor between the death of Francis and the era of Bonaventure's leadership (1226-1257). ${ }^{65}$

Continuing with secondary sources for the religious scholarship, I learned a great deal from authors such as Carolyn Muessig, Beverly Mayne Kienzle, Cynthia Polecritti, and Augustine Thompson who explore the practical, historical, and theological aspects of evangelization from the twelfth century and beyond. In Franciscan Literature of Religious Instruction before the Council of Trent, Bert Roest offers an overview of the most prolific Franciscan writers' pedagogical texts. According to Roest, "catechetical instruction and edification formed the backbone of the Franciscan pastoral endeavor." Although he deliberately omitted discussion of "catechetical iconography" as being beyond his expertise, he recognizes the importance that the Franciscans' artistic contributions played in their efforts to teach both the general public and their fellow religious.

\footnotetext{
${ }^{64}$ John Moorman, A History of the Franciscan Order: From Its Origins to the Year 1517 (Oxford: Oxford University Press, 1998), 277.

${ }^{65}$ Cook, "Fraternal," 268.

${ }^{66}$ Bert Roest, Franciscan Literature of Religious Instruction before the Council of Trent (Leiden, Netherlands: Brill, 2004), xviii.
} 
Rosalind Brooke has long stood as a notable Franciscan scholar. In her small but powerful volume, The Coming of the Friars (1975), she analyzes the orthodox and heretical precursors and the early development of the Franciscan and Dominican orders. The second half of the book presents her translations of documents that support these new mendicants' nascent stages. Brooke's more recent volume The Image of St. Francis combines her analysis of both textual and visual images, providing a comprehensive treatment to the vita dossals.

As this review of the literature has hopefully made evident, the scholarship of many researchers from a variety of fields has contributed to this project. In the next section, I will build on the foundation they have crafted to explore the history, theology, and materiality of the Franciscans, the Cathars, and the wood-panel paintings at the center of their crossroads. 


\section{Chapter 1: Heresy and Reform}

\section{The Religious and Historical Context}

As I made clear in the introduction, I proceed under the assumption that the Cathars existed by the second quarter of the thirteenth century as a diverse yet distinct Christian entity. This chapter establishes a starting point for how early Franciscan art served as a response to the Cathars by considering the history and theology of the major players. It will begin with the Western Church's first recorded encounter with the sect and an exploration of the Cathars' roots in the East and diffusion into Europe. Narrowing our focus to the Italian region, the chapter will consider Francis of Assisi and the Cathars sharing the same thirteenth-century cultural context that was heavily influenced by the Catholic Church during a pivotal point of its doctrinal development following the Fourth Lateran Council.

Although the heterodoxy of Catharism spread across Europe in the twelfth and thirteenth centuries, few first-hand accounts survive to tell the story. What is known of the Cathars' history is, for the most part, relayed through contentious sources: the eyes of the Catholic Church and the depositions of Cathar adherents given during periods of inquisition. ${ }^{67}$ The earliest textual evidence for a dualist heterodoxy in Europe comes from a letter written by Eberwin of Steinfeld, the provost of an abbey near Cologne, to Bernard of Clairvaux in 1143. A copy of this letter, in which Eberwin requests assistance for

\footnotetext{
${ }^{67}$ Lambert, The Cathars, 2.
} 
dealing with two new heretical groups, is included in Bernard's Sermons on the Song of

Songs: ${ }^{68}$

There have been lately discovered among us in the neighbourhood of Cologne certain heretics, of whom some have made amends of their fault (cum satisfaction) and returned to the Church. Two among them, namely, he who was called their bishop, and his companion, have withstood us in an open assembly of clerics and laymen, in which the lord Archbishop himself was present, and some noblemen of high rank, and defended their heresy by the words of Christ and His Apostle. But when they saw that they could make no progress, they requested that a day might be assigned to them on which they might bring forward men of their community who were well skilled in their faith. They professed that, if they saw that their teachers were unable to reply satisfactorily to the objections made to them, they were willing to submit to the Church; but that otherwise they had rather die than give up their opinions. To these propositions reply was made by admonitions, continued during three days consecutively; but they were unwilling to yield or to come to a better mind. They were then seized and carried off by the people, who were transported by an excessive zeal; but quite against our will; and being cast into the fire by them, were consumed; and, which is a fact still more to be wondered at, they entered into and endured that torment of fire, not only with patience, but with joy. Here, holy father, I should wish, if I were present with you, to have your explanation, whence it is that those members of the devil have fortitude so great in their heresy as is scarcely equaled by those most sincerely attached to the faith of Christ.

This is their heresy: They say that the Church exists among them only, since they alone follow closely in the footsteps of Christ, and remain the true followers of the manner of life observed by the Apostles, inasmuch as they possess neither houses, nor fields, nor property of any kinds. They declare that, as Christ did not possess any of these Himself, so He did not permit His disciples to possess them. 'But you,' they say to us, 'add house to house, and field to field, and seek the things of this world. So completely is this the case, that even those among you who are considered the most perfect, such as the monks and regular canons, possess these things, if not as their private property, yet as belonging to their

68 The monk is also known as Eversin or Everwin, depending on the translation. Bernard of Clairvaux, "Letter of Eberwin, Provost of Steinfeld, to Abbott Bernard," Life and Works of Saint Bernard, Abbot of Clairvaux: Volume 4: Cantica Canticorum Eighty-Six Sermons On The Song Of Solomon, ed. Jean Mabillon, trans. Samuel J. Eales (London: J. Hodges, 1889), 388-93, http://archive.org/details/LifeAndWorksOfSaintBernardV4; Wakefield and Evans, Heresies, 26; another translation of Eberwin's letter is found in Robert Moore, The Birth of Popular Heresy (Toronto: University of Toronto Press in association with the Medieval Academy of America, 1995), 74-78, Birth of Heresy. Bernard's $65^{\text {th }}$ sermon provides his response to Eberwin. 
community.' Of themselves they say: 'We are the poor of Christ; we have no settled dwelling-place; we flee from city to city, as sheep in the midst of wolves; we endure persecution, as did the Apostles and the martyrs; yet we lead a holy and austere life in fasting and abstinence, continuing day and night in labours and prayers, and seeking from these only what is necessary to sustain life.'....In respect of food, they forbid every kinds of milk, that which is made of milk, and whatsoever is the product of that function. It is in this particular that their manner of living is opposed to ours. In the reception of their Sacraments they cover the head with a veil, yet they have openly avowed to us that daily at their table whey they eat they, according to the usage of the Apostles, consecrate, by saying the Lord's Prayer, their food and drink into the Body and Blood of Christ, so that by it they may be nourished as the members and body of Christ. They say that we do not hold the truth as to the Sacraments, but only a certain shadow of it, and tradition of men. They confess also plainly that besides the baptism with water, they give and receive a baptism with the Spirit and with fire, and are therewith baptized, adducing that testimony of John the Baptist, who, himself baptizing with water, said of Christ: He shall baptize you with the Holy Ghost and with fire (Matt. iii. II)...And that such a Baptism ought to be bestowed by imposition of hands, they have endeavoured to show by the testimony of St. Luke, who, describing in the Acts of the Apostles the baptism of Saul (Pauli), which he received from Ananias at the direction of Christ, makes no mention of water, but only of the laying on of hands (Acts ix. 17,18); and they pretend that whatever is found in the Acts, or in the Epistles of St. Paul, respecting the laying on of hands has reference to this baptism. Whoseover among them has received this baptism is called by them Elect; he has the power to baptize others, who shall be found worthy of receiving that baptism, and of consecrating at his table the Body and Blood of Christ. They previously receive him by the laying on of hands, from the number of those whom they call Hearers, into the ranks of the Believers; and thus he will gain the right to be present at their prayers, until, after sufficient proof of fitness, he shall be made one of the Elect. Of our Baptism they take no account. Marriage they condemn, but for what reason I have not been able to ascertain-either because they have no reason to give, or because they do not dare to avow it.

Eberwin continues in his letter to describe a separate heretical movement whose beliefs vary from the first, but which still is related to dualism. Their mutual enmity evidently is what brought both movements to the attention of the Church. This second group denies the true presence of the Body of Christ in the Eucharist because the priests presiding over the Mass were not legitimately ordained, due to the Church being 
consumed by the material world. Baptism is the only sacrament they subscribe to, and then only for adults. Marriage is allowed only between male and female virgins - all others commit the sin of fornication. The intercession of the saints, fasting, and other mortifying disciplines are unnecessary because they did not believe in purgatory — once a person died, they were immediately judged for Heaven or Hell.

Eberwin concludes his letter to Bernard, returning to the first group of heretics he had described:

Against all these forms of evil, so many and so varied, I entreat you, holy father, to let your solicitude be on the watch, and to direct the point of your sharp arrow upon these beasts of prey... You should know also, my lord, that those who have returned to the Church have told us that they have a very great multitude of adherents scattered almost everywhere throughout the countries, and that among these they count very many of our clerks and monks. Those who were burned said to us in their defence that this heresy has had a secret existence from the times of the martyrs even to our own day, and that it still remains in Greece and in some other countries. Such as those heretics who call themselves apostles, and have a pope of their own. Others there are who, though they do not acknowledge our Pope, yet allow that they have no other. Those emissaries (apostolici) of Satan have also among them (as they say) women vowed to continence, widows, and virgins; they have also their wives, some among the elect, others among the believers, as if to follow the example of the Apostles who was conceded the power of taking about their wives with them. Farewell in the Lord. $^{69}$

Although Eberwin's letter to Bernard does not perfectly correspond to the beliefs of thirteenth-century Italian Cathars, the doctrine expounded in it is apparently dualist, as evidenced by its contempt for the material world and many of the sacramental and social details corresponding sufficiently to relate it to the Cathar communities. The supposed domestic Mass the letter describes, in which the Elect "consecrate, by saying the Lord's

${ }^{69}$ Bernard of Clairvaux, "Letter of Eberwin, Provost of Steinfeld, to Abbott Bernard," 388-93; See also Moore, The Birth of Popular Heresy, 74-78. 
Prayer, their food and drink into the Body and Blood of Christ, so that by it they may be nourished as the members and body of Christ" is the most problematic tenet in that thirteenth-century Cathars did not claim the presence of the body of Christ in their sacrament. This can be explained by confusion on Eberwin's part, faulty testimony or inaccurate understanding of the belief by the witness, or an actual variation in the heterodoxy.

R. I. Moore acknowledges that at the 2013 conference at University College London, there was general agreement that this letter by Eberwin describes the existence of a dualist movement that had developed in the East and "that by the end of the twelfth century this movement was widely spread and deeply rooted." ${ }^{70}$ Although not named in the letter, Eberwin is believed to be describing the Cathars or a closely related sect. The origins of the Cathars' philosophies can be traced back to an adaptation of Bogomilism, a Christian heterodoxy founded in Bulgaria that rejected the beliefs of the Catholic Church. ${ }^{71}$ Stemming from the East, Lambert describes a migration of Cathar beliefs directly to Italy from the Balkans. He and Emmanuel Le Roy Ladurie describe Catharism as progressing through the Byzantine Empire in the eleventh century and spreading rapidly across the north and central Italian peninsula by the later part of the twelfth century or early thirteenth century. ${ }^{72}$

Walter Wakefield and Austin Evans argue an alternative theory of Cathar development in western Europe, proposing that prior to the twelfth century, an

\footnotetext{
${ }^{70}$ Moore, "Principles at Stake," 260.

${ }^{71}$ Lambert., The Cathars, 23.

${ }^{72}$ Ladurie, Montaillou, viii. Lambert, The Cathars, 1.
} 
indigenous and amorphous form of dualism already existed in the West. ${ }^{73}$ In this model, a disparate community holding such beliefs eventually became more defined by the introduction of Bogomil-influenced rituals, doctrine, and organization that entered into France through the work of traveling merchants, converted crusaders returning to their homeland, and Balkan missionaries who were fleeing persecution. Wakefield and Evans claim that from northern France, preachers brought Catharism into Italy. They established a strong foothold by 1150 or 1160 , bolstered by a rising fervor of lay piety already present there.

Contrary to Pegg who claims substantial growth for dualism only following 1229 , Wakefield and Evans see the period between 1150 and 1210 as the "...great age of growth of medieval heresy," with the Cathars reaching peak activity in the 1230s1240s ${ }^{74}$ Lorenzo Paolini agrees with Wakefield and Evans' earlier timeframe, recognizing Catharism as being "fully a part of lay piety" in Italy by the second half of the twelfth century ${ }^{75}$ Its penetration through society created large-scale fear and unrest both in its self-promotion and in the religious and secular reaction to suppress it. ${ }^{76}$ Of all the medieval heterodox communities, Cathars are considered to have been the most harshly attacked by the Church in its attempt to rout them from European society. ${ }^{77}$

${ }^{73}$ Information in this section is drawn from Wakefield and Evans, Heresies, 19, 27, 31, 40.

${ }^{74}$ Wakefield and Evans, Heresies, 28.

${ }^{75}$ Paolini, "Italian Catharism," 86.

${ }^{76}$ Ladurie, Montaillou, viii. Lambert, The Cathars, 1.

${ }^{77}$ Anne Brenon et al., "Cathars and the Representation of the Divine: Christians of the Invisible," in Women Preachers and Prophets through Two Millennia of Christianity (Berkeley: University of California Press, 1998), 247. 
Although a Christian religion, the Cathars did not consider themselves a vehicle of reform for the Catholic Church. It was not simply that they disagreed with a number of doctrinal items. Rather the Cathars considered themselves to be the "true Christians"seeing themselves as a direct opponent to what they considered to be the Church of Satan. ${ }^{78}$ They claimed apostolic succession, universality, and a creed that had been passed down from the early martyrs to the present age in eastern lands. ${ }^{79}$ Conversion to Cathar beliefs often occurred on a personal level, with one-to-one invitation and interaction. The conversation continued with a gradual introduction to the apocryphal revelations made to earlier Cathars. Convinced of their superiority and direct apostolic lineage they believed only Cathar souls would be saved. ${ }^{80}$

Diversity was manifest amongst Cathar doctrines, and not every Perfectus, the most commonly used term for the Cathar Elect, preached the same belief. ${ }^{81}$ Though quite late in the history of the Cathars, the inquisition testimonies of three leaders provide an extensive historical record of Cathar beliefs. The doctrine taught by Pierre Autier and Guilhem Bélibaste falls within the mainstream of Cathar conviction and can provide examples of the varied beliefs posited in the heterodoxy. ${ }^{82}$ Pierre Autier (c. 1245-1310) preached a creation story in which Satan stood outside the gates of paradise for one

${ }^{78}$ Le Roy Ladurie, Montaillou, viii; Lambert, The Cathars, 21.

${ }^{79}$ Bernard of Clairvaux, "Letter of Eberwin, Provost of Steinfeld, to Abbott Bernard," Saint Bernard, 388-93.

${ }^{80}$ Lambert, The Cathars, 246-47.

${ }^{81}$ Lambert, The Cathars, 250-253.

${ }^{82}$ The testimony of these Cathar leaders was attained between 1309-1321. Lambert, The Cathars, 230; Ladurie, Montaillou, 319-320. 
thousand years until he was able to seduce some of the angels of Heaven. These angels were composed of a "soul, heavenly body and spirit." ${ }^{83}$ With promises of treasures and wives he tempted them to leave paradise until "they fell like rain upon the earth over nine days and nights." Satan trapped the angels in bodies so they would forget their past. But he had to ask for God to animate them. Autier believed that God permitted the angels to depart Heaven but would allow their return one day. In a kind of reincarnation, the angels would need to move between human and animal bodies until they found themselves in the body of a Cathar. Once the Cathar was ritually consoled (cleansed), the angel could return to paradise. There would be no bodily salvation, however, as the physical body would remain bound to the evil earth. The clergy of the Catholic Church, Autier preached, were the leaders of the angels who first abandoned Heaven. Even they could eventually return, but their transmigration from body to body would entail worse suffering. Autier considered the world itself to already be hell, with the earth taking on a state of full damnation when all the repentant angels returned to paradise. ${ }^{84}$

Guilhem Bélibaste explained the dualism of the Cathar doctrine by saying: The heavenly Father has nothing of his own in this visible world but the spirits, which the Devil formerly made fall from Paradise...And the heavenly Father does not make anything in this world, neither the blooming of flowers nor the sprouting of grain, neither conceiving nor giving birth, nor producing an embryo. Overall he does not make anything in this world. ${ }^{85}$

${ }^{83}$ Quotes in this section are taken from Lambert, The Cathars, 250-251. Also see Ladurie, Montaillou, 325.

${ }^{84}$ Lambert, The Cathars, 252, 254; Ladurie, Montaillou, 361.

${ }^{85}$ Brenon et al., "Cathars and the Representation," 253. 
In Cathar belief, God created nothing on Earth. The "visible" and "corruptible" world is entirely of the devil's making. ${ }^{86}$ While all Cathars held this tenet of the materialspiritual divide, variations of belief existed between absolute dualism, which was more common in Languedoc, and the modified dualism found in Italy ${ }^{87}$ Absolute dualism held that there were two equal and eternally opposed principles: a good principle and an evil principle. Modified dualists believed that the good principle, whom they named God, was more powerful and eternal than the bad principle, called Satan, the Devil or Lucifer. ${ }^{88}$ Cathars believed the Catholic Church was in league with the Devil, cooperative with the created evil earth, and opposed to the Divine. ${ }^{89}$ This evil principle was, further, believed to be the god spoken of in the Old Testament: the creator of all visible, mutable, and corruptible matter. In his dissertation on the writings of the thirteen-century Franciscan preacher James Capelli, Walter Wakefield explains:

Because the heretics believe that Lucifer was the god of the Old Testament, they also assert that the Prophets were his spokesmen, except on those occasions when, coerced by the Holy Spirit, they prophesied of Christ. At such times, however, they knew no more of the meaning of their words than would brute animals. ${ }^{90}$

Therefore Cathars accepted the revelation of the prophets but rejected other scripture prior to the Christian gospels. ${ }^{91}$

${ }^{86}$ Brenon et al., "Cathars and the Representation," 252.

${ }^{87}$ Wakefield and Evans, Heresies, 47-48.

${ }^{88}$ Ladurie, Montaillou, viii.

${ }^{89}$ Brenon et al., "Cathars and the Representation,” 249.

${ }^{90}$ Walter Wakefield, "The Treatise Against Heretics of James Capelli; A Study of Medieval Writing and Preaching Against Catharan Heresy." (PhD Dissertation, Columbia University, 1951), 38.

${ }^{91}$ Wakefield and Evans, Heresies, 48. 
The Cathar teachings regarding Jesus differ greatly not only from Catholic theology, but also among the various communities of the heterodox believers. Absolute dualists held that Jesus was an angel who, through the body of Mary (also an angel) entered into the world. They argue that he never acquired human flesh nor interacted physically with earthly matter. Some modified dualists believed that Jesus, Mary, and John the Baptist were angelic beings; while others held that Mary was a human and that Jesus had adopted a physical human form from her. Others protested that this human form was fashioned from a different substance than a normal earthly body.$^{92}$ Two reconciled Cathars, named only as Andreas and Pietro, testified to Pope Gregory IX (r. 1227-1241) that they had formerly believed "the son of God came in the Blessed Virgin Mary, who was made of superior elements, and took flesh from her and not from these elements, and descended from heaven with one hundred forty-seven thousand angels. ${ }^{993}$

Wakefield and Evans offer yet another version of what and who Jesus is, set forth by a specific group of Italian Cathars, called interchangeably the Albanenses or Albigenses. ${ }^{94}$ It is a translation from the mid-thirteenth century compilation of James Capelli, known as the Brevis summula contra herrores notatos hereticorum:

\footnotetext{
${ }^{92}$ Specifics about sectarian beliefs regarding Mary and Jesus can be found in Wakefield and Evans, Heresies, 40, 48.

${ }^{93}$ Lansing, Power and Purity, 85-86.

${ }^{94}$ Substitution of the two names is frequent in copies of the summa. Wakefield and Evans explain this in footnote 5 of section 53, blaming either the fame of the Albigensians of Languedoc, a transcription error of an ill-informed clerk, or beliefs held in common by both groups. The names of heterodox believers in Italy varied based on local tendencies and affiliation with certain leaders. Cathar, Patarine, and Gazar were most commonly used. Albanenses, Concorezzenses, Bajolenses, Caloiani, and Fancigene were other appellatives. See Wakefield and Evans, Heresies, 42, 749; Wakefield, "Treatise Against Heretics," 127, 179-80; Caterina Bruschi, "Converted-Turned-Inquisitors and the Image of the Adversary: Ranier Sacconi Explains Cathars," in Cathars in Question, ed. Antonio Sennis (University of York, 2018), 204.
} 
Also, it is the heresy of the Albigenses which was that Lucifer was the son of the evil god and that he ascended into heaven and found the wife of the celestial king without her husband, that is, God. There he went so far as to lie with her...And they say that thus Christ was born and thus He brought His flesh down from heaven and this is their great secret. They seek also to maintain that He was not true man but an angel incarnate, that He was not the son of the Blessed Mary and so did not take on flesh from her, and that He did not eat or drink in the flesh, did not suffer in the flesh, and in His body did not die. They say that all these and like acts which $\mathrm{He}$ performed He did in appearance only, not in fact. And likewise they say that He did not rise again and was not dead... all these things occurred only in outward appearance...They say that He did not suffer our afflictions, such as hunger, cold, and the like. They allege also that He is not greater than all others, nor equal to the Father; and they say He is not God. ${ }^{95}$

The above texts reveal the nuances in beliefs held by those religious sects which modern scholars consolidate under the name Cathar, yet their similarities outweigh their differences.

For the purpose of this study, it is crucial to note that, in addition to dualism, all Cathars also held docetist beliefs. In their view, because of the inherent corruption of physical matter, they postulated that Jesus could not have possessed a body. The Cathars thought that it was dishonorable to believe, as Catholics did, that Jesus underwent the same undignified functions natural to the human body. ${ }^{96}$ His human form was merely an illusion taken on by his incorporeal spirit in order to educate and strengthen his followers. The Cathars contended, therefore, that Jesus could not have physically suffered during the events of the Passion. According to James Capelli's description of Cathar tenets, "only in appearance did he suffer death, descend into hell, or ascend to heaven in the

${ }^{95}$ Wakefield and Evans, Heresies, 353-54.

${ }^{96}$ Unless noted, descriptions of Cathar beliefs in this section are based on Wakefield, "Treatise Against Heretics," 41; Catherine Léglu, ed., The Cathars and the Albigensian Crusade: A Sourcebook (London: Routledge, 2014), 4-6. 
flesh.” This divergence from orthodox doctrine will especially shape my final chapter, when we will look at the iconography of the Franciscan crucifixes in which the apparent suffering of Christ takes a pivotal role.

Considered the most treacherous of heterodoxies, the Cathars were held by the Catholic Church as their greatest rival in the twelfth and thirteenth centuries. Rather than the Cathars' actual teachings being the main attractor, though, Catharism appealed instead through the "demonstration of piety and rigorous morality" that the most dedicated followers expressed through their lifestyle ${ }^{97}$ The Consolamentum was the only sacrament practiced by the Cathars. Receiving it was the necessary action to break the cycle of reincarnation and release a soul into heaven. It absolved the believer of all previous sin and was a convenient and simple resolution to complicated lifestyles. In the ritual, a book of the Gospels was placed on the adherent's head along with spoken blessings. ${ }^{98}$ These prayers included the recitation of the Lord's Prayer and readings from the Gospels, Epistles, and Psalter, in Latin and vernacular languages. ${ }^{99}$ As a sign of purification and renunciation of material goods, it was usually given on one's death bed or in preparation to take on the role of a Perfectus. ${ }^{100}$ While modern scholars had once commonly thought that after a believer was consoled, he or she participated in the endura, or total fasting, Wakefield and Evans state that such suicide by starvation was a

\footnotetext{
${ }^{97}$ Wakefield and Evans, Heresies 5.

${ }^{98}$ Lambert, The Cathars, 21.

${ }^{99}$ Wakefield and Evans, Heresies, 64.

${ }^{100}$ Lambert, The Cathars, 276.
} 
late development and not commonly practiced. ${ }^{101}$ More typical was a moderated fasting even following the Consolamentum. ${ }^{102}$ The validity and effectiveness of the ritual required the presiding Perfecti to be in a sinless state. And if the recipient committed a serious sin after having received the sacrament, the ritual must be repeated to be cleansed once again. $^{103}$

The Perfecti were the Cathar elite, serving the equivalent of priests. They led an austere lifestyle — owning no property and working or begging for their minimal consumption of food and drink. They adopted long routines of cleansing and recitation of the Lord's Prayer. ${ }^{104}$ Fearful of consuming an animal body that contained a reincarnated soul, they abstained from meat, dairy products, and eggs — fasting on bread and water for three days of the week. ${ }^{105}$ With their belief that upon one's death, the soul was again entrapped in either a human or an animal body by the evil god, the Perfecti abstained from sexual relations. They did not want to create more physical bodies to serve as prisons for souls. ${ }^{106}$ Perfecti were overwhelmingly (though not exclusively) male. Carole Lansing recounts evidence for female Perfecti having preached and taught Cathar doctrine in Florence; residing for several months in a Cathar hospice, and giving the

\footnotetext{
${ }^{101}$ Wakefield and Evans, Heresies, 44.

${ }^{102}$ Lansing, Power and Purity, 73.

${ }^{103}$ Wakefield, "Treatise Against Heretics," 44.

${ }^{104}$ Léglu, Albigensian Crusade, 5; Ladurie, Montaillou, 324.

${ }^{105}$ Léglu, Albigensian Crusade, 6.

${ }^{106}$ Léglu, Albigensian Crusade, 5; Ladurie, Montaillou, 324.
} 
consolation (especially to other women) before moving on to another town. ${ }^{107}$ Perfecti had the duties of presiding at meals and blessing the bread, catechizing believers and converts, and offering medical and spiritual counseling. Along with endless hours of wandering, preaching, and covert civil agitation, the Perfecti who remained long in the lifestyle became tempered into authoritative and powerfully charismatic leaders. Serving as missionaries, apologists, and sometimes martyrs, the most devoted Cathar leaders formed an austere heart that strengthened the entire community. ${ }^{108}$

Regarding their hierarchical structure, bishops chosen from the male Perfecti guided the decisions of the local communities and corresponded with the leadership of other regions. Two other Perfecti, called the elder and younger sons, prepared to assume the authority of the bishop upon the head's death or incapacity to serve. Beneath these elite, deacons also assisted the bishops and Perfecti. ${ }^{109}$ As the most numerous of the hierarchically-ranked believers, deacons were considered capable of public instruction and debate, and they provided a monthly communal confession. ${ }^{110}$ They hosted Cathar leaders and travelers of their sect in hospices, providing a network of hospitality and safety from town to town. Converts to the heterodoxy were also housed temporarily by the deacons in preparation for their ritual acceptance.

While the Perfecti took a leadership role, it was not reserved to them as a hierarchical mandate. Every Cathar had the authority (but were not required) to teach,

${ }^{107}$ Lansing, Power and Purity, 118-20.

${ }^{108}$ Lambert, The Cathars, 22, 247.

${ }^{109}$ Léglu, Albigensian Crusade, 6.

${ }^{110}$ Unless stated, information drawn from Wakefield and Evans, Heresies, 45. 
preach, and perform the Consolamentum ritual, according to Wakefield and Evans. While the life of the Cathar leaders who underwent the Consolamentum was demanding, the overwhelming majority of Cathar believers, called credentes, were not required to sacrifice throughout their entire life. ${ }^{111}$ Though holding no official authority or obligations, credentes often provided the leaders with alms, food, shelter, directions, and a receptive audience. Widows regularly took a supporting role to house and provide meals for both male and female elite. ${ }^{112}$

\section{Catharism in Italy}

Compared to Languedoc, the political and religious diversity of the Italian region provided a relative haven for heterodoxy. Missionaries from the Balkans and Constantinople nurtured the Italian Cathars, and an influx of Cathar refugees from France following the Albigensian Crusade (1209-1229) increased their numbers. In the northern regions of Italy by the middle of the twelfth century, Cathars had established communities primarily in the Ghibelline-led cities. These sects tended to develop in the communes that supported the Holy Roman Emperor Frederick I (r. 1155-1190) in opposition to papal authority. These areas, according to Raymond Dansereau, entertained a "freedom that permitted greater religious dissidence." ${ }^{113}$ In general, the Guelph aligned

\footnotetext{
${ }^{111}$ Ladurie, Montaillou, viii.
}

${ }^{112}$ Lambert, The Cathars, 266-67, 276, 279.

113 Abbondio Zuppante, “(In Press) L’Eresia Nella Tuscia Del Duecento e Il Dossale Di San Francesco Di Orte,” ed. C. Canonici, F. De Macedo, Faleritanum. Rivista Di Teologia e Scienze Religiose Aracne; Anno III (2018): Par. 17; Dansereau, Servasanto Da Faenza, 231-32. The emperor did not take the side of the heretics, however, sharing in Pope Lucius III's condemnation of the Cathars at Verona in 1184. See Wakefield and Evans, Heresies, 33. 
with the Roman church, while the Cathars lodged with the Ghibelline. ${ }^{114}$ The divisive atmosphere provided ample room for heterodoxy to grow in Lombardy, Tuscany, Umbria, and the Patrimony of Saint Peter. In central Italy, the active trade routes between Florence and the Balkans seemingly facilitated religious dialogue as well. ${ }^{115}$ Extending from Florence, the Cathars migrated toward Rome, establishing strong communities centered around the Spoleto Valley and Orvieto (See Map 2). ${ }^{116}$

Carol Lansing details the struggle between the orthodox and heterodox in Orvieto - where substantial records provide a rare window to the Italian historical situation. She says that, "Orvieto, like other towns in the Patrimony of Saint Peter, was directly at odds with the papal curia over territory and jurisdiction. The curia was quick to use the interdict to pressure a town by depriving its folk of the sacraments. Surely the long jurisdictional struggles with the popes bred skepticism of claims about papal authority." 117 The ethics of ecclesial decisions were routinely called into question, and Church reform was demanded by the cities whose will it was to determine their own progress. $^{118}$

Prior to the early thirteenth century, there are records of Cathars having participated in community life: working alongside Catholics in city councils, serving as

${ }^{114}$ Zuppante also cites M. D'Alatri, The Franciscan Inquisition, op. Cit., 79. Zuppante, “L'Eresia Nella Tuscia," Par. 26.

${ }^{115}$ Stephens, "Heresy in Florence," 49-50.

116 Zuppante, “L’Eresia Nella Tuscia,” Par. 48.

${ }^{117}$ Lansing, Power and Purity, 159.

${ }^{118}$ Wakefield and Evans, Heresies, 29. 
witnesses in civil courts, and receiving appointments to offices such as rectors, consuls, and town chamberlains. Lambert believes it is unlikely that Cathar beliefs were held in secret in many communities, and rather, there must have been widespread tolerance or shared belief. ${ }^{119}$ In Florence by the 1240 s, members of the elite and merchant classes numbered among the heretics. ${ }^{120}$ Families of wealth and social status were well represented on the official rolls of heretics, but records show the lower classes also joined the ranks, including people employed as cobblers, tanners, and household servants. ${ }^{121}$ Abbondio Zuppante credits craftsmen and artisans with propagating the faith and spreading it to Tuscan, Umbrian, and Lazian cities such as Florence, Orvieto, Viterbo, and Spoleto. ${ }^{122}$

Catharism was not the only heresy to come to prominence in the twelfth and thirteenth centuries; however, the impacts of Catharism were felt more substantially by the Church than the effects of other heterodoxies at that time. ${ }^{123}$ Sharing in the era of Scholastic training by their Catholic contemporaries, Italian Cathars took on roles of intellectual and spiritual authority. ${ }^{124}$ Rather than presenting their own doctrines, Cathars preyed on the doubts of Catholics about the efficacy and morality of their own leaders.

${ }^{119}$ Lambert, The Cathars, 275.

${ }^{120}$ While Lansing believes social and political integration of Cathars was consistent between Orvieto, Florence, and Bologna, she recognizes the difficulty of making comparisons due to the evidence originating at different points in time and varying substantially in its character. Lansing, Power and Purity, 9-10.

${ }^{121}$ Lambert, The Cathars, 275.

122 Zuppante, “L’Eresia Nella Tuscia,” paras. 17, 23.

${ }^{123}$ Lambert, The Cathars, 1.

${ }^{124}$ Stephens, "Heresy in Florence," 49-50. 
According to Lambert, "The object of the leadership was to break down the structure of custom and ritual which retained Catholicism's place in daily life, and to replace it with a set of Cathar observances." ${ }^{" 125}$ While the Perfecti and other church leaders were educated in their doctrine, inquisitional records show that most people who were accused of heresy had little understanding of religious precepts. Mainly, the community recognized in the Perfecti's ascetic lifestyle a holiness that they admired. Their followers "accepted their teaching that the Roman Church could not save and that the keys of salvation were now in their [the Perfecti's] hands." ${ }^{126}$

\section{Response of the Church}

Despite widespread acceptance in select locales, in other regions many Cathars hid their religion - pretending instead to be united to the Church for fear of the communal ostracization of excommunication, or even physical abuse. ${ }^{127}$ However, as their population increased, says Wakefield, the Cathars began to be "blamed for a chief share in the perennial political and ecclesiastical troubles of the Italian cities." ${ }^{128}$ In Heresies of the High Middle Ages, Wakefield and Evans offer an account from the "Life of Saint Galdini," written in the Acta Sanctorum, around 1176: "The heresy of the Cathars began to spread in the city and was the cause of growing dissension and schism. It grew so much under pressure of sin that many persons publicly preached it and other errors with

${ }^{125}$ Lambert, The Cathars, 249.

${ }^{126}$ Lambert, The Cathars, 277.

${ }^{127}$ Barbara Newman, "Introduction," in Hildegard of Bingen, Columba Hart, and Jane Bishop. Scivias (New York: Paulist Press, 1990), 35.

${ }^{128}$ Wakefield and Evans, Heresies, 31. 
reckless audacity and the souls of many simple folk were caught in the snares of the devil's deceit."129 The Catholic Church understood itself as a unified body, but heresies were diverse in their beliefs and practices. This multiplicity gave credence to the concept that heterodoxies originated with the devil and were spread through sorcery, orgies, ashes of burnt children, and scatological feasts. ${ }^{130}$ Toleration of varying religious beliefs waned, and people who practiced different religions began to be seen as "guilty of incorrectness that should be remedied...people willfully dismissing the central tenets and truths of Christian belief were to be converted or considered to be at fault." ${ }^{131}$ Local Catholic bishops often failed at handling these multifaceted social and religious impasses. They were untrained in battling the complex apologetics used by the eloquent leaders of heterodox movements and sometimes even ignorant of their own orthodox doctrine. In some instances, bishops were too overwhelmed by secular affairs to give a fair hearing, serving as they did as both religious heads and lords of the manor. ${ }^{132}$

A lull in active, or at least prevalent, heresies occurred during the period between the decline of the Carolingian Empire and the fin de millennium. Subsequently the twelfth- and thirteen-century reaction to heterodoxy was modeled on the writings of the fourth-century theologian Augustine of Hippo (354-430) who had dealt with the heresies of his own day, specifically the Manicheans and Donatists. His warnings regarding the "secret vices" of the heretical practitioners and the subsequent heavy-handed suppression

\footnotetext{
${ }^{129}$ Vita sancti Galdini, April 18, II, 591 in Heresies, 151.

${ }^{130}$ Lambert, The Cathars, 8-10.

${ }^{131}$ Léglu, The Cathars and the Albigensian Crusade, 4.

${ }^{132}$ Information in this part drawn from Lambert, The Cathars, 4-6, 16-18.
} 
influenced the reactions of the later medieval period. Crowds and soldiers would, on occasion, take it upon themselves to persecute accused heretics. Likewise, despite the Cathar Perfecti's dedication to non-violence, the cultivated belligerence sometimes erupted viciously, as when a papal-appointed mayor was installed in Orvieto. His murder by Cathar supporters and the subsequent reprisal by Catholics spread violence between towns. Zuppante points to this event as the origin of the papal bull Vergentis in senium (1199), the first pontifical juridical text against heresy, directed against the Cathars who had fled Orvieto for Viterbo. ${ }^{133}$ In this document, Pope Innocent III (r. 1198-1216) declared that heresy should be considered treason. Lansing explains: "This definition relied on an understanding of the sovereign status and unique judicial authority of the pope as Christ's representative: the pope alone is able to judge that heresy, as an attack on the faith that is the foundation of Christian society, constitutes an attack on papal sovereignty." ${ }^{" 134}$ Innocent III followed this with the publication of the Ad eliminandam, a constitution against heretics in $1207 .{ }^{135}$

Inquisitional proceedings began in the twelfth century under Pope Innocent III as an attempt to moderate secular mass lynching. The process of interrogation was anything but merciful, however. Torture, trial by ordeal, and capital punishments were carried out by the secular power at the direction of not only the clergy, but also secular nobility eager to profess their orthodoxy and lay mobs hoping to rid their villages of heretical contagion. Although the death penalty was discouraged by Augustine's texts, the

\footnotetext{
${ }^{133}$ Zuppante, “L’Eresia Nella Tuscia,” Par. 23.

${ }^{134}$ Lansing, Power and Purity, 33.

135 Zuppante, “L’Eresia Nella Tuscia,” Par. 24.
} 
contemporary histories discussed it as an unfortunate need. ${ }^{136}$ Officially, capital punishment in retribution for heresy was not dictated until 1224 when Emperor Frederick II (r. 1220-1250) included it in his constitutions. ${ }^{137}$ The number of people executed under the direction of the Church in the official inquisition records numbered remarkably fewer than popular history or fiction would suggest, however. ${ }^{138}$ More typical punishments included imprisonment, marking with yellow crosses worn on clothing, confiscation of property and disinheritance over multiple generations, excommunication, and forced pilgrimages. ${ }^{139}$ Pope Innocent III developed a policy which demanded municipal officials take charge of actions against heresy, rather than the local bishops, handling them through political pressure and the civic law. ${ }^{140}$ Still, Catharism spread. The secular clergy were ill-equipped to battle the Cathar elite-limited as they were by their sparse numbers over a vast geography, comparatively wealthy and morally lax when set against a Cathar Perfectus, and often prepared only with weak theological training. ${ }^{141}$ Dated from the 1220s, the letters of Raniero, bishop of Viterbo (r. 1199-1222), reveal his desperation as he claims that in their preaching, his local priests were unable to defeat the doctrinal

${ }^{136}$ Lambert, The Cathars, 17-18.

${ }^{137}$ Lansing, Power and Purity, 31.

${ }^{138}$ For example, five people were executed at the hotbed of heresy, Montaillou. The records of Geoffrey d'Ablis (d. 1316) at Carassonne, Bernard Gui (1260-1331) at Toulouse, and Jacques Fournier (1285-1342) at Pamiers include roughly one thousand to fifteen-hundred people interrogated. Torture is rarer than supposed with imprisonment and testimony of informants working effectively. Lambert, The Cathars, 258-259.

${ }^{139}$ Ladurie, Montaillou, xvii; Lansing, Power and Purity, 33.

${ }^{140}$ Lambert, The Cathars, 111.

${ }^{141}$ Wakefield, "Treatise Against Heretics," 223. 
maneuverings of their heretical adversaries. ${ }^{142}$ A new model of an ascetical, orthodox preacher was necessary to face the Cathar Perfecti on equal footing.

\section{Francis of Assisi, Founding Brother}

During the twelfth and thirteenth centuries, an increasing number of itinerant preachers, both orthodox and heterodox, strove to adhere to an apostolic life of penance and poverty, calling also for reform among the clergy and greater participation for lay people. ${ }^{143}$ Inarguably, the most successful of these mendicant preachers was Francis of Assisi.

In their early- to mid-thirteenth century biographies, both Thomas of Celano and Bonaventure describe Francis as the son of a prominent cloth merchant in Assisi, one of many small hilltop villages in Umbria. Francis lived a life typical of his luxurious social class, although they make clear that Francis was never enslaved to pleasures or riches but was merely a product of his environment. ${ }^{144}$ As a young adult, Francis underwent a series of conversion experiences during which he recognized the wasteful foolishness of his comfortable lifestyle: he suffered a serious illness, received a visionary dream, and was moved to clothe an impoverished knight and embrace a poor leper. He fully incorporated the counter-cultural dimensions of the Christian faith when he gave to the poor all his

${ }^{142}$ Zuppante, “L’Eresia Nella Tuscia,” Par. 24.

${ }^{143}$ Lambert, The Cathars, 15. Beyond the Cathars, the Poor of Lyons and the Poor Lombards were two of the more notable ascetic reform groups. See Wakefield and Evans, Heresies, 31.

144 Thomas et al., The Francis Trilogy of Thomas of Celano: The Life of Saint Frances, The Remembrance of the Desire of a Soul, The Treatise on the Miracles of Saint Francis (Hyde Park, N.Y.: New City Press, 2004), 22-23. 
family's clothing and money to which he had access. Finally, he became one of the poor he had originally sought to help. ${ }^{145}$

While there is little written about Francis' interaction with Cathar believers, the influence of the Cathars in Assisi cannot be denied. In 1203 the podestà, or chief magistrate of the town, was a Cathar adherent. Francis' family, as merchants, likely interacted with this magistrate. It is known that a Cathar bishop also held sway in the Spoleto Valley, where Francis roamed. ${ }^{146}$ Francis would have been familiar with them and aware of their philosophies, especially their rejection of material goods.

Similar to the Cathars, but by all accounts independently of them, Francis interpreted the Gospels' call for a simple life at face value. The Rule that Francis set down for his followers was inspired by three Gospel passages:

- Matthew 19:21: Jesus saith to him: If thou wilt be perfect, go sell what thou hast, and give to the poor, and thou shalt have treasure in heaven: and come follow me.

- Matthew 16:24: Then Jesus said to his disciples: If any man will come after me, let him deny himself, and take up his cross, and follow me.

- Luke 9:3: And he said to them: Take nothing for your journey; neither staff, nor scrip, nor bread, nor money; neither have two coats. ${ }^{147}$

${ }^{145}$ Bonaventure and Cousins, Bonaventure: Soul's Journey, 185-90.

${ }^{146}$ Lambert, The Cathars, 171.

${ }^{147}$ Bible passages throughout are taken from the Douay-Rheims translation. Francis et al., Francis and Clare: The Complete Works, The Classics of Western Spirituality (New York: Paulist Press, 1982), 109; Armstrong and Francis, St. Francis of Assisi, 64. 
Francis sought the permission of Pope Innocent III to establish his religious order in 1209. ${ }^{148}$ While hesitant to condone the friars' regimen of punishing material deficiency, the pope gave permission for the growing community of brothers to continue their lifestyle of begging and preaching. The brothers took vows of poverty, chastity, and obedience.

The Cathars are not directly discussed in Francis' few extant writings, but an antiCathar sentiment is clearly felt through them. ${ }^{149}$ Evidence shows that Francis was concerned about heresy infecting his fledgling community. By his Rule, he set a guard to protect the order against newcomers who might hold beliefs that were not in keeping with the Church, saying all postulants must have their beliefs verified. Those whose views were not in keeping with orthodox doctrine were to be held for questioning by the Cardinal Protector. ${ }^{150}$ Francis wrote in the Earlier Rule: "All the brothers must be Catholics, [and] live and speak in a Catholic manner. But if any of them has strayed from the Catholic faith and life, in word or in deed, and has not amended his ways, he should be completely expelled from our fraternity."151

\section{The Fourth Lateran Council Addresses Heresy}

${ }^{148}$ Armstrong and Francis, St. Francis of Assisi, 64.

${ }^{149}$ Lambert, The Cathars, 109, 171.

${ }^{150}$ Ugolino dei Conti di Seni, who later became Pope Gregory IX, had been named by Francis as the cardinal protector of the Order of Friars Minor. Lambert, The Cathars, 171.

151 This teaching reflected Francis' commitment to uphold the decrees of the Fourth Lateran Council. See Appendix 1 Fourth Lateran Council Canon 3 On Heresy. Francis et al., Francis and Clare, 124. 
Six years after Francis' Rule was confirmed in Rome, Pope Innocent III called the Fourth Lateran Council to order in 1215. One of its main purposes was to institute Church reforms in response to the spread of the Cathar heresy. ${ }^{152}$ Even on the first day of the plenary session, the bishops discussed how to deal with the regions where dualists had the strongest foothold, in Languedoc; but the Cathar situation to the north was mirrored in Italy, and the council's promulgations applied equally across Europe. The Church approached the issue with a twofold tactic of accepting the return of contrite heretics and utilizing civil law to deal with those who clung to their heterodox doctrines. ${ }^{153}$ As a spiritual incentive for Catholics, an indulgence equivalent to one going on crusade was offered to those who fought against heresy even while remaining in Europe. ${ }^{154}$

The "dogmatic definitions" published by the council were aimed at the dualist, anti-material beliefs of the Cathars (See Appendix 1 for the text of the Fourth Lateran Council: Canon 3 on Heresy). Specifically discussed were the definitions of Real Presence in the Eucharist, the need for Catholic baptism, and the validity of sacramental marriage. Although there is no official record of Francis' presence at the council, it has long been believed that he was there and was greatly affected by Pope Innocent's reformminded goals. Francis focused much of his writing to promote the teachings of the Catholic church that were emphasized during the council; for example, the dual human and divine natures of Jesus, the importance of the Eucharist, the honored role of Catholic

\footnotetext{
152 Armstrong and Francis, St. Francis of Assisi, 43.

${ }^{153}$ Lambert, The Cathars, 111; Wakefield and Evans, Heresies, 33-34.

${ }^{154}$ Unless noted, information in this section is drawn from Lambert, The Cathars, 108, 171.
} 
clergy, and encouragement to frequent churches - all of which countered the Cathars' anti-Catholic impulse.

The documents of the Fourth Lateran Council make clear the major problem that even loyal Catholics were largely ignorant of the tenets of their faith, and the lines between orthodoxy and heterodoxy were not well understood. Lansing presents the example of people participating in both the Cathar Consolamentum and Catholic rituals of baptism and confession with no concern for their contradiction. One main result of the council was the formation of procedures to educate the laity and guide sacramental practice. ${ }^{155}$ A dire obstacle to this goal was the shortage of well-educated preachers, spread too thinly across the many dioceses of Europe. In response, the council decreed that "bishops are ordered to choose suitable men to perform the function of preaching, and to supply these helpers with necessities if need be." ${ }^{\prime 156}$ The strongest weapon in Pope Innocent's arsenal against heretics was his utilization of zealous new religious movements that were similar to the Cathar but faithful to the Church. David D'Avray describes Pope Innocent III's “willingness to take risks in the hope of directing religious fervor into orthodox channels." ${ }^{" 157}$ Prior to the council, the pope had given permission for a group of poor, itinerant clerics and educated laymen known as the Humiliati to preach, and even two formerly heterodox sects, the Poor Catholics and the Reconciled Poor, who had converted back to the Roman Church, were for a time authorized to preach against

${ }^{155}$ Lansing, Power and Purity, 16.

${ }^{156}$ D'Avray, Preaching of the Friars, 15.

${ }^{157}$ D’Avray, 26. 
heretics. ${ }^{158}$ Francis' order, the Friars Minor, were commissioned with a similar task to preach on penance. When Pope Innocent recognized Francis' appeal to allow his community to assemble and grant them the authority to preach, he at first only permitted them the lay preaching role of admonition, that is moral exhortation, rather than praedicatio, dogmatic exhortation, in which only ordained clergy participate. ${ }^{159}$ Wakefield acknowledges the importance of these newly appointed preachers, saying,56 "In the coordination of the resources of the Church on the problem of heresy undertaken by Innocent III, no step was more significant than his encouragement of preaching." ${ }^{160}$ By 1217, the Order of Friars Minor had grown to eleven provinces throughout Italy, France, Germany, Spain, and the Levant. ${ }^{161}$ In urban areas, revival movements and lay confraternities rose in cooperation with the friars' evangelization. These sodalities gave the laity a voice and active participation. Under the direction of the friars and secular clergy they bolstered the efforts toward orthodoxy. With religious and civil cooperation, gradually, laws were enacted against heretics. ${ }^{162}$ In 1229 , a mere three years following Francis' death, we have the first example of the Franciscan order being called into action to combat the Cathar heresy through the arm of an inquisition, although none of the Friars Minor were officially named as an inquisitor at this time. The podestà of

${ }^{158}$ Wakefield, "The Treatise against Heretics of James Capelli; a Study of Medieval Writing and Preaching against Catharan Heresy.," 208-11.

${ }^{159}$ Lambert, The Cathars, 109.

${ }^{160}$ Wakefield, "Treatise Against Heretics," 201.

${ }^{161}$ Unless noted, information is drawn from Derbes, Picturing the Passion, 23-24.

${ }^{162}$ Lambert, The Cathars, 129. 
Milan, supported by Pope Gregory IX, gathered an assembly of "twelve men of proven faith, together with two Dominicans and two Franciscans approved by their respective superiors, who were responsible for searching out and capturing heretics, and remanding them to whomever the archbishop deemed appropriate." ${ }^{163}$ In 1254, Innocent IV (r. 12431254) officially divided the authority for inquisitional powers between the two mendicant orders. The Franciscans were given control over the Patrimony of St. Peter, Umbria, Tuscany, parts of Romagna, the Marches of Ancona and Treviso, Venice, Aquileia, Marittima, and Campagna. The Dominicans controlled Lombardy, the March of Genoa, and the regions of Romagna that encompass Bologna, Ferrara, and Parma (See Map 3). ${ }^{164}$ Through this official position, the Friars Minor were tasked with confronting heresy.

In the next chapter, we will consider how the brothers took the subtle approach of incorporating artwork that promoted Catholic orthodoxy to counter the Cathars' antimaterial stance. We will examine the Cathars' spirituality and practice, looking specifically at material they used or shunned within their religious understanding. Finally, the Franciscans' relationship to art will be introduced along with a brief overview of the dipintura medium that is at the crux of this research: its history and crafting, along with its spiritual implications.

${ }^{163}$ Geoffrey Ward Clement, “A Franciscan Inquisitor's Manual and Its Compositional Context: 'Codex Casanatensis' 1730,” ETD Collection for Fordham University, January 1, 2013, 33.

${ }^{164}$ While both mendicant orders were commissioned with the task of preaching against heresy, it was the primary mission of the Order of Preachers, or Dominicans. Clement, 44-45. 


\section{Chapter 2 Art and Materiality}

\section{Cathars and Materiality}

Cathars believed that all material created things were evil and should be avoided. ${ }^{165}$ Nevertheless, evidence of their using various materia in the same manner as their contemporaries remains from the village of Montaillou. Depositions from its citizens reference earthenware cooking and serving implements such as pots, skillets, cauldrons, decorated basins, metal utensils, and water jars. Traveling salesmen carried needles and spices in trade for the Montaillou sheep's wool and squirrel pelts. While poverty and the mountainous terrain limited the transportation of material goods to a large extent, descriptions of carrying goods held in baskets or tied across one's back make their way into the records. ${ }^{166}$

Within their faith, the Cathars rejected all Catholic sacraments. Those of baptism, Eucharist, confirmation, ordination, and extreme unction incorporate the human body as well as earthly elements such as water, oils, bread, and wine. Penance and marriage require the participation of clergy, whom the Cathar considered unworthy, treacherous, and over-reaching in their authority. ${ }^{167}$ For the orthodox, these rituals were intended to connect the ineffable God with the physical human experience. ${ }^{168}$ But the Cathars were openly hostile to these practices. They opposed the sacrament of baptism saying it was

${ }^{165}$ Léglu, Albigensian Crusade, 6.

${ }^{166}$ Ladurie, Montaillou, 7, 37.

${ }^{167}$ Lambert, The Cathars, 248-52; Lansing, Power and Purity, 99-100; Léglu, Cathars and Albigensian Crusade, 5.

${ }^{168}$ Léglu, Albigensian Crusade, 5. 
descended from John the Baptist rather than Jesus. Preachers told stories of children dying from illnesses brought on by the water of baptism. They planted doubts about the priest maintaining the seal of confidentiality in the sacrament of penance. Pertaining to marriage, credentes were permitted to marry and bear children; and records from Montaillou show they also participated in extramarital affairs. The Perfecti, while avowed to chastity, were also quite susceptible to temptation. ${ }^{169}$ Sexual intercourse was, nevertheless, considered a sin. The Catholic sacrament of marriage, therefore, was judged an even greater depravity because within marriage people had sex more frequently and with impunity. ${ }^{170}$

The collecting of relics, similar to the medieval practice related to Christian saints, betrays an exception to the rejection of matter. Some Cathar households believed the fortune of a family was affiliated with the male head of the household. To maintain this charm, even after the patriarch's death, bodily relics were sometimes collected, usually finger- and toe-nails and hair. Since corpses continue to regenerate these cells for a time after death, they were considered retainers of powerful spiritual energy. ${ }^{171}$ In general though, Cathars ridiculed the veneration of the relics of orthodox saints. ${ }^{172}$

There is scant evidence in the research regarding the Cathars' opinion of art in general or material used specifically for religious purposes; but with their rejection of

169 See Ladurie, Montaillou, Chapters 8-12.

${ }^{170}$ Wakefield and Evans, Heresies, 379-89; Lambert, The Cathars, 248-52. Some Cathars believed that women signified the wickedness of intercourse and that for a woman to find salvation, the female soul would need to change to a male soul after death.

${ }^{171}$ Ladurie, Montaillou, 31.

172 Brenon et al., "Cathars and the Representation,” 249. 
materiality as evil, it would follow that artworks were not held in higher esteem than other matter. Their ascetic movement was based in the beliefs of Bogomilism, which had developed a theological structure that rejected the sacraments, icons, and relics - any mediated symbol of divinity. ${ }^{173}$ In a deposition given to the inquisitor Jacques Fournier, a witness reports that the heretical preacher Guilhem Bélibaste mocked a statue of Mary, saying, "the material church is worthless, and these images of Christ and saints which are seen in it are idols." 174

In her article "Cathars and the Representation of the Divine: Christians of the Invisible," Anne Brenon argues that there was no "material framework for their faith." They had no figural image of holiness and virtually no representation of any persons, animals, plants, or any earthly matter. ${ }^{175}$ This resulted in theirs being the most aniconic of Christian sects. Cathars did not build churches with material accoutrements. Rather, the gathering of believers itself constituted the church. They met in homes owned by individual deacons or corporately owned Cathar houses. During times of persecution, temporary accommodations were sometimes used—barns, cellars, haylofts, or hidden rooms, for example. ${ }^{176} \mathrm{~A}$ deposition from Montaillou describes a chapel tucked inside a Cathar-owned house that was reached through a hole in the adjoining home. ${ }^{177}$ The

${ }^{173}$ Hans Belting, Likeness and Presence: A History of the Image Before the Era of Art (Chicago: University of Chicago Press, 1994), 268.

${ }^{174}$ Arnaut Sicres's testimony before J. Fournier, 1321. Registre d'Inquisition de Jacques Fournier, in: Duvernoy, 1965, II, 53, quoted in Brenon et al., "Cathars and the Representation," 247.

${ }^{175}$ Brenon et al., "Cathars and the Representation," 247.

${ }^{176}$ Brenon et al., "Cathars and the Representation," 250.

${ }^{177}$ Ladurie, Montaillou, 41. 
communal prayer of the Cathar worshippers lacked material supports: there was no altar, no utensils or containers for the sacrifice of the Mass, no processional or standing crucifix, no instrumental or vocal music. ${ }^{178}$ The liturgy involved a simple recitation of prayers, including the Lord's Prayer, and the blessing, dividing, and sharing of bread. ${ }^{179}$ The Book of the Gospels, a candle with which to light the page, a basin of water in which to wash hands, and a table on which to set them all were the only accessories used. ${ }^{180}$ Icons and sculptures particularly earned the ire of the Cathar believers. Thought to constitute the same idolatrous practices that the early Christians had fought against when they refused to sacrifice to pagan gods, Cathars vociferously ridiculed images of Jesus, Mary, and the saints, condemning what they felt were superstitious and idolatrous practices of the Catholic Church. ${ }^{181}$ The Cathar Occitan ritual of Dublin, an Albigensian manuscript which may have been brought to Ireland from Languedoc by the crusader Hugh de Lacy, explains their perspective on churches:

(The Church of God) is not built with stones, or wood, or anything made by human hands. For it is written in the Acts of the Apostles (Act 7, 48): 'The Highest does not dwell in anything made by human hands.' On the contrary, this holy Church is the congregation of the faithful and the holy, in which Jesus Christ stands and will stand until the end of time... ${ }^{182}$

${ }^{178}$ Brenon et al., "Cathars and the Representation," 250.

${ }^{179}$ Wakefield and Evans, Heresies, 379-80.

${ }^{180}$ Brenon et al., "Cathars and the Representation," 250. For additional descriptions of the Cathar communion ritual, see Wakefield, "The Treatise against Heretics of James Capelli; a Study of Medieval Writing and Preaching against Catharan Heresy." 48; and Wakefield and Evans, Heresies of the High Middle Ages, 382-83.

${ }^{181}$ Brenon et al., "Cathars and the Representation," 249.

${ }^{182}$ Cathar Occitan ritual of Dublin is also known as the Trinity College Dublin, Manuscript 269. Brenon et al., 250; Anne Brenon, "The Occitan Cathar Manuscript of Dublin (Ms 269 Tcd): A Unique Window into Dissident Religiosity," in From Carrickfergus to Carcassonne: the epic deeds of Hugh de 
The only religious material known to have been produced by Cathars was the copying of books, specifically books from the New Testament. Of the few Cathar manuscripts and fragments that remain, only a copy of the New Testament known as the Bible of Lyons, Manuscript PA 36 from the Municipal Library of Lyon, is decorated, containing thirty partial to full page incipits. ${ }^{183}$ While these initial pages are elaborate and large, they contain for the most part only geometric and abstracted patterns. Any figural or vegetal decoration are absent with two exceptions. One lily was inserted in a marginal section of a page, and depictions of a fish are scattered throughout the manuscript. Anne Brenon, who performed an initial study of the manuscript, theorizes that the lily is a symbol for both purity and asexual reproduction, based on the admonition of Jesus to "Look at the lilies of the field..." who do not worry about material goods yet they are protected by God. Brenon considers the symbolic use of the fish as an early Christian abbreviation but also holds that the meaning of the image of the fish is similar to that of the lily, in that it was believed fish also generated asexually. Therefore, Cathars considered them an allowable food source—-safe from holding a soul—and even encouraged by Jesus in his miracle of the multiplication of the loaves and fish. Brenon says the style of geometric, abstract decoration most used throughout Ms PA 36 is unique among small Latin bibles that use the same style of filigree initials. Due to the extent of the loss of Cathar-produced

Lacy during the Albigensian crusade, ed. Paul R Duffy, Tadhg O'Keeffe, and Jean-Michel Picard, 2017, $107-28$.

183 This section is based on Brenon et al., "Cathars and the Representation," 254, 256, 259. Scriptural passages that are referenced are Matthew 6: 28-30; Luke 12:27-28; Matthew 14:13-21; Mark 6:31-44; Luke 9:12-17; John 6:1-14. Muslim calligraphic decoration may have influenced the work stylistically, although the aniconic motivations would have stemmed from a different theological foundation. I hope to study this manuscript in a future research project. 
manuscripts, it is impossible to know whether this kind of decoration was common among heterodox scripture or if this book was an outlier, preserved mainly for its beauty.

\section{The Artistic Context of the Early Franciscans}

The material lifestyle of the early Franciscans was similar to that of the Cathar Perfecti, eschewing personal possessions. Rather than enclosing themselves in a traditional monastery, these early friars lived in wooden huts and begged alms to meet their physical needs. ${ }^{184}$ Francis calls on the brothers to make use of homes or churches as guests and pilgrims. Trinita Kennedy elaborates: "art had no place in the original intentions of their founders...[Francis] reminds his own followers that they 'must be careful not to accept any churches, poor dwellings, or anything else constructed for them unless these buildings reflect the holy poverty promised by us in the Rule." ${ }^{\prime 185}$ Francis is sometimes considered to have been an iconoclast himself, worshipping only the body and blood of Christ through the sacramental material of the Eucharistic bread and wine rather than venerating sacred images as he prayed. Elviro Lunghi points to Francis' Testament, where Francis declares, "I cannot see the most high Son of God with my own eyes, except for his most holy Body and Blood which they [the priests] receive and they alone administer to others." ${ }^{" 186}$ While Lunghi recognizes that statement was probably said in defense of the doctrine of the Real Presence made explicit by Lateran IV, Lunghi's statement also neglects key events in which Francis reverenced artwork and material mementos of his faith. For example, Francis was inspired to rebuild the Church of San

\footnotetext{
${ }^{184}$ Derbes, Picturing the Passion, 23-24.

${ }^{185}$ Kennedy et al., Sanctity Pictured, 3; Francis et al., Francis and Clare, 155.

${ }^{186}$ Lunghi, "Francis in Prayer," 342.
} 
Damiano following a mystical visual and aural interaction with a crucifix in the church. ${ }^{187}$ He also instructed the friars to make the sign of the cross whenever they encountered a painted or sculpted cross, or even a cross formed by nature, for example two tree branches crossing. Francis himself drew one extant image - that of the order's original habit in the shape of a Tau cross. The sketch survives on the back of a prayer he wrote for one of the early brothers. ${ }^{188}$ Finally, it was reported that Francis himself carried an icon of Mary to the Greek island of Cephalonia. ${ }^{189}$ He clearly did not reject the use of art and material to the same extent as the Perfecti.

While the early brothers strove to live in stringent deprivation, after the death of Francis on October 3,1226, the order gradually adopted a more tempered approach to poverty. Pope Gregory IX released the Franciscan brothers from the austere poverty instituted by Francis when he promulgated the papal bull Quo elongati, which states that the order was permitted to utilize buildings, books, furniture, and decoration that were owned by other people. This allowed the friars to work collaboratively with the papacy, secular governments, and lay people to construct elaborate churches throughout Italy. ${ }^{190}$ Two years following the death of Francis, Pope Gregory assisted the young order in the construction of the basilica that would serve as the saint's tomb, building a pilgrimage

${ }^{187}$ I will discuss Francis' experience in the Church of San Damiano in Chapter 5.

${ }^{188}$ Rona Goffen, Spirituality in Conflict: Saint Francis and Giotto's Bardi Chapel, 1988, 24.

${ }^{189}$ Derbes and Neff, "Byzantine Sphere,” 458.

${ }^{190}$ Kennedy, Cooper, Flora, Neff, Robson, et al., Sanctity Pictured, 4; Lunghi, "Francis in Prayer," 344. 
destination of impressive size and beauty into the hillside of Assisi. ${ }^{191}$ He laid the cornerstone the day following Francis' canonization, which occurred on July 16, $1228 .{ }^{192}$ In 1253 Pope Innocent IV visited Assisi, remaining for six months. Somewhat disappointed in the plainness of the new church, he wrote the bull Decet et expedit which not only permitted abundant decoration of the basilica but also established papal funding for the project. ${ }^{193}$ In defense of the grandeur of the Basilica of San Francesco, Lunghi states, "The splendor of the building should thus not mislead those who want to see in it a betrayal of the apostolic poverty preached by Francis, as it was erected at the express wish of a Roman pontiff with the intention of celebrating the heavenly glory of the saint." 194 Over the following century, the papal basilica of San Francesco evolved into the foundation and critical exemplar of Franciscan art for all of Italy. ${ }^{195}$ Assisi became a magnet and workshop for aspiring artists. ${ }^{196}$

Both in and outside Assisi, the Franciscan order stood as the most prolific patron of the arts in Italy from the thirteenth century through the Renaissance. ${ }^{197}$

${ }^{191}$ Kennedy et al., Sanctity Pictured, 3.

192 Lunghi, “Francis in Prayer,” 344.

${ }^{193}$ Donal Cooper and Janet Robson, The Making of Assisi: The Pope, the Franciscans and the Painting of the Basilica (New Haven: Yale University Press, 2013), 74.

${ }^{194}$ Lunghi, "Francis in Prayer," 344.

${ }^{195}$ Kennedy et al., Sanctity Pictured, 19.

196 Arthur Waldon, "The Influence of St. Francis of Assisi on Mediæval Art," The American Catholic Quarterly Review, American Periodicals, January 1883, 52, http://search.proquest.com.proxy.mul.missouri.edu/docview/1301482309?pq-origsite=summon.

197 Unless noted, information in this section draws from Kennedy, Cooper, Flora, Neff, Robson, et al., Sanctity Pictured, vi, 2, 9. 
The 1230 papal bull that created the arrangement of usus simplex specifically allowed for the decoration of Franciscan churches with suitable artworks. Over time, in Bologna, Florence, Milan, Naples and Siena, the mendicant order's churches competed in size and extravagance with the local diocesan cathedrals. The immensity and beauty achieved in the mid- to late-thirteenth century were due in great part to the admiration and donor-backing the Franciscan order had attained during its early decades. Bradley Franco affirms the importance of these artworks, saying "depictions of the life and miracles of Francis were, together with vernacular preaching, the primary method through which the friars propagated their message and explained the order's mission to the laity."198 The friars' artwork served as a powerful tool to validate the orthodoxy of the Church in the face of heresy.

\section{The History and Spiritual Depth of Wood-Panel Paintings}

In this section, I will briefly address the history and process of wood-panel painting as well as spiritual dimensions associated with the material. Edward B. Garrison, whose Index of Italian Panel Painting (1949) has been the basis of countless studies, estimated that the rate of destruction of thirteenth-century panels falls within the staggering range of $80 \%-99 \% .{ }^{199}$ The extant panel paintings of Tuscan origin surpass the number of all the other regions' products combined. ${ }^{200}$ For the study at hand, I was

${ }^{198}$ Franco, "Functions of Franciscan Art," 19.

${ }^{199}$ Edward B. Garrison, "Note on the Survival of Thirteenth-Century Panel Paintings in Italy," Artbulletin The Art Bulletin 54, no. 2 (1972): 140.

${ }^{200}$ Edward B. Garrison, Italian Romanesque Panel Painting: An Illustrated Index (New York: Hacker Art Books, 1976), 3. 
fortunate to work with ten examples of simple icons, eight vita dossals, and ten monumental crucifixes. Their larger size and comparative protection within friaries and churches that were consistently maintained by the Franciscans until modern times may have assisted the survival rate among these artifacts. Still, it is likely that many more Franciscan painted panels were made, and a great number were lost.

For Christian decoration from the first centuries through the late antique periods, wood appears to have been in limited use. Rather, fresco and mosaic remain in evidence for the significant portion of church adornment. For private image-based prayer, parchment was the preferred support for paintings, and these were usually bound into books. ${ }^{201}$ Portable paintings on wood depicting saints and religious scenes survive in small numbers from the fifth and sixth century on, with a substantial pause during the iconoclastic controversy in the East. These small-scale devotionals proved more affordable than costly metalwork or enamel and more durable than parchment, in addition to being more visually accessible than bound manuscripts. ${ }^{202}$ While fresco remained the method of choice for large architectural decoration, for many artists, the final product of painting on wood surpassed that of the fresco technique. The colors of egg tempera were more vibrant than that achieved by mixing pigments into plaster. The conditions of work could also be controlled by the artists more independently, as they no longer had to work on site; nor were they required to race against the drying plaster of the giornata.

Uncountable craftsmen were required to meet the artistic needs of the Church. Master artists, their names now mostly forgotten, trained apprentices in the techniques of

\footnotetext{
${ }^{201}$ Caroselli, Italian Panel Painting, 10.

202 This section is based on Caroselli, Italian Panel Painting, 10-11, 19.
} 
painting on wood panels in their workshops. The works of this medium exemplify the technical skills common to the age, and in doing so, serve as documentation for how craftsmen learned their trade. Cennino Cennini's fifteenth-century Libro dell'Arte, which made use of the theories and techniques that had been common to Florentine artists for centuries prior, became popular in its day and has served to explain artisan practices since. ${ }^{203}$

First the wood itself is selected. Cennini (c.1360 - before 1427) presents the properties of numerous tree species, but he does not enter into a discussion of how the logs are harvested, milled into boards, dried flat, and often bonded together to the proper dimension and shape. A craftsman known as a legnaiolo would construct the wooden supports for paintings; even working directly with the patron prior to the selection of an artist. In his article, "Historical Overview of Panel-Making Techniques in Central Italy," Luca Uzielli theorizes that this lacuna in Cennini's instructions reveals that these processes fell outside the standard purview of the artist, although there may have been cooperation or consultation between the painter and the legnaiolo. ${ }^{204}$

The panel chosen was often from the poplar tree, although sometimes it was taken from lime (linden), willow, or oak species. ${ }^{205}$ Only the rare tree with a tall, straight trunk could be harvested for this purpose. The boards would be cut from the heartwood, the

${ }^{203}$ Caroselli, Italian Panel Painting, 32; Luca Uzielli, "Historical Overview of Panel-Making Techniques in Central Italy," in The Structural Conservation of Panel Paintings: Proceedings of a Symposium at the J. Paul Getty Museum, 24-28 April 1995., by Kathleen Dardes and Andrea Rothe (Los Angeles: Getty Conservation Institute, 2013), 110; Cennino D’Andrea Cennini and Daniel V. Thompson, The Craftsman's Handbook (New York: Dover Publications, 1960).

${ }^{204}$ Uzielli, “Historical Overview," 111-13.

205 The choice of wood depended on the geography and climate of regions. John Fletcher, "Panel Examination and Dendrochronology," J. Paul Getty Museum Journal / J. Paul Getty Museum, 1982, 39. 
center section, which was quartered and divided again, resulting in eight panels measuring one half to one meter in length and 20 to 40 centimeters in width. Most icons were made of at least two boards glued together with casein glue (made of milk proteins) or an adhesive made from boiling the skins, bones, and connective tissues of animals. ${ }^{206}$ Panel pieces could be increased in scale by attaching multiple planks to one another using dowels or winged wooden joins, called "butterflies." Battens placed perpendicularly across the back provided a gridwork support. ${ }^{207}$ For large crosses, several panels are joined together with long narrow beams using nails and wooden pins (Figure 2.1). The resulting constructions could fill the width and height of a cathedral. Weight was also a factor when creating the wooden supports, with the goal to make them as strong as possible while also lightweight. Wood-panel paintings were regularly carried, not only to transport them from the workshop to their location of display, but also in religious processions and to complement public sermons, a factor that will prove instrumental in Franciscan evangelization. ${ }^{208}$

Once the support has been constructed and is in the workshop of the artist, Cennini meticulously lays out his plan for the training of a student to paint on wooden panels. Having already mastered the skills of drawing with various media, working with numerous pigments, and the methods of fresco and oil painting, the student eventually arrives at the elaborately detailed instructions for the dipintura process, as follows: The

${ }^{206}$ Fletcher, "Panel Examination,” 41; Uzielli, "Historical Overview," 118-19.

${ }^{207}$ Caroselli, Italian Panel Painting, 11, 19.

${ }^{208}$ Fletcher, "Panel Examination," 39; Franco, "Functions of Franciscan Art," 21; Uzielli, “Historical Overview," 118. 
wood is planed to make the flats or ancona. It must be free of knots and scraped perfectly smooth. Imperfections, when unavoidable, may be repaired with a mixture of sawdust and boiled glue. ${ }^{209}$ The joints or seams are covered with damp linen or canvas, and the entire composite panel and framework are wrapped in overlapping linen sheets (Figures 2.2-2.3). ${ }^{210}$ This ground layer adheres to the wooden board with gesso and animal glue sizing, which consists of parchment clippings boiled down to a thick paste. After this has thoroughly dried, it is scraped and sanded. At this point, Cennini says that architectural and ornamental decorations may be included such as "foliage ornaments, canopies, [and] little columns" molded from plaster (Figure 2.4). ${ }^{211}$ Through numerous stages the board is covered in layers of gesso, scraped until smooth, dried and then scraped again. This process is repeated with an increasingly finer solution of gesso grosso and gesso sottile until it reaches the complexion of ivory. In Cennini's words, the board "cannot be scraped down too perfectly."212

A stick of willow charred at the tip is used to make a preliminary sketch on the white board. The sketch is then reworked and details added with a squirrel-hair paint brush and the original charcoal drawing is erased with a feather brush, leaving only a shadow. The gesso is incised with a needle to delineate where the gold leaf will be placed. To gild the background, a very fine clay, mixed with egg white and water (the

${ }^{209}$ Umberto Baldini and Ornella Casazza, The Crucifix by Cimabue (Italy: Olivetti, 1980), 12; Cennini and Thompson, Craftsman's Handbook, 69-70.

${ }^{210}$ Uzielli, “Historical Overview,” 113.

${ }^{211}$ Unless noted, this section is drawn from Cennini and Thompson, Craftsman's Handbook, 6976.

${ }^{212}$ Cennini and Thompson, Craftsman's Handbook, 74. 
combination known as bole) is applied around the figures. The gold leaf is applied in small sections to the damp surface and pressed with a cotton or wool cloth to achieve adhesion; the red hue of the bole casting a warm glow through the semi-transparent gold leaf. The rough gilding is then burnished with a dog's tooth or stone to create an even, gleaming sheen. Decoration can be added by metal tooling with a compass, sharp edge, or stamp (Figure 2.5).

The tempera paint is made of mineral or organic pigments added to egg yolk in a process Cennini describes thoroughly in his second chapter. This medium dries so quickly that three variations of each color are made in light, mid-tone, and dark. The paint is applied through hatching thin lines, layer over layer, until the desired color variation is achieved. Landscape and draperies should be painted first, followed by the flesh of any figures. Once the paint is thoroughly dry, one or more coats of linseed oil varnish may be applied to protect the finished surface and bring out the depth of the colors.

Cennini's exhaustive directions indicate the control and expertise present in medieval artists' workshops in which these panel paintings were created, codified after centuries of tradition. While focusing extensively on technical skill, Cennini does not omit the intellectual and emotional (even spiritual) process required to develop into a master: He believes the artist must live as if he is a faithful scholar-adopting a rigorous discipline for both mind and body. ${ }^{213}$ Their work must be methodical and in tune with nature and the seasons. In addition to the precise technical direction, Cennini imbues his

\footnotetext{
${ }^{213}$ Andrea Bolland, "Art and Humanism in Early Renaissance Padua: Cennini, Vergerio and Petrarch on Imitation," Renaissance Quarterly 49, no. 3 (1996): 470, https://doi.org/10.2307/2863363.
} 
instruction with devotion and humanity. He tells his fellow artist, "Your life must be organized as if you were studying theology or philosophy or some other science."214

In comparison to the Franciscans, the Cathars rejected the Catholic use of created artwork as a source of belief. A tenet of ascetic groups such as theirs was a disdain for religious artifacts and relics. ${ }^{215}$ The Cathars followed in an active heritage of antimaterialists based in Eastern iconoclasm. ${ }^{216}$ From the fourth century, it was held that spiritual power remained active in the bodies of saints-their relics. Over the course of the next two centuries in eastern Christianity, though not in the West, this power extended to the saints' crafted images. ${ }^{217}$ Leslie Brubaker asserts these icons were "intended to preserve the memory of the person represented, to provide an inspiring model for imitation, to honour the figure portrayed, or to express thanks to a saint who has answered a prayer." ${ }^{218}$ In the Byzantine empire, from the early seventh to the midninth century, this controversy simmered regarding the use of images for religious devotions. Textual references discouraged venerating or decorating icons as "pagan" practitioners did. However, in the 690s, the sources reveal that the practice had shifted to mirror the veneration that was used for relics - treating images with lit candles, incense, and sacred spaces set apart with curtains. It was at this point in the late seventh century,

214 Baldini and Casazza, Crucifix by Cimabue, 11

${ }^{215}$ Lambert, The Cathars, 12.

${ }^{216}$ Hans Belting, Likeness and Presence: A History of the Image Before the Era of Art (Chicago: University of Chicago Press, 1994), 268.

${ }^{217}$ Unless noted, information in this section is drawn from Leslie Brubaker, Inventing Byzantine Iconoclasm (London: Bristol Classical Press, 2012), 3-4, 9-10, 13-14, 16-17.

${ }^{218}$ Brubaker, Inventing Byzantine Iconoclasm, 13. 
that the earliest regulation of religious imagery was enacted by the eastern Church, reflecting the existence of a popular belief in the spiritual power of icons and a corresponding devotional practice. Over the following century and a half, a tug-of-war ensued between those who supported the use of figural images and those who condemned it. Ecclesial hierarchy, emperors and empresses, and military leaders appeared in the ranks of both sides. ${ }^{219}$ The iconophiles at the Quinisext Council (691/2) decreed that Jesus should be represented in bodily form rather than symbolically, as in the traditional image of a lamb. ${ }^{220}$ For the iconoclasts, the Synod of 754 ordered:

Christ, the Virgin and the saints could not be represented in images for two distinct reasons. First, portraits of Christ would separate his human from his divine nature; and, secondly, portraits of the Virgin and saints insulted their memories, for they lived eternally beside God. Instead...the eucharist was the only true image of the divine dispensation which is Christ. ${ }^{221}$

Speaking about the materiality of icons, orthodox clergy in the East defended the use of pigments, making the analogy that the figural image is to the written word as the New Testament is to the foreshadowing of Christ in the Hebrew scriptures. Quoted in Herbert Kessler's Spiritual Seeing, the ninth-century Byzantine theologian Methodius questioned, "Why might one not describe Jesus Christ our Lord with the brilliance of colors as legitimately as with ink? He was never presented to us as of ink, but was manifested as a true man, truly endowed with form and with color.” But the Iconoclasts

${ }^{219}$ Brubaker, Inventing Byzantine Iconoclasm, 22-26.

${ }^{220}$ Pallis, Dimitrios. “A Critical Presentation of the Iconology of St. John of Damascus in the Context of the Byzantine Iconoclastic Controversies.” Heythrop Journal 56 (2): 173-91 (2015) 177.

${ }^{221}$ Brubaker, Inventing Byzantine Iconoclasm, 33. 
took the opposite opinion, claiming that the pulverized minerals and organic material that gave paints their color was "dead matter unworthy of association with God."222

Intertwined with this Christian history is the role of Islam, which arose in the seventh century. Although the complexities of Islamic theology, culture, and migration are beyond the scope of this study, it is necessary to recognize that Islam, like Catharism, is an aniconic faith—rejecting representations of God, humans, and animals in religious artwork. During the seventh century, a third of the Byzantine Empire's territories were lost to Muslim control. While Christians continued to live and practice their faith in these regions with little interference beyond additional taxation, the impact of Islam can be observed in the historical record. ${ }^{223}$ Orthodox theologians worked to prevent "cultural assimilation" of Christian communities in western Asia and northern Africa. It is probable that these theologians' justification for and promotion of sacred images was a reaction to Muslim beliefs. ${ }^{224}$ John of Damascus (c. 675-749) explains the relationship between Christian devotion to images and the Incarnation of Jesus, an idea that formed the core of the iconophiles' position. He asserts that "there should not be any fear of the snare of idolatry among Christians, since the Word has become flesh, thus fulfilling the spirit of the Law of the Old Testament, and has therefore become a proper subject for iconographic treatment."225 This belief was ratified by the Byzantine Church in the

${ }^{222}$ Herbert L Kessler, Spiritual Seeing: Picturing God's Invisibility in Medieval Art (Philadelphia: University of Pennsylvania Press, 2000), 55-56.

${ }^{223}$ Brubaker, Inventing Byzantine Iconoclasm, 15-16.

${ }^{224}$ Pallis, "Iconology," 175.

${ }^{225}$ Pallis, “Iconology," 177. 
following century and was later put to use by the thirteenth-century Franciscans. The theologians Alexander of Hales (c. 1185-1245) and Bonaventure adopted John of Damascus' iconology when discussing the veneration of images of Jesus, confirming that "The honor paid to the image is referred to the prototype."226 John of Damascus goes on to affirm the sanctity of all creation, stating, "I reverence the rest of matter and hold in respect that through which my salvation came, because it is filled with divine energy and grace. 227

The Cathars rejected the notion that the created world could be sanctified in any way. Carol Lansing asserts, "In a period marked by a new naturalism and emphasis on the spiritual possibilities of the created order, Cathars preached a flat denial." ${ }^{228}$ Despite the dearth of textual sources explicating their thoughts on visual art, it follows that they would have rejected the icons and crucifixes that the Franciscans used to promote the Catholic cause. ${ }^{229}$ The wooden boards, the animal glue, the precious gold leaf, the base metal hardware, the egg tempera paints - all the elements of a wood-panel painting - the Cathars would have held in contempt.

In comparison, an orthodox viewer would have acknowledged the material yet felt moved to love and greater understanding by the divine prototype beyond the image, as the twelfth-century Benedictine monk Rupert of Deutz described his state of mind while

${ }^{226}$ John of Damascus, quoted in Derbes and Neff, "Italy, the Mendicant Orders, and the Byzantine Sphere," 459.

${ }^{227}$ John of Damascus, quoted in Pallis, “Iconology,” 179.

${ }^{228}$ Lansing, Power and Purity, 8-9.

${ }^{229}$ Lambert, The Cathars, 17. 
gazing upon a crucifix: "While we externally image forth [Christ's] death through the likeness of the cross, we [are kindled] inwardly to love of him." ${ }^{230}$ Cennini placed his work within orthodox Catholic belief structures when he closed his Craftsman's

Handbook with a prayer invoking Francis of Assisi, among other saints, asking for their blessing on himself and his student readers. ${ }^{231}$

The formation of both artwork and artist, in the techniques described by Cennini, was already traditional for the mostly anonymous thirteenth-century craftsmen employed by the early Franciscans. But for the Friars Minor, the process of transforming natural materials into sacred artwork may have held a deeper meaning derived from Francis' charism and writing that glorified God's creation. In modern times, Francis is considered the patron saint of the environment. ${ }^{232}$ While in so many ways, the poor man of Assisi can be compared to the Cathar Perfecti, in his adoration of nature Francis stands as the antithesis of the Cathar movement.

In his seminal volume, The Limewood Sculptors of Renaissance Germany, 14751525: Images and Circumstances, Michael Baxandall touches on the animistic spirituality that may have laid the deep underpinning for Francis' ecological leanings. When discussing the limewood trees sourced for sacred sculpture in Germany, Baxandall claims that this wood:

${ }^{230}$ Sara Lipton, "'The Sweet Lean of His Head': Writing about Looking at the Crucifix in the High Middle Ages," Speculum 80, no. 4 (2005): 1179-82.

${ }^{231}$ Cennini and Thompson, Craftsman's Handbook, 131.

${ }^{232}$ He was officially named as such by Pope John Paul II in 1979, Vatican News, "Pope Consecrates Synod for the Amazon to Saint Francis of Assisi," October 4, 2019, https://www.vaticannews.va/en/pope/news/2019-10/pope-synod-amazon-saint-francis-vaticangardens.html. Francis' relationship to nature will be discussed further in Chapter 4. Also see Francis' Canticle of the Creatures (Appendix 6). 
...had a more elusive distinction of a kind one cannot either measure or entirely ignore. In Germany the lime, like some other trees, was an object of magico-religious interest. This is reflected in a certain ambiguity in the word Linde in Early New High German: it is used for holy grove as well as 'limetree'... The background to this is a surprising range of rather folkloristic practices. There are reports of holy limetrees hung with votive tablets against the plague; of many limegroves visited as places of pilgrimage; of lime seeds eaten by the pregnant women of upper Bavaria; of the leaves, blossom and bark of the tree applied to the body as a means to strength and beauty... it is uncomfortably fugitive material and it may even be better to leave it aside. What is clear is that the lime did have, broadly speaking, festal associations: as Hieronymus Bock said, it was a tree to dance under. Limewood was no base material but one to be respected: a way to see the carver's treatment of it is as active respect. ${ }^{233}$

Rather than "leaving it aside," let us briefly explore Francis' own significant relationship to a sacred grove and consider the wood-panel icons created by the Friars Minor as incorporating a kind of "active respect."

The grove in this case consists mainly of holm-oak trees, Quercus ilex, and it still stands on the site of Monteluco, southeast of the town of Spoleto. The common name is believed to be drawn from the Anglo-Saxon word for holy. Today the 4.6 square kilometer area of the grove is preserved by the European Commission as a conservation zone. During Roman times, the forest was consecrated to the god Jupiter. It contains the earliest known environmental law, the Lex Lucis Spoletina, carved on a third-century BCE stele which forbids the harvesting of holm-oaks. The punishment for cutting a tree requires a sacrifice of an ox to Jupiter (Figure 2.6). ${ }^{234}$

${ }^{233}$ Michael Baxandall, The Limewood Sculptors of Renaissance Germany, 1475-1525: Images and Circumstances (New Haven: Yale University Press, 1980), 31.

${ }^{234}$ The current stele is a replica, replacing the original that was moved to the Spoleto Archeological Museum. Information and quotes in this section are sourced from Rete Natura $2000 \mathrm{Il}$ Progetto Siti Natura 2000 del Comune di Spoleto, "Signage at Monteluco," 2000. 
Centuries after this Roman pronouncement, monks from Syria sought refuge on the mountain, establishing a hermitage among the natural caves of Monteluco. Benedictine monks eventually took over the foundation; and in 1218, they provided Francis and his brothers with the use of a small chapel, a water well, and several hermitage cells, one of which was also used by Antony of Padua (all still extant). The site eventually was turned over to the Franciscan brothers who established what is known today as the Sanctuary of Saint Francis. Novices are still encouraged to live in the rustic property during their early years of formation. The grove of Monteluco was a favorite location for Francis to wander in the midst of nature. An escarpment that tradition says Francis would frequent near the legal stele provides a breath-taking view. A carving at the site provides a quote from the saint that reveals his love of the area: "Nihil iucundius vidi valle mea spoletana [Never did I see anything more joyful than my Spoleto valley] (Figure 2.7)."

Beyond the Roman polytheistic aura of the sacred holm-oak forest, Francis, who embraced the study of the bible, could have drawn from the Old Testament to justify his appreciation for the region, covered in ancient oaks. From Genesis, it is written that Abram moved his tent to live near the oaks of Mamre, building an altar to God there (Genesis 13:18). And at the oak tree at Schechem, Jacob buried the foreign idols his people had adopted (Genesis 35:4). In a passage reminiscent of the Lex Lucis Spoletina, the book of Joshua reads: "Josue therefore on that day made a covenant, and set before the people commandments and judgments in Sichem. And he wrote all these things in the volume of the law of the Lord: and he took a great stone, and set it under the oak that was in the sanctuary of the Lord." (Joshua 24:25-26) 
The connection between the giant holm-oak species and Francis is also evidenced by a Quercus ilex in Lecchio delle Ripe, Tuscany, which is believed to have shaded the saint as he preached and rested. Pilgrims continue to venerate the area, processing to the eight-century-old tree and decorating it with crosses and votives. To this day, the holmoak is held sacred by the Franciscan order, and the presence of friaries near ancient sacred groves has served to protect the species. ${ }^{235}$ Having chosen his name to honor and emulate the poverello, the current leader of the Catholic Church, Pope Francis, recently planted a holm-oak in the Vatican Gardens. This transplanting of a tree from Assisi commemorated the opening of the ecologically focused Synod of the Amazons in the Fall of $2019 .^{236}$

While the oak tree is not listed among the preferred species for panel painting by Cennini, numerous icons made use of this ubiquitous plant. Throughout history and across cultures, trees in general have been understood as bearers of spiritual properties. The historian of religion Mircea Eliade explains that often trees are held to be sacred not as a matter of roots, trunk, branches, and leaves, but rather they are considered a hierophany. Eliade describes a hierophany as ganz andere: something completely different from the ordinary. He explains a hierophany further: "By manifesting the sacred, any object becomes something else, yet it continues to remain itself, for it

${ }^{235}$ Fabrizio Frascaroli, "Catholicism and Conservation: The Potential of Sacred Natural Sites for Biodiversity Management in Central Italy,” Humanecology Human Ecology 41, no. 4 (2013): 594.

${ }^{236}$ Vatican News, "Pope Consecrates." 
continues to participate in its surrounding cosmic milieu. ${ }^{237}$ In the Christian paradigm, trees represented the original tree - the archetype of the tree- believed to be both the Tree of Wisdom from the Garden of Eden and the tree used for the Cross of Christ. Drawing from their natural state, the wood-panel paintings of the Church served as a hierophany for the sacred Christian images they represented while at the same time retaining the ancient spiritual vitality of their organic and archetypal source. ${ }^{238}$ Although Francis did not emphasize living trees in his writings, both he and the early Franciscans treated the Wood of the Cross of Jesus as a major topic in their texts and their artwork, an axis mundi connecting the earth to the heavens.

In the same way, throughout the art and theology of writing sacred icons, each natural element of the craft participates in a deeper spiritual meaning. For example, the egg used to mix tempera paint has symbolized fecundity and rebirth for centuries even before Christianity. The linen that wraps the wooden icon panel to provide a substrate for the gesso also serves as a reminder of the shroud that covered Jesus' body in the tomb. The linseed oil has connotations of anointing, rich in scriptural and sacramental usage. Each physical component serves as a locus of contemplation for the iconographer, who fasts and prays for the duration of the icon's creation. ${ }^{239}$

${ }^{237}$ Hierophany from the adjective hieros (Greek: iєpóc; sacred/holy) and the verb phainein ( aivesv; to reveal/to bring to light. Mircea Eliade, Images and Symbols: Studies in Religious Symbolism (Princeton, N.J.: Princeton University Press, 1991), 12.

${ }^{238}$ For an explanation of the concept of the axis mundi in multiple cultures, see Eliade, Images and Symbols, 161-64.

${ }^{239}$ Information in this section is drawn from conversations with master iconographer, Rev. Paul Czerwonka, American College, Katholieke Universiteit, Leuven, Belgium. April 2010; For further information regarding the religious dimensions of icons, see Léonide Ouspensky and Vladimir Lossky, The Meaning of Icons (Crestwood, NY: St. Vladimir's Seminary Press, 1999); Henri Nouwen, Behold the Beauty of the Lord: Praying with Icons (Notre Dame, IN: Ave Maria Press, 2007). 
Following the lifetime of Francis, we can look to the theologian Bonaventure for the explosive proliferation of visual and material works under the guidance of the order. Along with his administrative duties as minister general of the Order of Friars Minor, Bonaventure also turned his attention to teaching about sacred images, providing theological explanations for devotional practices that were currently in use. ${ }^{240}$ Bonaventure supported using artwork to enhance the congregation's understanding of scripture and church teachings. ${ }^{241}$ In his brief but complex work, On the Reduction of the Arts to Theology, Bonaventure explains how all knowledge can be connected to theology (See Appendix 2 for relevant sections). ${ }^{242}$ Embracing a metaphysical philosophy in which light is the highest form of created matter and is the basis for beauty, color, and action, Bonaventure understood all created light to emanate from the primal light of Truth, which is God. Bonaventure sees all creation as saturated with this supernal light —-therefore with the image of God. The only manner in which humans may gather knowledge is through the senses. The sense of sight provides access to "luminous and colored bodies."243 Material images, when received by the eyes, create delight in the viewer. For the medieval person, this enjoyment was based on the Greek tradition of order and

${ }^{240}$ Neff, "Painting, Devotion, and the Franciscans," 34.

${ }^{241}$ Kennedy et al., Sanctity Pictured, 8.

${ }^{242}$ Explanations were drawn from Zachary Hayes' "Commentary on the Text" in Bonaventure and Zachary Hayes, St. Bonaventure's on the Reduction of the Arts to Theology, Works of Saint Bonaventure (St. Bonaventure, N.Y: Franciscan Institute, St. Bonaventure University, 1996), 2-17. Bonaventure, De Reductione Artium Ad Theologiam: A Commentary with an Introduction and Translation by Sister Emma Thérèse Healy. (Saint Bonaventure, N.Y.: St. Bonaventure University, 1955), 31-35, https://archive.org/details/dereductionearti0001bona.

${ }^{243}$ Hayes, quoted in Bonaventure and Zachary Hayes, St. Bonaventure's, 17. 
proportion. The more closely the image was considered to be in congruence with the "first image" of God (the incarnate Word), the more beautiful it was believed to be. Art, according to Bonaventure, takes the physical form of the archetype created within the mind of the artist. He sees this as analogous to the work of creation by God and believes the divine can shine through the artifacts created by craftsmen. ${ }^{244}$ Bonaventure states, ...all the creatures of the sense world lead the mind of the contemplative and wise man to the eternal God. For these creatures are shadows, echoes and pictures of that first, most powerful, most wise and most perfect Principle, of that eternal Source, Light and Fulness, of that efficient, exemplary and ordering Art. They are the vestiges, representations, spectacles proposed to us and signs divinely given so that we can see God. ${ }^{245}$

This is a philosophy directly opposed to the Cathars' conception of evil materiality. Bonaventure believes art should have the qualities of being "beautiful, useful, and enduring." ${ }^{246}$ It should delight the viewer, cause the viewer to ponder it and find goodness and honesty therein. ${ }^{247}$ In the reflection of the Incarnation of God within artworks, Bonaventure acknowledged great agency in the artifacts created for the purpose of doctrinal education. He encourages the use of art, saying, "Behold how the illumination of mechanical art is the path to the illumination of Sacred Scripture. There is nothing therein which does not bespeak true wisdom and for this reason Sacred Scripture

\footnotetext{
244 Bonaventure and Zachary Hayes, St. Bonaventure's, 25, 49.

${ }^{245}$ Bonaventure and Cousins, Bonaventure: Soul's Journey, 75-76.

246 Bonaventure and Zachary Hayes, St. Bonaventure's, 51.

247 Bonaventure and Zachary Hayes, St. Bonaventure's, 26-27, 51.
} 
quite rightly makes frequent use of such similitudes." ${ }^{248}$ Bonaventure encouraged his brothers to reveal the deception of heresy as an essential method of educating the laity in true Christian beliefs and morality, according to the teachings of the Church. ${ }^{249}$ In the next chapters, we will look at specific wood-panel paintings that put Bonaventure's philosophy into tangible and visible practice, allowing the early Franciscan community to promote their founder as a preacher of orthodoxy in defense against the Cathars, considering first the simple portrait icons of Francis and the impact of representations of his stigmatization (Figure 2.8).

${ }^{248}$ Bonaventure, De Reductione Artium Ad Theologiam: A Commentary with an Introduction and Translation by Sister Emma Thérèse Healy. (Saint Bonaventure, N.Y.: St. Bonaventure University, 1955), 31-35, https://archive.org/details/dereductionearti0001bona.

${ }^{249}$ Wakefield, "Treatise Against Heretics," 224-25. 


\section{Chapter 3: Icons of Francis as Orthodox Exemplar in Opposition to the}

\section{Cathar Perfecti}

The art historical literature presents several viable theories for the rapid and widespread proliferation of imagery of Francis in the thirteenth century. Rona Goffen offers the most straightforward of reasons for this production — artwork was employed to educate members of the Church about Francis' biography and his seemingly miraculous deeds performed during his life and posthumously. ${ }^{250}$ William Cook, in addition, considers the practical need for the early friars to grow their fledgling order by informing and inspiring the laity through images of Francis' sanctity. The brothers intended to spread the word that the saint's newly constructed tomb in Assisi was a powerful and holy pilgrimage destination. ${ }^{251}$ In this way, Cook explains, the friars endeavored not only to illustrate their founder, but also to claim an identity for their new religious order: "who they were and what their role was in the life of the church and, for that matter, in the entire history of salvation." 252 Another rationale was to publicize Francis as a thaumaturge. Even before his death in 1226 and canonization in 1228, Francis was recognized as a powerful healer. ${ }^{253}$ After his death, pilgrims venerated his body and objects he had touched. Traditionally, relics and contact relics of saints were sought to alleviate physical or spiritual suffering. However, quite recently before Francis' death,

${ }^{250}$ Goffen, Spirituality in Conflict, 13.

${ }^{251}$ Cook, "Fraternal," 270.

${ }^{252}$ Cook, "Fraternal," 265.

${ }^{253}$ Rosalind B. Brooke, The Image of St Francis: Responses to Sainthood in the Thirteenth Century (Cambridge: Cambridge Univ. Press, 2009), 164-65. 
the Church had forced a change in the use of relics. The Fourth Lateran Council, Canon 62 , aimed to reduce the proliferation of illegitimate relics by requiring new relics to be verified by the Vatican and curtailing the exhibition and sale of existing relics. ${ }^{254}$ To this end, Hans Belting recognizes the early Franciscans' promotion of their founder's painted image as a transition from the reverencing of relics to the veneration of icons in the western Church. ${ }^{255}$ The brothers intended the visual imagery of Francis to spread. Goffen points out that the reproduction of Francis' visage allowed for physical veneration of the saint to take place geographically beyond Assisi through his icon. ${ }^{256}$ Paintings of Francis became considered effective tools of intercession. Herbert Kessler writes that on Francis' feast day in 1265, a friar preached a sermon explaining that "the homage paid to a painted portrait is equivalent to veneration of the saint himself." ${ }^{257}$ It is conceivable that the friar declared this while steering the crowd's attention to an actual image of Francis.

While all these reasons serve to explain a large part of the phenomenon, one other cause for the production and diffusion of so many images of Francis should also be considered: that the saint's image was used as an instrument to promote orthodox Christian beliefs, particularly in order to counter the Cathar heresy. In this chapter, I will examine specifically the manner in which the early minorites used the image of Francis to

254 "Fourth Lateran Council: Internet Medieval Sourcebook. Hanover College," accessed March 11, 2016, http://history.hanover.edu/courses/excerpts/344lat.html.

255 Belting, Likeness and Presence, 308.

${ }^{256}$ Goffen, Spirituality in Conflict, 13.

${ }^{257}$ Herbert L Kessler, Seeing Medieval Art (North York, Ontario: University of Toronto Press, 2011), 156. The identity of the preacher or location of the sermon mentioned could not be determined by the present author. Kessler cites Krüger, Klaus. Die frühe Bildkult des Franziskus in Italien: Gestalt- und Funktionswandel des Tafelbildes im 13. und 14. Jahrhundert. Berlin: Mann. 1992. 
promote their founder as an alternative to the Cathar Perfecti, presenting Francis as a

paradigm for ascetic orthodox preachers and even as a second Christ.

We have two brief contemporary accounts of Francis' physical appearance. The

first is by Thomas of Spalato, a secular clergyman, who offers a recollection of the saint

whom he saw in person in August of 1222:

When I was studying in Bologna, I saw St Francis preaching in the piazza in front of the Palazzo Pubblico, where almost all the citizens had gathered...He did not deliver his sermon in the usual way, but in a rousing fashion... His habit was dirty, his appearance contemptible and his face illfavoured, but God gave the man's words such effect that many noble clans, whose violence and long-standing feuds had raged with much blood-letting were induced to agree to peace. So great were the reverence and devotion of the people for him that men and women pressed on him in throngs in their eagerness either to touch the hem of his garment or to carry off a scrap of his clothing. ${ }^{258}$

The second description comes from Thomas of Celano's first biography, commissioned

in 1228 by Pope Gregory IX (r. 1227-1241). Also given by an eye-witness, this text

depicts Francis as:

...very eloquent, with a cheerful appearance and a kind face; free of laziness and arrogance. He was of medium height, closer to short, his head was of medium size and round. His face was somewhat long and drawn, his forehead small and smooth, with medium eyes black and clear. His hair was dark; his eyebrows were straight, and his nose even and thin; his ears small and upright, and his temples smooth...His teeth were white, well set and even; his lips were small and thin; his beard was black and short, his hands slight, his fingers long and his nails tapered. He had thin legs, small feet, fine skin and little flesh. His clothing was rough, his sleep was short, his hand was generous. (I Celano, Book 1, Chapter XXIV) ${ }^{259}$

${ }^{258}$ Brooke, Image of St Francis, 160-61; Goffen, Spirituality in Conflict, 95.

${ }^{259}$ Thomas et al., Francis Trilogy, 93. Thomas of Celano's works will be cited as follows through this study: Vita Prima or The Life of Saint Francis as I Celano, the Vita Secunda or The Remembrance of the Desire of a Soul as II Celano, and the Treatise on the Miracles of Saint Francis as III Celano. 
Neither account idealizes Francis' appearance, while both also relay aspects of his personality and behavior.

In addition to directing Thomas of Celano to write the Vita Prima, Pope Gregory IX also commissioned the earliest known visual depiction of Francis to be painted in his private chapel at the Benedictine Monastery in Subiaco, Italy (Figure 3.1). ${ }^{260}$ The fresco's inscription dates this to the second year of Gregory's rule, between 19 March 1228 and 18 March $1229 .{ }^{261}$ The panel paintings examined in this study follow the same basic formula established at Subiaco, though painted with tempera on wood rather than fresco (See Catalog 1 for data regarding these panels). Each panel shows the saint in full length, most often against either an empty gold background or a colored rectangular indication of a floor. The ten simple panel icons measure between 95 to 129 centimeters in height, and 37 to $58.5 \mathrm{~cm}$ in width. In addition, the same iconography informs the large central panels of the composite vita dossals examined in the next chapter, which also incorporate additional narrative scenes. Each icon shows Francis wearing a habit and holding a book. ${ }^{262}$ There is wide disagreement regarding dates of production for specific panels, but the range falls between the years 1235 to the 1290 s.

Of the ten simple icons of Francis I discuss in this chapter, two are held in the Museo della Porziuncola inside the Basilica di Santa Maria degli Angeli in Assisi: one

${ }^{260}$ Pope Gregory IX, whose birth name was Ugolino dei Conti di Segni di Anagni, had known Francis personally as the Cardinal Protector of the Order of Friars Minor from 1216 to his death in 1241.

${ }^{261}$ Brooke, Image of St Francis, 161; Goffen, Spirituality in Conflict, 14, 79.

262 This exhibits a slight change, as the fresco portrait at Subiaco holds a scroll rather than a book. The scroll reads FR[ATER] FRA[N]CISCU[S] and PAX HUIC DOMUI = Brother Francis. Peace to this house. 
painted by the artist known as the St. Francis Master and the other by Cimabue or a close follower. The Louvre has another icon by an anonymous Roman artist. Dispersed among seven Italian collections are five dipinti made by an artist named Margarito d' Arezzo and an additional two that were completed by his workshop or followers during the thirteenth century. ${ }^{263}$ The panels by Margarito can first be considered as a set as they bear only minimal variation. Regarding their consistency, each panel related to this artist shows Francis engaging the viewer with a straightforward gaze. He wears a thin beard and moustache, with a tonsured head beneath a capuche (hood). His eyebrows are thick over large brown eyes. The nose is long and thin, as described by Thomas of Celano; and his mouth is also narrow. All the icons bear an inscription naming Margarito as the artist except the example from San Francesco a Ripa, which has been heavily overpainted.

William Cook recognized three stages in Margarito’s iconography that evidences a chronology for these paintings. In the earliest icons, which Cook dates to the 1230s or 1240s, Francis carries an undecorated book and bears wounds of the stigmata as simple black marks, but only in his hands and feet. The color of paint used for the poverello's habit changes over time. In the earliest of Margarito's examples, Francis wears a black habit as the friars originally did. The General Chapter of Narbonne in 1260 gave the simple instructions that the fabric of the habit should be undyed which, in actuality,

${ }^{263}$ Scholars differ in their opinions of dating and which panels are authentically by Margarito d'Arezzo, and which are by his workshop. Cook assembles the chronology of the extant works of Margarito d'Arezzo and panels associated with his workshop, proposing a revised dating for several of the panels. Margarito's prototype for Francis would continue to be used in later years as well. Unless noted, information regarding the icons in this section is from Cook, "Margarito d'Arezzo's," 83-86. 
resulted in a mottled dark gray fabric. ${ }^{264}$ The brown habit for which the Franciscans are now recognized did not become conventional, for wearing or in illustrations, until after this council. ${ }^{265}$ At the waist, the habit is cinched with a rope punctuated by three to seven knots. ${ }^{266}$ Beneath the hem, Francis' bare feet point downward in an unrealistic perspective, allowing the viewer to witness the nail wounds of the stigmata on their top surface.

Close analysis reveals that hands other than Margarito's worked with these paintings over the centuries. The wood panels containing brown-robed figures, such as that originally from Sargiano, held now in Arezzo, were evidently repainted to change a black habit to brown (Figure 3.2) ${ }^{267}$ The length of the capuche also shows evidence of overpainting on the panels in the Vatican Pinacoteca, Castiglion Fiorentino, Siena, and both Arezzo icons, with later artists changing the hood of the friars' habit from long and pointed to a truncated, rounded version. The tunic may also have been lengthened to the ankle - the differentiation in the floor background indicating the prior length in the Vatican and Montepulciano copies, although this is less certain (Figure 3.3) ${ }^{268}$ The

${ }^{264}$ Cook, 88; Alejandra Concha Sahli, The Meaning of the Habit: Religious Orders, Dress and Identity, 1215-1650 (London, UK, University College London, 2017), https://discovery.ucl.ac.uk/id/eprint/1546082/1/Concha_Alejandra_PhD_Thesis2017.pdf.

${ }^{265}$ Cook, “Margarito d'Arezzo’s,” 84-85.

${ }^{266}$ First Order Franciscans now wear three knots tied in their cord to symbolize their vows of poverty, chastity, and obedience. However, this attribution of meaning appears to be a later development as I found no mention of the symbolism or number of the knots in the literature.

${ }^{267}$ Cook, “Margarito d'Arezzo’s,” 86.

${ }^{268}$ Additional length may have been added following the decision by Pope John XXII (r. 13161334) in which the length of the friars' habit was extended to floor length. Zuppante, "L'Eresia Nella Tuscia," Par. 5. 
timeframe for these amendments is unclear, but most likely they lie beyond our thirteenth-century study. Nevertheless, the changes relay controversies of identity that occurred in the early stages of the order, manifesting in the religious habit that Francis himself designed. For example, in 1317, Pope John XXII responded to a faction of brothers known as the Spirituals, who, beginning in the 1240s, claimed their austere way of life conformed more strictly to Francis' standard. The Spirituals changed their habit to an abbreviated tunic, which the papal bull derided as "short, tight, unusual, and dirty."269 The painted transitions in the hoods and tunics, which may have been altered repeatedly, attempted to assure the viewer that the panel images aligned with Francis' example and the authority of the Church. The changes also ensured that the painted figure remained identifiable as a friar according to the Franciscans' contemporary appearance.

While Francis holds a codex in each of the images, its depiction varies appreciably. In all but one painting attributed to Margarito d'Arezzo, the book is closed. It has either a red or a gilded metallic cover that is decorated in floral and geometric designs, or it is tooled with a cross. In this era, the representation of a saint holding a book is an unusual detail that will be examined more closely later in the chapter. The addition of a decorative cross to the codex is the indicator of Cook's second group of icons, dated from the 1240s or early 1250s. Cook believes the book's cross motif reinforces the saint's stigmatization and also removes any doubt that the text held by Francis is the gospels. It confirms for the audience that the saint is dedicated to the Good

${ }^{269}$ Sahli, Meaning of the Habit, 231-32; For an examination of this mendicant sect, see David Burr, Spiritual Franciscans: From Protest to Persecution in the Century After Saint Francis (Penn State Press, 2010). 
News of Christ. ${ }^{270}$ In three of the icons related to Margarito, Francis also holds a simple cross, sometimes with a short stem. This cross connotes the third grouping of Cook's iconographic differentiation, which he dates from the mid-1250s to early 1260s. The remaining seven simple icons of Francis depict the saint with his right hand raised, palm facing forward. This gesture again showcases the stigmata which will be addressed more fully later in this chapter.

Moving beyond the group by Margarito and his workshop, the remaining images also bear much resemblance to these first icons regarding their composition and iconographic elements: habit, text, stigmata, cross. Whether composed as a simple portrait or a larger panel with a central image of Francis surrounded by a collection of narrative scenes, all these panel paintings isolate Francis as an important and holy figure in the style of Byzantine sacred art. Hans Belting calls Italian panel painting the "heir to the icon." ${ }^{271}$ The Byzantine tradition of panel painting was relatively unused in Italy until the thirteenth century, when it became widespread beginning in the 1230s and 1240s and continuing through the century. ${ }^{272}$ Although the Byzantine Empire had passed its zenith, its skilled craftsmen remained sought after in the West. Amy Neff explains that, "Coming from the East, where Christ and his followers had lived their lives, and following age-old traditions, Byzantine icons seemed to possess unequaled authenticity." ${ }^{273}$ Decline and

${ }^{270}$ Cook, "Margarito d'Arezzo's," 84. The overpainted outlier at Ripa, rather, shows a narrow, vertically oriented open book.

${ }^{271}$ Belting, Likeness and Presence, 21.

272 Derbes, Picturing the Passion, 14.

${ }^{273}$ Neff, "Painting, Devotion, and the Franciscans," 36. 
unrest in the capital pushed artisans toward Italy and other western regions where work was plentiful and admiration for the empire's lavish style still held firm. ${ }^{274}$ The influx of icons, relics, decorated manuscripts, and luxury goods resulting from the sack of Constantinople in 1204 provided models of Byzantine art from which to work. The Franciscans' adoption of the Byzantine style was probably also related to the order's missionaries, active in the eastern Mediterranean. Francis traveled to the Levant in 1219 and preached as far as Egypt in the midst of the Fifth Crusade. ${ }^{275}$ By 1220, the friars had a congregation in Constantinople from which they developed an active trade in religious images with the West. ${ }^{276}$ Anne Derbes also describes highly decorated items such as manuscripts, textiles, and painted panels that were given as gifts to the Franciscan emissaries or that the brothers transported for delivery between dignitaries and emperors in the East and popes and kings in the West. Derbes' study of Passion imagery reveals that the implementation of eastern innovations by Italian artists was surprisingly rapid and accurate in its replication of imported icons, although few of the imported examples have survived. Thus, the eastern style was repurposed in order to lay claim to the reputation and wealth of the recently powerful imperial capital. Citing David Freedberg's The Power of Images: Studies in the History and Theory of Response (1989), Derbes

${ }^{274}$ Rice notes that France was developing its own humanistic innovations-leading to Romanesque and Gothic styles that highlighted articulation of form and dynamism. Germany, meanwhile, relied on its Ottonian heritage, yet examples such as the Gero Cross reveal a shifting sensitivity to the human form. Neither region adopted a Byzantine style of representation as the Italian artists did at this time. Rice, Byzantine Painting, 9, 73-74.

275 Armstrong and Francis, St. Francis of Assisi, 14.

276 This section draws from Derbes, Picturing the Passion, 15, 24-26, 159. The cross-cultural exchange traveled in both directions, with the friars decorating their mission churches with frescos inspired by Italian sources and sharing manuscripts of their own design. 
suggests that the spiritual and apotropaic efficacy of these icons may also have been sought in Italy. The Franciscans evidently found the wood-panel icon to be a valuable medium for creating focal points for prayer and meditation.

Throughout the Franciscans' wood and tempera examples, the depiction of Francis exhibits a remarkable consistency. This is not surprising. For iconographers, originality was not required nor desired. It was necessary to be accurate in following the artistic tradition that was passed down in order to express the spirit of the prototype, the saint him/herself. Copying transmitted the authority of the original. The depiction of new holy personages, such as the poverello, could be drawn from the pattern established for earlier saints, although additional details could elaborate on their particular religious import. ${ }^{277}$ In their chapter for the 2004 Metropolitan Museum exhibit Byzantium: Faith and Power (1261-1557), Anne Derbes and Amy Neff compare early images of Francis of Assisi to icons of John Chrysostom, the archbishop of Constantinople who was much popularized in the West (349-407) (Figure 3.4). Images of John Chrysostom display a "strongly tapered contour, narrow chin, and deeply sunken cheeks that often characterize this Church Father in Byzantine art...And the choice of John Chrysostom as a model may have been deliberate. Like Francis, he was an ascetic; his gaunt face and dematerialized body signify his rejection of worldly excess." ${ }^{278}$ Derbes and Neff understand the crosscultural sharing as evidence of the early Franciscans' agenda to reunify the Eastern and Western churches. I would add to this rationale that John Chrysostom, whose cognomen means 'golden mouth', was considered by both sides of the Schism as one of the greatest

\footnotetext{
${ }^{277}$ Ouspensky and Lossky, Meaning of Icons, 37; Derbes and Neff, "Byzantine Sphere,” 460.

${ }^{278}$ Derbes and Neff, "Byzantine Sphere,” 452-53.
} 
preachers to defend orthodox Christianity against heresy. ${ }^{279}$ By visually associating

Francis with John Chrysostom, the early Franciscans could present their founder as a saint that not only equals, but surpasses, the Cathar Perfecti who courted the laity of their day.

\section{Francis as Orthodox Preacher in Contrast to the Cathar Perfecti}

In certain ways, Francis' ideology mirrored the Cathar Perfecti. In his Second Version of His Letter to the Faithful, Francis wrote: "We must hate our bodies with their vices and sins...We must also deny ourselves and place our bodies under the yoke of servitude and holy obedience as each one has promised to the Lord." ${ }^{280}$ Yet, in their painted panels, the early brothers presented Francis as a foil to the popular Perfecti, promoting their founder as a faithful orthodox alternative. There are some who believe that Francis drew his similarities to the Cathars from familial lines. In a popular, rather than academic work (yet one held in the library of the Sacro Convento in Assisi), Gian Marco Bragadin puts forward the theory that Francis' mother Pica (Giovanna) di Bourlémont was a Cathar immigrant from Tarascon, in Languedoc. ${ }^{281}$ Whether such a close relation as this existed, or Francis simply emerged within the zeitgeist, it seems that it would have been a small step for Francis and his followers to join the Cathars' vein of ascetics. However, Francis made a conscious effort to remain within the canon of the

${ }^{279}$ Marcus Plested, "The Influence of St John Chrysostom in the West" (Symposium in Honour of the 1600th anniversary of St John Chrysostom Held Under the Aegis of the Ecumenical Patriarchate, Istanbul, Turkey, 2007), 5-6, https://www.iocs.cam.ac.uk/wpcontent/uploads/st_john_chrysostom_in_the_west.pdf.

${ }^{280}$ Francis et al., Francis and Clare, 70.

${ }^{281}$ Francis' birth name was Giovanni di Pietro di Bernardone, but he was called Francescoperhaps based on his heritage. Bragadin, S. Francesco: Le Verità, 121. 
Church. As Lambert points out, "In Francis's letter to all the faithful, he stresses the importance of confession and communion, reverence to priests and the frequent visiting of churches - all abhorrent to Cathars." 282

Returning to the iconography of the simple image of Francis, one of the most prominent and unique features is the codex that the saint holds. I contend that this element was in response to the Cathars' highly-educated Perfecti. With illustrations of over 600 panel paintings, Edward Garrison's Italian Romanesque Panel Painting: An Illustrated Index presents a useful catalog of comparanda for the Italian region and the century under consideration. This collection lists very few panels in which the subject holds a book, as the examples of this dissertation possess. The detail of Francis' book varies from the reality of the poverello himself and the earliest members of his order, for whom book ownership would have been an unnecessary luxury. Although not hostile to formal education, in general, the brothers did not own or use books until after Pope Gregory IX's papal bull Quo elongati, four years after Francis' death. ${ }^{283}$ According to Elvio Lunghi, "This custom was reported by Saint Bonaventure in his Legenda Maior, written in 1262-1263, when, in speaking of the Adoremus prayer taught by Francis to his first companions, he felt the need to explain that since the friars did not have liturgical books, they studied Christ himself...Christ's cross was their book, and they studied it day and night at the exhortation and after the example of their father who never stopped

\footnotetext{
${ }^{282}$ Lambert, The Cathars, 171.
}

283 Trinita Kennedy, Donal Cooper, Holly Flora, Amy Neff, and Janet Robson, Sanctity Pictured: The Art of the Dominican and Franciscan Orders in Renaissance Italy (Nashville: Frist Center for the Visual Arts, 2014), 4; Anscar Zawart, The History of Franciscan Preaching and of Franciscan Preachers ; (1209-1927) ; A Bio-Bibliographical Study (New York: Wagner, 1928), 260-61. 
talking to them about the cross. ${ }^{284}$ The Franciscan order's perception of reading, books, and education shifted to a more favorable place by Bonaventure's time. ${ }^{285}$ Preaching against formidable opponents required knowledge and formal training, which the Franciscans received beginning in the 1220 s. $^{286}$

In contrast, we find evidence that some Cathars were well educated—prepared for fierce debate of doctrine and especially scripture. ${ }^{287}$ The preaching of many Cathar Perfecti was highly effective, especially in the small towns of Italy, where a talented speaker could escalate the religious enthusiasm of a community to a fever pitch. ${ }^{288}$ Lansing provides contemporary accounts of numerous Orvietans converting following a well-delivered sermon. ${ }^{289}$ Cathars used the vulgate Bible daily to prepare for their preaching. ${ }^{290}$ Yvo of Narbonne, a clerk who left Italy in 1214, documents Cathars studying logic and theological oratory at the University of Paris. There is also evidence of heterodox scholastic centers in Lombardy, Tuscany, and Rome. ${ }^{291}$ In his chapter "Italian Catharism and Written Culture," Lorenzo Paolini analyzes the literary culture of the

${ }^{284}$ Lunghi, "Francis in Prayer," 349.

${ }^{285}$ Cook, "Fraternal," 269.

${ }^{286}$ Roest, Franciscan Literature, 17.

${ }^{287}$ Paolini, "Italian Catharism," 90. Paolini sees some evidence of the Cathars possessing collections of biblical passages (authorities) even before Catholics did; and maybe the increased use by Catholics of similar books were in response to this material usage.

${ }^{288}$ D'Avray, Preaching of the Friars, 26.

${ }^{289}$ Lansing, Power and Purity, 41.

${ }^{290}$ Brenon et al., "Cathars and the Representation," 253-54; Wakefield and Evans, Heresies, 5152.

${ }^{291}$ Paolini, "Italian Catharism," 96-97. 
Cathars and reconstructs what may have constituted a Cathar library. In addition to copies of the New Testament that matched the canonical text such as the Bible of Lyon, Cathar communities evidently held copies of their own contemporary treatises such as the Liber de Duobus Principiis, the Latin ritual of Florence, and Occitan ritual of Dublin. They also learned and spread the ideas, if not the actual texts, of the Church Fathers and philosophers such as Aristotle, Boethius, Tertullian, Irenaeus, Jerome, Augustine, Marius Victorinus, John Chrysostom, and William of Auvergne, as well as texts of Bogomil and Catholic rituals, glosses, and prayers. ${ }^{292}$

In contrast, the training of the secular Catholic clergy often left them woefully unprepared to instruct their parishioners. Preaching directly to the laity had been a very rare event prior to the twelfth century. The practice of giving sermons had been reserved to the monasteries, with written homilies circulated as meditative reading more often than they were meant for oral delivery. ${ }^{293}$ It became clear that an important key to defeating heresy was to incorporate direct education of their believers in the tenets of the faith and re-convert any who held errant beliefs - the most valuable tactic to increase the laity's knowledge of their faith would be through preaching. ${ }^{294}$ But the under-educated Catholic pastor often could not hold his theological ground, or his flock, in debates with the learned Perfecti. ${ }^{295}$

${ }^{292}$ Paolini, "Italian Catharism," 97-99; Wakefield and Evans, Heresies, 64; Brenon et al., "Cathars and the Representation," 253-54.

${ }^{293}$ Dansereau, Servasanto Da Faenza, 35-36.

${ }^{294}$ Wakefield and Evans, Heresies, 58.

${ }^{295}$ Paolini, "Italian Catharism,” 83. 
For the laity, and in fact even for some less-educated clergy, the beliefs held by Cathars and Catholics could be often confused and blended. Carol Lansing describes Cathars in Orvieto seeking absolution from priests in the sacrament of reconciliation, ritually adoring the Eucharist, and praying for the intercession of Catholic saints. ${ }^{296}$ In Florence, there exists testimony from 1229, in which accused heretics declared their surprise that the creed they had espoused was not "Catholic and correct."297 Wandering preachers and ascetic hermits aroused popular piety, based on the New Testament's model of the simple apostolic life in contrast to the wealth and power of the monasteries. ${ }^{298}$ While highly critical of the Cathars' teachings and motives, even the Franciscan preacher James Capelli (active c. 1240-1260) acknowledged that the heterodox believers "comport themselves very well, and they do many things which are in the nature of good works. In frequent prayers, in vigils, in moderateness of food and clothing - and that I may acknowledge the truth — in the austerity of their abstinence, they surpass all other religious." ${ }^{299}$ Lansing highlights the comparison in the town of Orvieto: "Cathar perfects, in contrast [to the Catholic clergy], were exemplars of Christian piety and poverty, uncontaminated by worldly ambition... When accused Cathars were questioned about their beliefs, the most common response was to stress the holy lives of the Perfecti. In them, and not in the Catholic clergy, lies the path to salvation." 300 To

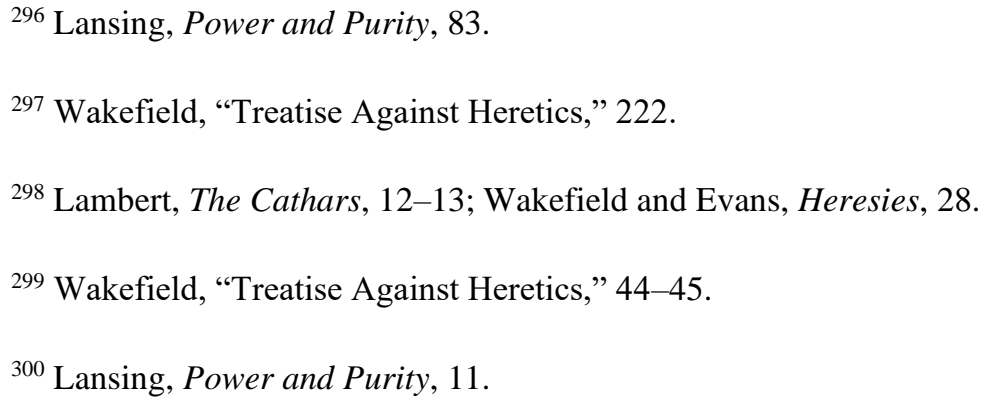


many in the laity, the Perfecti were considered to be most austere in their poverty, zealous in their celibacy, devoted to their creed even under threat of violence, and steadfast in their spiritual principles in rejection of the material world. ${ }^{301} \mathrm{In}$ order to counter the Cathars' training and rhetoric, the Church required a new strategy.

The Order of Friars Minor proved to be perfectly suited to match the Cathar preachers, equaling the Perfecti in their devotion to poverty and chastity, but also adopting the vow of obedience to the Church. Not ordained as a priest, Francis could elicit the allegiance even of those who doubted the sanctity of the clergy. Through his simplicity, people could be brought back into communion with Rome. In 1209, Pope Innocent III granted Francis and eleven of his followers permission to preach, but only on the need for repentance. Full preaching faculties were reserved to the priesthood, and as yet, none of the brothers were ordained. ${ }^{302}$ This, however, also proved to be an effective focus to counter lay interest in the Cathars, as the heretical Consolamentum ritual was a major draw, serving as a substitution for the Catholic sacrament of reconciliation. ${ }^{303}$ During this time, lay people clamored for more active participation in their faith encouraged by increased literacy and access to scripture. Especially in urban areas, revival movements and lay confraternities rose in cooperation with the Francisans' preaching efforts. These organizations gave the laity a voice and active participation in

${ }^{301}$ Wakefield and Evans, Heresies, 49-50; Brenon et al., "Cathars and the Representation,” 248.

302 Goffen, Spirituality in Conflict, 1; Roest, Franciscan Literature, 1-2. Francis was ordained a deacon, giving him limited faculties to preach. Other brothers preached under the regulation of lay exhortation. See Zawart, History of Franciscan Preaching, 262.

${ }^{303}$ Dansereau, Servasanto Da Faenza, 15. The Council of Vienne held in 1312, permitted the friars full authority to preach under Pope Clement V's bull 'Super cathedram'. See Zawart, History of Franciscan Preaching, 245. 
the life of the Catholic Church. This newfound responsibility involved training members to argue against heresy as well as promoting personal devotion to fortify orthodox beliefs. ${ }^{304}$

While the book shown in Francis' hand may have been the Gospel as proposed by Cook, it would have also called to the thirteenth-century mind the vade-mecum handbooks of contemporary Franciscan preachers. Dubbed for the Latin phrase 'go with me', these were portable preaching aids - manuscripts that developed in concert with the mendicants' itinerant ministry. They contained prepared sermon prompts, confession guides, sections of the bible, and the daily office of prayers. ${ }^{305}$ Many of these books may have also included lists of scripture composed to offer a direct dogmatic response to a specific heretical statement. ${ }^{306}$ Looking at Edward Garrison's examples, after the images of Francis included in the Index, the icon types known as Jesus the Redeemer and Redeemer Enthroned are the most often-represented figure holding a book, numbering at least eight. ${ }^{307}$ In these portraits, Jesus holds a text that is usually larger and often more richly decorated than that which Francis holds. This smaller dimension correlates with the vade-mecum books that have been estimated to measure less than 18 centimeters in height. ${ }^{308}$ The size is closer to the book held by John Chrysostom in the mosaic depiction

304 Lambert, The Cathars, 1.

${ }^{305}$ D'Avray, Preaching of the Friars, 14, 57, 61.

${ }^{306}$ Wakefield, “Treatise Against Heretics," 95-96.

${ }^{307}$ Garrison, Italian Romanesque Panel Painting, Christ 48, 50, 70, 110, 111, 113; Luke 85; James 141; Antony 151; Dominic 85, 127; bishop 107.

${ }^{308}$ D’Avray, Preaching of the Friars, 61. 
of him from Sicily created about one hundred years prior (Figure 3.4). Garrison's other examples of saints holding manuscripts include an image of Luke, James, Antony Padua, two of Dominic, and an unnamed bishop. While the small black and white reproductions of Garrison's Index make detailed study difficult, and the collection is not exhaustive, it is evident that the number of Italian panel paintings of Francis holding a small volume far exceeds that of any other book-holding saint depicted, even while taking into account the high percentage of wood panels that have been lost. Although Francis himself would not have carried a vade-mecum, he was depicted to look like the Cathar Perfecti as well as the contemporary Franciscan preachers, such as Bonaventure, James Capelli, and Servasanto da Faenza, who will be discussed in the next section. ${ }^{309}$ These images would have reinforced for the lay viewer that not only the founder Francis, but all preaching mendicants, were potential counters to the Cathar Perfecti.

Within two decades of its start, the preaching mission of the Franciscans grew, making use of the further education and subsequent ordination of many of the new friars joining the ranks. The order shifted from exhorting penance only to also preaching on doctrine and morals, basing their sermons on scripture and patristic teachings. ${ }^{310}$ In 1233 , Pope Gregory IX enacted a catechetical preaching mission with the purpose of destroying heresy, followed by Innocent IV's campaign with the same intent in 1246. The Franciscans, along with the Dominican order, were considered the most capable for this duty. Wakefield explains, "The task fell largely, though not exclusively, on the mendicant orders, a corps of devoted workers who were trained in theology and preaching and who,

\footnotetext{
${ }^{309}$ Dansereau, Servasanto Da Faenza, 28-30; Wakefield and Evans, Heresies, 301.

${ }^{310}$ Roest, Franciscan Literature, 4.
} 
in their monastic institutions and literary pursuits, had the means to accumulate and exchange with each other the literature on heresy and its refutation." 311 Dioceses relied heavily on the efforts of the friars to combat false teaching. The Council of Trier in 1227 , instructed that unschooled priests request the highly-educated friars to preach in their parishes. $^{312}$

There exists no complete text of Francis' or his earliest brothers' sermons, but accounts describe that they were given before large audiences. ${ }^{313}$ By mid-century, Bonaventure offered homilies on Francis and other early saints of the Friars Minor. Bert Roest describes the purpose of these sermons as creating "the additional possibility to highlight before a non-Franciscan public various specifically Franciscan virtues (poverty, humility, love for the suffering Christ) within an overarching programme of religious instruction." 314 These thirteenth-century texts probably served as models for countless vernacular sermons offered throughout Europe. ${ }^{315}$ The friars preached to crowds that possessed varying degrees of secular and religious education-merchants and lawyers, farmers and peddlers, beggars, knights, and nobility. ${ }^{316}$ Men and women of all ages,

${ }^{311}$ Wakefield, “Treatise Against Heretics," 216-17.

312 Roest, Franciscan Literature, 3.For a broad discussion of mendicants preaching with artwork inside churches, see Cooper, "Preaching amidst Pictures."

${ }^{313}$ Moorman, History of the Franciscan Order, 274; Brooke, Image of St Francis, 95.

${ }^{314}$ Roest, Franciscan Literature, 20.

315 The extant collection of Bonaventure's homilies number at least 380 sermons. Cook, "Fraternal," 265; Jay M Hammond, J. A. Wayne Hellmann, and Jared Goff, A Companion to Bonaventure (Leiden: Brill, 2014), 403-4.

${ }^{316}$ D’Avray, Preaching of the Friars, 6, 10, 35, 63. 
political agendas, and variety of belief came to listen to the preachers. ${ }^{317}$ Increased preaching to the laity led also to changes in the delivery of sermons, which became "brief, pointed, and presented with a flourish." ${ }^{318}$ Audiences voted with their feet. Effective preachers incorporated jokes, traditional and popular stories and tunes, and dramatic special effects. ${ }^{319}$

It is my contention that the early Franciscans may also have used the panel paintings as visual aids to engage the audience and focus their attention. Utilizing artwork for promotional and catechetical purposes was a common tactic for the early Franciscans. A number of scholars have examined extant and historical imagery found within churches, such as Donal Cooper, Janet Robson, Holly Flora, and Rosalind Brooke. However, regarding the usage of the wood-panel images of Francis in response to the Cathars, it is necessary that we look beyond church walls. Heretics were not usually found in Catholic sanctuaries, and the Franciscans did not want to limit their message to only the faithful. By providing portable images of their founder as publicly accessible liturgical art, the preachers better ensured that both the faithful and unbelievers would have had opportunity to view it.

Other than at the basilica in Assisi, in the earliest decades of the Order of Friars Minor, the brothers did not build large church structures. Instead, during the midthirteenth century, mendicant friars regularly preached in the town squares and in

317 Augustine Thompson, Revival Preachers and Politics in Thirteenth-Century Italy: The Great Devotion of 1233 (Eugene, Oregon: Wipf and Stock, 2010) 98.

${ }^{318}$ Mark Zier, quoted in Dansereau, Servasanto Da Faenza, 37.

${ }^{319}$ Roest, Franciscan Literature, 17. 
marketplaces, in open fields and cemeteries, and during feast day processions. ${ }^{320}$

Although the friars established permanent residences in hermitages and convents, such as the hermitage at Monteluco discussed in Chapter 2, they continued to travel widely for their apostolic work, using their permanent settlements in towns and rural areas as hostels. ${ }^{321}$

The best sources of information on the early Franciscans' outdoor preaching are the accounts of the Great Alleluia of 1233. In her book Preaching Peace in Renaissance Italy: Bernardino of Siena \& His Audience, Cynthia Polecritti describes this ten-month long campaign as a charismatic movement to initiate personal and public reconciliations, enact laws for societal change, and espouse doctrine against heterodoxy. ${ }^{322}$ She enumerates the practical and material considerations to create a successful experience for both the preacher and the audience:

Before the sermon began, some groundwork was necessary. A preacher's impact depended on his audibility and visibility. Since most sermons of the Alleluia took place outside the cities, in fields or on banks of rivers, a stage of some type was essential. During the great assembly at Paquara, John of Vicenza employed a kind of look-out tower (specula) of wood... On another occasion, John made do with preaching from the carroccio of Verona... Such devices not only raised the friar high enough to be seen, they allowed him to throw his voice over the heads of the crowd... Although it is never directly mentioned, these preparations would have required a 'road crew' of considerable size. ${ }^{323}$

${ }^{320}$ The Council of Angers forbade outdoor preaching in 1448. Goffen, Spirituality in Conflict, 2; Beverly Mayne Kienzle, "Medieval Sermons and Their Performance: Theory and Record," in Preacher, Sermon and Audience in the Middle Ages, ed. Carolyn Muessig (Leiden: Brill, 2002), 91-92; Cooper, "Preaching Amidst Pictures," 34.

${ }^{321}$ Zawart, History of Franciscan Preaching, 243, 261; D’Avray, Preaching of the Friars, $39,52$.

${ }^{322}$ Cynthia L Polecritti, Preaching Peace in Renaissance Italy: Bernardino of Siena \& His Audience (Washington, D.C.: Catholic University of America Press, 2000), 93.

323 Thompson, Revival Preachers, 92-93. 
While it is widely held that the friars employed movable artwork, textual documentation that these panels were carried is meager. ${ }^{324}$ The simple icons are the size of modern marquee posters and may be compared also to this same function-advertising the topic of an upcoming sermon or illustrating the preacher's narrative. While two of the vita dossals, at Santa Croce and Siena, are quite large standing at approximately $230 \mathrm{~cm}$ tall, the other icons and dossals in this study could have been even more manageable as mobile images with their longer dimensions ranging between 86 and $180 \mathrm{~cm}$. A good example is the simple icon held in Castiglion Fiorentino, a town which has a strong local tradition of carrying artwork in religious processions passed down to the current day, even conveying a monumental crucifix panel painting. The director of the museum, Dr. Pierpaolo Mangani removed the icon of Francis from its display and allowed me to hold it. Estimating its weight to approximately 6 kilos, I would suggest that one person could carry it comfortably over a considerable distance (Figure 2.8).${ }^{325}$ David Bomford in his discussion of the conservation of panel paintings for the Getty Museum, describes wood as "an ideal material for movable paintings and altarpieces. It is strong, relatively light, and self-supporting." 326 The same "road crew" that built a preacher's platform could

${ }^{324}$ The troublingly ephemeral nature of both the preacher's words and interactions with the audience is discussed in C.A. Muessig, Preacher, Sermon, and Audience in the Middle Ages (Leiden, Netherlands: Brill, 2002), 5; Franco indicates the use of mobile panels, but does not specify occurrences. Franco, "The Functions of Franciscan Art," 21, 44.

${ }^{325}$ Conversation with Dr. Pierpaolo Mangani, manager of the Pinacoteca Comunale, Castiglion Fiorentino, June 12, 2019; It is recorded that a dossal from Pisa was carried through the streets in procession in 1631, but whether or not this practice occurred as early as the thirteenth century is not known. See Gregory W. Ahlquist and William Cook, "The Representation of the Posthumous Miracles of St Francis of Assisi in Thirteenth-Century Italian Painting," Art of the Franciscan Order in Italy / Ed. by William R. Cook., 2005, 216.

326 David Bomford, "Introduction: Keynote Address," in The Structural Conservation of Panel Paintings: Proceedings of a Symposium at the J. Paul Getty Museum, 24-28 April 1995., by Kathleen Dardes and Andrea Rothe (Los Angeles: Getty Conservation Institute, 2013), xv. 
easily have carried even the largest wooden panels to the site along with other construction supplies. The ability to transport these works to outdoor public areas for the friars' preaching would have opened up an entirely new audience for their catechesis-a more diverse population than that which would have attended a Catholic Mass.

Bonaventure supported using artwork to enhance understanding of the words of the preacher. He explains that images are valuable to educate the illiterate, to motivate flagging attention which is encouraged better by seeing than hearing, and to assist recollection. ${ }^{327}$ In 1253, when two Franciscan friars, William of Rubruck and Bartholomew of Cremona, were sent on a mission trip to the court in Karkorum, Mongolia, it is recorded that the brothers took along images with which to aid their efforts at conversion. In this case, they carried a bible, a breviary, and an illuminated psalter. Evidently the illustrations intrigued the khan Mönke, who questioned the friars about the meanings behind each image. Another example is the missionary friar Giovanni da Montecorvino (1247-1328) who wrote from Beijing that he had commissioned six images depicting Old and New Testament scenes for the work of his mission, using the pictures to educate the community. He had inscriptions in several languages applied so that they would have a broader reach. ${ }^{328}$ If friars traveling great distances incorporated images into their preaching to non-believers, it is reasonable to argue that local preachers would do the same in the attempt to convert Cathars, and be less fettered by the size of the images available to them.

\footnotetext{
${ }^{327}$ Jay M Hammond, "Preaching by Image: The Counter Façade of the Basilica of St. Francis," in Franciscans and Preaching / Ed. by Timothy J. Johnson., 2012, 414.

${ }^{328}$ Derbes and Neff, "Byzantine Sphere,” 451-52.
} 
In my search for material clues of the panels having been transported for outdoor preaching or simply from town to town, I found that the backs of several panels were marred with nail holes that would have been at the appropriate placement for a brace to be positioned across the back of the panel. These braces would have been in addition to the horizontal battens of an icon. They could have facilitated rings, hooks, poles, or other mechanisms for carrying the piece.

Visual evidence of artwork brought to an outdoor venue can be found in the vita dossal of Pistoia (Figure 3.5). In this panel, possibly the oldest image of Francis preaching to a crowd, he stands on a raised platform accompanied by two brothers. The sides of the podium are angled, perhaps indicating steps, while the structure rests on thin columns. A crowd stands below on either side, seeming to listen intently as Francis raises his right hand. With his left hand, he gestures toward the decoration on the platformmonochromatic green images of two birds within scalloped roundels. While these images appear to be decorative textiles rather than panel paintings, it is clearly purposeful artwork. The representation on the cloth calls to mind Francis' sermon to the birds, which will be discussed in Chapter 4 .

A more explicit, although later example, can be seen in images of the Franciscan Bernardino da Siena, who preached in Florence 1424-1425 and Siena in 1425 and 1427 (Figure 3.6). Accounts of his homilies tell of Bernardino catechizing through the incorporation of artworks from the cathedral, the Palazzo Publico, the Piazza del Campo, and other public settings; including explanations of artworks by Ambrogio Lorenzetti and 
Simone Martini. ${ }^{329}$ His finale at each sermon was the revealing of the Christogram YHS, displayed in golden letters on a blue field, which moved the crowd to a charismatic frenzy. ${ }^{330}$ Although Bernardino has been regarded as an innovator in the use of religious art, I contend that his fifteenth-century ministry followed a strong and well-established tradition of Franciscans illustrating their itinerant preaching through portable imagery.

\section{Francis as Alter Christus Manifested in the Stigmata}

Turning now to the final, and arguably the most important, element of these early icons, we will look at depictions of Francis' mystical and physical wounds. The Order of Friars Minor set their founder as a foil to the Cathar Perfecti. To do so, the early brotherhood promoted the image of Francis as a parallel to the Cathar tenet of spiritual and physical poverty, but their artwork made it clear that Francis' stigmata surpassed anything that the heresy had to offer the people. The driving force behind the early artistic representations of Francis was the desire to display the saint as the perfect imitator of Christ. ${ }^{331}$ In his thesis, the Franciscan scholar Thomas Herbst explains the poverello's understanding of Jesus that led to this relationship:

Francis was born into the spiritual milieu of the twelfth century. As such, his Christology was colored by the historical consciousness of the time, which tended toward scriptural literalism, and affectivity. Throughout his life he strove to imitate Christ in a literal fashion according to his own understanding of Christ's life as one long Passion. The affective nature of

\footnotetext{
${ }^{329}$ Nirit Ben-Aryeh Debby, “The Preacher as Goldsmith: The Italian Preacher's Use of the Visual Arts.," Preacher, Sermon and Audience in the Middle Ages / Ed. by Carolyn Muessig., 2002, 130, 139.

${ }^{330}$ Polecritti, Preaching Peace, 72.

${ }^{331}$ For a discussion of both miraculous and scientific interpretations of stigmatization, see Carolyn Muessig, The Stigmata in Medieval and Early Modern Europe (Oxford: Oxford University Press, 2020), 63.
} 
his Christology led him to a highly emotional and intimately personal, union with the object of his devotion: Christ Crucified. ${ }^{332}$

Francis had a devotion to Jesus' Passion that permeated his daily prayer and emphasized his own determination to imitate Christ. Seven times each day, he prayed from what became known as the Office of the Passion. This meditation, developed by Francis, was based on psalms and scriptures that focused on the suffering, death, and resurrection of Jesus. In his prayers, Francis identified with Jesus, addressing God as "my most holy Father" in a more personalized and intimate manner than the original passages on which Francis' verses were based. ${ }^{333}$

Francis' miraculous stigmatization was considered to be prime evidence that the saint shared a typological connection with the crucified Christ. ${ }^{334}$ Describing this phenomenon, which occurred in September 1224, outside the La Verna hermitage north of Arezzo, Thomas of Celano wrote:

...he saw in the vision of God a man, having six wings like a Seraph, standing over him, arms extended and feet joined, affixed to a cross. Two of his wings were raised up, two were stretched out over his head as if for flight, and two covered his whole body. When the blessed servant of the most High saw these things, he was filled with the greatest awe, but could not decide what this vision meant for him... While he was unable to perceive anything clearly understandable from the vision, its newness very much pressed upon his heart. Signs of the nails began to appear on his hands and feet, just as he had seen them a little while earlier on the crucified man hovering over him. His hands and feet seemed to be pierced through the middle by nails, with the heads of the nails appearing on the inner part of his hands and on the upper part of his feet, and their points protruding on opposite sides. Those marks on the inside of his hands were round, but rather oblong on the outside; and small pieces of flesh were visible like the points of nails, bent over and flattened, extending beyond

${ }^{332}$ Thomas Herbst, OFM, "Humanization of Christ," 19-20.

333 Armstrong and Francis, St. Francis of Assisi, 177, 180.

${ }^{334}$ Kennedy et al., Sanctity Pictured, 21. 
the flesh around them. On his feet, the marks of nails were stamped in the same way and raised above the surrounding flesh. His right side was marked with an oblong scar, as if pierced with a lance, and this often dripped blood, so that his tunic and undergarments were frequently stained with his holy blood. (I Celano, Book 2, Chapter III) ${ }^{335}$

Bonaventure explained the encounter in his 1261 Legenda Maior, as follows:

On a certain morning about the feast of the Exaltation of the Cross, while Francis was praying on the mountainside, he saw a Seraph with six fiery and shining wings descend from the height of heaven. And when in swift flight the Seraph had reached a spot in the air near the man of God, there appeared between the wings the figure of a man crucified, with his hands and feet extended in the form of a cross and fastened to a cross...the fact that he was fastened to a cross pierced his soul with a sword of compassionate sorrow... [Francis] came down from the mountain, bearing with him the image of the Crucified, which was depicted not on tablets of stone or on panels of wood by the hands of a craftsman, but engraved in the members of his body by the finger of the living God. (Legenda Maior, Chapter XIII) $)^{336}$

Bonaventure understood the marking of Francis with the sign of the cross as a herald to Francis' eventual transformation into the total likeness of the crucified Christ which would occur upon Francis' death. ${ }^{337}$ As noted earlier, in the icons of the poverello, the viewer is afforded a view of Francis' feet from the top surface, emphasizing the placement of the two nails. In similar full-length icons of other saints from this period, the feet are rarely positioned in such an oblique angle. Francis' feet rather mirror the vertical pose of Jesus' feet during the Crucifixion.

\footnotetext{
335 Thomas et al., Francis Trilogy, 103-4.

${ }^{336}$ Bonaventure and Cousins, Bonaventure: Soul's Journey, 305-307.

337 Bonaventure and Cousins, Bonaventure: Soul's Journey, 305-306.
} 
According to William Cook, thirteenth-century artists depicted the stigmatization at La Verna more than any other event from Francis' biography. ${ }^{338}$ Of the paintings considered for this dissertation, the scene is incorporated into the small narrative scenes of the Pescia, Florence, Pistoia, Orte, and Siena dossals (See Figures 3.7-3.11). The dossals of Pisa, Rome, and Assisi omit it, focusing instead on healing miracles. All the illustrations place this event in a mountainous landscape with Francis kneeling as he looks up toward the seraph in the sky above. Each panel includes architectural structures thought to be chapels, except Orte which shows only a cave and an altar within. Pistoia and Siena also include a cave though less prominently. The seraph varies in slight but important details. All possess six colorful wings covering the torso. In the Bardi Dossal, the wings appear to cover the celestial being entirely, but damage to the panel makes this uncertain. Only in the Orte dossal is the seraph plainly attached to a cross, as described by Thomas of Celano in his first vita. The Florentine, Sienese, and Ortean dossals include the additional detail of three golden lines connecting the celestial being to Francis. These rays are depicted with very fine, almost imperceptible, gilded lines in Orte, though wider in the Bardi panel. In Siena the engraved lines are scarcely implied, descending from the feet of the seraph. In Pescia, the saint's connection to the seraph is represented by a broad golden band. ${ }^{339}$ Based on Thomas of Celano's text, the seraph represents Jesus-

\footnotetext{
${ }^{338}$ Cook counts 22 examples of the subject from the thirteenth and early fourteenth centuries. Cook, "Fraternal," 274.

${ }^{339}$ Cook notes that the number of rays may relay Trinitarian symbolism. While Francis' relationship to the Jesus is well documented, additional research is needed to analyze the theological significance of the artwork connecting Francis to the Father and Holy Ghost, the other Persons of the Trinity through these three rays. William Cook rejects that Orte possesses rays, yet he perceives an array of lines in the Pistoia dossals, whereas I did not observe any. This may be due to paint loss in the area. Cook, "Orte Dossal," 42; Cook, "Dossal in Siena," 13.
} 
described as a "crucified man hovering over him nailed to the cross." 340 The golden lines create a visible connection between the two figures, underscoring that Francis was attached to the crucified Christ

Following his experience, Francis was physically impaired by the wounds of the stigmata for the final two years of his life. ${ }^{341}$ Bonaventure recounts, "Since he could not walk because of the nails protruding from his feet, he had his half-dead body carried through the towns and villages to arouse others to carry the cross of Christ." (Legenda Maior, Chapter XIV) $)^{342}$ After the death of Francis, Elias of Cortona (c. 1180-1253), one of the earliest followers of Francis and second Minister General, revealed the marks on Francis' body to those gathered at his deathbed. ${ }^{343}$ Thomas of Celano describes the mixed emotions of the brothers during this difficult time:

Then incredible joy lightened their grief! A new miracle turned their minds to amazement...It seemed he had just been taken down from the cross, his hands and feet pierced by nails and his side wounded by a lance... It was even more wonderful for them to see in the middle of his hands and feet not just the holes of the nails, but the nails themselves formed by his own flesh, retaining the dark color of iron, and his right side red with blood. (I Celano, Book 2, Chapter IX) $)^{344}$

\footnotetext{
340 Thomas et al., Francis Trilogy, 103-4.

${ }^{341}$ Bonaventure, The Life of St. Francis, trans. E. Gurney Salter (Charles River Editors, 2013),
} $377-81$.

342 Bonaventure and Cousins, Bonaventure: Soul's Journey, 315.

343 Derbes, Picturing the Passion in Late Medieval Italy, 18.

344 Thomas et al., Francis Trilogy, 120. 
Elias announced the miracle of the wounds and their significance in a letter dated October 1226. ${ }^{345}$ Numerous brothers as well as people from outside the order attended Francis' deathbed, giving credence to the nature of his wounds. ${ }^{346}$ Although Pope Gregory IX did not mention the stigmata in Mira circa nos, his bull of canonization in 1228, nine years later, he supported the spread of iconography that incorporated the stigmata on Francis' hands and feet. Elviro Lunghi asserts that this endorsement was aimed at quelling the refutation of the stigmata by secular clergy. ${ }^{347}$ The text of Gregory's later papal bull, Usque ad termini, promulgated in March of 1237, is reflected in the inscription of the icon by the Master of St. Francis held in the Porziuncola (Figure 3.12). ${ }^{348}$

The pages Francis holds proclaim:

I chose him while I lived and as I died (Hic michi viventi lectus fuit et morienti)

while the text flanking Francis' lower legs reads:

Jesus' stigmata adorn me, and my stigmata expressly prove me his delight. Let no one impugn this my privilege, but give glory to Christ whom it pleased to exalt me with such worthy signs" (Me Jesus expresse / Dilectum me comprobat esse / Cuius sic me stigmata / Stigmata meque decorant); Nemo causetur / Sed Christo glorificetur / Cui placuit dignis / Me sic attollere signis). ${ }^{349}$

345 Derbes, Picturing the Passion in Late Medieval Italy, 18.

${ }^{346}$ For a list of witnesses to Francis' wounds seen during his life and following his death, see Bonaventure, Life of St. Francis, 377-81; Brooke, Image of St Francis, 167.

${ }^{347}$ Lunghi, "Francis in Prayer," 344.

${ }^{348}$ Brooke, Image of St Francis, 299.

${ }^{349}$ Paleography and translation from Goffen, Spirituality in Conflict, 15. 
This painting was probably created during a resurgence of doubt in Francis' wounds in the 1250s, which was again countered by papal support of the stigmata-this time by Pope Alexander IV (r. 1254-1261), another Cardinal Protector of the order. ${ }^{350}$ Both the writings and the icon present Francis as a worthy mirror of Jesus, chosen by Christ himself to imitate him perfectly in the flesh. ${ }^{351}$ This image may have been the first time the side wound was visualized through an opening in Francis' tunic. In the 1230s and 1240s, displaying the side wound was avoided potentially because the miracle was so unique as to be divisive. The Louvre dates its painting of Francis to 1235-1240 (Figure 3.13), making it possibly the oldest icon we consider (matching or close to Berlinghieri's 1235 dossal in Pescia). But Cook casts doubt on such an early creation. ${ }^{352}$ He says that "if it indeed originated in the $1230 \mathrm{~s}$, it is an isolated example of the representation of the side wound in Italy before the 1250s." ${ }^{353}$ The wounds displayed in the Louvre panel are larger than others and painted a garish red. In contrast, on the panels associated with Margarito d'Arezzo and the Master of St. Francis, the stigmata was painted as small, dark circles - some seemingly overpainted with red, but usually done in black. The Cimabue icon, as our latest example (1280s or 1290s), displays reddish wounds with no hint of black on the extremities and a gash in Francis' torso revealed convincingly through an unraveling hole in the fabric of his tunic (Figure 3.14). Still, only four isolated figures of

${ }^{350}$ Cook, “Margarito d'Arezzo’s,” 84.

${ }^{351}$ Ideas for this section were formulated while in conversation with Fr. Wayne Hellman, OFM Conv., September 26, 2019.

352 Cook, “Margarito d'Arezzo’s,” 84, 88.

${ }^{353}$ Cook, “Margarito d'Arezzo’s, 88. 
Francis in this study bear the side wound in their original form: the Louvre's version, the image originally from Sargiano in Arezzo, and the icons by the St. Francis Master and Cimabue in the Porziuncola. ${ }^{354}$ None of the central figures of Francis in the vita dossals display the side wound, several despite their later date from the second half of the thirteenth century. This was unusual as the depiction of the side wound was in common usage by $1260 .{ }^{355}$ Cook explains that, in addition to the difficulty of presenting a wound in a location normally hidden by clothing, "some people must have been appalled or scandalized at the implication that could be drawn that Francis was just like Christ and that he was greater than any other saint." 356 Despite the side wound's absence in some images, the detail of the stigmata itself, the additional handheld cross, as well as the cross decoration on the book carried by Francis in several of the icons, all reiterate the message of the stigmata: Francis has taken up his cross and was worthy to receive the same wounds as Jesus. ${ }^{357}$

Trinita Kennedy contends that the manner in which Francis was understood by the order and his depiction evolved in the first century after Francis' death. Memories of the man were replaced by images of the saint as alter Christus. ${ }^{358}$ This typological

${ }^{354}$ According to the Vatican Pinacoteca's conservation report of the 1965 restoration by Gianluigi Colalucci, the side wound shown in the icon of the Vatican Pinacoteca was a later addition.

${ }^{355}$ Cook, "Dossal in Siena," 7.

356 Cook, "Margarito d'Arezzo’s,” 84.

357 Although the date of 1265-1275 is given by the Museo del Tesoro della Basilica di San Francesco for the dossal San Francesco e quattro miracoli, Cook asserts that it was instead completed in time for the dedication of the Upper Basilica in 1253, which would have made these panels from Assisi the first to use the imagery of the handheld cross. Cook, 86-87.

358 Kennedy et al., Sanctity Pictured, 19. 
relationship set Francis apart from both the Cathar Perfecti and all previous saints. Rona Goffen describes the early panels of the poverello as "indistinguishable from the depictions of other saints in contemporary art." 359 The profound difference was the stigmata. These wounds of Jesus, mirrored in Francis' flesh, elevated the saint to a higher priority in the chain of intercessory power. The prayer with which Thomas of Celano closes his second book reveals the confidence the friars attached to the stigmata and promoted to their audience:

O father [Francis], place before Jesus Christ, son of the Most High Father, His sacred stigmata; and show Him the signs of the cross in your hands, feet, and side, that He may mercifully bare His own wounds to the Father, and because of this the Father will ever show us in our anguish His tenderness. (I Celano, Book 2, Chapter X) $)^{360}$

Likewise, Bonaventure actively promoted Francis as a second Christ, stressing his humility, life of renunciation, and embrace of poverty. Images were produced to more profoundly reflect the similarity between the saint and Jesus starting in the mid-century and increasing during the time Bonaventure served as minister general to the order. ${ }^{361}$ In his Legenda Minor, Bonaventure hails Francis as "the outstanding follower of Jesus Crucified." 362 Bonaventure says, "In all things he wished to be conformed to Christ crucified, who hung on the cross poor, suffering and naked...for he strove to conform

${ }^{359}$ Goffen, Spirituality in Conflict, 16.

${ }^{360}$ Thomas et al., Francis Trilogy, 127; Goffen, Spirituality in Conflict, 16.

${ }^{361}$ Derbes, Picturing the Passion in Late Medieval Italy, 21-22.

${ }^{362}$ Bonaventure and Cousins, Bonaventure: Soul's Journey, xiv-xv. 
himself to Christ and to imitate him perfectly. ${ }^{" 363}$ The stigmata, more than any other sign, encouraged both doubters and believers to turn to Francis as the alter Christus.

363 Legenda Maior, Chapter XIV, Bonaventure and Cousins, Bonaventure: Soul's Journey, 318. 


\section{Chapter 4. Vita Dossals as a Response to the Cathar Heresy}

Elaborating on the simple image of the poverello, the Order of Friars Minor simultaneously commissioned vita dossals to celebrate their founder. In total, the vita dossals include sixty-six small narrative scenes. Throughout the painted dossals, many illustrations are duplicated, while some contain unique events that were never repeated. ${ }^{364}$ The choice of subjects often reflects the concerns of local friars and their congregations at specific points in time, revealing a high level of autonomy. ${ }^{365}$ I will limit my argument to the representations that would have most directly countered the beliefs of the Cathar heretics. After considering the solitary dossal that presents heretics explicitly, I will address how the artworks' recurring themes of physical healing, the Incarnation and Real Presence of the Eucharist, and the intrinsic goodness of the natural world augmented the mission of the friars.

The compound format of the vita dossal had been used for devotional objects for numerous historical saints in both the East and West. ${ }^{366}$ Francis, however, was a man who had lived within the lifetime of the patrons, artists, and audience-familiar but also other-raised beyond human and holy as the alter Christus. ${ }^{367}$ These panels served the Franciscans in a variety of ways, such as teaching the story of Francis' extraordinary life and relationship to Jesus, defending the brotherhood's mission, lifestyle, and role in the

${ }^{364}$ Franco, "Functions of Franciscan Art," 35.

365 Great variety is evident in Franciscan art until 1292, when the iconography of Francis' life and miracles was concretized by the completion of the twenty-eight frescoes in Assisi's Upper Basilica. Cook, "Fraternal," 266; Franco, "Functions of Franciscan Art," 39, 43.

${ }^{366}$ Brooke, Image of St Francis, 168-69.

${ }^{367}$ Franco, "Functions of Franciscan Art," 20, 42. 
Church; inspiring discipleship and piety, and promoting the pilgrimage site recently established in Assisi. As discussed in the last chapter, I contend that these depictions of Francis' life were employed to illustrate the friars' sermons preached outdoors, thereby reaching a more diverse audience than would have been found inside a church. In this chapter, we will continue to explore how these panels also served as a subtle yet potent instrument to combat the Cathars - validating the doctrines of the Church in the face of heterodoxy.

This dissertation considers the eight extant thirteenth-century wood-panel vita dossals of Francis (See Catalog 2 for data regarding these dossals). Two of the woodpanels, in Assisi and the Vatican, have horizontal orientations, while the other six stand vertically. The latter are topped with triangular gables, known as cuspidate. They are each comprised of full-length representations of the saint, following the iconography of the simple icons discussed in the last chapter. They contain four to twenty narrative scenes of varying scale, grouped on either side of the central standing figure. In Assisi and the Vatican, two scenes on each side measure to approximately half the height of Francis' portrait. The Orte Dossal also has four scenes, but at a considerably smaller scale of about one sixth the total height of the panel. The dossals in Pescia, Pisa, Pistoia, and Siena line their vertical sides with three to four scenes each. The outlier is the Bardi Dossal of the Basilica of Santa Croce in Florence. This artwork contains twenty additional scenes on both the sides and base, surpassing all other comparanda in its complexity.

The rationale for the order and placement of the various narrative scenes among the dossals is a complex question. Generally, the dossals can be read in a linear fashion. 
Most possess a chronological sequence with episodes that occurred earlier in Francis' life placed closer to the left side. For example, the Bardi Dossal is read starting at the upper left. It zigzags from top to bottom before concluding at the upper right. In Siena, the viewer's eye moves clockwise starting in the lower left. William Cook also points to thematic arrangements of the scenes. For example, stories in which the saint preaches are grouped together on the left side of the Bardi Dossal, while miracles accomplished during his life and posthumously form the column of scenes on the right. Thematically, in Siena, Francis' conversion is illustrated by his rejection of material wealth in front of Bishop Guido at the lower left corner. The bishop returns in the parallel scene at the righthand side, depicting Francis' funeral. Both stories signify a spiritual rebirth, according to Cook. Likewise, Francis' prayer before the Cross of San Damiano is paired laterally with the nativity at Greccio - both mystical encounters in which Jesus was perceived through the physical senses. Cook also encourages noting small details: where does Francis bear the stigmata, in which scenes does he wear the habit or tonsured hair, for example? For the attentive viewer, particularly one familiar with Francis' vitae, both the broad and fine elements offer much to contemplate. ${ }^{368}$

Reflecting the subtlety by which the order addressed heresy, in the early biographies of Francis, there is only one direct reference to the Cathars. And only one dossal portrays this singular encounter. In his second version of the life of the saint,

${ }^{368}$ Schematic analysis such as this is explored throughout Cook's texts, particularly in Cook, "Dossal in Siena," 16-17; Cook, "New Sources," 330, 333; Cook, "Orte Dossal"; Rosalind Brooke also compares the placement of scenes between the Bardi, Pistoia, and Pescia panels. See Brooke, Image of St Francis, 181-86. 
Thomas of Celano relays an attempt of the heretics to discredit Francis. ${ }^{369}$ The Cathars wanted to spread the rumor that Francis was not as flawless as the highest order of Cathars, the Perfecti, because Francis consumed meat. Francis justified this behavior in his Rule by turning to scripture: Jesus said, “And into what city soever you enter, and they receive you, eat such things as are set before you." (Luke 10:8) ${ }^{370}$ When Francis was invited to a dinner in Alessandria, in Lombardy, he was served poultry, which he shared with a seemingly poor beggar who came to the door. The following day, as Francis was preaching to a crowd, the supposed beggar, whom Celano called a "son of Belial," publicly showed his evidence that Francis consumed meat. ${ }^{371}$ Celano tells us that the capon the Cathar displayed miraculously turned into fish which was considered acceptable by the vegetarian Cathars. The crowd turned on the Cathar, who asked for Francis' forgiveness. ${ }^{372}$ According to William Cook, the Orte dossal contains the only extant representation of this story of the Cathars' reconciliation from this period, shown in the lower left-hand corner (Figure 4.1). ${ }^{373}$

The dossal of Orte was created for one of the early churches of San Francesco built or used by the Friars Minor in the town (Figure 4.2). The wood panel was later transferred to the cathedral, and it now stands in the Museo d'Arte Sacra di Orte, in the

${ }^{369}$ II Celano, Book 2, Chapter XLVIII, Thomas et al., Francis Trilogy, 216-17.

${ }^{370}$ Zuppante, “L’Eresia Nella Tuscia,” Par. 10.

${ }^{371}$ This was a common epithet for Cathars in the region. Cook, "Orte Dossal," 44.

${ }^{372}$ Fish was believed to reproduce without coitus, making it licit to consume. Lambert, The Cathars, 173.

${ }^{373}$ Cook, "Orte Dossal," 44; Franco, "Functions of Franciscan Art," 38. 
deconsecrated church of San Silvestro. ${ }^{374}$ The painting is attributed to the same artist as the Master of the Dossal of Saint John the Baptist of the Pinacoteca Nazionale di Siena, an anonymous painter of Umbrian-Sienese influence. ${ }^{375}$ The Orte Dossal is also unique in that it is the only example that seems unfinished. Framed by slender columns, gilded vertical blank spaces fill the areas between the upper and lower scenes giving the impression that the artist's plan changed mid-course. Francis stands at the center, surrounded by corner blocks that illustrate the stigmatization, the sermon to the birds, the conversion of the Cathar, and what appears to be a posthumous miracle of a reconciliation event that incorporates a painted icon of Francis (Figure 4.3). There does not appear to be a textual source for this final scene painted in the lower right corner. Although rare to not have a referent in Celano's or Bonaventure's writing, it is not without precedent. Cook argues for other examples, particularly in the Bardi Dossal, in which narrative scenes may have been based on local oral tradition rather than literary sources. ${ }^{376}$ While Bradley Franco considers this last scene more generally about civil arbitration accomplished by the friars, William Cook theorizes that this section may relate to a specific occurrence of heresy that occurred within the region. This seems a reasonable answer to the puzzling iconography, and Abbondio Zuppante, the curator of

\footnotetext{
${ }^{374}$ Zuppante, “L’Eresia Nella Tuscia,” Par. 1.

${ }^{375}$ Zuppante, “L’Eresia Nella Tuscia,” Par. 2.

${ }^{376}$ See Cook, "New Sources."
} 
the Museo d'Arte Sacra, provides convincing evidence for particular citizens on whom the scene may be based, gleaned from the town's archive. ${ }^{377}$

Both the Franciscan order and the Cathars were deeply entrenched in the city of Orte by the time of the dossal's creation, which Cook dates to $1260 .{ }^{378}$ The town was one of the first stops Francis and his early brothers made in 1209 along their route home from Rome, where Pope Innocent III had approved their rule. Two additional visits to the town are recorded, during which Francis healed the physical deformities of a youth and an adult. ${ }^{379}$ The friars established a community there no later than 1236 , but they appear to have moved locations a number of times before 1259 , when they were given the church of Sant' Angelo within the city. ${ }^{380}$

Likewise, Cathars could be found in the region dating at least from 1235, attested by Pope Gregory IX's directions to the bishop of Orte to rout out local heretics. ${ }^{381}$ Several names of known or suspected heretics are mentioned in the town's records, including the families of Capello of Chia, Raynerius de Percano, Giovanni da Orte, and Mattafellone di Cacciaguerra, who fell under inquisitional scrutiny between 1255 and 1260 , the years leading up to the creation of the dossal. The friars named in the prosecution are Pietro da Firenze, Andrea da Todi, Gentile da Bettona, and Bartolomeo

377 Zuppante, “L'Eresia Nella Tuscia,” Par. 35, 38-40; Cook, “Orte Dossal,” 44-45; Franco, "Functions of Franciscan Art," 37.

${ }^{378}$ Cook, "Orte Dossal," 41.

${ }^{379}$ Zuppante, “L’Eresia Nella Tuscia,” Par. 43.

380 Zuppante, “L'Eresia Nella Tuscia,” Par. 49-50; Cook, “Orte Dossal,” 41.

${ }^{381}$ Cook, “Orte Dossal," 44. 
da Amelia. ${ }^{382}$ The religious order's choice to depict heretics, specifically Cathars, being reconciled to the Church by Francis would have resonated quite strongly with the inhabitants of Orte. According to Zuppante, rather than focusing on the condemnation and suppression inherent in the inquisition, both lower scenes turn the viewers' attention instead to communal celebration at the recovery of a lost soul. ${ }^{383}$

If we accept that the fourth scene, showing a crowd divided under a painting of Francis, does in fact represent local Cathars brought back into the Church, it is imperative to note that the agent of this reconciliation is not the person of Francis or the friar inquisitors. Rather the conversion is actuated by a dipintura icon of the saint. This icon represents Francis half-length beneath a gable. The iconography of the book and the blessing gesture matches the portable icons discussed in Chapter 3, which I theorize the brothers would have carried and preached with through the region. The fact that a painting of Francis appears to elicit the reconciliation is a powerful statement of belief in the saint's continued presence through images. ${ }^{384}$

The question remains, why is the dossal from Orte the only painting that expressly deals with the heretics so prevalent at that time, at least based on the few surviving examples? Francis himself may offer the rationale that the friars employed. Francis' ideas about engagement with heterodoxy were perhaps influenced by his life-long proximity to Cathar adherents. In the Earlier Rule, Francis' directions on the manner in which the

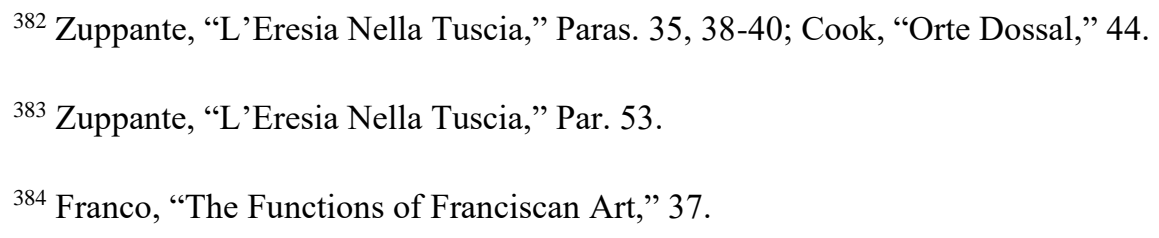


friars are to live as missionaries among Muslims and "non-believers" is a model of sensitivity and gentle example. He offers two guidelines:

One way is not to engage in arguments or disputes, but to be subject to every human creature for God's sake and to acknowledge that they [the friars] are Christians. Another way is to proclaim the word of God when they see that it pleases the Lord, so that they [the non-believer] believe in the all-powerful God-Father, and Son, and Holy Spirit. ${ }^{385}$

The Later Rule is less specific regarding the manner of engaging with non-believers, instead emphasizing that the friars should be devoted to the teachings and will of the Catholic Church and committed to poverty and humility. ${ }^{386}$ These guidelines mark the initial gentleness with which the Franciscans approached the Cathars. Zuppante appears to have come to the same conclusion. He notes, "Naturally the opposition of Francis to Catharism, if one can speak of opposition, was above all indirect and founded on the testimony given by his life and on pity for the 'human' sufferings of Jesus Christ, certainly not on repression." ${ }^{387}$ The small narrative panels that will be discussed next relate to themes of physical healing, the Catholic doctrines of the Incarnation and Real Presence, and the inherent goodness of the natural world. Through them, the vita dossals present a subtle explanation of orthodox beliefs that would have challenged the doctrine of the Cathars.

\section{Scenes of Physical Healing}

Signed and dated in 1235, Bonaventura Berlinghieri's dossal in Pescia, Italy, is the earliest of the extant composite panels (Figure 4.4). Its illustrations may have served

\footnotetext{
${ }^{385}$ Francis et al., Francis and Clare, 121.

386 Francis et al., Francis and Clare, 144.

387 Translation by the present author. Zuppante, “L'Eresia Nella Tuscia,” Par. 58.
} 
as models for many of the small narrative scenes. It depicts events based on the first biography by Thomas of Celano, written within three years of Francis' death in 1226 . Of the events featured, the stigmatization and the sermon to the birds occurred during Francis' lifetime, while the remaining four scenes are illustrations of posthumous miracles: the cure of the girl with a twisted neck, healings of people who were physically disabled or suffering from leprosy, an exorcism of demonic spirits, and the healing of Bartholomew of Narni. ${ }^{388}$ Following Berlinghieri's model, five other dossals include these same four stories about healing, indicating the importance of these reports to the order's legacy. They can be found accompanied by other narratives in Santa Croce in Florence, the Museo Civico in Pistoia, and the Museo Nazionale di San Matteo in Pisa. The dossals in the Tesoro in Assisi and the Pinacoteca at the Vatican contain only depictions of these miracles (See Catalog 2).

In addition to the promotion of Francis as a thaumaturge and of Assisi as a pilgrimage destination, each miracle presents Francis in his role of alter Christus, performing the same sorts of miracles that Jesus enacted. ${ }^{389}$ But beyond this characterization, the friars' visual focus on the physicality of those healed would have expressed a significant message to the dualist Cathar adherents who did not conceive of a connection between body and spirit after death. Twenty-eight of the small panels illustrate works Francis performed from beyond the grave, completed to demonstrate his power and influence continuing beyond this life. Francis' miracles post-mortem lay in

\footnotetext{
388 Two dossals, housed in Siena's Museo Nazionale and the Museo Diocesano in Orte discussed earlier, omit these miracles entirely, focusing on different issues. Ahlquist and Cook, "Posthumous Miracles," 217.

${ }^{389}$ Cook, "New Sources," 339; Franco, "Functions of Franciscan Art," 25.
} 
contrast to typical Cathar practice. Carol Lansing explains, "Perfects, after all, could offer no compassion, no miracles or aid in this life, but only a remote and austere afterlife." ${ }^{\prime 390}$ Records from several inquisitional hearings go further, reflecting Cathar doubt in an afterlife entirely. ${ }^{391}$

We will look more closely at depictions of two of Francis' miracles, reportedly performed following his death. The first presents a healing of a girl with a deformed neck that took place at Francis' tomb on the day of his burial (Figures 4.5-4.10). Thomas of Celano recounts,

She put her head for a little while beneath the coffin in which the precious body of the saint rested, and through the merits of that most holy man she was immediately able to straighten her neck, and her head was restored to its proper position. At this the girl was so overwhelmed at the sudden change in herself that she started to run away and to cry. There was a depression in her shoulder where her head had been when it was twisted out of position by her prolonged affliction (I Celano, Book 3, Chapter I) ${ }^{392}$

The eye-witness level amount of detail of the story, focusing on the physical aspects of the girl, are elaborated in the dossals. Each example presents the story at two different points in time. Taking Pescia as representative (Figure 4.5), we see that the small child lies beneath the saint's closed wooden coffin, her head shifted to her bare shoulder. Two friars stand behind the casket, which is raised on legs and is reminiscent of an altar. A decorated cloth appears to drape beneath it, and it is set with books, a pitcher, and a chalice. In all examples but the Bardi Dossal, the artist adds to the event the detail of a

\footnotetext{
${ }^{390}$ Lansing, Power and Purity, 132.

${ }^{391}$ Lansing, Power and Purity, 100.

392 Thomas et al., Francis Trilogy, 138.
} 
mother who brought her daughter, seeking a miracle. ${ }^{393}$ She kneels with her arms raised in supplication to the left of the coffin. Townspeople and friars witness the girl's recovery with looks and gestures of amazement. After an apparent passage of time, each illustration concludes with the mother carrying her child away on her shoulders. Such an explicitly physical and emotionally tender representation of mother and child would have also reflected the friars' promotion of orthodox teaching pertaining to the value of procreation. The Fourth Lateran Council confirmed marriage as a sacrament in defiance of dualist teachings. Canon One of the council declares, "Not only virgins and those practicing chastity, but also those united in marriage, through the right faith and through works pleasing to God, can merit eternal salvation."394 The Church taught that consummation of marriage completes the sacrament. ${ }^{395}$ Sermons preached by the Franciscan Servasanto da Faenza (active c. 1244-1285) reveal that these concurrently theological and physiological matters were dealt with by the friars. According to David D'Avray, "[Servasanto] contends that if something has a good end...then it too is good. But the end... of generation is to bring into the world children for the worship of God and to preserve in them the being that comes from God. This is a good end. So procreation

${ }^{393}$ In other dossals, the number of friars varies. The Vatican Pinacoteca panel has only candlesticks on the coffin. The Bardi Dossal differs by mixing the healing miracle with an exorcism, thus filling the space of the praying mother with a woman releasing evil spirits.

${ }^{394}$ Lateran Council and Fordham University Internet History Sourcebooks Project, "Medieval Sourcebook: Twelfth Ecumenical Council: Lateran IV 1215," accessed June 4, 2020, https://sourcebooks.fordham.edu/basis/lateran4.asp. For perceptions of marriage and childbearing, also see Ladurie, Montaillou, Chapters 8-12.

${ }^{395}$ Lansing, Power and Purity, 8-9. 
must be good." ${ }^{396}$ Many Cathars were not opposed to children, per se, as evidenced clearly by the population of the town of Montaillou; but on principle, D'Avray continues, "Souls were seen as good, bodies as bad. Sex perpetuated the chain of bodies." ${ }^{397}$ Sex resulted in children. The artwork of the friars supported the Church's position and gave the friars an illustration of this key rallying point.

The second narrative to be considered resulted in some of the most vibrant of the dossals' paintings. It is the depiction of the healing of Bartholomew of Narni (I Celano, Book 3, Chapter I) (Figures 4.11-4.16). Bartholomew was a poor beggar whose leg became twisted and numb, making it difficult to walk and causing great exhaustion. In a vision, he was told by Francis to visit a certain pool where he would be healed. After consulting with the bishop and being directed to comply with the vision, Bartholomew made his way through the night to the bath. He lost his way in the darkness and was guided back to the right path by a (presumably disembodied) voice. Entering the pool of water, the man felt one hand hold his leg while another hand extended his foot—curing him. Each portrayal of this scene shows Bartholomew reclining his entire body in a deep blue pool. His legs and torso are naked, and he carries his crutches into the water. Francis, in corporeal form, bends over the man and stretches his leg toward him. Thomas of Celano says that Bartholomew "jumped out of the pool, praising and blessing the allpowerful Creator and His servant, blessed Francis." ${ }^{398}$ Within the same scene,

${ }^{396}$ Omitted words: "(note the teleological thinking)...(i.e. the 'telos')" D. L D'Avray, Medieval Marriage, Medieval Marriage: Symbolism and Society (Oxford: Oxford University Press, 2008), 71-72.

${ }^{397}$ D’Avray, Medieval Marriage, 66.

398 Thomas et al., Francis Trilogy, 140. 
Bartholomew jauntily marches away, dressed and healthy, with crutches thrown over his shoulder. The textual source for the image addresses how the man was impacted by the natural elements: the darkness of the night sky causing him to lose his way and the waters of the pool providing a venue for the encounter. While not every element is illustrated, sermons about this scene could readily fill in details and interpret their meaning. For the painting, the focus remained on Bartholomew's physical form and the effect of the saint's healing touch.

Through his writing, Francis regularly encourages a physical connection that was further embraced and advocated by his order. ${ }^{399}$ Although stated within a message of selfdeprecation, Francis' Fifth Admonition reminds believers of the divine origin of their physical form: "Be conscious, O man, of the wondrous state in which the Lord God has placed you, for he created you and formed you to the image of his beloved Son according to the body, and to his likeness according to the spirit. ${ }^{~} 400$ This is in stark contrast to the Cathars' rejection of the human body's divine origin or its inherent potential for holiness. ${ }^{401}$ Walter Wakefield, in his analysis of the Summa contra haereticos by Franciscan preacher James Capelli, indicates that "The heretics...profess to abhor the idea that bodies which have natural deformities are fit to enter the heavenly kingdom." ${ }^{\circ 02}$ Francis did not shy away from people who possessed "physical deformities" such as

${ }^{399}$ Formulated in conversation with Fr. Wayne Hellman, OFM Conv.

${ }^{400}$ Irish Franciscans, “The Writings of St. Francis,” The Writings of Francis, accessed June 4, 2020, https://www.franciscans.ie/the-writings-of-st-francis/.

${ }^{401}$ Lansing, Power and Purity, 83.

${ }^{402}$ Wakefield, "Treatise Against Heretics," 50. 
paralysis, skin disorders, blindness, deafness, and diseases, neither during his lifetime nor, according to the brothers and their paintings, after his death. This acceptance, and hope for healing, served as a strong attractor for many people_-both believers and skeptics. In this regard, he also mirrored Jesus Christ.

While there are some examples of Cathars seeking miracles from deceased heretics or requesting Perfecti assistance in matters of health, there are many more instances of Cathars expressing their doubts about miracle-working saints. They would couch these complaints in cynicism at the righteousness of the saint and the genuineness of the healings. Often their disbelief stemmed from contempt of the clergy who presented the miracles. ${ }^{403}$ Yet there remained opportunities for conversion, as in the Umbrian town of Orvieto, where some Cathar venerated both the early Franciscan saint Ambrose of Massa and the Cathar Armanno Punzilupo, again reflecting the blended practice common during this period. ${ }^{404}$ I theorize that apostolic prospects such as these encouraged the friars to illustrate Francis' miracles that foreground physicality. The depictions of healing would have assisted the proselytizing efforts of the friars. The friar Servasanto was known to use exempla, moralizing stories or anecdotes, to encourage his audiences' memory of his homilies and increase their impact. ${ }^{405}$ Although earlier preachers had used

${ }^{403}$ See Lansing for accounts of Dominico Petri Rossi, Messer Rainerio Munaldi Rainerii Staphani, and Armanno Punzilupo of Ferrara. Lansing, Power and Purity, 104, 132-33.

${ }^{404}$ Lansing, Power and Purity, 77-78.

${ }^{405}$ Dansereau, Servasanto Da Faenza, 44-45. 
exempla, the Franciscans recognized their value and capitalized on their impact. Through their use, according to John Moorman, the friars "revolutionized the art of preaching.",406

Like the vade-mecum handbooks, the vita dossals can be understood as another

kind of preaching aid - a collection of visual exempla upon which the friars could expound. Dramatic images left an impression upon the viewer, a concept that will be discussed further in the next chapter. ${ }^{407}$ One of the most striking portrayals from the dossals is presented only once, found in the panel from Pisa. This illustration, based on III Celano, Chapter XII, is drawn from several posthumous miracles promoting the observance of the feast day of Francis. ${ }^{408}$ The Treatise on Miracles cautions:

In the town of Piglio in the province of Campania a woman busily went about her work on the feast of Saint Francis. A noblewoman sternly rebuked her for this since everyone should observe the feast out of divine reverence. She answered, "I only have a little of my work left to finish: Let the Lord see whether I'm doing wrong!" She soon saw the harsh judgment, in her daughter, who was sitting nearby. The girl's mouth twisted back to her ears and her eyes bulged, pitifully distorted. Women gathered quickly from all around and cursed the mother's ungodliness on account of the innocent daughter. The mother was overcome with sorrow and fell to the ground, promising to observe the feast annually, and further to feed the poor on that day out of reverence for the saint. Her daughter's troubles subsided without delay, once the mother had repented of her offense. ${ }^{409}$

${ }^{406}$ Moorman, History of the Franciscan Order, 277.

${ }^{407}$ Further research would need to include reception by the contemporary viewer of these particular images.

408 Pope Alexander IV's 1255 bull called on Christians to observe Francis' feast day under Church law. Ahlquist and Cook, "Posthumous Miracles," 242.

409 Thomas of Celano and Commission on the Franciscan Intellectual Tradition, Treatise on the Miracles, "The Treatise on the Miracles of Saint Francis," accessed June 4, 2020, https://franciscantradition.org/francis-of-assisi-early-documents/the-founder/the-treatise-on-the-miraclesof-saint-francis/1530-fa-ed-2-page-442; See also Thomas et al., Francis Trilogy, 360-61. 
In this story, the miracle is affected on a child again, although in the Pisa dossal she is depicted larger than her mother who stands behind and implores the saint's mercy (Figure 4.17). Francis, holding his typical book, gestures toward the girl with a blessing. The face of the child is the most impressive, and indeed most frightening, aspect of the illustration. She is facing the audience, with her eyes closed while shadowed-circles imply sunken and empty eye-sockets. Her large eyeballs hang down from veins, staring eerilycompellingly — at the viewer. How this image would have impacted the thirteenth-century audience is not known. Positioned as the middle scene of the column of images on the left side, the detail would have been quite small for a congregation to examine. However, if given the opportunity to contemplate this image after hearing the sermon, one might be more accountable to the friar's warning to commemorate Francis' feast day and cautious about ignoring the words of the brothers for fear of a similar physical retribution. ${ }^{410}$ The importance of restoring children to bodily health was emphasized in these healing miracles. As we turn to scenes dealing with the doctrine of the Incarnation and its relationship to the Eucharist, a child will once again figure prominently.

\section{Incarnation and Real Presence in the Eucharist}

Although the twelfth-century monk Bernard of Clairvaux had envisaged a comparable reenactment of the birth of Jesus, Francis is credited with initiating the tradition of the Christmas crèche. ${ }^{411}$ Thomas of Celano offers the narrative in his first

${ }^{410}$ For several interpretations of this miracle and its portrayal, see Ahlquist and Cook, "Posthumous Miracles," 241-43.

411 Thomas of Celano and Commission on the Franciscan Intellectual Tradition, "The Life of Saint Francis by Thomas of Celano: Vita Prima," accessed June 5, 2020, https://ranciscantradition.org/francisof-assisi-early-documents/the-saint/the-life-of-saint-francis-by-thomas-of-celano/698-fa-ed-1-page-254. 
vita, and Bonaventure repeats a shortened version in his Legenda Maior (See Appendices 3 and 4). In the story, which occurred three years before the saint's death, Francis requests his friend and honorable nobleman, John of Greccio, to prepare a place for the commemoration of Jesus' birth. Francis specifies, "For I wish to enact the memory of that babe who was born in Bethlehem: to see as much as is possible with my own bodily eyes the discomfort of his infant needs, how he lay in a manger, and how, with an ox and an ass standing by, he rested on hay."(I Celano, Book 1, Chapter XXX) $)^{412}$

Thomas of Celano continues the story, recounting the light of the candles and torches in the dark night, the hay that was laid in the manger, and the ox and ass that were brought into the area. The description of the setting in both textual accounts appears to be outdoors. Uniting humans and nature in the celebration, Thomas of Celano says, "The people arrive, ecstatic at this new mystery of new joy. The forest amplifies the cries and the boulders echo back the joyful crowd." ${ }^{\prime 13}$ Artists, however, expressed their own indoor vision of the background for their vita dossals - once in the Bardi Dossal on the left side, third scene from the base, and again painted for the church of San Francesco in Colle Val d'Elsa, which is now held in Siena. This example lies on the right, positioned second from the bottom (Figures 4.18-4.19) ${ }^{414}$ Both illustrations include architectural elements

\footnotetext{
412 Thomas of Celano and Commission on the Franciscan Intellectual Tradition; See also Thomas et al., Francis Trilogy, 94-97.

${ }^{413}$ Thomas of Celano and Commission on the Franciscan Intellectual Tradition, "Vita Prima"; Thomas et al., See also Francis Trilogy, 94-97.

${ }^{414}$ According to Cook, Siena's vita dossal is probably the only thirteenth-century example created after Bonaventure's Legenda Maior supplanted Celano's biography. The General Chapter of 1266 required Franciscan foundations to destroy their copies of all previous biographies of Francis, including Celano's texts. Cook, "Dossal in Siena," 4.
} 
that imply an ecclesial setting, although Thomas of Celano mentions a church being built only later at the site. ${ }^{415}$

While natural elements are highlighted in the text, the Nativity at Greccio artwork in Siena omits all aspects of the landscape save the two animals. The Florentine panel adds a golden mound which may be interpreted as a haystack at the manger. ${ }^{416}$ Instead of forest and stone, both depictions instead couple the nativity scene with the Eucharist. $I$ Celano briefly presents this detail: "Over the manger the solemnities of the Mass are celebrated and the priest enjoys a new consolation." 417 The unnamed priest presides behind a large altar that is set with a book and a chalice in the later dossal, but an area of paint loss appears to have deleted the vessel from the Bardi Dossal. For the first time, the Vita Prima mentions Francis' clerical role as a deacon. He stands at a lectern to fulfill his duties by singing the Gospel and preaching the sermon. In the Bardi Dossal, he is dressed in green and gold vestments, but he wears a brown habit in Siena.

The miracle treated in the paintings is not the establishment of the Christmas crèche — a theatrical and liturgical performance. Rather the miracle occurred when a nobleman witnessed the physical presence of the infant Jesus within the manger that had been filled only with hay. Celano reaches the climax of his tale:

...a virtuous man sees a wondrous vision. For the man saw a little child lying lifeless in the manger and he saw the holy man of God approach the child and waken him from a deep sleep... Now he is awakened and

415 Celano states, "At last, the site of the manger was consecrated as a temple to the Lord. In honor of the most blessed father Francis, an altar was constructed over the manger, and a church was dedicated." Thomas of Celano and Commission on the Franciscan Intellectual Tradition, "Vita Prima."

${ }^{416}$ The hay, Celano tells us, later becomes a sought-after medium for miraculous cures.

417 Thomas of Celano and Commission on the Franciscan Intellectual Tradition, "Vita Prima." 
impressed on their loving memory by His own grace through His holy servant Francis.

The Bardi Dossal shows the Christ Child attended by the ox and ass. Francis approaches the manger in the Siena dossal, kneeling at the infant's foot. He leans over slightly, at the very moment before he lifts the long-awaited newborn from the crib to embrace.

The Franciscan scholar Regis Armstrong asserts that Francis' Christological focus shifted attention more strongly toward the doctrine of the Incarnation leading up to this celebration at Greccio. ${ }^{418}$ The artwork of the early brothers subsequently relayed a strong message about Jesus' Incarnation, connecting his taking of a corporeal human form to symbolism of the Real Presence of the Eucharist. The iconography expresses the early friars' promotion of the Real Presence of Jesus manifested in the sacramental bread and wine of the Eucharist. The Cathars disputed this teaching of the Fourth Lateran Council most vehemently. Discussions concerning the meaning and process of the Eucharist took place throughout the thirteenth century - debates in which the Franciscans took an active part. ${ }^{419}$ It was a doctrine that Francis himself advocated. For example, in his First Admonition Francis declares:

All those who saw the Lord Jesus according to the humanity, therefore, and did not see and believe according to the Spirit and the Divinity that $\mathrm{He}$ is the true Son of God were condemned. Now in the same way, all those who see the sacrament sanctified by the words of the Lord upon the altar at the hands of the priest in the form of bread and wine, and who do not see and believe according to the Spirit and the Divinity that it is truly the Body and Blood of our Lord Jesus Christ, are condemned. [This] is affirmed by the Most High Himself Who says: This is my Body and the Blood of my new covenant [which will be shed for many]; and Whoever eats my flesh and drinks my blood has eternal life. It is the Spirit of the Lord, therefore, That lives in Its faithful, That receives the Body and

${ }^{418}$ Armstrong and Francis, St. Francis of Assisi, 177.

${ }^{419}$ Derbes, Picturing the Passion, 17. 
Blood of the Lord. All others who do not share in this same Spirit and presume to receive Him eat and drink judgment on themselves. ${ }^{420}$

By placing the Nativity at Greccio in the setting of a church during the sacrifice of the Mass, the friars reinforced orthodox teaching on the nature of the Eucharist as an extension of Jesus' Incarnation. The flesh of the Christ Child is the same flesh present in the Catholic sacrament. This is further underscored in the Siena dossal in which Francis nearly lifts the infant from his Romanesque manger-cradle. The potential energy of the action mirrors the elevation of the host during the Eucharistic ritual that the priest will momentarily enact above the manger. Depicting the instant just before intensifies the immediacy of the motion. The difference between Francis' role as preacher in the Bardi dossal and his embrace of the infant as Real Presence in Siena likely reflects the latter dossal's creation close on the heels of a miracle that took place in the nearby Lazian town of Bolsena. In this event, the communion bread appeared to bleed. This miracle led Pope Urban IV (r. 1261-1264) to proclaim the feast of Corpus Christi in Orvieto in 1264, which many have seen as a direct rebuke to Cathar heterodoxy. ${ }^{421}$ Rosalind Brooke describes the effect, saying, "The painting itself is a visual sermon, on the Nativity, and on Francis' success in arousing the hearts of men and women to ponder the human experience of Jesus." ${ }^{422}$ While we will revisit these ideas in the following chapter

${ }^{420}$ See Appendix 5 for the complete Admonition. Francis of Assisi and Commission on the Franciscan Intellectual Tradition, "The Admonitions," accessed June 6, 2020, https://franciscantradition.org/francis-of-assisi-early-documents/the-saint/writings-of-francis/the-undatedwritings/the-admonitions/144-fa-ed-1-page-128.

${ }^{421}$ Zuppante, “L’Eresia Nella Tuscia,” Par. 55; Lansing, Power and Purity, 162; Derbes, Picturing the Passion, 17-18; Biller, "Cathars and the Material," 90; Franco, "Functions of Franciscan Art," 41; Cook, "Dossal in Siena," 60.

${ }^{422}$ Brooke, Image of St Francis, 183-84; Also see Cook, "Dossal in Siena." 
discussing the wood-panel crucifixes, the Nativity at Greccio serves as the clearest illustration of these beliefs in the vita dossals. These two dogmas were antithetical to the Cathars' dualist and docetist beliefs, and the friars' devotion to them helped to spread Francis' charism through the populace. ${ }^{423}$

\section{Nature in the Vita Dossals}

While Francis, like the Cathar Perfecti, rejected material wealth and physical temptations, he was lovingly committed to nature. The poem, Canticle of the Creatures, is Francis' text which most directly counters the Cathars' hatred of all things material (Appendix 6). In this prayer, Francis calls on anthropomorphized Brother Sun and Sister Moon who radiate in the likeness of Jesus; Brother Wind and Sister Water who give sustenance and purity; Brother Fire who is beautiful and strong; and Sister Mother Earth who "sustains and governs us." ${ }^{\text {" }} 24$ God is praised through each of these creatures as well as by humanity who exists in cooperation with the elements. ${ }^{425}$ With the belief that all things stem from the divine source and are united, Francis connected on a familial level to all living beings and non-living objects—-whether a person, an animal, a plant, or a rock. ${ }^{426}$ Francis positively alludes to the scriptural story of creation in his poem, while the Cathars considered the book of Genesis to be the history of the Old Testament god,

${ }^{423}$ Dualism is a belief in the total division between spirit and matter. Docetism rejects that Jesus took a physical form. Lambert, The Cathars, 173.

${ }^{424}$ Francis et al., Francis and Clare, $38-39$.

${ }^{425}$ Armstrong and Francis, St. Francis of Assisi, 208; Rebecca Ruppar, "The Painted Panel Crucifixes of the Early Franciscans as a Response to the Cathar Heresy" (University of Missouri-Columbia, 2016), 77, https://mospace-umsystem-edu.proxy.mul.missouri.edu/xmlui/handle/10355/56131.

${ }^{426}$ Cook, "My Life with Francis," 237. 
whom they considered to be the devil—the source and ruler of evil. ${ }^{427}$ The friars singing of the Canticle to conclude each sermon, according to Zuppante, "must have sounded like a series of horrible curses in the ears of the Cathars. ${ }^{, 428}$ Unlike the dualist sect, the eloquence of the natural world seems to have affected the holy man profoundly, both in its beauty and its most humble and tragic forms. ${ }^{429}$ For Francis, the austerity of his chosen lifestyle was continuously balanced by the enjoyment of created reality. It permeated his charism and continued to influence the brothers as they created art to celebrate the poverello's teachings. ${ }^{430}$ Against the Cathars' anti-material stance, the Franciscans' promotion of the belief that the created world was not evil, or even neutral, but was in fact sanctified by the Divine could be explored in many of the dossals' narrative tableaux that feature visible creation. We will look at several key examples.

Francis' hagiographers describe his relationship with nature in great detail.

Thomas of Celano speaks of interactions with lambs, rabbits, worms, bees, wolves, trees, flowers, water, rocks, fire — and many others—indicating that Francis' treatment of them reflected respect and an understanding that they possessed some level of sentience. ${ }^{431}$ Bonaventure's description of nature is often more succinct, but in the Legenda Maior,

${ }^{427}$ Brenon et al., "Cathars and the Representation," 252.

${ }^{428}$ Translation by present author. Zuppante, “L’Eresia Nella Tuscia,” Par. 58.

${ }^{429}$ L. J Kiser, "The Garden of St. Francis: Plants, Landscape, and Economy in Thirteenth-Century Italy," Environmental History. 8, no. 2 (2003): 237-38.

${ }^{430}$ This concept developed in conversation with Fr. Wayne Hellmann, OFM Conv.

${ }^{431}$ Thomas et al., Francis Trilogy; Kiser, "Garden of St. Francis,” 231-32, 239. See Kiser for a list of example passages. 
Francis is shown to be generally focused on the splendor of the world and on witnessing to beauty itself. ${ }^{432}$

The preserved sermons of thirteenth-century Franciscans Servasanto da Faenza and Aldobrandino da Toscanella give textual examples of what the early Franciscans were thinking and preaching regarding nature during the same time the artwork developed. According to Raymond Dansereau's dissertation:

In the De virtuibus... Servasanto urges that the example of all creatures should incite man to a love of God as 'even dogs recognize their lords and benefactors and are faithful to them and die for them.' Just as animals are grateful to man for the benefits man gives, so too man should be grateful and love God for the many natural benefits that God gives including the benefit of the human body. ${ }^{433}$

David D’Avray quotes Aldobrandino da Toscanella (d. 1293) as the friar celebrates

creation while basing his thoughts in a teleological philosophy, saying:

'...natural things are delightful...Everything is a matter of delight in the time that belongs to it, like sweet wine in winter, dry wine in summer'. The same paragraph eventually leads into the Aristotelian idea that everything in nature strives towards the imperishable and the divine. Some things are imperishable in themselves so do not need to reproduce. Others have to achieve a sort of permanence by producing something like themselves. Thus 'it may be preserved in something which is like itself because of the divine being, and thus it conserves nature. ${ }^{434}$

Just as physicality and appreciation of natural beauty imbue Francis' own writing, so they permeate both the Franciscans' sermons and their artistic representations. ${ }^{435}$

${ }^{432}$ Idea formulated in conversation with Fr. Wayne Hellman, OFM Conv.

${ }^{433}$ Dansereau, Servasanto Da Faenza, 179.

434 D. L D’Avray, Medieval Marriage, Medieval Marriage: Symbolism and Society (Oxford: Oxford University Press, 2008), 71.

${ }^{435}$ Idea formulated in conversation with Fr. Wayne Hellman, OFM Conv. 
The illustration of Francis' Sermon to the Birds is one of the most widespread images of the saint. ${ }^{436}$ They are also the images that most clearly connect Francis to nature (Figures 4.20-4.23). Thomas of Celano tells this story in the Vita Prima and Bonaventure includes it also in the Legenda Maior (See Appendices 7 and 8): As Francis and several companions travelled through the Spoleto Valley near the town of Bevagna, they passed a place where there was a large congregation of various birds. ${ }^{437}$ I Celano describes them as doves, crows, and monaclae, which is a kind of shiny blackbird with purplish wings similar to a magpie. ${ }^{438}$ Bonaventure does not name the species but instead comments on their placement—some in trees and others on the earth. The four dossals render the birds in a variety of ways. Orte's and Siena's flocks rest on hilly ground; the former's appear undifferentiated, while Siena's shows the greatest mixture of size and plumage. Both scenes are positioned as the uppermost narrative illustrations, Siena's topping the left side, and Orte's - the right. They show Francis and only one other friar. In the dossals in Pescia and Florence, two companions travel with their leader in tableaux placed in the middle of the left hand columns. The friars witness a variety of birds spread over the trees and on the ground, although the branches of the Bardi panel are regimented into five horizontal rows.

${ }^{436}$ Franco, "Functions of Franciscan Art," 23.

437 Thomas of Celano and Commission on the Franciscan Intellectual Tradition, "Vita Prima"; See also Thomas et al., Francis Trilogy, 74; Bonaventure and Cousins, Bonaventure: Soul's Journey, 294-95.

438 Thomas of Celano and Commission on the Franciscan Intellectual Tradition, "Vita Prima." 
In this story, Thomas of Celano explains Francis' compassion “even toward lesser, irrational creatures." Francis enthusiastically approaches the flock and is surprised that they do not fly away. He asks them to listen as he evangelizes them, saying, My brother birds, you should greatly praise your Creator, and love Him always. He gave you feathers to wear, wings to fly, and whatever you need. God made you noble among His creatures and gave you a home in the purity of the air, so that, though you neither sow nor reap, $\mathrm{He}$ nevertheless protects and governs you without your least care. (I Celano, Book 1, Chapter XXI) ${ }^{439}$

The birds responded by stretching their wings and opening their beaks and allowed Francis to walk among them, his tunic brushing against their bodies and heads. He completed his sermon by blessing the birds with the sign of the cross and giving them permission to fly away. The brothers continued "along their way rejoicing and giving thanks to God, Whom all creatures revere by their devout confession." Recognizing he had been inattentive to their catechesis prior to then, Francis called on animals, birds, reptiles, and non-sentient beings to praise their creator from that point forward.

In the Legenda Maior, this tale follows Jesus' quandary about whether to either devote his life to contemplative prayer or apostolic preaching. He chooses the more active life. The image of the Sermon to the Birds has been understood as a representation of the mission of the order to preach the Gospel just as the apostles had — outdoors and to whomever would listen. ${ }^{440}$ Cook quotes Bonaventure in his further consideration of this scene. The Sermon to the Birds is also:

.... lesson from nature about how people should respond to Francis and by extension to the friars who are his brothers and imitators: 'A person would certainly have to be really perverse and obstinate to refuse to listen to

${ }^{439}$ Quotes and information in this section are found in Thomas et al., Francis Trilogy, 74.

${ }^{440}$ Cook, "Orte Dossal,” 42; Franco, "Functions of Franciscan Art,” 24. 
Saint Francis' preaching,' since creatures not endowed with reason did so. Thus, although the story is not central to an understanding of Francis or his order, I believe it retained its popularity in art at least in part because its meaning was changing so that it addressed contemporary concerns of the friars and their relationship with the laity. ${ }^{41}$

The "perverse and obstinate" people Bonaventure was referencing may have been not only the laity but also those outside the Church, namely the heretics.

Steven Runciman, a mid-twentieth century scholar of the crusades, proposed the "Franciscan doctrine of the animal soul," which the environmental philosopher Lynn White theorized Runciman had drawn from the Cathars' belief in reincarnation of fallen souls into human and animal bodies. ${ }^{42}$ White disputed this idea in his 1967 article, "The Historical Roots of Our Ecologic Crisis," and it was further rejected by Roger Sorrell and others who noted Francis' relationship to animals was based instead on a hagiographic tradition of saints being able to communicate with and control animals as a testament to their ascetic purity. Earlier saints such as Antony the Great and Jerome of Stridon had had similar encounters with wildlife. Francis' power over nature also envisioned a return to the prelapsarian state — when humans served as compassionate stewards toward all creation in the mythic Garden of Eden. ${ }^{443}$ The early Minorites' frequent commissioning

${ }^{441}$ Cook quotes Bonaventure in Cook, "Fraternal," 285.

${ }^{442}$ Lynn White, “The Historical Roots of Our Ecologic Crisis," Science 155, no. 3767 (March 10, 1967): 1207, https://doi.org/10.1126/science.155.3767.1203.

${ }^{443}$ Sorrell cites Steven Runciman, The Medieval Manichee: A Study of Christian Dualist Heresy (Cambridge, 1960), pp. 174, 179, 186. K. Esser, "Franziskus von Assisi und die Katharer seiner Zeit," AFH 51, 3 (1958), 225-264. Roger Sorrell, St. Francis of Assisi and Nature: Tradition and Innovation in Western Christian Attitudes toward the Environment (Milton Keynes: Lightning Source, 2010), 401; White, "Historical Roots," 1207; Kiser, "Garden of St. Francis," 124. 
of this scene confirmed and promoted Francis' acceptance of the created world as having a divine origin and therefore being inherently good. ${ }^{444}$

Beyond the birds, the vita dossals depict animals in five more narrative scenes. These are most often livestock as seen with the donkeys and oxen in the Nativity of Greccio (Figures 4.18-4.19), and two segments including sheep, goats, and pigs placed at the center-left lower section of the Bardi dossal. These images are based on two stories from I Celano, Book 1, Chapter XXVIII (Figures 4.24-4.25, Appendix 9). ${ }^{445}$ William Cook recognizes in this iconography scriptural references to the sacrificial lamb and the separation of the sheep and goats at the Last Judgment. In the traditional reading of the Bardi Dossal, beginning at the top left corner, these two pastoral scenes are positioned following episodes of Francis' preaching to the Sultan and to the Birds. In one panel, Francis holds a lamb, which Cook interprets as a symbol of a soul rescued by Francis’ preaching. It is lifted from amongst the other livestock the farmer is herding - the damned goats and unclean pigs. ${ }^{446}$ In the next section below, Francis offers his cloak to purchase two lambs that hang from a farmer's yoke on their way to market. The friars witnessing the events raise their hands in amazement. ${ }^{447}$

In his article, “The Garden of St. Francis: Plants, Landscape, and Economy in Thirteenth-Century Italy," L.J. Kiser, connects these lowly animals to the Franciscans'

${ }^{444}$ Brooke, Image of St Francis, 171.

445 Two bears can be found in the Siena Dossal which will be discussed later (Figure $\underline{4.26}$ ). Thomas of Celano and Commission on the Franciscan Intellectual Tradition, "Vita Prima"; Thomas et al., Francis Trilogy, 88-89.

${ }^{446}$ Cook, "New Sources," 328-29; Cook, "Fraternal," 285-86; Thomas of Celano and Commission on the Franciscan Intellectual Tradition, "Vita Prima"; Thomas et al., Francis Trilogy, 88-89.

${ }^{447}$ Cook, "New Sources," 330. 
mendicant lifestyle. Domestic animals, like the religious brothers, were reliant upon the charity of others to procure their food and shelter. Thomas of Celano's Vita Secunda offers additional accounts of Francis relating to and even identifying with animals as a demonstration of humility. ${ }^{448}$ Kiser explains, "Francis took pains to search for ways in which to abase himself, and, in doing so, he discovered humanity's undeniable affinity with its environment's most subordinate forms of life."449 Through these illustrations, Francis is shown to have the power to save not only through the Gospel he preaches but also the choices he makes on behalf of all creatures, modeling an environmental preferential option for the poor that prioritizes nature. The visualizations of Francis' power over creatures, but even more importantly his concern for animals, provided an orthodox parallel to the Cathars' understanding of created bodies as merely the evil receptacle for the transmigration of souls.

When considering the natural world as an integral feature of Franciscan art, it becomes necessary to discuss the shifts in representational approaches that inhabit artwork during the thirteenth century. This development stemmed from roots planted in the century prior and goes beyond art related to the Friars Minor. ${ }^{450}$ Classical Greek literature and illustrated manuscripts based on its philosophies enjoyed a resurgence in twelfth-century Europe, finding their way through Byzantine and Islamic interpretation and migration. The Aristotelian texts especially advocated empirical study of nature as

\footnotetext{
${ }^{448}$ L. J Kiser, “Animal Economies: The Lives of St. Francis in Their Medieval Contexts,” Interdisciplinary Studies in Literature and Environment Interdisciplinary Studies in Literature and Environment 11, no. 1 (2004): 126.

${ }^{449}$ Kiser, “Animal Economies,” 132.

${ }^{450}$ Goffen, Spirituality in Conflict, 25.
} 
essential to understanding the human condition and our place in the cosmos. ${ }^{451}$ Art historians such as Michael Camille, Herbert Kessler, and Madeline Caviness have acknowledged the encouragement of observation found in pre-modern nascent-scientific texts as motivation for a new variety of art in the thirteenth century. ${ }^{452}$ In Madeline Caviness' republication of her research, she walks back her attribution to Aristotle for Gothic naturalism saying, "I probably overstated the impact of Aristotle's study of nature outside the universities in the thirteenth century, because it is not clear how the new generations of professional artists would have accessed his concepts." ${ }^{453}$ Though further research is required, I would preliminarily argue in support of Caviness' original assertion by noting that academics such as Robert Grosseteste (1175-1253), and the Franciscans Roger Bacon (1214-1292) and John Peckham (1230-1292) may have served as potential conduits between what was being taught at the universities of Paris and Oxford and the order's patrons and artists. ${ }^{454}$ Based on the emphasis of proto-scientific scrutiny, in their writing, Francis' biographers, especially Thomas of Celano, sought eyewitness accounts for their vitae and sermons. Rona Goffen explains:

451 Jessica Rezunyk, "Science and Nature in the Medieval Ecological Imagination," Washington University in St. Louis, Washington University Open Scholarship Winter 12-15-2015: 8; Kessler, Seeing Medieval Art, 142.

452 See Michael Camille, The Gothic Idol: Ideology and Image-Making in Medieval Art, (Cambridge: Cambridge Univ. Press, 1989); Kessler, Seeing Medieval Art; Madeline H Caviness, Simple, "“The Simple Perception of Matter' and the Representation of Narrative, ca. 1180-1280," in Art in the Medieval West and Its Audience (Aldershot: Ashgate, 2002), III, 1-17; Jean A Givens, Observation and Image-Making in Gothic Art (New York: Cambridge University Press, 2004), 31.

${ }^{453}$ Madeline Harrison Caviness, Art in the Medieval West and Its Audience (Aldershot; Burlington USA: Ashgate, 2001), ix-x; also see Jean A Givens, Observation and Image-Making in Gothic Art (New York: Cambridge University Press, 2004), 31-33.

454 Though Robert Grosseteste was not himself a friar, he educated, supported, and influenced the Franciscans at the University of Oxford and as the bishop of Lincoln. Rezunyk, "Science and Nature," 2021; Kessler, Seeing Medieval Art, 143. 
Concern with recording the memories of those 'who were with' Francis perforce carried with it a concern about the specifics of time, place, and action: such naturalistic details give credence to the claim of representing eyewitness testimony. This, in turn, encouraged — indeed, demanded-a new naturalism in art, corresponding to the literary naturalism in the depiction of characters and events. ${ }^{455}$

The terminology for these questions becomes quite complex. In her book Observation and Image-Making in Gothic Art, Jean Givens differentiates "naturalism" from "realism" and "descriptive efforts." She defines naturalism as referring to "images that register the overall irregularity and variety inherent in living creatures." Realism "refers to art having a concrete historical reference or an apparent concrete historical reference." And finally, “'descriptive' images visually communicate information concerning the external and sometimes, internal physical structure of real-world objects and phenomena, but they need not be lifelike." ${ }^{456}$ Employing Givens' explanations, Franciscan art incorporates all three: naturalism, realism, and descriptive techniques. Returning to the narrative scenes in the vita dossals, a "naturalistic" depiction of Assisi can be observed in the Tesoro's version of the miracle of the girl with the twisted neck. Scholars have connected the townscape as representing not specific gates, towers, and houses, but an overall topographical picture of the medieval town (Figure 4.27). This can be compared to the "realism" expressed in the specific altars shown in the Tesoro's scenes of the exorcism and the healing of pilgrims — an altar detailed with rounded arches and hanging lamps that has been identified as the extant high altar of the Lower Basilica (Figures 4.28-

${ }^{455}$ Goffen, Spirituality in Conflict, 26-27.

${ }^{456}$ Givens, Observation and Image-Making, 101-2. 
4.29). ${ }^{457}$ The numerous landscapes depicted through the panels present "descriptive" images of mountains, caves, trees, and seas. The vita dossal of Siena, as our latest example, reveals the most sensitive representation of nature of the eight complex panels (Figure 4.26). Its presentation of the stigmatization is detailed with individual leaves on the trees, two ambling bears, and a variety of landforms and elaborate architectural features. Francis, both in the central panel and throughout this dossal, exhibits more accurate modeling and a greater level of expressiveness in his figure. While I would not argue for a strictly linear transition toward a greater naturalism, the Franciscans' attention to nature resulted in increasingly refined detail and authenticity for both figural representation and the setting in their artwork. Though they are not "life-like," the landscaped scenes of the vita dossals express the wild ruggedness of the region, impressing upon the viewer the dangers of the natural world into which the brothers ventured to bring the Good News (See Catalog 2).

In a meta-reference of the situation, the Franciscans' use of natural material (the wood-panel paintings) to depict such detailed representations of material (the created world) would have served as a double-effrontery to the Cathars. Within the materiality of the icons themselves - the wood structure, the cloth support, the egg-tempera paint, and the linseed oil varnish—-powerful spiritual ideas are conveyed through tangible and visible means. As we have seen in these chapters, the imagery displayed by the simple icons argued against the popularity of the heterodox Cathar leaders, setting up a visual comparison between Francis, the friars, and the Perfecti. The marquee image of the poverello would have attracted attention in public spaces, affording the brothers many

${ }^{457}$ Brooke, Image of St Francis, 174-75; Caviness, "Simple Perception," 3. 
opportunities to elaborate on the orthodoxy to which the saint had dedicated his life. Francis'status_- promoted as another Christ—encouraged the audience to a deeper appreciation and mirroring of his holiness. The vita dossals elaborated on these themes, offering their stories as visual exempla. The physicality of Francis' miracles, the doctrinal teaching emphasizing the work of the Fourth Lateran Council, and the appreciation of nature worked together with the central representation of Francis to educate and inspire the viewer. In the next chapter, we will explore how these same physical and spiritual concepts manifested in the dipintura crucifixes of the Friars Minor. 


\section{Chapter 5 Countering Heresy through the Theology and Materiality of the Painted-Panel Crucifixes}

As discussed in the previous chapter, two interrelated factors contributed to the increasingly detailed and accurate representation of natural forms in Franciscan artwork: first, the brothers' emphasis on the inherent goodness of the created world, and, second, their adoption of Aristotelian philosophy in support of empirical observation. Michael Camille expresses the belief that "It is not just that Gothic art as a style looks more 'naturalistic,' but that nature itself becomes an integrated myth of meaning in the elaboration of its structure." 458 This renewed appreciation of and attention to nature was fleshed out (figuratively) in images of the Crucifixion. It is my contention that the motivation of the Franciscans to incorporate more naturalistic renderings of this key moment of the Gospel was the perceived need to re-educate the Christian faithful in the central dogmas of their religion in a compelling, even impassioned, way. They focused especially on the doctrines of the Incarnation and the Real Presence of the Eucharist, the dual nature of Jesus as both divine and human, and the importance of the Passion in Catholic theology - those orthodox beliefs that Cathars preached against most forcefully.

In this chapter, I will consider the ten remaining panels in my study, monumental painted-panel crucifixes that depict Francis of Assisi as a witness to Jesus' crucifixion, standing or kneeling beneath the cross (See Catalog 3). All the crucifixes under consideration are imposing in size — nearly two meters in length by at least one and a half meters in width. Initially, they were positioned in prominent locations in churches. While

${ }^{458}$ Michael Camille, The Gothic Idol, 199. While Camille discusses this organic and realistic form in terms of architecture, it can readily be applied to the shift in the depiction of the human form as well. 
they did not always remain in their original site, they were not intended to regularly move in procession or pilgrimage unlike the vita dossals and icons. These crosses feature the suffering Christ, or Christus Patiens, depicting Jesus' abused body very near to or immediately following his death. ${ }^{459}$ We will begin by examining the history of painted wood-panel crosses in Italy and their adaptation from Byzantine precursors. We will then look to the placement of the crosses within church architecture. To examine the role these crosses played in the Franciscans' resistance against the Cathars, I will address how their various iconographic elements implicitly challenged the core heterodox beliefs through the graphic depiction of physical and emotional suffering. I intend to elaborate on the capacity of the evolving naturalism of form to evoke viewer emotion and support orthodox religious belief as a counter to the Cathar movement.

Cathars firmly opposed the Catholic veneration of crucifixes. The Perfectus Guilhem Bélibaste gave a sermon in which he protested, "If your father had been hanged on a tree, would you love that tree? In the same way, since the son of God was nailed to the cross, we must not love the cross but hate it, and if possible break it." ${ }^{460}$ In the midthirteenth century, James Capelli had noted Cathars relaying this same idea in his Brevis summula. He continues, "Also, they say that those who adore the cross should, with equal right, adore all thorns and all lances, for just as in Christ's passion the Cross was for His body, so the thorns for His head and the soldier's lance for His side."461 Cathars,

${ }^{459}$ Derbes, Picturing the Passion, 4-5.

460 Arnaut Sicre's testimony before Jacques Fournier quoting Guilhem Bélibaste's sermon, in Brenon et al., "Cathars and the Representation," 251.

${ }^{461}$ Wakefield and Evans, Heresies, 384. 
however, did not believe that Jesus had suffered through the Crucifixion — his body being mere illusion and his redemptive work on earth purely spiritual. Nevertheless, a cross signified a tool of Lucifer, a means of physical pain and execution. Therefore, they believed one should neither create nor adore this symbol. ${ }^{462}$

Long before the Franciscans, the visual focus for churches in Italy was the image of the crucifix. ${ }^{463}$ The earliest known Italian painted panel crosses were created in or near Pisa. The Cross of Maestro Guglielmo in the Cathedral of Sarzana (1138) serves as the oldest extant example of a monumental painted panel cross (Figures 5.1- $\underline{5.2}$ ). ${ }^{464}$ This crucifix portrays Jesus as the Christus Triumphans. In this format of the crucifixion, Jesus appears immune to suffering and death. He stands against the cross fully alivedespite the spear wound. His eyes are open and his face devoid of emotion. The main figure is surrounded by a stoic Mary, John the Apostle, and other bystanders, as well as smaller scenes of the Passion on the apron, or tabellone. The original position of this piece is unknown, as it has been moved several times and the church has been remodeled extensively.

Very similar to the Cross of Maestro Guglielmo, the Cross of San Damiano (Figure 5.3) is dated to the late twelfth century, when it was created in the Christus

462 Brenon et al., "Cathars and the Representation,” 251-52.

${ }^{463}$ Neff, "Painting, Devotion, and the Franciscans," 38.

${ }^{464}$ Derbes, Picturing the Passion, 36; Rice, Byzantine Painting, 76; for information on the most recent restoration of this crucifix, see Ciatti, Pinxit Guillielmus - il restauro della Croce di Sarzana; and Giuseppina Mormandi, "Il culto della Santa Croce nella diocesi di Luni-Sarzana," Giornale storico della Lunigiana e del territorio lucense / Istituto Internazionale di Studi Liguri, Sezione Lunense, La Spezia; Sezione Lucense, Lucca., 2016. 
Triumphans style by an anonymous north Umbrian artist. ${ }^{465}$ Thomas of Celano's Second Life tells of a mystical event Francis experienced in the presence of this artwork in the dilapidated church of San Damiano near Assisi. Praying as he lay beneath the paintedpanel crucifix, Francis heard a voice coming from the image of Jesus on the cross. It told him three times, "Francis, go and repair my house which, as you see, is falling completely into ruin." ${ }^{466}$ Francis understood the words he heard to be the voice of God emanating from the painted panel. This phenomenon shaped the remainder of Francis' life and ministry. Francis continued to focus on the suffering of Jesus at the Crucifixion and based his preaching on the Passion. The event at San Damiano continued to inspire the Franciscan order and influenced the subsequent artwork it produced. As the basis of our exploration of the dipintura crucifixes, we will first study that very painting, the Cross of San Damiano, which is credited with motivating Francis and is still preserved in the convent of the Poor Clares, the order of cloistered sisters that Francis began with his friend and follower Clare of Assisi.

The Cross of San Damiano is considered an historiated cross, an iconographic type in which smaller scenes of Jesus' Passion surround the central, large, imposing figure of the corpus. ${ }^{467}$ Rather than appearing slumped over in death, attached to the

${ }^{465}$ For recent work on the Cross of San Damiano, see Sergiusz M. Bałdyga, The San Damiano Cross (Assisi: Edizioni Porziuncola, 2005); Milvia Bollati and Carlo Fadin, Francesco e la Croce di S. Damiano, Fonti e Ricerche 25 (Milano: Edizioni Biblioteca Francescana, 2016); Letizia Pani Ermini et al., Indagini archeologiche nella chiesa di San Damiano in Assisi (S. Maria degli Angeli, Italy: Porziuncola, 2005).

${ }^{466}$ Bonaventure and Cousins, 191. Elvio Lunghi points to the vita of St. Bernard in the Cistercian tradition as an hagiographic example for miraculous interactions with crucifixes. Lunghi, "Francis in Prayer," 349.

${ }^{467}$ Derbes, Picturing the Passion, 4-5. 
wood, the image of Jesus stands erect as if floating in front of the cross. With his rosycheeked head raised and almond-shaped eyes open wide, this Christ appears quite communicative. ${ }^{468}$ His body is unblemished except for a discreet wound on his right rib cage, nearly beyond sight around his side. It is interesting to note that in the Passion narrative, the side was pierced by the soldier's spear only after Jesus had expired on the cross, yet here he stands fully alive. Around the nails in the hands a starburst of blood can be seen, flowing to the elbows and then dripping down onto two more angels beneath each arm while a final two angels stand at the end of the arms of the red bordered cross. The angels converse nonchalantly, gesturing toward Jesus. His hips are barely turned to his right and are covered with an opaque white and gold cloth, intricately tied with a three-part knot below his navel. The legs are straight, and his feet are pierced separately by two nails; blood erupts from the feet and the hands in stylized radiating drops.

The apron of the cross depicts scenes of Jesus' Passion and his healing ministry. Flanking Christ, and about a third of his size, are his mother Mary and John the Apostle on his right, and on his left stand Mary Magdalene, Mary the mother of James and Joseph, and the centurion. ${ }^{469}$ Each is labeled beneath the figure. Three smaller people, approximately one-sixth the height of Jesus, look on from the edges of the crowd. Above the shoulder of the centurion can be seen a small head. This is thought to be the centurion's son whom Jesus healed. Behind him are three additional tops of heads

\footnotetext{
468 The crown of thorns is absent. This instrument of the Passion is typically not represented in Crucifixion imagery until the middle of the thirteenth century. Paul Thoby, Le Crucifix, des Origines au Concile de Trente: Étude Iconographique (Nantes: Bellanger, 1959), 156.

469 The centurion may be holding a fasces, or staff of authority.
} 
representing the household of the centurion. ${ }^{470}$ The person on the viewer's left is labeled as Longinus, traditionally the name of the soldier who pierced Jesus' side with a lance. Opposite him may be Stefatus, the soldier who offered Jesus the sponge soaked in vinegar. ${ }^{471}$ Alternately, this unlabeled figure may be Joseph of Arimathea or Nicodemus, as the figure is older, bearded, and non-uniformed.

The disembodied hand at the top of the cross represents God the Father granting his blessing. In the cimasa, the small T-shaped section at the top of the cross, Jesus stands as the resurrected Christ holding a cross scepter amidst ten angels. Below this is a plaque with Jesus' name abbreviated to its first three letters in Greek: IH $\Sigma$. The line above the letters indicates the use of a contraction. In full, the text reads: "Jesus the Nazarene, King of the Jews," as described in the Gospel accounts. Beneath Jesus' bleeding feet is a row of haloed saints. While badly damaged, these saints have been assumed to be local patron saints of Assisi: Damian (to whom the church in which the cross originally stood was dedicated), Rufinus, Michael, John the Baptist, Peter, and Paul. ${ }^{472}$

This iconographic type of Jesus' crucifixion, known as the Christus Triumphans, has a long tradition in Byzantine art. Hans Belting explains that Psellus, an eleventhcentury chronicler of Constantinople, describes the Christus Triumphans icons of the

${ }^{470}$ The representation of the centurion is based on John 4:51-53. After Jesus healed the centurion's son, the man dedicated the faith of his household to Jesus.

${ }^{471}$ Derbes, Picturing the Passion, 4-5; Rebecca Ruppar, "The Painted Panel Crucifixes of the Early Franciscans as a Response to the Cathar Heresy" (Master's Thesis, Columbia, Missouri, University of Missouri, 2016), 21-23.

472 The current author presented an alternate theory on the identity of the saints represented in this section of the Cross of San Damiano in Rebecca Ruppar, "Cross Cult[Ural]: The Cross of San Damiano and the Earlier Saints of Assisi," in Vernacular Theology and Medieval Franciscans (The Franciscan Institute, St. Bonaventure University) (54th International Congress on Medieval Studies, Western Michigan University, Kalamazoo, Michigan, 2019). 
Crucifixion as an effort to relay the atemporal paradox of '“then' and 'now,' the event and its depiction." He believes this is effected by painting great beauty but at the same time presenting Jesus "living, at his last breath." While the image includes the side wound of Jesus, which occurred after his death, Belting clarifies that this paradox relays a cessation of the rules of earthly time. "The image is intended to be not a narrative but a unity of ideas." ${ }^{973}$

Francis accepted literally the mystical directive that he believed was given to him by the Cross of San Damiano to repair Jesus' church. Working along with his newly established brotherhood, he prepared the dilapidated building of San Damiano to become the home of Clare and her sisters. The structure remained their convent until 1257, at which time they moved - along with the crucifix - to the Church of San Giorgio in Assisi. The cloister of the Poor Clares and the Basilica of Santa Chiara were built to incorporate the existing chapel. The Cross of San Damiano was displayed to the modern public for the first time in $1957 .{ }^{474}$

In her book Picturing the Passion in Late Medieval Italy, Anne Derbes proposes that the shift from the Christus Triumphans to the Christus Patiens style of crucifix is one of the greatest artistic transitions to occur during the thirteenth century. ${ }^{475}$ At least thirty monumental wood-panel crosses are known to have originated in Franciscan foundations

${ }^{473}$ Belting, Likeness and presence, 271.

474 "Il Crocifisso di San Damiano Torna (Temporaneamente) a 'Casa': le Foto," AssisiNews, June 15, 2016, https://www.assisinews.it/speciali/crocifisso-di-san-damiano-torna-casa-foto/.

${ }^{475}$ Derbes, Picturing the Passion, 4-5. 
of the thirteenth century. ${ }^{476}$ Derbes explains, "These crosses fuse icon and narrative; here the viewer at once contemplates the body of Christ and reads the events leading to this death on the cross." ${ }^{\prime 477}$ Franciscans have been recognized as influential for the spread of the Christus Patiens motif, but according to Derbes, their wider impact on Passion imagery had not been observed prior to her groundbreaking research. Derbes' study explores the manner in which the historiated panels move from depicting an even distribution of Passion and Resurrection images alongside the triumphant Jesus to scenes focusing almost exclusively on the suffering and death of Jesus flanking the Christus Patiens. ${ }^{478}$ Our present study examines the Franciscans' motivation that led to this iconographic development.

Francis of Assisi internalized the doctrinal teachings that were prominent during his era, especially in regard to Incarnational and Eucharistic theologies. The Council of Chalcedon (451) had proclaimed the dual nature of Jesus as true God and true man: "Like us in all respects apart from $\sin .{ }^{, 479}$ In earlier periods, in efforts to counter Jewish, Arian, and Islamic beliefs, Christian theologians and artists found it necessary to focus on the divinity of Jesus. But by the thirteenth century, particularly in the western Church, the pendulum had swung to the point where Christ's godliness was taken for granted and it

${ }^{476}$ In comparison, the Dominican order was responsible for only four to five examples from this same time. Joanna Cannon, "Reviews of Exhibitions: The Era of the Great Painted Crucifix: Giotto, Cimabue, Giunta Pisano, and Their Anonymous Contemporaries," Renaissance Studies 16, no. 4 (2002): 578.

${ }^{477}$ Derbes, Picturing the Passion, 4.

${ }^{478}$ Derbes, Picturing the Passion, 7, 23.

${ }^{479}$ Leo Steinberg, The Sexuality of Christ in Renaissance Art and in Modern Oblivion (New York: Pantheon Books, 1983), 19. 
was his humanity that was questioned in heterodox circles. Steinberg argues that, “...for a Western artist nurtured in Catholic orthodoxy-for him the objective was not so much to proclaim the divinity of [Jesus] as to declare the humanation of God." 480 To meet this current need Franciscans stressed the physicality of Jesus, focusing their devotions on Christ's suffering and death as well as on his Incarnation through Mary. ${ }^{481}$ Lambert explains: "St. Francis of Assisi played a major role in the development of a piety focused on the Holy Family and the humanity and sufferings of Jesus. This worked powerfully against the menace of Catharism, of which he [Francis] was more aware than is commonly supposed." 482 We will now examine this artwork that was so effective in the friars' mission.

\section{The Original Franciscan Cross and its Environs}

According to Elvio Lunghi, the entire character of Franciscan art is based on the Basilica of San Francesco in Assisi. ${ }^{483}$ Following centuries-old tradition, the Upper Church of San Francesco was built in a cruciform shape with its long nave oriented along an east-west line. Its transept contained the high altar, and a side altar was situated in each arm. Wooden choir stalls for the friars lined the sides of the apse with a papal throne at the center. ${ }^{484}$ A tramezzo screen, similar to Byzantine iconostases, possibly divided the

${ }^{480}$ Steinberg, The Sexuality of Christ, 10-11.

${ }^{481}$ Lambert, The Cathars, 288.

${ }^{482}$ Lambert, The Cathars, 1.

${ }^{483}$ Lunghi, "Francis in Prayer,” 344.

62.

484 This papal throne was installed by the 1280s. Cooper and Robson, The Making of Assisi, 56, 
lower nave where the laity worshipped from the choir area where the friars would gather closer to the high altar. ${ }^{485}$ According to Marcia B. Hall's research from the 1970 s as well as her current work, most tramezzi were dismantled by the sixteenth or seventeenth century and were, for the most part, forgotten as an element of Roman rite architecture. ${ }^{486}$ The screen, usually a masonry construction, served as a focal point for contemplation during the Mass while only glimpses of the altar could be seen through the open colonnade. Thus it aided in preserving the mystery of the sacrament. In Assisi, foundations are in place beneath the floor which would have been able to support a masonry screen. The tramezzo in the basilica of San Francesco seems to have been demolished by the 1290s in order for the fresco cycle by Cimabue to be painted in the nave without spatial disruption. ${ }^{487}$

The oldest known crucifix created for the Franciscan order sat atop the tramezzo's uppermost crosspiece. Giunta Pisano of Pisa (c. 1180-1258) executed this panel-painting under the direction of Elias of Cortona, the vicar general of the order from 1221-1227 and later minister general from $1232-1239$. The crucifix is dated to 1236 by record of an inscription that is accepted as authentic, and it was placed on the tramezzo upon

${ }^{485}$ Tramezzi were utilized solely in monasteries and churches built by religious orders in Italy. The screen also served to segregate the worship space by gender. In most liturgical situations, women remained in the lower nave while men could enter beyond the screen. However, women are documented as being permitted in the Upper Basilica's altar area during non-liturgical times. Cooper, "Experiencing Dominican," 50.

${ }^{486}$ Marcia B. Hall, "The Tramezzo in the Italian Renaissance, Revisited," in Thresholds of the Sacred: Architectural, Art Historical, Liturgical, and Theological Perspectives on Religious Screens, East and West, ed. Sharon E. J. Gerstel (Washington, D.C: Dumbarton Oaks Research Library and Collection, 2006), 216.

${ }^{487}$ Cooper and Robson, The Making of Assisi, 62. 
completion of the church's construction in $1253 .{ }^{488}$ It is known only from written descriptions and a seventeenth-century print drawn from the original (Figure 5.4). Alberto Lunghi proposes that the late seventeenth-century painter Francesco Providoni's Brother Elias before the Crucifix also offers a reflection of the donor's portrait. ${ }^{489}$ Based on this evidence, we can compare an extant crucifix from the same time period that Pisano created on a smaller scale for the church of Santa Maria degli Angeli. Also called the Porziuncola, or Little Portion, the original church at this site served as the home of Francis and the early friars (c.1230-1240) (Figure 5.5).${ }^{490}$ Both crosses are examples of the Christus Patiens style, depicting the deceased corpus of Jesus. In the Porziuncola's cross, the curving torso of Jesus stands against a simple tabellone that is decorated with a geometric patterned ribbon. Half-length portraits of Mary and John the Apostle look toward Christ at the center. A small rondo depicting Christ as the Savior of the World crowns the top. Unlike the cross at the Porziuncola which does not depict any figure at the feet of Christ, for the Basilica of San Francesco, Pisano utilized a popular Italian convention of inserting a founder or donor image of Elias at the foot of the cross. ${ }^{491}$ Most likely positioned in an easily accessible area of the Upper or Lower Basilica until it was raised to the tramezzo, this cross inspired numerous monumental crucifixes throughout

488 The text on Elias' cross reads: "Frater Elias fecit fieri/ Jesu Christe pie/ Miserere precantis Eliae/ Juncta Pisanus me pinxit/ Anno Domini MCCXXXVI/ Indictione Nona” Translated: Brother Elias made it / Jesus Christ [have] mercy / Pray for Elias [Have a prayer for Elias?]/ Giunta Pisano painted / year of 1236 / ninth indiction. Cooper and Robson, The Making of Assisi, 63, 65; Lunghi, "Francis in Prayer," 344.

${ }^{489}$ The artist Francesco Providoni was active 1685-1696. Lunghi, “Francis in Prayer,” 345.

${ }^{490}$ Kennedy et al., Sanctity Pictured, 6.

${ }^{491}$ Unless otherwise noted, this section on the Upper Basilica is taken from Cooper and Robson, The Making of Assisi, 64-72. 
the region. No other minister general mimicked Elias' donor figure though. Instead, representations of Francis took Elias' place at the foot of subsequent crosses. It is possible that the details of the image and the accompanying inscription identifying both artist and donor were illegible once the cross was in place above the nave. Later iterations may have assumed the small friar at Jesus' foot in Pisano's cross was in fact the order's founder. It will become clear that the later theological treatises and mystical essays of the Franciscan order were inextricably linked to the design of his innovative crucifix. ${ }^{492}$

Pisano's crucifix in the Upper Basilica of San Francesco was possibly as large as five meters in height, taking up a substantial part of the nineteen-meter elevation from floor to the peak of the vault. ${ }^{493}$ Seventeenth-century descriptions suggest its size was colossal. The monumental cross stood atop the upper crossbar, or epistyle, of the tramezzo until 1622 when it was removed to improve the sight lines for an elevated seating area in the nave. The cut ends of the beam remain visible in the walls, jutting out of the frescoed scenes painted by Cimabue. At this point, Pisano's cross was repositioned under the rose window in the eastern façade. There it suffered exposure to the elements through broken window panes above. A seventeenth-century friar mentioned the cross' poor condition in 1683; and the last account indicates that it fell and broke in the eighteenth century, with no further mention past 1785 .

There is mention of two other panel paintings atop the tramezzo in San Francesco. Both were attributed to Giunta Pisano in seventeenth-century texts. One is described as a Pentecost scene of the Holy Spirit descending upon Mary and the apostles. The other

${ }^{492}$ Baldini and Casazza, Crucifix by Cimabue, 21.

${ }^{493}$ Unless otherwise noted, this section on the Upper Basilica is taken from Cooper and Robson, The Making of Assisi, 63-72, 75, 82. 
depicted the Archangel Michael battling Lucifer. These themes related to the dedications of the side chapels in the transept arms. The backdrop for the tramezzo panel paintings in San Francesco would have been the set of three stained glass windows composed of two lancets each that remain in the Upper Basilica. They present scenes of the life of Christ from the New Testament paired with the Old Testament stories that prefigured themcreating a framework of salvation history centered on the cross. Their mid-thirteenth century dating makes these apse windows among the earliest use of stained glass in Italy. Above the windows, the vaults were painted a canopy of cerulean blue with golden stars. A further program of frescoes depicting the four evangelists filled the space above the choir in the apse, but these vaults would not have been visible from the congregation's sightlines in the nave.

The arrangement of three panel paintings spread across the top of an epistyle beam or tramezzo may have been frequent in thirteenth-century Italian sanctuaries. We can see Cimabue's rendition of how these liturgical spaces were organized in two scenes from his frescoes in the nave of San Francesco. ${ }^{494}$ While it is believed that Cimabue's frescoes do not portray any actual set of panels, they reflect the use of panel paintings common to the period's monastic churches. ${ }^{495}$ The fresco Verification of the Stigmata (Figure 5.6) shows three dipinti from the perspective of viewers in the nave; while the scene of the Miracle at Greccio (Figure 5.7) presents the view of a tramezzo from the choir area, showing only the cross atop the screen. With its comparatively small size, the crucifix in the Nativity at Greccio is supported by a wooden scaffold which provides a

\footnotetext{
${ }^{494}$ Kennedy et al., Sanctity Pictured, 5.

${ }^{495}$ Cooper and Robson, The Making of Assisi, 74.
} 
counter-weight. ${ }^{496}$ The large monumental crosses, such as Pisano's in San Francesco, may have additionally been supported by chains from the vault above or from beams in the roof. ${ }^{497}$ The crosses of the early Franciscans grew to a massive scale, far surpassing the size depicted in Cimabue's paintings. ${ }^{498}$ The average size for the extant thirteenthcentury crucifixes in this study measures 2.69 meters in width by 3.71 meters in height. ${ }^{499}$ It is probable that the prototype cross by Giunta Pisano more than doubled the dimensions of the Cross of San Damiano that inspired Francis.

\section{Byzantine Framework}

We have already considered the Byzantine influence on the simple icons and vita dossals of the Franciscans. We will now look at how the East shaped the crucifixes that were so prominent in Franciscan sanctuaries. In his 1968 book Byzantine Painting: The Last Phase, David Talbot Rice draws a comparison between Giunta Pisano's monumental cross in the Basilica of San Francesco and the Crucifixion wall painting in the Church of Nemanja in the Studenica Monastery, created in 1208 (Figure 5.8), as well as a similar rendition at the Church of the Resurrection in the Žiča Monastery, both near Kraljevo, Serbia, painted between 1219 and 1230 (Figure 5.9). Rice explains that Italian painting at the turn of the thirteenth century appears static and detached, seemingly oblivious to the shifts toward naturalism and emotion that occurred in the period of Byzantine

\footnotetext{
${ }^{496}$ Derbes, Picturing the Passion, 18.

${ }^{497}$ Cooper, “Experiencing Dominican," 51.

${ }^{498}$ Although outside the subset of crosses examined in this study, some extant examples of Italian medieval crosses measure nearly six meters in height. Cooper and Robson, The Making of Assisi, 66.

${ }^{499}$ See Catalog 3 for dimensions of each cross. This calculation of average size eliminated the measurements of crosses whose termini were cut down.
} 
revitalization, most of the evidence for which can be seen in the Balkans, or in new trends in Germany or France. ${ }^{500}$ The Maniera Greca (Greek Manner), which was a style considered tired and worn by the sixteenth-century artist and writer Giorgio Vasari, can be held in contrast to the progressive Greek Revival style occurring in the Balkans immediately prior to the early Franciscans. Rice believes that the Crucifixion images in Studenica and Žiča are not entirely Byzantine in style though. He describes these frescoed examples as "something new in Byzantine art." ${ }^{, 501}$ Rice goes so far as to say that the similarity between these portrayals and Giunta Pisano's crucifixes demonstrates an association between Serbia and Italy, possibly even an immediate connection to Pisano (active c. 1206-1236). Rice holds that despite earlier models of the Christus Patiens in Germany (for example the Gero Cross in Cologne), the crucified corpus at Studenica with its twisted body, bent head, and closed eyes and must be considered the precedent for the iconography that spread throughout the western Balkans and Italy.

The history of the Cathars could also play a role in this theory, as the immediate religious predecessor of Catharism, Bogomilism, was a strong and widespread movement in Serbia during the late twelfth century. The Bogomils' organization of their dualistic religion in the Balkans - with advanced hierarchical, communal, and ritual structureseased the development and diffusion of the Cathars in Serbia, and perhaps later the move into northern Italy. They were not a welcome influence however, and the rulers of Serbia, including Stefan Nemanja and his descendants, used military force to root out the

500 Unless noted, information in this section is drawn from Rice, Byzantine Painting, 40, 46-47, 76,81 .

501 Rice, Byzantine Painting, 46-47. 
adherents including tactics such as forbidding their teaching, exiling, and executing the followers. ${ }^{502}$

The Princeton-Michigan expeditions to Mount Sinai (1956-1965) led by Kurt Weitzmann brought to light many previously unknown icons from the Byzantine period, providing even earlier prototypes of the Crucifixion images under discussion. In the Monastery of St. Catherine, the oldest known extant rendition of a painted Christus Patiens can be found on an epistyle beam that is believed to have been created at Mount Sinai in the early twelfth century. It depicts the dead Christ in a pose nearly identical to that of the Studenica fresco. The original beam, measuring approximately 4.75 meters in width by .40 meter in height, has been divided into four separate planks that are currently housed in two chapels of the Monastery of St. Catherine. Considered together, it presents one of the oldest complete depictions of the Dodecaorton, or the Twelve Great Feasts of the Byzantine Church. In the Chapel of Constantine and Helena, the illustrations include the Entry into Jerusalem, the Christus Patiens Crucifixion, and the Harrowing of Hell on the first board (Figure 5.10). The Ascension, Pentecost, and Dormition of Mary are on the second (Figure 5.11). Located in the Chapel of St. George, the third section depicts the Baptism of Christ, the Transfiguration, and the Raising of Lazarus (Figure 5.12); and finally the Annunciation, the Nativity, and the Presentation of Jesus (Figure 5.13). ${ }^{503}$

Retracing the roots of the Christus Patiens we may look even further back in time. While the earliest surviving Christus Patiens representation dates to the twelfth

\footnotetext{
502 Yuri Stoyanov, The Other God: Dualist Religions from Antiquity to the Cathar Heresy, Yale Nota Bene (New Haven: Yale University Press, 2000), 183-84.

${ }^{503}$ Kurt Weitzmann and John Galey, The Monastery of Saint Catherine at Mount Sinai, the Icons (Princeton, N.J: Princeton University Press, 1976), 66-67.
} 
century, there exists textual evidence that crosses with the same iconographic format could also be seen in the capital of the empire as early as the eleventh century. History records a papal legate sent to Constantinople in 1054 critiquing the local Church for depicting "the image of a dead mortal on a cross."

Returning to Italy, the use of Byzantine models became widespread in the early part of the thirteenth century. Anne Derbes reasons that a vast array of avant-garde Byzantine images became readily available to Italian painters at this time following the fall of Constantinople in 1204. That the Franciscans should develop a style of art based on the Byzantine paradigm was a logical outcome. Francis himself visited the Levant in 1219 and had missionaries active in the eastern Mediterranean during his lifetime. The Franciscans' foundation in Constantinople traded in icons with their Italian brothers from 1220. ${ }^{505}$ The minister general of the Franciscan order, Elias of Cortona, also served as the provincial minister of the Holy Land, and as such he traveled extensively through the Byzantine Empire- perhaps even to Mount Sinai. ${ }^{506}$

The monumental crucifixes of the early Franciscans in Italy act as a transmutation of the eastern epistyle renditions of the Great Feasts of the Byzantine Church. While the epistyles present Jesus' Crucifixion as just one part of a series of scriptural events shown at the topmost portion of an iconostasis, the western Church pulls the Crucifixion to the center, enlarges it significantly, and excises the background in order to focus on the corpus on the cross. In the eastern iconography, the central point of the iconostasis was

504 Belting, Likeness and Presence, 270.

505 Derbes, Picturing the Passion, 14-15, 24-25.

${ }^{506}$ Cooper and Robson, The Making of Assisi, 69. 
typically the Deesis - an image of Christ enthroned in majesty flanked by his mother and John the Baptist. Angels and other disciples are often included on either side as well, depending on the size and extravagance of the piece. The panel crucifixes of the West replace the Deesis image with Jesus isolated on the cross, but the intercessory message of Christ and the accompanying saints remains the same as in the Byzantine scheme. ${ }^{507}$ The expanded dimensions, substantial increase of materiality (wood, cloth, paint, oil), and the physical prominence of these crosses afforded the image significant power. In addition, the devotional performance of gazing upon the crucifix constituted a desired participative action by the laity and caused viewers to figuratively and literally raise their attention to the celestial order. ${ }^{508}$

Through my research, it has become clear that examples of the Christus Patiens were created far earlier than Pisano's crucifix. In fact, an extended period occurred in which both Christus Triumphans and Christus Patiens images were synchronous. What then were the reasons behind the varying formats? Han Belting offers an explanation: "The purpose of the icon [of the crucifixion] was to integrate the different doctrines on this central article of faith in such a way that they could be discussed, or their nature could be contemplated, in terms of the image." ${ }^{509}$ The variety of modes used in representing the Crucifixion were based on varying Christological beliefs which struggled to define the nature of Jesus. ${ }^{510}$ Beginning in the thirteenth century, the icon of

\footnotetext{
${ }^{507}$ Belting, Likeness and Presence, 21.

508 Sara Lipton, “The Sweet Lean,” 1193.

${ }^{509}$ Belting, Likeness and Presence, 270.

${ }^{510}$ Belting, Likeness and Presence, 120.
} 
the dead Christ, hanging slumped on the cross, became the dominant form of Crucifixion imagery in Italy. Thomas Herbst credits Pisano's crucifixes in the Porziuncola and San

Francesco with revolutionizing the Christus Patiens form of iconography, stating:

The figure of Christ dominates the crucifix as never before...In previous centuries' representation of the Crucifixion was often simply another means of presenting Christ as the eschatological Lord of the Cosmos. His suffering was hidden and his death forever transcended. The genius of the panel crucifixes was demonstrated by the inverted wisdom of Franciscan poverty in its exaltation of humility and lowliness made it possible for Christ to remain the divine king of Kings without crown or robe, but with a cross for his throne. ${ }^{511}$

So many crosses are extant from Franciscan churches that it is presumed the crosses were ubiquitous in the order's churches. ${ }^{512}$ Francis was devoted to contemplating the Passion and death of Jesus. 513 "In fact," emphasizes Anne Derbes, "the term 'Franciscan Spirituality' has become virtually synonymous with the veneration of Christ's suffering on the cross." ${ }^{514}$ As Belting writes, "The new type attracted viewers' attention when the time was ready for it. St. Francis of Assisi had developed a model for the cult of the Crucified, whom he wanted to resemble even in his sufferings." $" 515$ Just as the founder of the order discovered inspiration through the painted-panel Cross of San Damiano, the Franciscans continued to utilize this form of sacred depiction to influence

${ }^{511}$ Quote is from the version of this article published on Academia.edu. Thomas Herbst, "Franciscan Christology in the Development of the Iconography of the Passion," Academia.Edu, March 2006, 13, 15, https://www.academia.edu/28815731/FRANCISCAN_CHRISTOLOGY_IN_THE_DEVELOPMENT; A variation was published in Thomas Herbst, "Franciscan Christology in the Development of the Iconography of the Passion," The Cord: A Franciscan Spiritual Review 59, no. 3 (September 2009): 308, 311.

\footnotetext{
512 Cooper, "Experiencing Dominican," 51.

${ }^{513}$ Lambert, The Cathars, 171.

${ }^{514}$ Derbes, Picturing the Passion, 17.

${ }^{515}$ Belting, Likeness and Presence, 358.
} 
the faithful and guard against heterodoxy. As we will see, the painted image developed in an effort to promote orthodoxy in specific ways.

\section{The Crucifixes and the Early Franciscan Texts}

For the early Franciscans and the pilgrims who worshipped in their churches, these particular crosses served as a reminder that Francis' ministry was framed by mystical experiences in which the crucifix played a central role: the vocalization by the Cross of San Damiano and the stigmatization of Francis, as discussed in previous sections. We will turn now to consider examples of the monumental crucifixes in conversation with early Franciscan textual sources. The earliest author to follow is Francis himself, of course writing before the artwork made by his order was produced. The literature I will present by the seventh minister general Bonaventure, a Franciscan preacher named Servasanto, and the author known as Pseudo-Bonaventure, was composed nearly contemporaneously to the creation of the crucifixes that will be discussed. Bonaventure's The Tree of Life, from which his meditations on the Passion are drawn, was written between 1257-1267 while he was based in Assisi as the head of the order. This text explores Jesus' humanity from his humble birth, through his obedient childhood, to the years of his public ministry, and finally his suffering at the Crucifixion. ${ }^{516}$ Similar to this first writing but including imaginative apocryphal additions are the selections from Pseudo-Bonaventure's Meditations on the Life of Christ. Authorship and dating of this text are problematic, as it contains evidence for multiple voices and periods, the earliest from 1300-1325 to the latest at 1350 . The oldest extant

${ }^{516}$ Bonaventure and Cousins, Bonaventure: Soul's Journey, 10, 12, 14. 
copy, Paris Bibliotheque Nationale Ms. ital. 115, was created near Pisa around 1350 for a convent of Poor Clares. Despite its complex provenance, the Meditations, which was reproduced in numerous manuscripts during its first century, serves as a textual reflection on the Franciscan crucifixes that the author(s) likely viewed in person and interpreted through their writing. ${ }^{517}$ The sermons of Servasanto provide reflections on the Passion of Jesus in a polemic voice. His instructions given to audiences near Florence reference Jesus' suffering and can be understood as inviting visual contemplation of nearby works of art.

William Cook points out that the majority of surviving crucifixes with Francis depicted at the base are dated after the 1260s. He contends, "it is reasonable to suggest that it is Bonaventure's interpretation of Francis's life and of the stigmata that make this one of the most popular images of Francis of Assisi in the latter part of the duoento." 518 The earliest dipintura crucifixes created by the Franciscans should not be viewed as mere illustrations for the writings of Bonaventure, Servasanto, and Pseudo-Bonaventure, but should rather be considered as their inspiration. After Pisano's 1236 prototype, the oldest cross of our subset hails from the 1250s (see Catalog 3 for the full chronology). It is conceivable that Bonaventure meditated on these very crosses as he composed The Tree

\footnotetext{
517 See recent works by Sarah McNamer, Peter Tóth and Dávid Falvay, and Holly Flora for the current state of this argument. Sarah McNamer, Meditations on the Life of Christ: the Short Italian Text (Notre Dame: University of Notre Dame Press, 2018); Peter Tóth and Dávid Falvay, "New Light on the Date and Authorship of the Meditationes Vitae Christi," Diverse Imaginations of Christ's Life (Turnhout: Brepols, 2015); Holly Flora, The Devout Belief of the Imagination the Paris "Meditationes Vitae Christi" and Female Franciscan Spirituality in Trecento Italy (Turnhout: Brepols, 2009); Pseudo-Bonaventure, Isa Ragusa, and Rosalie Green, Meditations on the Life of Christ; An Illustrated Manuscript of the Fourteenth Century, Princeton Monographs in Art and Archaeology 35 (Princeton, N.J: Princeton University Press, 1961), xxii.

${ }^{518}$ Cook, "Fraternal," 286-88.
} 
of Life. In contrast to the docetist teachings of their Cathar contemporaries which viewed Jesus' body as an illusion, the treatises and meditations of Bonaventure, Servasanto, and Pseudo-Bonaventure focus on the humanity of Christ. In Bonaventure's verses, he explores the theological question of the Incarnation of God. ${ }^{519}$ It was held in Catholic teaching that while creation was considered a great deed performed by God, an even more powerful act was that of God becoming human, which in turn sanctified all of creation. ${ }^{520}$ Amy Neff tells us Bonaventure sought answers for "the perplexing theological problems of why human salvation required God to take human form...[Bonaventure] believed in the value, even the necessity, of seeing Christ, because Christ's visibility demonstrated that the unseen God had fully taken on the form and flesh of a human being." ${ }^{.521}$ This underlying focus necessarily has implications for the development of art by the Franciscan order.

To more closely examine the iconography of the monumental crucifixes, I will narrow my focus to the crosses in the towns of Arezzo, Perugia, Montefalco, and Spello. By focusing on the details of these four examples, I will explore the specific subjects of Incarnational and Eucharistic theology, the emotional tenor of the additional figures portrayed on the crucifixes as models for believers (specifically Mary, John the Apostle, and Francis), and the representation of the physicality of Jesus to express his human nature. Some elements of the artwork that I will explicate repeat from one example to the next; therefore, I will describe selected features of each composition to illustrate the

\footnotetext{
${ }^{519}$ Bonaventure and Cousins, Bonaventure: Soul's Journey, 14.

${ }^{520}$ Steinberg, The Sexuality of Christ, 12.

${ }^{521}$ Neff, "Painting, Devotion, and the Franciscans," 33.
} 
various points of my argument. Through these themes we can witness how the Franciscans subtly, yet clearly, used the images to argue against Cathar beliefs.

\section{Focus on the Doctrine of the Incarnation}

The cross in Arezzo was most likely created for an earlier church and relocated to the new sanctuary built in the fourteenth century (Figure 5.14). William Cook dates this example to 1270 ; however some sources place it as early as 1250 . This range of years aligns almost precisely with the writing of Bonaventure's contemplations (1257-1267). The crucifix in Arezzo was created using egg tempera paint on a cloth base layer stretched on a wooden base. One of the larger examples at $5.75 \times 3.70$ meters, it is the best preserved of the crosses we will consider. Its artist was an anonymous Umbrian painter connected to the Master of Santa Chiara, also known as the Master of Donna Benedetta. ${ }^{52}$ The crucifix is topped with a circular panel, called a clipse, containing an image of Christ as Pantocrator, or All-Powerful. This is a traditional icon of Jesus depicting him as the omnipotent ruler of the universe. He holds a book of scripture and blesses the viewer with his gesture. This image is a reminder that the ruler and judge of humanity, the "Word made Flesh" (from John 1:14), diminished his stature and interacted with creation during his earthly life as Francis recalls in his Letter to the Faithful, "Though He was rich beyond all other things, in this world [Jesus]... willed to choose poverty." ${ }^{523}$ The preacher Servasanto da Faenza, who was active during roughly the same period as Bonaventure, spoke about the Incarnation and Jesus' suffering during the

522 Cook, Images of St. Francis, 29; Artstor, “Crucifixion with Saint Francis,” Artwork, accessed June 29, 2020, http://library.artstor.org/\#/asset/SCALA_ARCHIVES_10310197142.

${ }^{523}$ Francis et al., Francis and Clare, 67. 
Crucifixion, particularly in his sermons for Lent entitled Per proprio sanguinem and Mihi absit gloriari. ${ }^{524}$ In the former, Servasanto laments, "The blood of Christ...had been shed in a most penal effusion if his nature is considered. For his nature was very gentle, tender... the penalty inflicted on it was the most harsh. ${ }^{, 525}$ In his homily De virtutibus, Servasanto tells the congregation that "God's love, greater even than his omnipotence, led him to take flesh and be fixed to a cross for mankind. ${ }^{526}$ In his thesis, Thomas Herbst emphasizes that the Franciscans created a balanced methodology for both their visual and theological expressions of Jesus as God and human. Their dual approach prevented a "banalization which would have occurred if his divinity had been ignored." 527

Beneath the majestic roundel is a rectangular plaque depicting Mary with her hands held in a modified orant position close to her chest. Two archangels flank her, holding staves and gesturing toward Mary who looks up toward the Pantocrator. In Byzantine iconography, this motif is traditionally given the title Our Lady of the Angels. The star positioned beneath this plaque mirrors the three stars which often appear on her cloak in icons of Mary as a reminder of her virginity. The star could also allude to Jesus' birth in Bethlehem which scripture states was marked with an astronomic event. Francis focuses on the doctrine of the Incarnation in much of his writing concerning Mary, stating: "The blessed Virgin is so honored, as is right, since she carried Him in [her] most

${ }^{524}$ Dansereau, Servasanto Da Faenza, 181.

${ }^{525}$ Dansereau, Servasanto Da Faenza, 220.

${ }^{526}$ Dansereau, Servasanto Da Faenza, 181.

${ }^{527}$ Herbst, "Franciscan Christology," 12. 
holy womb. ${ }^{" 528}$ Francis goes on to promote the belief in the human nature of Jesus, “...in the womb of the holy and glorious Virgin Mary, from whose womb He received the flesh of our humanity and frailty. $" 529$

The Incarnation of Jesus was the Church doctrine that the Cathars most strongly disavowed. The Perfectus Pierre Autier taught that "Christ was a pure spirit, not in reality or even appearance born of Mary, who was not a woman at all: she was simply the will to do good." ${ }^{530}$ Guilhem Bélibaste differed from Pierre Autier in his stance on Marysaying that she was an actual woman who was "only spiritually the mother of Christ." $\mathrm{He}$ taught that Jesus took a visible body from Mary, who was "sometimes interpreted as the Cathar Church and sometimes as an actual figure, albeit without a true human body." ${ }^{231}$ The Cathars at Montaillou believed that "Christ could not have existed in earthly flesh, for incarnation would automatically have Satanized him." ${ }^{532}$ According to Cathar teaching, Christ was immune from human travails such as hunger, thirst, the effect of temperature, or physical pain. Nor could he suffer death, as he was already a free spirit. ${ }^{533}$

Looking at the Arezzo corpus, the face of Christ appears swollen with a prominent nose, drooping closed eyes, and a full beard. His long hair is parted in the middle and the crown of thorns fills the narrow forehead. The words Rex Glorie (King of

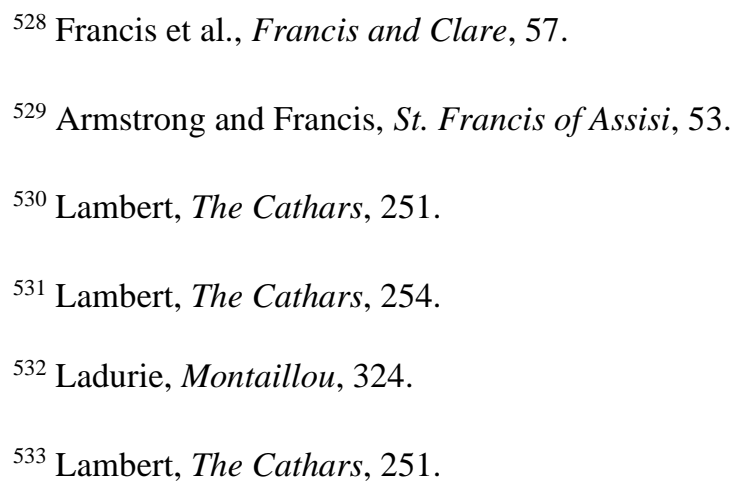


Glory) are written above Jesus' outstretched arms. These terminate in open hands pierced with nails. The blood falling from the palms swirls as if suspended in clear water. The bones of the sternum and ribs are stylized as the body twists to the viewer's left. Jesus' side wound is barely bleeding. The hips, pelvis, and upper legs are covered with a transparent cream-colored cloth thinly striped in red and black and fringed in gold. The outline of Jesus' thighs is clearly visible through the cloth, which is knotted below the naval in a position suggestive of genitalia. In his fourteenth-century meditation on the crucifixion, Pseudo-Bonaventure exhorts his reader to "Pay diligent attention to this and consider His stature in every part. And to make yourself more deeply compassionate and nourish yourself at the same time, turn your eyes away from His divinity for a little while and consider Him purely as a man." 534

Taking this instruction many years later, Leo Steinberg convincingly establishes in The Sexuality of Christ in Renaissance Art and in Modern Oblivion, that the physical, even sexual, nature of Christ depicted in art serves the purpose of emphasizing Jesus' humanity. Steinberg points to Bonaventure's writing as evidence:

When man sinned...he fell headlong into weakness, ignorance, and malice...He could no longer imitate divine power, behold divine light, or love divine goodness. The most perfect way for man to be raised out of his misery was for the first Principle to come down to man's level, offering Himself to him as an accessible object of knowledge, love, and imitation. Man, carnal, animal, and sensual, could not know, love, or imitate anything that was not both proportionate and similar to himself. So, in order to raise man out of his state, the Word was made flesh; that He might be known and loved and imitated by man who was flesh... ${ }^{535}$

${ }^{534}$ Pseudo-Bonaventure, Ragusa, and Green, Meditations, 330.

535 Bonaventure, "St. Bonaventure: The Breviloquium," IV, 3, accessed April 8, 2016, http://agnuz.info/app/webroot/library/7/13/; Bonaventure quoted in Steinberg, The Sexuality of Christ, 121. 
In all save two of the ten crucifixes from our subgroup, a prominent and intricately tied knot stands out below Jesus' naval (See Catalog 3). Steinberg briefly asserts these knots could serve as an allusion to an erect phallus - a reference to Jesus' humanity. Steinberg does not consider the crosses of the earliest Franciscan commission, briefly mentioning only those by Giotto (c. 1267 - 1337) and Duccio (c. 1255-1319) for comparanda and attributing to them (incorrectly) the introduction of the translucent perizoma. Yet his theory concerning the infant and child Jesus' phallus as a reference to his human state can be extrapolated to the adult male Jesus' physicality. The noted Jesuit scholar and Renaissance historian John W. O’Malley responded positively to Steinberg's similarly radical hypotheses. He admits that the representation of Jesus' phallus as a symbol of his Incarnation is acceptable from a theological standpoint. ${ }^{536}$

Other explanations have been offered to counter Steinberg's hypothesis, most notably by Caroline Walker Bynum. While Walker Bynum does agree with Steinberg that medieval symbolism is multivalent and based on theological beliefs and devotional practices, she feels the art should be viewed independently of the erotically charged lens through which modern viewers judge medieval representations of the body. ${ }^{537}$ Bynum believes that Steinberg reads too much into medieval and Renaissance theology in order to come to his conclusion that depictions of Jesus' genitalia serve as a symbol for his humanity. Bynum argues that Jesus' phallus was understood in medieval times not as a

${ }^{536}$ Although Steinberg deals mainly with Renaissance images, his use of Bonaventure's text justifies an extrapolation to earlier depictions of the crucifixion. John O'Malley, SJ provided the public response to Steinberg's initial presentation of his ideas at Columbia University in 1981, Steinberg, The Sexuality of Christ, 136, 201, 216.

${ }^{537}$ Unless noted, information in this section is taken from Caroline Walker Bynum, "The Body of Christ in the Later Middle Ages: A Reply to Leo Steinberg," Renaissance Quarterly / Publ. by the Renaissance Society of America., 1986, 403-13, 438. 
sexual organ, but rather as the locus of shedding the first blood of salvation that occurred during Jesus' ritual circumcision. Bleeding, in the sacrificial context, represented purging and atonement. The focus she finds in the texts is that "humanness" is recognized in a shared capacity for suffering, rather than sexual temptation. Bynum criticizes Steinberg's lack of medieval and Renaissance writings which discuss Jesus' genitalia as an organ for erotic or reproductive activity. In her view, medieval and Renaissance texts reveal an emphasis on redemption as being brought about by the "humanation" or "enfleshing" of God in all parts of the body, not just the genitals. Bynum concludes her analysis saying, "there is little textual support for Steinberg's argument that the artistic focus of Renaissance painters on Christ's penis was a theological statement about sexuality." 538 In this regard, I believe Walker Bynum's reading of Steinberg's term sexuality is limited to the procreative or erotic action. Rather, I propose that Steinberg considers sexuality to be an inherently human attribute of creative potentiality, regardless of the sex act. In such a reading, the symbolism of the knotted loincloth certainly does support an emphasis on the Incarnation.

Below the thighs, Jesus' legs are depicted simply with ovals at the kneecaps and calf muscles delineated on either side. The legs are pressed together at the heel with his feet pointing away from each other at a gentle angle. They are nailed to the cross separately. Pseudo-Bonaventure, in more florid text than the true Bonaventure, emphasizes the agony the man Jesus would have experienced in a meditation which juxtaposes Christ's dual natures. When Jesus' divinity is considered, it is in relation to his humanity:

538 Walker Bynum, "The Body of Christ," 437. 
Look at Him diligently, therefore, and be moved to pity and compassion...Next return to His divinity and consider the immense, eternal, incomprehensible, and imperial Majesty incarnate, humbly bowing down, bending to the ground... ${ }^{539}$

The cross in Arezzo is decorated in the side terminals with half-length portraits of Mary and John the Apostle, painted at one third scale compared to Christ. John, on Jesus' left, gestures with his open right hand toward Jesus. His left hand has deteriorated enough that its position is unreadable. Unique to the Arezzo cross, John faces away from Jesus, looking down at the viewer, perhaps in reference to the Gospel writer's impetus to relay the Paschal mystery to the congregation gathered below.

Mary stands at Jesus' right hand with her head bowed, eyes looking toward the crucified Christ. Her left hand reaches to her face as if wiping tears, while her right hand gestures toward her son. Her red cloak is gathered just below her chest with a slightly bulbous protrusion, perhaps indicating her miraculous pregnancy. Bonaventure's reflection on Mary focuses not only on her grief as a mother, but also on the role she played as the provider for the flesh of Christ's humanity:

You were present at all these events, standing close by and participating in them in every way. This blessed and most holy flesh - which you so chastely conceived, so sweetly nourished and fed with your milk, which you so often held on your lap, and kissed with your lips-you actually gazed upon with your bodily eyes now torn by the blows of the scourges, now pierced by the points of the thorns, now struck by the reed, now beaten by hands and fists, now pierced by nails and fixed to the wood of the cross...now oppressed by sadness and sorrow partly because of his most sensitive response to bodily pain. ${ }^{540}$

\footnotetext{
${ }^{539}$ Pseudo-Bonaventure, Ragusa, and Green, Meditations, 331.

${ }^{540}$ Bonaventure and Cousins, Bonaventure: Soul's Journey, 152.
} 
Francis of Assisi stands below the cross. In Arezzo, he is depicted larger in relation to the figure of Christ than the other images of the saint considered in this subset of crucifixes. Francis holds Jesus' right foot in both his stigmatized hands and tenderly presses his lips against the nail. The right toes of Jesus' foot point to the side wound of Francis' stigmata, which is exposed through an opening in his robe. The blood drips over Francis' hands and flows behind the saint, with blood from Christ's other foot pouring onto Francis' left foot, which is also clearly wounded with the stigmata. The placement of Francis at the feet reflects the hierarchical arrangement of the body in medieval belief. The words of the early church historian Eusebius (c. 263-339) expressed the hypostatic union to reveal this understanding: "The nature of Christ is twofold; it is like the head of the body in that He is recognized as God, and comparable to the feet in that for our salvation He put on manhood as frail as our own." 541 The head was considered godlier while the feet touched the materiality of earth. ${ }^{542}$ Francis' embrace of Jesus' feet is thus not only a recognition of the saint's poverty and humility, but it is also an expression of Francis' devotion to Jesus' human nature.

According to Herbst, early Franciscan crosses merged theology and art through their representation of "Christ's humanity as a mirror of his divinity. This was biblical, in the sense that humanity was acknowledged to have been created in the image of God, but it was also radical since, in the Passion, Christ participated in the worst aspects of the human condition." ${ }^{543}$ Both the divine and human persons were somehow to be expressed

\footnotetext{
${ }^{541}$ Eusebius' History of the Church, I, 2, quoted in Steinberg, The Sexuality of Christ, 150.

${ }^{542}$ Steinberg, The Sexuality of Christ, 149.

${ }^{543}$ Herbst, "Franciscan Christology," 16.
} 
through the art. Leo Steinberg recognizes the evolving illustration of Jesus' duality in art. He expounds, “...in celebrating the union of God and man in the Incarnation, Western artists began displacing the emphasis, shifting from the majesty of unapproachable godhead to a being known, loved, and imitable." 544 Steinberg identifies the development in which art begins to focus on the human aspects of Jesus, but he does not offer any reasons for the transition. As the early Franciscans dealt with this very question of Jesus' dual nature, it is likely that they enacted a move to artwork which emphasized the humanization of Jesus in response to the Cathars' strict belief in a single-natured Principle. The Cathars' claim that Jesus was only spiritual, presenting merely an illusion of a body, was an unacceptable challenge to orthodoxy that the early brotherhood felt had to be countered in every possible way.

\section{Eucharistic Emphasis}

Complex deliberations concerning the meaning and process of the Eucharist took place during the twelfth and thirteenth centuries. The Fourth Lateran Council declared the doctrine of the Real Presence in 1215 which set forth the Church's belief in the physical presence of Jesus on the altar, transformed from the bread and wine. ${ }^{545}$ At the same council, the Church instituted the requirement that each believer should participate in the Eucharist at least once per year. Increased worship of the consecrated bread echoed prior reverence and rituals related to saintly relics but with even stronger devotion. ${ }^{546}$ The

544 Steinberg, The Sexuality of Christ, 14.

545 Derbes, Picturing the Passion, 17-18. Canon One, "Fourth Lateran Council: Internet Medieval Sourcebook. Hanover College,” accessed March 11, 2016, http://history.hanover.edu/courses/excerpts/344lat.html.

${ }^{546}$ Lansing, Power and Purity, 162. 
ultimate goal of the Cathars was to discredit and abolish the Mass because of its crucial standing in Catholic devotional practice. ${ }^{547}$ Cathars took a rationalist approach to the sacrament of the Eucharist. In his examination of Cathar history, Malcolm Lambert explains how Pierre Autier "used the ancient mot [joke] about Christ's body needing to be as big as a mountain to feed the priests." Another critique lay in the question of Jesus' body being eaten, digested, and excreted into the latrine. Autier also questioned his attentive crowds about the possibility of mice consuming the Body of Christ. Lambert says Jacques Autier, Pierre's son or brother, claimed "there was nothing worthwhile in the mass but the gospel and the paternoster; chants and the rest were a deceit of the priest." 548

In contrast to the Cathars, Francis believed the Eucharist flowed from and continued the Incarnation. ${ }^{549}$ Reflecting on the celebration of the Eucharist as mirroring Jesus' human life, Francis wrote,

As He appeared to the holy apostles in true flesh, so now He reveals Himself to us in the sacred bread. And as they saw only His flesh by means of their bodily sight, yet believed Him to be God as they contemplated Him with the eyes of faith, so, as we see bread and wine with [our] bodily eyes, we too are to see and firmly believe them to be His most holy Body and Blood living and true. ${ }^{550}$

Francis writes about reverence for the consecrated bread and wine, urging that the Body and Blood be reserved in a clean and protected space and treated

${ }^{547}$ Lambert, The Cathars, 248.

${ }^{548}$ The Cathar version of the Pater Noster refers to "supersubstantial bread" removing the temptation to consume material food. Lambert, The Cathars, 248.

${ }^{549}$ Armstrong and Francis, St. Francis of Assisi, 46.

${ }^{550}$ Francis et al., Francis and Clare, 27. 
respectfully. ${ }^{551} \mathrm{He}$ was fastidious about the Eucharist and the material goods

pertaining to it. In a letter to the custodians of the brotherhood he requested they:

...beg the clergy to revere above everything else the most holy Body and Blood of our Lord Jesus Christ and His holy written words which consecrate [His] Body. The chalices, corporals, appointments of the altar, and everything which pertains to the sacrifice must be of precious material.

Francis further explains that his friars should express the necessity for the Eucharist in their preaching. He says:

And in every sermon... [tell them] that no one can be saved unless he receive the Body and Blood of the Lord. And when It is sacrificed upon the altar by the priest and carried to any place, let all the people, on bended knee, praise, glorify, and honor the Lord God living and true. ${ }^{552}$

In 1264, most likely in response to the continued popularity of Cathar dualism, Pope Urban IV published the papal bull Transiturus in the Umbrian town of Orvieto. ${ }^{553}$ This letter announced the Feast of Corpus Christi, a new holy day that unambiguously celebrated the physical body of Jesus. The crucifix in nearby Arezzo was painted within about a decade of this proclamation. This key focus on the true presence of Jesus in the Eucharist encouraged the early Franciscans not only to continue the practice of placing a cross prominently in their churches but to amplify its presence (Figure 5.15). Ritually the doctrine of the Real Presence was reinforced by the elevation of the host during the Eucharistic prayer, an addition to the Roman missal promoted by the Franciscans. Anne Derbes points out that the Eucharistic rite was framed more and more by elaborate

${ }^{551}$ Armstrong and Francis, St. Francis of Assisi, 45-46.

${ }^{552}$ Francis et al., Francis and Clare, 53.

${ }^{553}$ Lansing, Power and Purity, 13. 
altarpieces, with the monumental cross resting at the head of this structure. ${ }^{554}$ At the lower section of the cross in Arezzo (Figure 5.16), as in other crosses in this study, Christ's blood is painted as flowing down the cross and onto the supporting rocks, a symbol of the earth. It would not be a far leap in the minds of the congregation gathered for Mass to imagine the blood continuing its descent onto the altar, joining in the sacrifice of the Mass occurring below the image. Donal Cooper describes the setting:

In larger churches, monumental crosses...were invariably aligned with high altars on the main axis of the nave. In most cases they were mounted high above the floor level of the church, thereby transcending choir screens and other internal divisions, while their generous dimensions rendered them legible down the length of the nave...For the laity beyond the screen they would have towered over the high altar, creating a powerful visual juxtaposition between the representation of Christ on the cross and His instituted presence on the mensa below. ${ }^{555}$

The monumental cross was a focal point for the worshipper, highlighting the altar as the sacred space where Jesus' sacrifice was re-presented during the liturgy ${ }^{556}$ The image of the cross served as a replacement for the presence of Jesus in the consecrated bread which was mostly concealed from the congregation's view except during the elevation. ${ }^{557}$

The cross in Arezzo has a beveled frame painted in gold. The background of the cross is black while the tabellone is decorated with alternating black and red cruciform flowers, resembling the dogwood blossom - a traditional symbol of the Crucifixion. From a distance this design appears to be diamond shaped. In an article discussing the

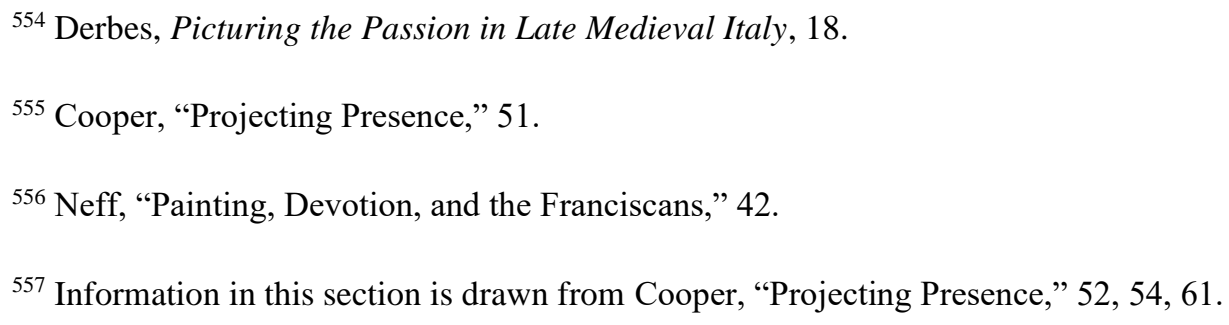


crucifix in the town of Montefalco, Donal Cooper explains that this decorative feature of the geometric apron, which long mystified art historians, mirrors the textiles used for altar dressing beneath the cross. Cooper references illustrations of altar cloths that were popular in thirteenth-century Italy, usually made of silk and woven into Islamic and Spanish designs. This painted altar cloth further emphasized the sacrifice of Jesus' broken body on the sacrificial table of the cross, a visual axis mundi linking the Real Presence on the high altar and the heavenly Christ.

Herbert Kessler's work on Christian representations of the Jewish temple curtain may also elucidate the meaning of these floral- and geometrically-painted tabellone, repeated on every cross in this study. Kessler presents an eleventh-century manuscript from Mount Sinai that features varied diamond, checkered, and flower patterns for the temple curtain in Jerusalem (Christian Topography, Cod. 1186, 79r. Figure 5.17). Kessler acknowledges, "The Epistle to the Hebrews likens Christ to the tabernacle, and also to the temple curtain which is the 'entrance way'; Hebrews 10.19-20 declaims that the 'blood of Jesus makes us free to enter boldly in the sanctuary by the new, living way he has opened for us through the curtain, the way of his flesh." ${ }^{558}$ In describing the death of Jesus in The Tree of Life, Bonaventure quotes the gospel of Matthew: "Then the veil of the temple was torn from top to bottom and the earth quaked and the rocks were rent and the tombs were opened (Matthew 27: 51-52). ${ }^{559}$ This same allusion to the temple curtain, the entrance to the Holy of Holies, was continued on the Franciscan crosses in grand form (Figure 5.18, See Catalog 3 for complete list of the crosses' apron designs). It would have

\footnotetext{
${ }^{558}$ Kessler, Spiritual Seeing, 58.

${ }^{559}$ Bonaventure and Cousins, Bonaventure: Soul's Journey, 153.
} 
reminded believers that their future entrance into Heaven could only be achieved through participating in the sacrifice of Jesus, and reception of the consecrated Host during the Mass. In his expanded letter to the faithful, Francis points out this relationship between the Eucharist and the cross, finding it remarkable that Jesus should "through His own blood, offer Himself as a sacrifice and oblation on the altar of the cross." ${ }^{560}$ Francis' exhortation to orthodox belief and practice would have spoken directly against the Cathars' vehement opposition to both the cross and the Eucharist.

\section{Companions at the Cross}

Another approach the early Franciscans used to underscore the humanity of Christ in their crucifixes was by focusing on the companions of Jesus who stood by him at the cross. The Cathars insisted the Crucifixion was a simulation - that Jesus was unharmed by the tortures of the Passion. In contrast, the Franciscans promoted the companions of Christ as giving witness to (and sharing in) Jesus' agony, offering a symbol of verification for the historical events they believed took place.

The earlier style of historiated Christus Triumphans crucifixes illustrated, in the tabellone, a small crowd of people attending Jesus' Passion as seen on the Cross of San Damiano. In The Tree of Life, Bonaventure reduces these participants to only Mary and John the Apostle. ${ }^{561}$ The early Franciscan crucifixes show a similar focus. They displace Mary and John, traditionally believed to be the follower described as "beloved" in

${ }^{560}$ Francis et al., Francis and Clare, 68.

${ }^{561}$ Bonaventure indicates the presence of John through a brief allusion when Jesus says to his Mother: "Woman, behold your son." Bonaventure and Cousins, Bonaventure: Soul's Journey, 153. 
Christian scripture, to the arms of the cross rather than closer in the apron, thereby increasing the viewer's attention on the corpus at the center. ${ }^{562}$

At $3.25 \times 4.86$ meters, the crucifix housed in the Perugia Galleria Nationale dell'Umbria is the second largest of the extant crosses which depict Francis at the base, after the Arezzo example (Figure 5.19). It was originally created for the Church of San Francesco al Prato in Perugia. Construction of the church began 1251. Over the centuries the building suffered damage due to earthquakes and landslides and was demolished and rebuilt at least twice. The artist known as the St. Francis Master dated the cross in 1272, noting on the inscription below the feet of Jesus that it was executed in the reign of Pope Gregory X (r. 1271-1276). This dating would again place the painting of the Perugian cross in close proximity to the written works of Bonaventure and Servasanto and prior to Pseudo-Bonaventure.

The top of the cross is similar to that in Arezzo in regard to the Pantocrator and Our Lady of the Angels panels, but the crucifix in Perugia deviates significantly for the lower terminals. While the focus in Byzantine altar imagery was on the Deesis at the center of the epistyle, the monumental crosses of the Franciscans shifted the liturgical attention to the Crucifixion. The panel crucifixes of the Franciscans limit the contemporary bystanders of the scene to Mary and John the Apostle. ${ }^{563}$

Mary remained at Jesus' right hand. John the Apostle replaced John the Baptist from the Deesis. The raw emotion expressed by the bystanders is an important development. No longer standing rigid and stoic, their grief is even more pronounced

\footnotetext{
562 Derbes, Picturing the Passion, 20-21.

${ }^{563}$ Belting, Likeness and Presence, 358.
} 
than had been depicted in the examples from Serbia and Mount Sinai. The crucifix of Perugia presents Mary and John as full-length figures, painted at one quarter scale compared to Jesus. Both turn toward the twisted and bleeding figure of Christ in the center. The disciple holds his head bowed deeply to his upraised right hand. He lifts his left hand over his heart in a gentle clasp. John's eyes appear downcast, as if gazing at the nail wound in Jesus' hand.

On the viewer's left Mary's head bows deeply, her gaze locked on her son's face.

The anguish of the woman is described in detail by Pseudo-Bonaventure:

All this is done and said in the presence of His most sorrowful mother, whose great compassion adds to the Passion of her Son, and conversely. She hung with her Son on the cross and wished to die with Him rather than live any longer. ${ }^{564}$

The author relays that after Jesus had expired, the soldiers returned to verify the prisoners' deaths, or hasten it by breaking their legs. Both Mary and John entreat the soldiers to leave the body in peace. Ignoring their request, a soldier "opened a great wound in the right side of the Lord Jesus; and blood and water came forth." 565 The side wound is depicted on the cross of Perugia as a spurting cleft on the right ribcage of Jesus, bisected by a long crack which reveals the division between the cross' wooden panels. The blood interplays with the alternating red and blue / burgundy and black blossoms that form the geometric background for this cross.

The sorrowful visages of Jesus' mother and disciple serve as a powerful witness to affliction - painful to watch, yet both they and the thirteenth-century congregants

${ }^{564}$ Pseudo-Bonaventure, Ragusa, and Green, Meditations, 335.

${ }^{565}$ Pseudo-Bonaventure, Ragusa, and Green, Meditations, 339. 
looking at the scene were helpless against the violence and suffering. ${ }^{566}$ In her article, “Stigmata and Sense Memory: St Francis and the Affective Image," Jill Bennett discusses the similar crucifix at Montefalco as eliciting from the audience a compassionate reaction, a "sympathetic pathos," to the represented anguish (Figure 5.20). ${ }^{567}$ She says that this is achieved by evoking an emotional reaction in the viewer, a sense-memory of pain or violence. Bennett contends the viewer is moved or even assaulted by the image and becomes able to enter into the scene through an "empathetic imitation" of the pain witnessed therein. ${ }^{568}$ The believer who attended Mass below these crucifixes could gaze at the suffering of Jesus and join with Mary and John in their participative, eviscerating sorrow. This example of affective devotion continued through the thirteenth-century Franciscans' spirituality, expressed in their writings, sermons, and artwork.

Also painted on the crosses as a witness to the Crucifixion is Francis of Assisi himself. The image of the cross shaped the experience of the saint and the early Franciscan order, beginning with Francis' conversion at the foot of a crucifix that spoke to him and ending with the saint's miraculous stigmatization near the end of his life. The representation of the poverello at Jesus' feet can be understood to serve dual symbolic roles. First, Francis can be perceived as an alter Christus: an iteration of Jesus active in the contemporary medieval world. ${ }^{569}$ In the artwork of the Franciscans, the wounds of

566 Jill Bennett, "Stigmata and Sense Memory: St Francis and the Affective Image," Art History 24 (2001): 9.

\footnotetext{
${ }^{567}$ Herbst, "Franciscan Christology," 13.

${ }^{568}$ Bennett, "Stigmata and Sense Memory," 5, 10.

${ }^{569}$ Kennedy et al., Sanctity Pictured, 19.
} 
Francis evolved to a more pronounced duplication of Christ's wounds, and in this form he embodied a virtual crucifix. Second, Francis was seen as an exemplar for Christians as he was understood to spiritually witness Christ's Passion as the most ardent adorer of Jesus' sacrificial and redemptive body and blood. In his sermon De virtutibus, the preacher Servasanto commented on how Francis endured "patient suffering" and thus became more alike to Christ on the cross through his stigmata. ${ }^{570}$

Painted at one-fifth scale to Jesus, the kneeling image of Francis in the Perugia cross would have been visible to the congregation even when it was raised to the tramezzo of the church in Perugia (Figure 5.21). Shown against a background of brown flowers, Francis gestures with his left hand toward the wounds in Jesus' feet. Two streams of blood cascade from the nail punctures, pooling onto the inscription at the base of the cross. Francis' right hand is raised in a teaching gesture addressing the congregation below. In this pose, he mirrors the docent position of the Pantocrator at the head of the cross. Viewers could witness in Francis' adoration at the foot of the cross the love, self-abnegation, and dedication necessary to join in the redemption provided by Christ. ${ }^{571}$ Hans Belting describes the spiritual understanding and practice that were employed during this era. By meditating on a sacred image, medieval lay people could imitate the life of a saint. Because the image incorporated the same motifs that the saint had utilized or that had inspired the holy life, the laity were able to join in the saint's

${ }^{570}$ Dansereau, Servasanto Da Faenza, 215.

${ }^{571}$ Neff, "Painting, Devotion, and the Franciscans," 39. 
sphere of influence, overcoming the distractions of secular life and mirroring the saint's piety. ${ }^{572}$ The devotee became one of the companions at the Crucifixion.

Discussing the cross in Montefalco again, Jill Bennett differentiates the biblicalnarrative space occupied by Mary and John the Apostle with that of Francis. She holds that the image of Francis serves as a negotiator of the liminal space between the plane of the viewer and the plane of Jesus. In the crucifix at Perugia, Francis gazes upon Jesus' right foot. So close to touching, the dark outline of Francis' hand merges with and impacts the outline of Jesus' nailed foot. ${ }^{573}$ Bennett observes, "Francis is not here engaged in a purely visual interaction, but in a devotional response mediated through the sense of touch." ${ }^{\text {574 }}$ It is a mystical state believed to be achievable by those who interacted with the cross, becoming a participant in the scene along with Francis, Mary, and John. Bennett argues,

...the structure of the memory process is such that one receives information through the senses which is then transmuted into a visual image, the implication is that the visual retains the capacity to evoke sensation. As such, devotional images do not simply represent sensation, but function to regenerate or actively to produce sensation in the viewer, so that the kind of tactile convergence depicted in the Montefalco crucifix is, in effect, actualized through the process of viewing as the spectator finds herself 'touched' by the image... [The viewer] seeks to become one with the image, or at least to be absorbed by it... ${ }^{575}$

Servasanto held a similar belief. He implores his listeners to reflect visually on the pain of Jesus, giving full attention and utmost compassion to the devotion of Christ on the

\footnotetext{
${ }^{572}$ Belting, Likeness and Presence, 362.

${ }^{573}$ Bennett, "Stigmata and Sense Memory," 2.

${ }^{574}$ Bennett, "Stigmata and Sense Memory," 7.

575 Bennett, "Stigmata and Sense Memory," 8-9.
} 
cross. Servasanto encourages, "For you will more lightly bear your own sufferings if you see the bitterness of the Lord's passion." ${ }^{\text {576 }}$ Imitation was considered a necessary piece to experiencing compassion. ${ }^{577}$

In her article, "The Sweet Lean of His Head,” Sara Lipton describes a method of observation that was considered spiritually effective by the medieval viewer. It involved "the extended process of looking encompassing the passage of time and thereby incorporating the faculty of memory." ${ }^{, 578}$ In her analysis of a text by Rupert of Deutz, in which the twelfth-century Flemish Benedictine was able to embrace the image of the crucified Christ, Lipton makes it clear that sustained looking at the crucifix of Christ is only half the equation necessary for a transcendental experience. Once a believer spends time in adoration, it was believed to be contingent on the Divine to draw near to the believer in the circumstance of a mystic vision. ${ }^{579}$ One can draw a parallel between Rupert of Deutz's embrace of the corpus and Francis' interaction with the body of Christ both at San Damiano and in the stigmatization. The viewing subject exists in a state of potentiality. If one meditates on the image of the cross, it was believed, they have the capacity to be transformed, as Francis was. When the friars introduced these images, they shared with the believing public a way to become

${ }^{576}$ Servasanto in Surrexit Saulus, quoted in Dansereau, Servasanto Da Faenza, 220.

${ }^{577}$ Dansereau, Servasanto Da Faenza, 224.

${ }^{578}$ Lipton, “The Sweet Lean,” 1176.

${ }^{579}$ Rupert of Deutz's commentary on Matthew (De gloria et honore Filii hominis), written in 1127. Lipton, "The Sweet Lean," 1178. 
both Francis-like and Christ-like. ${ }^{580}$ In addition, as the Benedictine monk was writing in response to the negative reaction of a Jewish man to the crucifix (which the man considered a repulsive idol), we can find a connection between Rupert's impetus to describe his experience and that of the early Franciscans who were also reacting to non-believers in the context of a Cathar region. ${ }^{581}$ Thus the gaze of the congregation upon the tortured body of Christ was thought to serve as a route to a transcendental event sanctioned and encouraged by orthodoxy.

\section{Tortured Physicality}

During the thirteenth century, craftsmen began to inspect natural forms in close detail in order to portray bodies and their environment with greater accuracy. Yet this naturalism was tempered by the contemporary conception of the human body as a stylized structure that followed a pattern of divinely inspired geometry. ${ }^{582}$ Returning to Cennino Cennini's artist's handbook, he explains the correct measurements of a human figure. These instructions had been rigorously adhered to from Greco-Roman tradition and were well-established by the period of the early Franciscans. ${ }^{583}$ Using a compass, the layout of the figure is determined by a series of circles and arcs upon a grid. The resulting human form is described as the homo quadratus, in which "all measurements of the human body and all movements of its limbs may be enclosed in the two most important

${ }^{580}$ Bennett, "Stigmata and Sense Memory," 6.

${ }^{581}$ Lipton, “The Sweet Lean,” 1181.

${ }^{582}$ Michael Camille, Gothic Art: Glorious Visions (New York: Harry N. Abrams, 1996), 133-34.

${ }^{583}$ Cennini and Thompson, The Craftsman's Handbook, 48-49. The original source for the homo quadratus measurements stems from Vitruvius' De Architectura. Book Nine. 
and primitive geometrical forms, the circle and the square. ${ }^{n 84}$ These measurements served the artists of the medieval period as a tool to faithfully represent Jesus' body as both a physical construction and an expression of divine perfection. ${ }^{585}$ Yet the illustration of the body as an ordered concept did not purge it of human messiness. If anything, the depiction of Jesus' body was shown with greater goriness as the thirteenth century progressed.

In their texts, theologians could neglect the details of Christ's physicality. It was sufficient to explain that Jesus took human form and then he served, suffered, and died. But artists worked directly with the contours and colors of the body to illustrate both Jesus' life and death. ${ }^{586}$ Sculptors moulded the muscular legs of an itinerant preacher and wounded side of the corpse. The painter shadowed the weary eyes and blood dripping from pierced forehead. It was the artist who delivered theology to the sight of both devotees and doubters, and through the image taught them what to believe. The early Franciscan theologians, writing in the shadow of crucifixes such as Pisano's, innovatively described the suffering they saw in paint and wood and encouraged meditation on the physical reality. After the texts of early Franciscans were widely and rapidly disseminated, such as those by Bonaventure and Servasanto da Faenza, their written words reciprocated grisly details of the Passion to subsequent crucifixes. This can be observed in the crucifix of Spello which was produced at the end of the century, c. 1290

${ }^{584}$ Baldini and Casazza, Crucifix by Cimabue, 18.

585 Baldini and Casazza, 13-19. Baldini provides illustrations on page 65 of The Crucifix by Cimabue.

${ }^{586}$ Steinberg, The Sexuality of Christ, 16-17. 
(Figure 5.22). This crucifix, like that in Montefalco, is possibly by the Expressionist Master of Santa Chiara (who may be have been Palmerino di Guido). ${ }^{587}$

The crucifix in the Church of Sant' Andrea in Spello probably had its origin in a Tuscan church but was moved to Umbria by 1400. It has been severely cut down, with the terminals possibly deteriorated beyond retention or, more likely, harvested and sold as separate icon panels. ${ }^{588}$ The predominant color of the remaining background is a grayish blue. The narrow vertical rectangles remaining of the apron reveal a burgundy and gold floral pattern with a diamond geometry.

Like all but one cross in this study (that in Arezzo, Figure 5.14), the crucifix in Spello does not depict Jesus wearing a crown of thorns. Despite the Gospel account, Bonaventure only briefly mentions that Jesus was tortured in such a way and gives no further description of Jesus' face throughout the Passion. ${ }^{589}$ On the painted crucifix, Jesus' head is tipped forward onto his chest. His stylized ginger hair is capped by a halo of gold. The typical tripartite decoration of the halo has been reduced to only two arms in this example - the third seeming to be lost behind the drooping head. The beard blends into the shadow on the chest. Having tasted the gall and vinegar, Jesus' mouth rests in a neutral position with the lips slightly open.

In his writing, Bonaventure claims that the bodily suffering of Jesus was required for the salvation of humanity, expressing strong disagreement with the docetist position

${ }^{587}$ Cook, Images of St. Francis of Assisi, 216.

${ }^{588}$ No evidence for the terminal panels (presumably images of Mary and John the Apostle) was discovered in the research for this study.

${ }^{589}$ Bonaventure and Cousins, Bonaventure: Soul's Journey, 149. 
of the Cathars. ${ }^{590}$ The theologian's words are echoed in the crucifix of Spello with the aim to elicit emotion from both the reader and the viewer. ${ }^{591}$ Each of Bonaventure's meditations appeals directly to the senses. Asking the believer to participate in the action of the scene, he utilizes graphic descriptions to produce an emotional impact. ${ }^{592}$ Bonaventure's description of the crucifixion is straightforward yet vivid:

Bearing his cross for himself, he was led forth to the place of Calvary. There he was stripped completely and covered only with a cheap loincloth. Thrown roughly upon the wood of the cross, spread out, pulled forward and stretched back and forth like a hide, he was pierced by pointed nails, fixed to the cross by his sacred hands and feet and most roughly torn with wounds. ${ }^{593}$

The distinguishing feature of the corpus at Spello is its sophisticated modeling (Figure 5.22). Each muscular curve is delineated by shadow. The ligaments of Jesus' shoulders protrude while his hands curl into shaded palms. The loincloth is not knotted here but rather is tissue thin, revealing the contours of Jesus' legs and groin.

In this crucifix, the blood, or as Servasanto calls it, "most pious effusion," exits Jesus' wounds with lurid brightness, spurting from the upper ribs before flowing down the length of his torso. The preacher shares Bonaventure's focus on Jesus' redemptive act, continuing "he did not suffer for his own fault, but that of another." 594 Francis" mirroring of Jesus' stigmata and the focus paid to it by the early brothers, propagated the

${ }^{590}$ Dansereau, Servasanto Da Faenza, 214.

${ }^{591}$ Ignatius Brady, O.F.M. in the Preface to Bonaventure and Cousins, Bonaventure: The Soul's Journey into God; The Tree of Life; The Life of St. Francis, xiv.

592 Bonaventure and Cousins, Bonaventure: The Soul's Journey, 35.

593 Bonaventure and Cousins, Bonaventure: The Soul's Journey 148.

${ }^{594}$ Dansereau, Servasanto Da Faenza, 219. 
worship of Jesus' blood within and without the order. ${ }^{595}$ The artwork reflected this increased devotion. Beate Fricke points out that beginning in the 1270s, the painters of wood-panel crucifixes represented the stream of Jesus' blood with increased movement, attention to realistic flow and coagulation, and differentiation of color to indicate the passage of time. ${ }^{596}$ Fricke explains, "The more imminent Christ's death appears to be, the more vividly his blood appears to flow." ${ }^{, 597}$ Fricke observes that "Blood is an especially appropriate matter for the representation of different temporal dimensions within the same picture. It stays "alive" and wet for some time after the body's death before it dries." ${ }^{598}$ Francis at the foot of the cross, reacting to the flowing blood of Jesus, serves to connect the contemporary viewer with the historical Crucifixion. The blood dripping from the cross creates a sense of immediacy and presence for the believer, linking them, along with Francis, as witnesses to the physical anguish of Jesus.

In earlier depictions of the Crucifixion, from the Byzantine through Pisano's and even up to our examples from Arezzo, Perugia, and Montefalco, Jesus' feet are nailed separately to the cross. The Spello image, however, presents an early variation to this iconography. ${ }^{599}$ It emphasizes the painful curve of the ankle to accommodate a single nail

595 Derbes and Neff, “Byzantine Sphere,” 457.

${ }^{596}$ Information in this section is drawn from Beate Fricke, "A Liquid History: Blood and Animation in Late Medieval Art.," Peabody Museum of Archaeology and Ethnology and the Harvard University Art Museums 63/64 (2013): 54, 59, 61-63. Flowing blood can be compared to the Hebrew belief that moving water is "living water," compared to pooled or stagnant bodies of water.

${ }^{597}$ Fricke, "Liquid History," 54.

${ }^{598}$ Fricke, "Liquid History,” 59.

599 The first known imagery of a three-nail crucifixion was in Pisa on a pulpit's sculptural decoration by Nicola Pisano, dated in an inscription to 1260 . Bennett, "Stigmata and Sense Memory," 15. 
wound. Closely following the creation of the cross at Spello, the Pseudo-Bonaventuran text provided the first description of the Crucifixion using only three nails. Seemingly responsive to the growing personal agency of the laity, Pseudo-Bonaventure presented the manner in which Jesus was affixed to the cross in two potential historical situations. The writer invites the reader to choose whichever provides the more meaningful meditation. In the first scenario, Jesus ascended the cross on a ladder and was held there while soldiers embedded the nails. In the second, Jesus was nailed to the wood while lying on the ground and subsequently raised upright. In both scenarios, Jesus' arms were stretched and nails driven through his hands. His feet were bound with a single nail struck through both feet. It is conceivable that artwork, such as Spello's type of Crucifixion imagery, inspired the author(s) of the Meditations to compose their innovative narrative.

On the Spello panel, the blood from each extremity pours naturalistically, overflowing the lines of the cut down cross. The gash in Jesus' chest is especially prominent with blood emptying down toward the image of Francis at the base. The saint kneels at the feet of Jesus, leaning in toward the viciously large nail head above the toes. In her article, Sara Lipton examines the effects of this increasingly violent representation on the psyche of the congregation:

In suggesting that the heightened emphasis on Jesus's suffering embodied in the new iconography could well unsettle even faithful and orthodox Christians, the Meditation signals the power and autonomy of visual response. No matter how ardently viewers of art might believe in Christ the Savior (there is no reason to think that the Meditation was written for souls wavering in their faith), and no matter how familiar they might be with the narrative of the Crucifixion and the general form of the crucifix, they could still be shocked and distressed by an image of the dying Jesus, that is, by the appearance of a work of art. One did not have to be a heretic or a Jew to be worried by the visual similarities between the crucified God 
and dead and defeated mortal bodies-especially when their impact was not yet blunted by convention. ${ }^{600}$

Pseudo-Bonaventure frequently entreats the reader to "attend," "imagine," and

“be present” as he graphically describes Jesus' sufferings. ${ }^{601}$ He elaborates:

On all sides, rivers of His most sacred blood flow from his terrible wounds. He is so tortured that He can move nothing except His head. Those three nails sustain the whole weight of His body. He bears the bitterest pain and is affected beyond anything that can possibly be said or thought. ${ }^{602}$

The chest, sternum, and ribcage of Jesus, although they are more accurately portrayed than in the other torsos of our subgroup, are stylized to emphasize prominent bones. They are recalled in Pseudo-Bonaventure's words: "Behold, the Lord Jesus is crucified and extended on the cross so that each of His bones can be numbered." 603

It has been claimed that the downfall of Catharism can be attributed to Francis' dedication to the human nature of Jesus Christ more so than to military or inquisitional tactics. ${ }^{604}$ As a promotion of orthodox theology, the Franciscans' concentration on Jesus' physicality represented in images would have indeed alienated the heterodox adherents. They would not only have found it offensive that the Catholic witnessed the physical

${ }^{600}$ The Meditation Lipton discusses here is a Twelfth century manuscript of a follower of Bernard of Clairvaux. Nevertheless, her argument can be applied to the Franciscans' texts as they also elaborated on Bernadine themes. Lipton, "The Sweet Lean," 1186.

${ }^{601}$ Pseudo-Bonaventure, Ragusa, and Green, Meditations, 318, 320, 333, 318, 320, 333.

${ }^{602}$ Pseudo-Bonaventure, Ragusa, and Green, Meditations, 334.

${ }^{603}$ Pseudo-Bonaventure, Ragusa, and Green, Meditations, 334.

${ }^{604}$ See C.N.L. Brooke, "Heresy and Religious Sentiment 1000-1250", in The Bulletin of the Institute of Historical Research, 41 (1968) 115-31, David D'Avray, "Some Franciscan Ideas about the Body," Archivum Franciscanum Historicum, 84 (1991) 343. Both sources cited in Dansereau, Servasanto Da Faenza, 230-31. 
human nature of Jesus within the imagery of the Passion but would have rejected Catholic use of created artwork as a source of that belief. In contrast, from the beginning, the Order of Friars Minor valued the edifices of church buildings and their material accoutrements. Even while devoted to poverty, Francis felt it was his duty to repair churches. He exhorts his brothers: "The Lord gave me such faith in churches that I would pray with simplicity in this way and say: 'We adore You, Lord Jesus Christ, in all Your churches throughout the whole world and we praise You because by Your holy cross You have redeemed the world. ${ }^{\prime 05}$ While the Cathars shunned crucifixes as part of the evil of created matter, for Catholics the crucifix became the locus of adoration and theological thought. Amy Neff describes how the particularly Franciscan method of prayer in which the visual image is fully integrated engenders the divinization of the viewer, causing him or her to more closely resemble God. This approach to redemption brings us back to Francis, for it was made possible by the saint's fervent love of Christ. Neff explains:

[It] is on the cross that Christ fully descends to humankind's essential poverty, degradation, and humiliation. The suffering of Christ's Passion is explained as an abasement that is necessary in order to inflame human love and compassion; that love enables humans to join Christ in salvation. By engaging the viewer's heart, the image of the Passion draws out the viewer's emotions empathetically, in what is known as affective devotion. ${ }^{606}$

In the medieval conception of art, if a figural image elicited love from the viewer, it was believed to have the power to transform him or her into the likeness of the Divine. ${ }^{607}$ The Franciscans used the devotional tool of focusing on the physical suffering of Jesus with

${ }^{605}$ Armstrong and Francis, St. Francis of Assisi, 229-30.

${ }^{606}$ Neff, "Painting, Devotion, and the Franciscans," 38.

${ }^{607}$ Neff, "Painting, Devotion, and the Franciscans," 43. 
extreme effectiveness, beginning in the age when it was a response to the Cathars' rejection of Jesus' human body and continuing to our modern times. Francis' example of alter Christus encouraged followers to gaze on the image of Christ in the dipintura crucifixes, just as the saint had done, with the desire to similarly take on the aspect of Christ. In conclusion, the graphic depiction of the dead Christ on these large crucifixes, displayed in the most prominent place above the altar, became the main devotional focus of the Franciscans. Using artworks to promote orthodoxy among Catholic believers, they worked in an emotionally sophisticated yet approachable manner to thwart heresy in their wider communities. 


\section{Conclusion}

Despite the attempts of medieval and modern forces to expunge the Cathars from history, it is evident that this heterodox sect played an important role in shaping the thirteenth-century Italian milieu in which they co-existed with the Franciscans. The two groups were intertwined by their contrasting theology and comparable ascetic practices, bound in a struggle not only for earthly attention, but also to win souls for eternity. Through this study, I have highlighted significant iconographic themes that the friars developed to combat the dualist and docetist tenets of the Cathar faith. Through the Catholic mendicants' harshly ascetic lifestyle, their embrace of nature, and their devotion to the Incarnation, the Eucharist, and the Passion of Jesus Christ, the Order of Friars Minor transformed duecento lay piety through a rapidly changing visual landscape in response to the Cathars.

Following a discussion of the current (and at times contentious) state of the research, the early chapters of this dissertation examined the historical progression of both the Franciscans and the Cathars. Of particular note was each group's connection to materiality as a consequence of their theological beliefs. The spiritual roots of the painted wood panels positioned this medium as the ideal platform for the illustration of the friars' orthodox catechetical preaching. The ability to transport the lightweight wood-panel artwork increased the order's range of influence beyond the walls of the Church. In the third chapter, I made the argument that a major reason for the proliferation of Francis' image so closely following his death was the friars' intention to cast him as an orthodox counter-example to the Cathar Perfecti. In this section, I focused on the iconographic elements contained in the paintings: the habit, book, and cross. Through these symbols, 
Francis, and by extension his brothers, served as a foil to the Cathar elite in their public preaching. Even more crucially, artwork depicting Francis marked with the stigmata demonstrated to both believers and non-believers that he surpassed all other holy men, becoming an alter Christus. The fourth chapter explored the vita dossals with their multiple biographical and posthumous miracle stories. Looking at key themes of physical healing, the doctrines of the Incarnation and Real Presence, and the inherent goodness of the natural world, I presented the narrative scenes that most clearly challenged Cathar beliefs. We began to see how the Franciscans' appreciation of nature translated into greater detail and authenticity of representation. In the final chapter, we turned to the dipintura crosses of the order, examining the Byzantine origins of their iconography, the import of their liturgical placement, and their connection to the early Franciscan sermons and hagiographic tradition. Again, the themes of Incarnation and Eucharist were explored in the imagery, along with a more in-depth look at Jesus' physicality and the impact of his torture on the witnesses to his Passion. All these elements served, in a new way, to elicit powerful emotional responses from the medieval audiences who viewed the portrayals of both Jesus Christ and Francis.

Looking beyond the thirteenth-century timeframe of this study, further research potentially could trace an artistic transition as the Franciscans, as well as their contemporaries, more strongly embraced an Aristotelian worldview. While I reject the idea of a linear evolution, it is clear that later, celebrated artists such as Giotto, with their heightened sensitivity to naturalistic forms, built upon the foundations of their duecento predecessors. They may have stood beneath these early Franciscan dipintura panels and crosses, such as those in Siena or Spello-works that strongly emphasize material 
creation and the human form - and appreciated the corporeal ascendancy that these paintings portrayed.

The Cathars reached their peak influence in the mid-years of the duecento. Facing increased persecution by inquisitorial authorities allied with Guelf governments, the Cathars' declining population adopted a more secretive and secluded position in society after this time. By the early fourteenth century, the Cathars had withdrawn to more rural areas; until by 1320 they had abandoned the regions of Umbria, Tuscany, and Lazio for northern Italian regions. ${ }^{608}$ At the core of their demise was the disparity between their dualist philosophy of a damned world and the Christian mission to bring the Earth to sanctification. The Cathars' negative view of the created world did not permit beauty or goodness within this sensual life, but merely waited for death when the soul would be released. In contrast, the Franciscans recognized that one's earthly existence partook in both body and spirit, nature and transcendence. Suffering was an inescapable reality of human existence from birth to death, but by visually presenting the humanity of Jesus as a model of perseverance and humility even through pain, the brothers provided an artistic route to peace in the present moment. ${ }^{609}$

The conversation between Cathar and Franciscan belief and practice and their effect on the art of the period could continue in many further directions for research. In future studies, I hope to analyze the vita dossals in relation to model sermons preached by the friars. William Cook noted instances of symmetrical arrangements through several of

${ }^{608}$ Stephens, "Heresy in Florence," 49-50; Lansing, Power and Purity, 5.

${ }^{609}$ Dansereau came to a similar conclusion regarding the impact of the friars' preaching on suffering. Dansereau, Servasanto Da Faenza, 233-34. 
the historiated panels. Building on Cook's observations and sermon studies by David D’Avray, Raymond Dansereau, and Bert Roest, I theorize that this illustrated format may mirror the organization of model sermons "whose parts start from a single point and fan out artistically...like a symmetrical family tree of notions, each supported by a text."610 This can be visualized in the vita dossals as the central image of Francis, fanning into narrative scenes from his life, divided into symmetrical visual or textual themes. As more Franciscan sermons receive critical attention, it would be valuable to compare their content and structure with that of visual representations on the wood panels as well as in manuscript decoration.

Another route for continued research would be to perform a much-needed iconographic study of the Bible of Lyons (Ms PA 36 from the Municipal Library of Lyon). Anne Brenon analyzed this work in regard to its textual sources, yet the manuscript's thirty calligraphic incipits call for a thorough investigation. They appear to be unique in their geometric abstraction among other thirteenth-century manuscript examples. With their non-figural decoration, they may signify Cathar reclamation of Byzantine motifs from the era of the iconoclastic controversy or possibly an Islamic influence. ${ }^{611}$ Although only this one Cathar document contains decoration, the other rare heterodox texts also could be analyzed in relationship to early Franciscan artwork to explore how ideas may have transferred between the two groups. So much evidence regarding the Cathars' history, theology, and way of life has been lost, making it

${ }^{610}$ D'Avray, Preaching of the Friars, 176.

${ }^{611}$ Despite Brenon calling for this work in 1998, it remains undone. Brenon et al., "Cathars and the Representation," 254-56. 
imperative that their remaining documents be explored as thoroughly as possible. This will allow researchers to ascertain how the broader European culture responded to, and was altered by, this powerful and diverse heterodox community.

As an aniconic faith, the artistic impact of the Cathars understandably has been neglected. Yet their dualist beliefs motivated the thirteenth-century friars to creatively pour forth visual and material resources, producing painted and portable theology for the promotion of orthodox doctrine. The early Franciscans' icons, vita dossals, and monumental crucifixes serve as a framework for exploring the comparable yet contrasting faiths that the Friars Minor and the Cathars maintained within parallel communities. Once again, we can ask why there was such a dramatic transition in early Franciscan art that turned from a Byzantine style to increasing degrees of naturalistic, realistic, emotional, and corporeal representations. What conditions prompted the Order of Friars Minor to become one of the most prolific and innovative patrons of the arts in duecento Italy? As this dissertation has hopefully elucidated, the Cathars and the early Franciscans' artistic reaction to them provide crucial answers to these questions. 


\section{Bibliography}

\section{Primary Sources}

Bernard of Clairvaux. Life and Works of Saint Bernard, Abbot of Clairvaux: Volume 4: Cantica Canticorum Eighty-Six Sermons On The Song Of Solomon. Edited by Jean Mabillon. Translated by Samuel J. Eales. London: J. Hodges, 1889. http://archive.org/details/LifeAndWorksOfSaintBernardV4.

Bonaventure. The Life of St. Francis. Translated by E. Gurney Salter. Charles River Editors, 2013.

Bonaventure, and Ewert Cousins. Bonaventure: The Soul's Journey into God; The Tree of Life, The Life of St. Francis. New York: Paulist Press, 1978.

Bonaventure, and Eric Doyle. The Disciple and the Master: St. Bonaventure's Sermons on St. Francis of Assisi. Chicago, IL: Franciscan Herald Press, 1984.

Cennini, Cennino D'Andrea, and Daniel V. Thompson. The Craftsman's Handbook. New York: Dover Publications, 1960.

Francis of Assisi. St. Francis of Assisi: Writings and Early Biographies: English Omnibus of the Sources for the Life of St. Francis. Edited by Marion A. Habig. Chicago: Franciscan Herald Press, 1973.

Francis of Assisi, and Commission on the Franciscan Intellectual Tradition. "The Admonitions." Accessed June 6, 2020. https://franciscantradition.org/francis-ofassisi-early-documents/the-saint/writings-of-francis/the-undated-writings/theadmonitions/144-fa-ed-1-page-128.

Lateran Council, and Fordham University Internet History Sourcebooks Project. "Medieval Sourcebook: Twelfth Ecumenical Council: Lateran IV 1215." Accessed June 4, 2020. https://sourcebooks.fordham.edu/basis/lateran4.asp.

Pseudo-Bonaventure, Isa Ragusa, and Rosalie Green. Meditations on the Life of Christ; An Illustrated Manuscript of the Fourteenth Century. Princeton Monographs in Art and Archaeology 35. Princeton, N.J: Princeton University Press, 1961.

Thomas of Celano, Regis J. Armstrong, J. A. Wayne Hellmann, William J. Short. The Francis Trilogy of Thomas of Celano: The Life of Saint Frances, The Remembrance of the Desire of a Soul, The Treatise on the Miracles of Saint Francis. Hyde Park, N.Y.: New City Press, 2004.

Thomas of Celano, and Commission on the Franciscan Intellectual Tradition. "The Life of Saint Francis by Thomas of Celano: Vita Prima." Accessed June 5, 2020. 
https://franciscantradition.org/francis-of-assisi-early-documents/the-saint/the-lifeof-saint-francis-by-thomas-of-celano/698-fa-ed-1-page-254.

Thomas of Celano, and Commission on the Franciscan Intellectual Tradition, Treatise on the Miracles. "The Treatise on the Miracles of Saint Francis." Accessed June 4, 2020. https://franciscantradition.org/francis-of-assisi-early-documents/thefounder/the-treatise-on-the-miracles-of-saint-francis/1530-fa-ed-2-page-442.

Thomas of Celano, and Jacques Dalarun. The Rediscovered Life of St. Francis of Assisi. Translated by Timothy J. Johnson. St. Bonaventure University: Franciscan Institute Publications, 2016.

Vasari, Giorgio, Julia Conaway Bondanella, and Peter Bondanella. Lives of the Artists. Oxford World's Classics. Oxford University Press, 1998.

\section{Secondary Sources}

Ahlquist, Gregory, and William Cook. "The Representation of the Posthumous Miracles of St Francis of Assisi in Thirteenth-Century Italian Painting." Art of the Franciscan Order in Italy, 2005, 211-56.

Armstrong, Regis. St. Francis of Assisi: Writings for a Gospel Life. Crossroad Spiritual Legacy Series. New York: Crossroad, 1994.

Artstor. "Crucifixion with Saint Francis." Artwork. Accessed June 29, 2020. http://library.artstor.org/\#/asset/SCALA_ARCHIVES_10310197142.

Baldini, Umberto and Ornella Casazza. The Crucifix by Cimabue. Italy: Olivetti, 1980.

Bałdyga, Sergiusz M. The San Damiano Cross. Assisi: Edizioni Porziuncola, 2005.

Baxandall, Michael. The Limewood Sculptors of Renaissance Germany, 1475-1525: Images and Circumstances. New Haven: Yale University Press, 1980.

Bennett, J. "Stigmata and Sense Memory: St Francis and the Affective Image." Art History 24 (2001): 1-16.

Biller, Peter. "Cathars and the Material World." In God's Bounty?: The Churches and the Natural World, edited by Peter Clarke and Tony Claydon. Woodbridge, Suffolk, UK; Rochester, NY: Ecclesiastical History Society; Boydell \& Brewer, 2010.

—. "Goodbye to Catharism?" In Cathars in Question, edited by Antonio Sennis. Woodbridge, Suffolk: York Medieval Press, 2016. 
Biller, Peter, and Alastair Minnis. Medieval Theology and the Natural Body. Suffolk; Rochester, N.Y.: York Medieval Press, 1997.

Boccia, Lionello Giorgio, Anna Maria Maetzke, Carla Corsi, and Albino Secchi. Arte nell'Aretino: recuperi e restauri dal 1968 al 1974 : Arezzo, San Francesco, 14 dicembre 1974-2 febbraio 1975. Firenze: Edam, 1974.

Bolland, Andrea. "Art and Humanism in Early Renaissance Padua: Cennini, Vergerio and Petrarch on Imitation." Renaissance Quarterly 49, no. 3 (1996): 469-87. https://doi.org/10.2307/2863363.

Bollati, Milvia, and Carlo Fadin. Francesco e la Croce di S. Damiano. Fonti e Ricerche 25. Milano: Edizioni Biblioteca Francescana, 2016.

Bomford, David. "Introduction: Keynote Address." In The Structural Conservation of Panel Paintings: Proceedings of a Symposium at the J. Paul Getty Museum, 2428 April 1995., by Kathleen Dardes and Andrea Rothe. Los Angeles: Getty Conservation Institute, 2013.

Bragadin, Gian Marco. S. Francesco: Le Verità Nascoste: l'Amore per Chiara, $i$ Templari, i Sufi, i Catari, Tutti i Misteri di Assisi, Torino: Melchisedek, 2016.

Brenon, Anne. "The Occitan Cathar Manuscript of Dublin (Ms 269 Tcd): A Unique Window into Dissident Religiosity." In From Carrickfergus to Carcassonne: the epic deeds of Hugh de Lacy during the Albigensian crusade, edited by Paul R. Duffy, Tadhg O'Keeffe, and Jean-Michel Picard, 2017.

Brenon, Anne. "Cathars and the Representation of the Divine: Christians of the Invisible." In Women Preachers and Prophets through Two Millennia of Christianity. Berkeley: University of California Press, 1998.

Brooke, Rosalind B. The Image of St Francis: Responses to Sainthood in the Thirteenth Century. Cambridge: Cambridge University Press, 2009.

Bruschi, Caterina. "Converted-Turned-Inquisitors and the Image of the Adversary: Ranier Sacconi Explains Cathars." In Cathars in Question, edited by Antonio Sennis. University of York, 2018.

Brubaker, Leslie. Inventing Byzantine Iconoclasm. London : Bristol Classical Press, 2012.

Burr, David. Spiritual Franciscans: From Protest to Persecution in the Century After Saint Francis. Penn State Press, 2010. 
Bynum, Caroline Walker. "The Body of Christ in the Later Middle Ages: A Reply to Leo Steinberg." Renaissance Quarterly / Publ. by the Renaissance Society of America., 1986, 399-439.

Camille, Michael. The Gothic Idol: Ideology and Image-Making in Medieval Art. Cambridge: Cambridge Univ. Press, 1989.

Cannon, Joanna. "Reviews of Exhibitions: The Era of the Great Painted Crucifix: Giotto, Cimabue, Giunta Pisano, and Their Anonymous Contemporaries." Renaissance Studies 16, no. 4, 2002: 566-81.

Caroselli, Susan L. Italian Panel Painting of the Early Renaissance: In the Collection of the Los Angeles County Museum of Art. Los Angeles; Washington: County Museum : University of Washington Press, 1994.

Caviness, Madeline Harrison. Art in the Medieval West and Its Audience. Aldershot: Ashgate, 2001.

Caviness, Simple, Madeline H. "“The Simple Perception of Matter' and the Representation of Narrative, ca. 1180-1280." In Art in the Medieval West and Its Audience, III, 1-17. Aldershot: Ashgate, 2002.

Ciatti, Marco. Pinxit Guillielmus -Il Restauro della Croce di Sarzana. Firenze: Edifir, 2001.

Clement, Geoffrey Ward. “A Franciscan Inquisitor's Manual and Its Compositional Context: 'Codex Casanatensis' 1730.” ETD Collection for Fordham University, January 1, 2013, 1-372.

Cook, William. "Fraternal and Lay Images of St. Francis in the Thirteenth Century." In Popes, Teachers, and Canon Law in the Middle Ages, edited by James Ross Sweeney and Stanley Chodorow. Ithaca: Cornell University Press, 1989.

- Images of St. Francis of Assisi: In Painting, Stone, and Glass: From the Earliest Images to ca. 1320 in Italy: A Catalogue. Firenze; Perth [W.A.]: L.S. Olschki; Dept. of Italian of the University of W. Australia, 1999.

—. "Margarito d'Arezzo's Images of St Francis: A Different Approach to Chronology." Arte Cristiana / a Cura Della Scuola Beato Angelico e Dell'Istituto Di Storia Dell'Arte Dell'Università Cattolica, Associata al Centro d'Azione Liturgica e All'Unione Della Stampa Periodica Italiana., 1995, 83-90.

."My Life with Francis." In The World of St. Francis of Assisi: Essays in Honor of William R. Cook, edited by Bradley Franco and William Cook. Boston: Brill, 2015. 
— "New Sources, New Insights: The Bardi Dossal of the Life of St. Francis of Assisi." Studi Francescani. Firenze 93, 1996, 325-46.

_. "The Orte Dossal: A Traditional and Innovative Life of St. Francis of Assisi." Arte Medievale / Istituto Della Enciclopedia Italiana. 2, 1996, 41-47.

—. "The St. Francis Dossal in Siena: An Important Interpretation of the Life of Francis of Assisi." Archivum Franciscanum Historicum., 1994, 3-20.

Cooper, Donal. "Experiencing Dominican and Franciscan Churches in Renaissance Italy." In Sanctity Pictured: The Art of the Dominican and Franciscan Orders in Renaissance Italy, edited by Trinita Kennedy, 2014.

_ . "In Loco Tutissimo e Firmissimo': The Tomb of St. Francis in History, Legend and Art." Art of the Franciscan Order in Italy / Ed. by William R. Cook., 2005, 137.

__ . "Preaching Amidst Pictures: Visual Contexts for Sermons and Late Medieval Tuscany." In Optics, Ethics, and Art in the Thirteenth and Fourteenth Centuries: Looking into Peter of Limoges's Moral Treatise on the Eye, 29-45. Toronto, Ontario,: Pontifical Institute of Medieval Studies, 2018.

_ . "Projecting Presence: The Monumental Cross in the Italian Church Interior." Presence / Ed. by Robert Maniura and Rupert Sheperd., 2006, 47-69.

Cooper, Donal, and Janet Robson. The Making of Assisi: The Pope, the Franciscans and the Painting of the Basilica. New Haven: Yale University Press, 2013.

Cooper, Donal, Warburg Institute, and Courtauld Institute of Art. Franciscan Choir Enclosures and the Function of Double-Sided Altarpieces in Pre-Tridentine Umbria. London: Warburg Institute, 2001.

Dansereau, Raymond, Rutgers Graduate School-New Brunswick, and Graduate SchoolNew Brunswick. Servasanto Da Faenza: Preaching and Penance in the Work of a Thirteenth-Century Franciscan, 2015. http://dx.doi.org/doi:10.7282/T3833TQ3.

D’Avray, David L. The Preaching of the Friars: Sermons Diffused from Paris Before 1300. Oxford, England: Oxford University Press, 1985.

- Medieval Marriage: Symbolism and Society. Oxford: Oxford University Press, 2008.

De Vecchi, Pierluigi, Pinacoteca Comunale (Gualdo Tadino), Umbria, and Servizio Musei e Beni Culturali. Museo Civico di Gualdo Tadino. decorazione murale, dipinti, materiali lapidei, sculture, arredo civile ed ecclesiastico, tessuti 1, 1. Perugia: Electa Editori Umbri Associati, 2000. 
Debby, Nirit Ben-Aryeh. "The Preacher as Goldsmith: The Italian Preacher's Use of the Visual Arts." Preacher, Sermon and Audience in the Middle Ages, edited by Carolyn Muessig, 2002, 127-53.

Derbes, Anne. Picturing the Passion in Late Medieval Italy: Narrative Painting, Franciscan Ideologies, and the Levant. Cambridge; New York: Cambridge University Press, 1996.

Derbes, Anne, and Amy Neff. "Italy, the Mendicant Orders, and the Byzantine Sphere." In Byzantium: Faith and Power (1261-1557), edited by Helen C. Evans. New Haven: Yale University Press, 2004.

The Art Institute of Chicago. "Doctrine and Devotion: Art of the Religious Orders in the Spanish Andes, March 19, 2016-June 25, 2017.” Accessed June 10, 2020. https://www.artic.edu/exhibitions/2493/doctrine-and-devotion-art-of-thereligious-orders-in-the-spanish-andes.

Eliade, Mircea. Images and Symbols: Studies in Religious Symbolism. Princeton, N.J.: Princeton University Press, 1991.

Fletcher, John. "Panel Examination and Dendrochronology." J. Paul Getty Museum Journal / J. Paul Getty Museum, 1982, 39-44.

Flora, Holly. The Devout Belief of the Imagination the Paris "Meditationes Vitae Christi" and Female Franciscan Spirituality in Trecento Italy. Turnhout: Brepols, 2009.

Franciscan Intellectual Tradition. "Franciscan Intellectual Tradition.” Accessed June 10, 2020. https://franciscantradition.org/.

Franco, Bradley R. "The Functions of Franciscan Art.” In The World of St. Francis of Assisi: Essays in Honor of William R. Cook, edited by Steven J. McMichael, 1944. Leiden: Brill, 2015.

Frascaroli, Fabrizio. "Catholicism and Conservation: The Potential of Sacred Natural Sites for Biodiversity Management in Central Italy." Humanecology Human Ecology 41, no. 4, 2013, 587-601.

Fricke, Beate. "A Liquid History: Blood and Animation in Late Medieval Art." Peabody Museum of Archaeology and Ethnology and the Harvard University Art Museums 63/64, 2013, 53-69.

Garrison, Edward B. Italian Romanesque Panel Painting: An Illustrated Index. New York: Hacker Art Books, 1976. 
— . "Note on the Survival of Thirteenth-Century Panel Paintings in Italy." Artbulletin The Art Bulletin 54, no. 2, 1972, 140.

Givens, Jean A. Observation and Image-Making in Gothic Art. New York: Cambridge University Press, 2004.

Goffen, Rona. Spirituality in Conflict: Saint Francis and Giotto's Bardi Chapel, University Park: Pennsylvania State University Press, 1988.

Hammond, Jay M. "Preaching by Image: The Counter Façade of the Basilica of St. Francis." In Franciscans and Preaching / Ed. by Timothy J. Johnson., 413-50, 2012.

Hammond, Jay M., J. A. Wayne Hellmann, and Jared Goff. A Companion to Bonaventure. Leiden: Brill, 2014.

The Metropolitan Museum of Art. "Heavenly Bodies: Fashion and the Catholic Imagination, May 10-October 8, 2018.” Accessed June 10, 2020.

https://www.metmuseum.org/exhibitions/listings/2018/heavenly-bodies.

Herbst, Thomas. "Franciscan Christology in the Development of the Iconography of the Passion.” Academia.Edu, March 2006.

https://www.academia.edu/28815731/Franciscan_Christology_in_the_Developme nt.

- "Franciscan Christology in the Development of the Iconography of the Passion." The Cord: A Franciscan Spiritual Review 59, no. 3, September 2009.

-. "The Humanization of Christ in the Central Italian Panel Crucifixes of the Twelfth and Thirteenth-Centuries Reflected in the Development of Franciscan Christology.” Masters Thesis, Franciscan School of Theology, Graduate Theological Union, 1989.

Herlihy, David. "Book Review: 'Montaillou': Cathars and Catholics in a French Village, 1294-1324.” Social History 4, no. 3, 1979, 517-20.

"Il Crocifisso di San Damiano Torna (Temporaneamente) a 'Casa': le Foto." AssisiNews, June 15, 2016. https://www.assisinews.it/speciali/crocifisso-di-san-damianotorna-casa-foto/.

Irish Franciscans. "The Writings of St. Francis." The Writings of Francis. Accessed June 4, 2020. https://www.franciscans.ie/the-writings-of-st-francis/.

Jones, Nathaniel B. “Ancient Painted Panels: Terminology and Appearance.” Mnemosyne 67, no. 2, 2014, 295-304. 
Kaelber, Lutz. Schools of Asceticism: Ideology and Organization in Medieval Religious Communities, University Park, Pennsylvania: Pennsylvania State University Press, 1998.

Kennedy, Trinita, Donal Cooper, Holly Flora, Amy Neff, and Janet Robson. Sanctity Pictured: The Art of the Dominican and Franciscan Orders in Renaissance Italy. Nashville: Frist Center for the Visual Arts, 2014.

Kennedy, Trinita, Donal Cooper, Holly Flora, Amy Neff, Janet Robson, Frist Center for the Visual Arts, and Frist Center for the Visual Arts. Sanctity Pictured: The Art of the Dominican and Franciscan Orders in Renaissance Italy. London: Philip Wilson Publishers, 2014.

Kessler, Herbert L. Seeing Medieval Art. North York, Ontario: University of Toronto Press, 2011.

- Spiritual Seeing: Picturing God's Invisibility in Medieval Art. Philadelphia: University of Pennsylvania Press, 2000.

Kienzle, Beverly Mayne. "Medieval Sermons and Their Performance: Theory and Record." In Preacher, Sermon and Audience in the Middle Ages, edited by Carolyn Muessig, 89-124. Leiden: Brill, 2002.

Kiser, L. J. "Animal Economies: The Lives of St. Francis in Their Medieval Contexts." Interdisciplinary Studies in Literature and Environment Interdisciplinary Studies in Literature and Environment 11, no. 1, 2004, 121-38.

- "The Garden of St. Francis: Plants, Landscape, and Economy in ThirteenthCentury Italy." Environmental History. 8, no. 2, 2003, 229-45.

Lambert, Malcolm. The Cathars. Oxford. UK; Malden, Mass., USA: Blackwell Publishers, 1998.

Lansing, Carol. Power and Purity: Cathar Heresy in Medieval Italy. New York: Oxford University Press, 2001.

Le Roy Ladurie, Emmanuel. Montaillou: The Promised Land of Error. New York: G. Braziller, 1978.

Léglu, Catherine, ed. The Cathars and the Albigensian Crusade: A Sourcebook. London: Routledge, 2014.

Lewis, P. S. Review of Montaillou, Village Occitan, de 1294 à 1324, by Emmanuel Le Roy Ladurie. The English Historical Review 92, no. 363 (1977): 371-73. 
Lipton, Sara. “The Sweet Lean of His Head': Writing about Looking at the Crucifix in the High Middle Ages." Speculum 80, no. 4, 2005, 1172-1208.

Lunghi, Elvio. "Francis of Assisi in Prayer Before the Crucifix in the Accounts of the First Biographers." Studies in the History of Art / Publ. by the National Gallery of Art, Washington., 2002, 340-53.

Mark Gregory Pegg. "The Paradigm of Catharism; or, The Historians' Illusion.” In Cathars in Question, edited by Antonio Sennis. Woodbridge, Suffolk: York Medieval Press, 2016.

McNamer, Sarah. Meditations on the Life of Christ: The Short Italian Text. Notre Dame: University of Notre Dame Press, 2018.

Moore, Robert I. The Formation of a Persecuting Society: Power and Deviance in Western Europe, 950-1250. Oxford: Basil Blackwell, 1987.

_ . "Principles at Stake: The Debate of April 2013 in Retrospect." In Cathars in Question, edited by Antonio Sennis. Woodbridge, Suffolk: York Medieval Press, 2016.

- The Birth of Popular Heresy. Toronto: University of Toronto Press in association with the Medieval Academy of America, 1995.

—. The War on Heresy. Erscheinungsort nicht ermittelbar: Belknap Harvard, 2014.

Moorman, John. A History of the Franciscan Order: From Its Origins to the Year 1517. Oxford: Oxford University Press, 1998.

Mormandi, Giuseppina. "Il culto della Santa Croce nella diocesi di Luni-Sarzana." Giornale storico della Lunigiana e del territorio lucense / Istituto Internazionale di Studi Liguri, Sezione Lunense, La Spezia ; Sezione Lucense, Lucca, 2016.

Muessig, C.A. Preacher, Sermon, and Audience in the Middle Ages. Leiden, Netherlands: Brill, 2002.

Muessig, Carolyn. The Stigmata in Medieval and Early Modern Europe. Oxford: Oxford University Press, 2020.

New Orleans Art Museum. "Arte Sacre: Roman Catholic Art from Portuguese India, March 13th, 2020 - June 20th, 2021." New Orleans Museum of Art. Accessed June 10, 2020. https://noma.org/exhibitions/arte-sacre-roman-catholic-art-fromportuguese-india/.

Nouwen, Henri. Behold the Beauty of the Lord: Praying with Icons. Notre Dame, IN: Ave Maria Press, 2007. 
Orlandos, Anastasios K. Pitsà. Roma: Enciclopedia dell' Arte Classica e Orientale. 6Roma: Istituto dell' Enciclopedia Italiana Fondata da Giovanni Treccani, 1964.

Ouspensky, Léonide, and Vladimir Lossky. The Meaning of Icons. Crestwood, NY: St. Vladimir's Seminary Press, 1999.

Pallis, Dimitrios. "A Critical Presentation of the Iconology of St. John of Damascus in the Context of the Byzantine Iconoclastic Controversies." Heythrop Journal 56 (2): 173-91, 2015.

Pani Ermini, Letizia, Maria Grazia Fichera, Maria Letizia Mancinelli, and Filippo Ermini. Indagini Archeologiche nella Chiesa di San Damiano in Assisi. S. Maria degli Angeli, Italy: Porziuncola, 2005.

Paolini, Lorenzo. "Italian Catharism and Written Culture." In Heresy and Literacy, 10001530, edited by Peter Biller and Anne Hudson. Cambridge [England]; New York, NY, USA: Cambridge University Press, 1996.

Pegg, Mark Gregory. "Albigenses in the Antipodes: An Australian and the Cathars." Journal of Religious History 35, no. 4 (December 2011): 577-600. https://doi.org/10.1111/j.1467-9809.2011.01143.x.

- The Corruption of Angels: The Great Inquisition of 1245-1246. Princeton, NJ: Princeton University Press, 2001.

Pistoia (Italy), Museo Civico, Maria Cecilia Mazzi, and Pistoia (Italy). Museo civico di Pistoia: Catalogo delle Collezioni. Firenze: La Nuova Italia, 1982.

Plested, Marcus. "The Influence of St John Chrysostom in the West.” Istanbul, Turkey, 2007. https://www.iocs.cam.ac.uk/wpcontent/uploads/st_john_chrysostom_in_the_west.pdf.

Polecritti, Cynthia L. Preaching Peace in Renaissance Italy: Bernardino of Siena \& His Audience. Washington, D.C.: Catholic University of America Press, 2000.

Rete Natura 2000 Il Progetto Siti Natura 2000 del Comune di Spoleto. "Signage at Monteluco," 2000.

Rezunyk, Jessica. "Science and Nature in the Medieval Ecological Imagination." Washington University in St. Louis, Washington University Open Scholarship Winter 12-15-2015, Accessed August 25, 2019, https://openscholarship.wustl.edu/art_sci_etds/677/.

Rice, David Talbot. Byzantine Painting: The Last Phase. New York: Dial Press, 1968. 
Roest, Bert. Franciscan Literature of Religious Instruction before the Council of Trent. Leiden, Netherlands: Brill, 2004.

Ruppar, Rebecca. "Cross Cult[Ural]: The Cross of San Damiano and the Earlier Saints of Assisi.” In Vernacular Theology and Medieval Franciscans (The Franciscan Institute, St. Bonaventure University). Western Michigan University, Kalamazoo, Michigan, 2019.

- "The Painted Panel Crucifixes of the Early Franciscans as a Response to the Cathar Heresy.” Masters Thesis, University of Missouri, 2016.

Sahli, Alejandra Concha. The Meaning of the Habit: Religious Orders, Dress and Identity, 1215-1650. University College London, 2017.

https://discovery.ucl.ac.uk/id/eprint/1546082/1/Concha_Alejandra_PhD_Thesis20 17.pdf.

Sennis, Antonio. Cathars in Question. York: York Medieval Press, 2018.

Sorrell, Roger. St. Francis of Assisi and Nature: Tradition and Innovation in Western Christian Attitudes toward the Environment. Milton Keynes: Lightning Source, 2010.

Steinberg, Leo. The Sexuality of Christ in Renaissance Art and in Modern Oblivion. New York: Pantheon Books, 1983.

Stephens, John N. "Heresy in Medieval and Renaissance Florence." Past \& Present, Oxford University Press, no. 54, 1972, 25-60.

Tartuferi, Angelo, Francesco D'Arelli, and Italie Museo dell'Accademia Firenze. L'Arte di Francesco: Capolavori d'Arte Italiana e Terre d'Asia dal XIII al XV secolo : Firenze, Galleria dell'Accademia, 31 Marzo - 11 Ottobre 2015. Firenze: Giunti, 2015.

Thompson, Augustine. Revival Preachers and Politics in Thirteenth-Century Italy: The Great Devotion of 1233, Eugene, Oregon: Wipf and Stock, 2010.

Torriti, Paolo, ed. Al tempo del beato Mansueto: Castiglion Fiorentino e il suo Territorio nel Duecento. Firenze: Scramasax, 2006.

Toscano, Bruno, and Bruno Toscano. Museo Comunale di San Francesco a Montefalco. Catalogo Regionale dei Beni Culturali dell'Umbria, Perugia: Electa, Ed. Umbri Assoc., 1990.

Tóth, Peter, and Dávid Falvay. "New Light on the Date and Authorship of the Meditationes Vitae Christi." In Diverse Imaginations of Christ's Life, by Kelly Stephen and Ryan Perry, Turnhout: Brepols, 2015. 
Uzielli, Luca. "Historical Overview of Panel-Making Techniques in Central Italy." In The Structural Conservation of Panel Paintings: Proceedings of a Symposium at the J. Paul Getty Museum, 24-28 April 1995, by Kathleen Dardes and Andrea Rothe. Los Angeles: Getty Conservation Institute, 2013.

Vatican News. "Pope Consecrates Synod for the Amazon to Saint Francis of Assisi," October 4, 2019. https://www.vaticannews.va/en/pope/news/2019-10/pope-synodamazon-saint-francis-vatican-gardens.html.

Wakefield, Walter. "The Treatise Against Heretics of James Capelli; A Study of Medieval Writing and Preaching Against Catharan Heresy." PhD Dissertation, Columbia University, 1951.

Wakefield, Walter L., and Austin P. Evans. Heresies of the High Middle Ages. Records of Civilization, Sources and Studies, no. 81. New York: Columbia University Press, 1969.

White, Lynn. "The Historical Roots of Our Ecologic Crisis.” Science 155, no. 3767 (March 10, 1967): 1203-7. https://doi.org/10.1126/science.155.3767.1203.

Zawart, Anscar. The History of Franciscan Preaching and of Franciscan Preachers; (1209-1927; A Bio-Bibliographical Study. New York: Wagner, 1928.

Zuppante, Abbondio. “(In Press) L'Eresia Nella Tuscia Del Duecento e Il Dossale Di San Francesco Di Orte." Edited by C. Canonici, F. De Macedo. Faleritanum. Rivista Di Teologia e Scienze Religiose Aracne; Anno III, 2018. 
Figures

Chapter 2 Art and Materiality

Figure 2.1 Maestro del Crocifisso di Gualdo Tadino, Crocifisso con San Francesco (verso), Museo Civico Rocca Flea, Gualdo Tadino

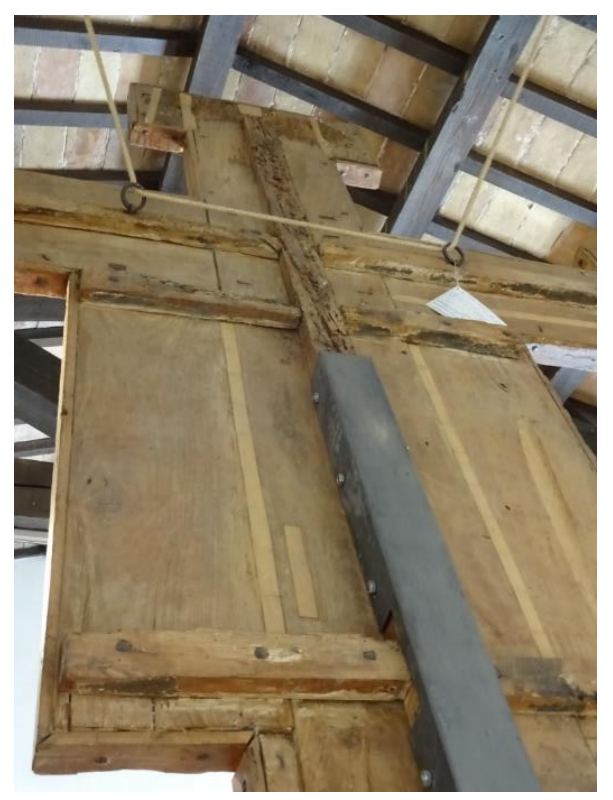

Photo by author

Figure 2.2 Maestro del Crocifisso di Gualdo Tadino, Crocifisso con San Francesco (verso, detail of fabric underlayer between boards), Museo Civico Rocca Flea, Gualdo Tadino

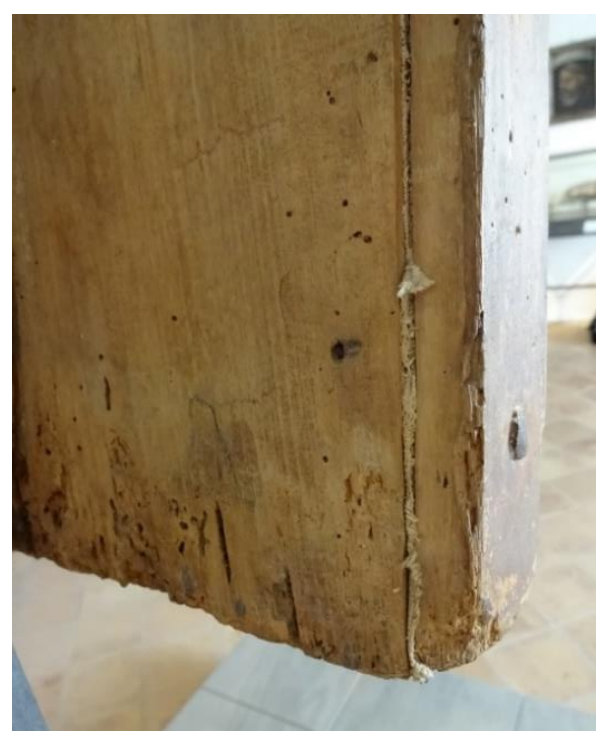

Photo by author 
Figure 2.3 Expressionist Master of Santa Chiara, Cristo Crocifisso, Chiesa Museo di San Francesco, Montefalco (detail showing fabric underlayer between wood and gesso)

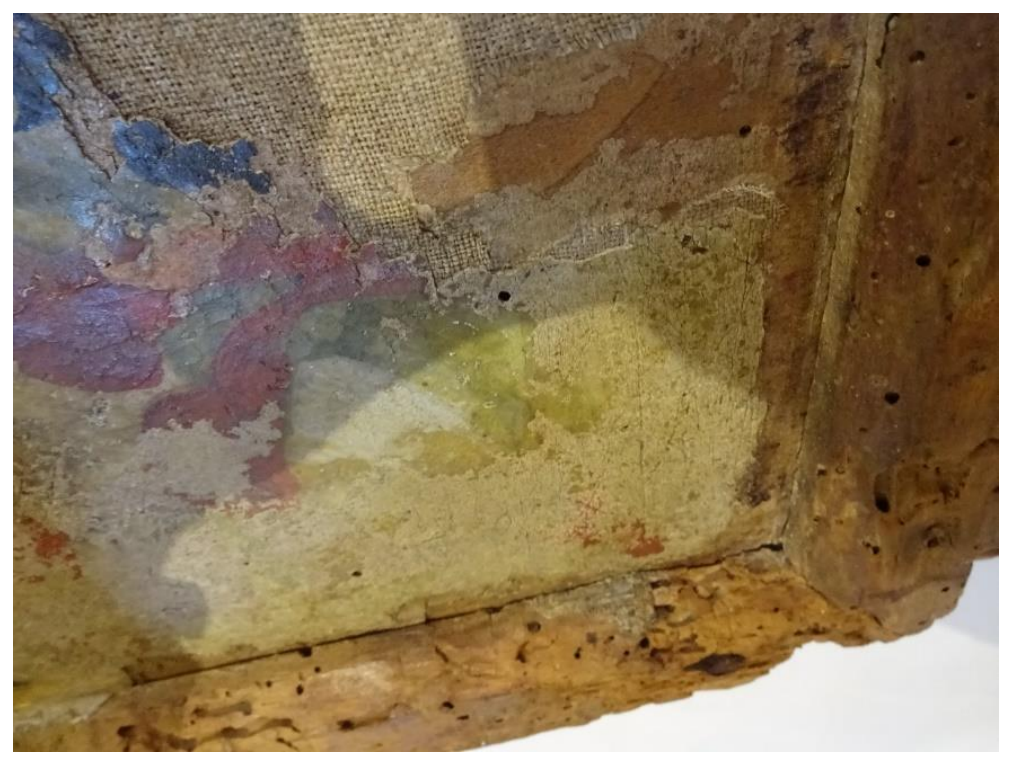

Photo by author

Figure 2.4 Maestro del San Francesco di Orte, San Francesco e Quattro Scene (detail of moldings), Museo d'Arte Sacra di Orte

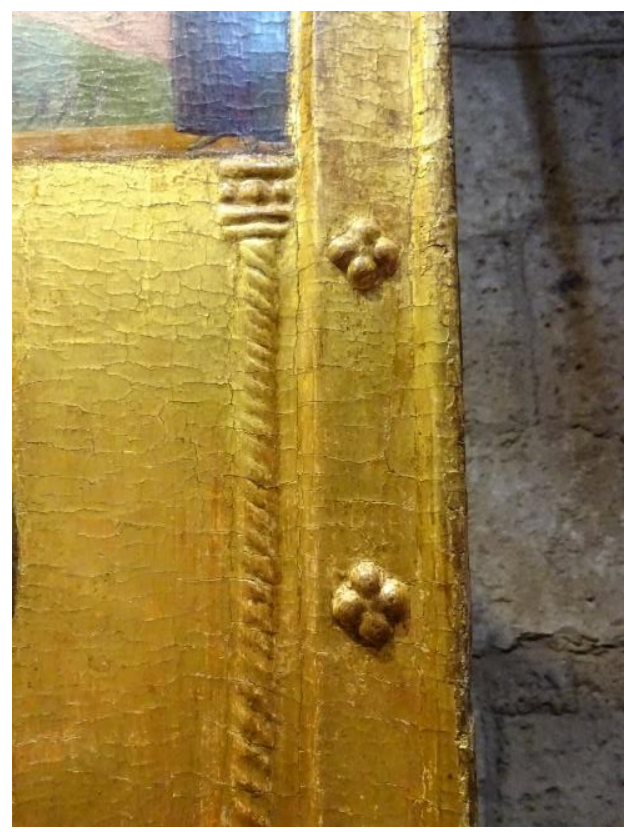

Photo by author 
Figure 2.5 Guido di Graziano (Guido of Siena), San Francesco e Storie della sua Vita (detail, compass guided, stamped and etched halo), Pinacoteca Nazionale di Siena (Formerly in San Francesco in Colle Val d'Elsa)

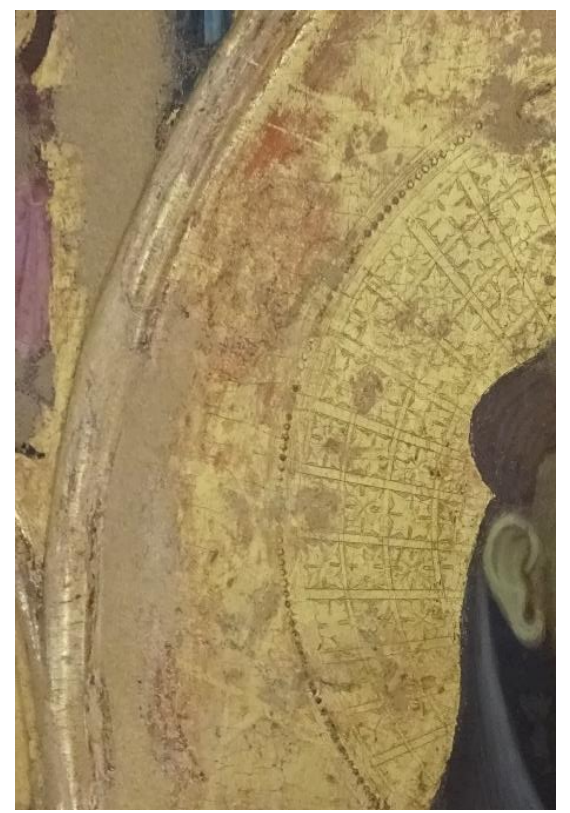

Photo by author

Figure 2.6 Lex Lucis Spoletina, environmental law at Monteluca

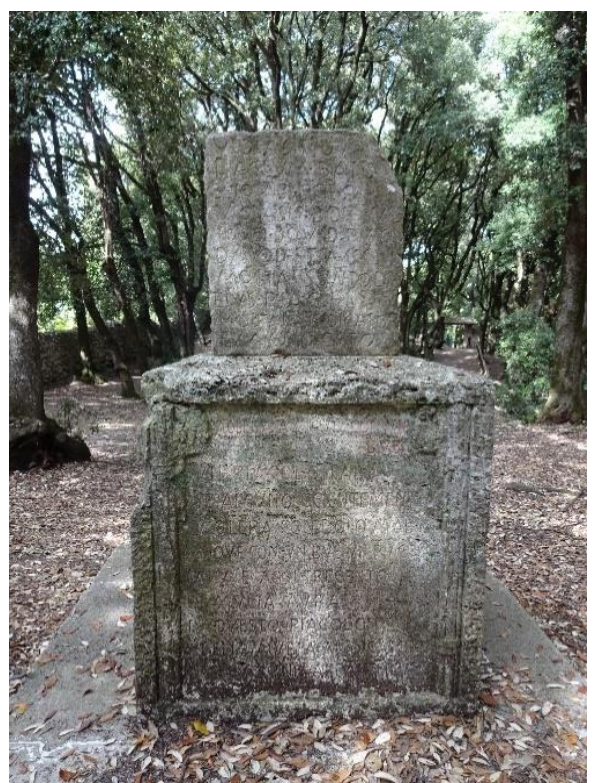

Reproduction of original that is now stored in the Spoleto Archeological Museum, photo by author 
Figure 2.7 View of the Spoleto Valley from Monteluco

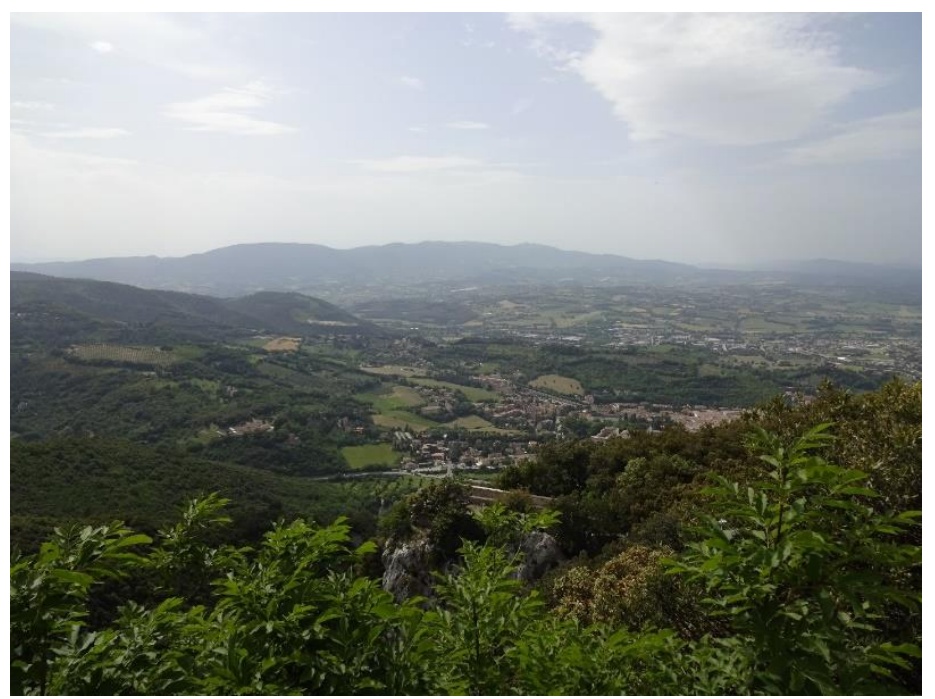

Photo by author

Figure 2.8 Margarito d'Arezzo, San Francesco, Pinacoteca Comunale, Castiglion Fiorentino

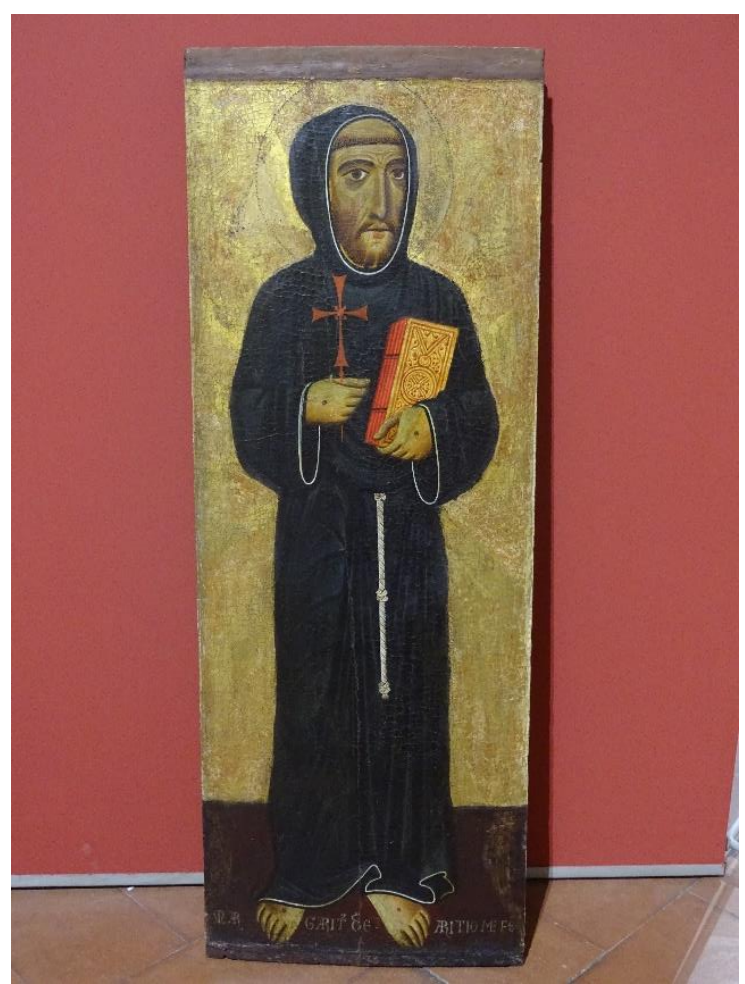

Photo by author, permission for use kindly granted by Pierpaolo Mangani, Pinacoteca

Comunale, Castiglion Fiorentino 
Chapter 3 Icons of Francis as Orthodox Exemplar in Opposition to the Cathar Perfecti

Figure 3.1 San Francesco, Benedictine Monastery in Subiaco, Italy

https://commons.wikimedia.org/wiki/File:Stfrancis.jpg.

Figure 3.2 Margarito d'Arezzo and assistant, San Francesco, Galleria e Museo Medievale e Moderno, Arezzo (originally from Sargiano)

https://upload.wikimedia.org/wikipedia/commons/5/59/Margaritone_d\%27arezzo_st_fran cis_arezzo_museum.jpg

Figure 3.3 Margarito d'Arezzo, San Francesco, Vatican Pinacoteca, Rome

https://upload.wikimedia.org/wikipedia/commons/7/7d/Margaritone_d\%27arezzo\%2C_s. francesco\%2C_1270-80_ca..JPG

Figure 3.4 John Chrysostom, mosaic detail from Palatine Chapel, Sicily https://upload.wikimedia.org/wikipedia/commons/thumb/e/eb/Meister_der_Palastkapelle in_Palermo_003.jpg/1200px-Meister_der_Palastkapelle_in_Palermo_003.jpg

Figure 3.5 Attributed to Maestro della Croce Coppo di Marcovaldo, San Francesco, Storie della sua Vita e Miracoli Dopo la Morte (detail, Francis Preaching to a Crowd), Museo Civici di Pistoia

https://upload.wikimedia.org/wikipedia/commons/5/5e/Maestro_della_croce_434_e_mae stro_di_santa_maria_primerana\%2C_san_francesco_e_storie_della_sua_vita_\%28dettagl io\%29\%2C_pistoia\%2C_museo_civico.jpg 
Figure 3.6 Sano di Pietro, Predicación de San Bernardino por Sano di Pietro (detail). Museo dell'Opera del Duomo, Siena. c. 1540.

https://commons.wikimedia.org/wiki/File:San_Bernardino_Sano_di_Pietro_02.JPG

Figure 3.7 Bonaventura Berlinghieri, San Francesco e Storie della sua Vita (detail, Stigmatization), Chiesa di San Francesco, Pescia

https://upload.wikimedia.org/wikipedia/commons/1/1e/Bonaventura_Berlingieri_St_Francis_of_Assisi.jpg

Figure 3.8 Maestro del San Francesco Bardi (possibly Coppo di Marcovaldo, San Francesco e Venti Storie della sua Vita (detail, Stigmatization), Basilica di Santa Croce, Cappella Bardi, Florence

https://upload.wikimedia.org/wikipedia/commons/b/b4/Master_of_the_bardi_saint_franci s_.St._Francis_and_scenes_from_his_life_13_cent_Santa_croce.jpg

Figure 3.9 Attributed to Maestro della Croce Coppo di Marcovaldo, San Francesco, Storie della sua Vita e Miracoli Dopo la Morte (detail, Stigmatization), Museo Civici di Pistoia

https://upload.wikimedia.org/wikipedia/commons/5/5e/Maestro_della_croce_434_e_mae stro_di_santa_maria_primerana\%2C_san_francesco_e_storie_della_sua_vita_\%28dettagl io\%29\%2C_pistoia\%2C_museo_civico.jpg

Figure 3.10 Maestro del San Francesco di Orte, San Francesco e Quattro Scene (detail, Stigmatization), Museo d'Arte Sacra di Orte

https://media.gettyimages.com/photos/st-francis-and-stories-of-his-life-by-an-unknownartist-from-orte-picture-id148277273?s=2048x2048 
Figure 3.11 Guido di Graziano, San Francesco e Storie della sua Vita (detail, Stigmatization), Pinacoteca Nazionale di Siena

https://upload.wikimedia.org/wikipedia/commons/5/56/Guido_di_graziano\%2C_san_fran cesco_e_storie_della_sua_vita\%2C_1278-1302_ca..JPG

Figure 3.12 St. Francis Master, San Francesco, Museo della Porziuncola, Santa Maria degli Angeli, Assisi.

The picture has been kindly granted by the Portiuncula Museum.

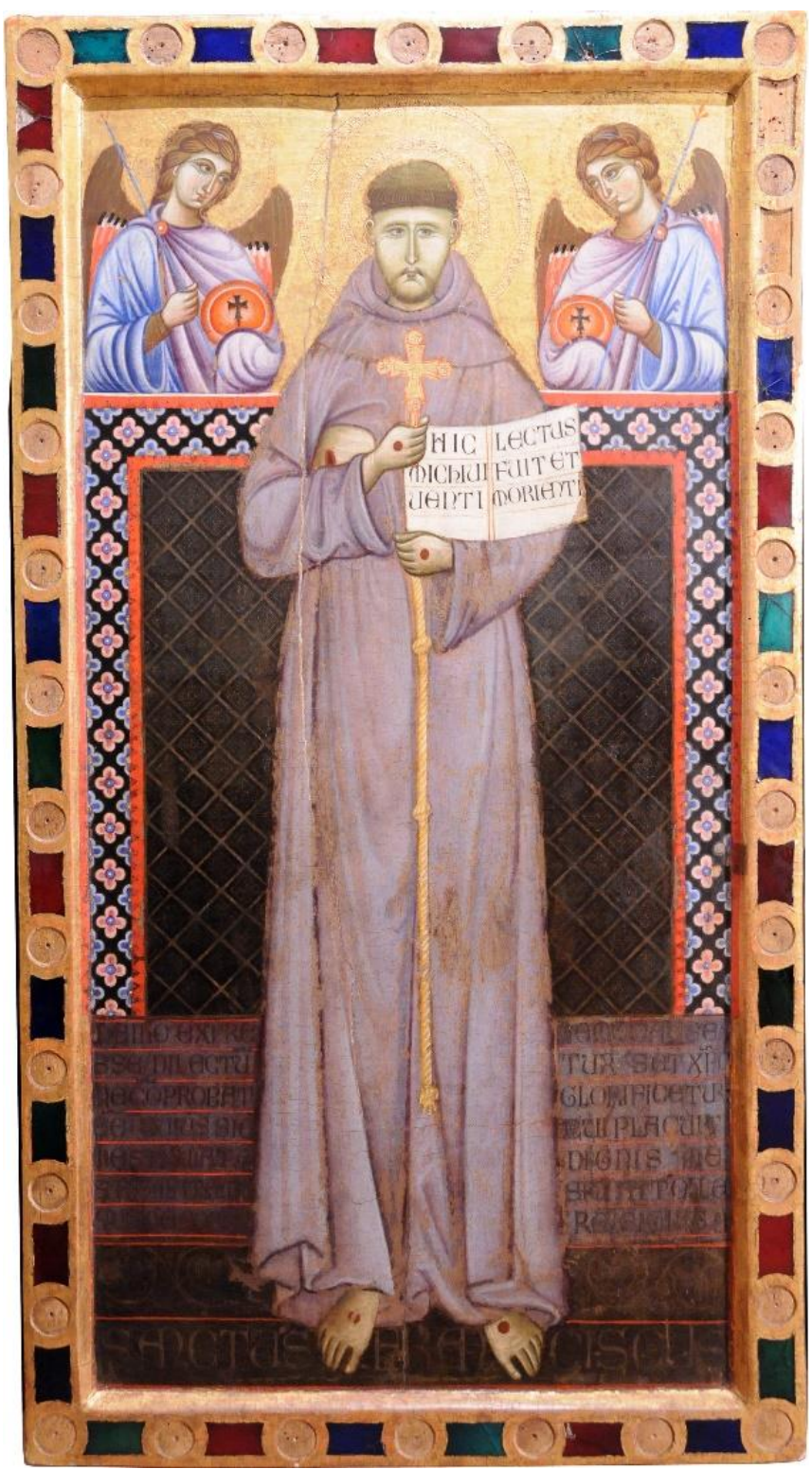


Figure 3.13 Anonymous Roman Artist, Saint François d'Assise, Musée du Louvre, Paris

cartelfr.louvre.fr/cartelfr/visite?srv=obj_view_obj\&objet=cartel_1228_1375_p0003854.0 01.jpg_obj.html\&flag=true

Figure 3.14 Cimabue, San Francesco, Assisi, Museo della Porziuncola, Santa Maria degli Angeli.

The picture has been kindly granted by the Portiuncula Museum.

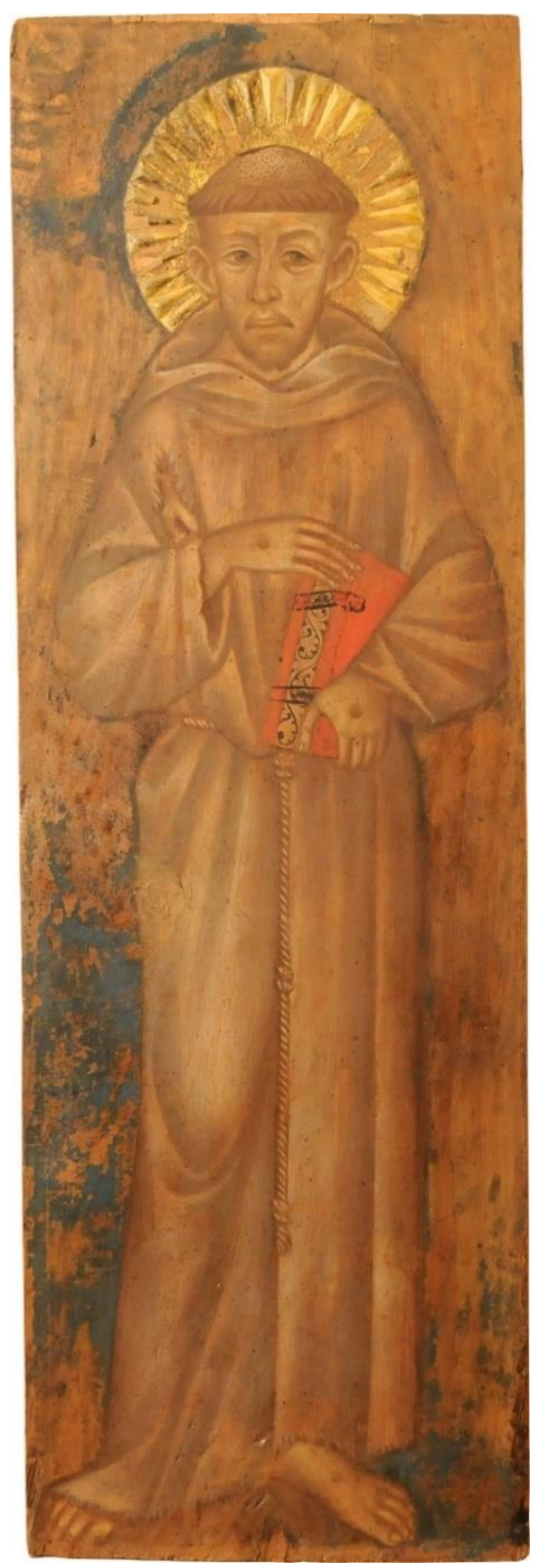


Chapter 4 Vita Dossals as a Response to the Cathar Heresy

Figure 4.1 Reconciliation of a Cathar, from San Francesco e Quattro Scene, Museo d'Arte Sacra di Orte

https://media.gettyimages.com/photos/st-francis-and-stories-of-his-life-by-an-unknownartist-from-orte-picture-id148277273?s=2048x2048

Figure 4.2 San Francesco e Quattro Scene, Museo d'Arte Sacra di Orte https://media.gettyimages.com/photos/st-francis-and-stories-of-his-life-by-an-unknownartist-from-orte-picture-id148277273?s=2048×2048

Figure 4.3 Reconciliation with an Icon, from San Francesco e Quattro Scene, Museo d'Arte Sacra di Orte

https://media.gettyimages.com/photos/st-francis-and-stories-of-his-life-by-an-unknownartist-from-orte-picture-id148277273?s=2048×2048

Figure 4.4 Bonaventura Berlinghieri. San Francesco e Storie della sua Vita, Chiesa di San Francesco, Pescia

https://upload.wikimedia.org/wikipedia/commons/1/1e/Bonaventura_Berlingieri_St_Francis_of_Assisi.jpg

Figure 4.5 Healing of the Girl with the Twisted Neck, detail from San Francesco e Storie della sua Vita, Chiesa di San Francesco, Pescia https://upload.wikimedia.org/wikipedia/commons/1/1e/Bonaventura_Berlingieri__St_Francis_of_Assisi.jpg

Figure 4.6 Healing of the Girl with the Twisted Neck and Exorcism, detail from San Francesco e Venti Storie della sua Vita, Basilica di Santa Croce, Cappella Bardi, Florence 
https://upload.wikimedia.org/wikipedia/commons/b/b4/Master_of the bardi_saint_franci s_.STt._Francis_and_scenes_from his_life_13 cent_Santa_croce.jpg

Figure 4.7 Healing of the Girl with the Twisted Neck, from San Francesco, Storie della sua Vita e Miracoli Dopo la Morte, Museo Civici di Pistoia

https://upload.wikimedia.org/wikipedia/commons/5/5e/Maestro_della_croce_434_e_mae stro_di_santa_maria_primerana\%2C_san_francesco_e_storie_della_sua_vita_\%28dettagl io\%29\%2C_pistoia\%2C_museo_civico.jpg

Figure 4.8 Healing of the Girl with the Twisted Neck, detail from San Francesco e Quattro Miracoli, Museo del Tesoro della Basilica di San Francesco, Assisi

https://upload.wikimedia.org/wikipedia/commons/4/4e/Frama_AssSC040.JPG

Figure 4.9 Healing of the Girl with the Twisted Neck, from San Francesco e Quattro Miracoli Post-Mortem, Vatican Pinacoteca, Rome

https://it.wikipedia.org/wiki/San_Francesco_e_quattro_miracoli_postmortem\#/media/File:Giunta_Pisano._St_Francisc.1260-70._Vatican._Pinacoteca.jpg

Figure 4.10 Healing of the Girl with the Twisted Neck, detail from Dossale con San Francesco e Sei Miracoli, Museo Nazionale di San Matteo, Pisa

https://it.wikipedia.org/wiki/Dossale_di_San_Francesco_e_sei_miracoli\#/media/File:Giu nta_Pisano._St._Francisc_and_six_stories_from_his_life._Ca._1250-

60._Museo_San_Matteo,_Pisa.jpg

Figure 4.11 Healing of Bartholomew of Narni, detail from San Francesco e Storie della sua Vita, Chiesa di San Francesco, Pescia 
https://upload.wikimedia.org/wikipedia/commons/1/1e/Bonaventura_Berlingieri_-

_St_Francis_of_Assisi.jpg

Figure 4.12 Healing of Bartholomew of Narni, detail from San Francesco e Venti Storie della sua Vita, Basilica di Santa Croce, Cappella Bardi, Florence

https://upload.wikimedia.org/wikipedia/commons/b/b4/Master_of_the_bardi_saint_franci s_.St._Francis_and_scenes_from_his_life_13_cent_Santa_croce.jpg

Figure 4.13 Healing of Bartholomew of Narni, from San Francesco, Storie della sua Vita e Miracoli Dopo la Morte, Museo Civici di Pistoia

https://upload.wikimedia.org/wikipedia/commons/5/5e/Maestro_della_croce_434_e_mae stro_di_santa_maria_primerana\%2C_san_francesco_e_storie_della_sua_vita_\%28dettagl io\%29\%2C_pistoia\%2C_museo_civico.jpg

Figure 4.14 Healing of Bartholomew of Narni, detail from San Francesco e Quattro Miracoli, Museo del Tesoro della Basilica di San Francesco, Assisi

https://upload.wikimedia.org/wikipedia/commons/4/4e/Frama_AssSC040.JPG

Figure 4.15 Healing of Bartholomew of Narni, from San Francesco $e$ Quattro Miracoli Post-Mortem, Vatican Pinacoteca, Rome

https://it.wikipedia.org/wiki/San_Francesco_e_quattro_miracoli_postmortem\#/media/File:Giunta_Pisano._St_Francisc.1260-70._Vatican._Pinacoteca.jpg

Figure 4.16 Healing of Bartholomew of Narni, detail from Dossale con San Francesco e Sei Miracoli, Museo Nazionale di San Matteo, Pisa 
https://it.wikipedia.org/wiki/Dossale_di_San_Francesco_e_sei_miracoli\#/media/File:Giu nta_Pisano._St._Francisc_and_six_stories_from_his_life._Ca._1250-

60._Museo_San_Matteo,_Pisa.jpg

Figure 4.17 Healing of Child's Eyes on the Feast of St. Francis, from Dossale con San Francesco e Sei Miracoli, Museo Nazionale di San Matteo, Pisa

https://it.wikipedia.org/wiki/Dossale_di_San_Francesco_e_sei_miracoli\#/media/File:Giu nta_Pisano._St._Francisc_and_six_stories_from_his_life._Ca._1250-

60._Museo_San_Matteo,_Pisa.jpg

Figure 4.18 Nativity at Greccio, detail from San Francesco e Venti Storie della sua Vita, Basilica di Santa Croce, Cappella Bardi, Florence

https://upload.wikimedia.org/wikipedia/commons/b/b4/Master_of_the_bardi_saint_franci $\underline{\text { s_.SSt._Francis_and_scenes_from_his_life_13_cent_Santa_croce.jpg }}$

Figure 4.19 Nativity at Greccio, from San Francesco e Storie della sua Vita, Pinacoteca Nazionale di Siena

https://upload.wikimedia.org/wikipedia/commons/5/56/Guido_di_graziano\%2C_san_francesco_e_storie_d ella_sua vita\%2C $1278-1302$ ca..JPG

Figure 4.20 Sermon to the Birds, detail from San Francesco e Storie della sua Vita, Chiesa di San Francesco, Pescia

https://upload.wikimedia.org/wikipedia/commons/1/1e/Bonaventura_Berlingieri__St_Francis_of_Assisi.jpg

Figure 4.21 Sermon to the Birds, detail from San Francesco e Venti Storie della sua Vita, Basilica di Santa Croce, Cappella Bardi, Florence

https://upload.wikimedia.org/wikipedia/commons/b/b4/Master_of_the_bardi_saint_franci s_.St._Francis_and_scenes_from_his_life_13_cent_Santa_croce.jpg 
Figure 4.22 Sermon to the Birds, from San Francesco e Quattro Scene, Museo d'Arte Sacra di Orte

https://media.gettyimages.com/photos/st-francis-and-stories-of-his-life-by-an-unknownartist-from-orte-picture-id148277273?s=2048×2048

Figure 4.23 Sermon to the Birds, from San Francesco e Storie della sua Vita, Pinacoteca Nazionale di Siena

https://upload.wikimedia.org/wikipedia/commons/5/56/Guido_di_graziano\%2C_san_francesco_e_storie_d ella sua_vita\%2C 1278-1302_ca..JPG

Figure 4.24 Francis Ransoms the Lambs from Among the Goats, detail from San Francesco e Venti Storie della sua Vita, Basilica di Santa Croce, Cappella Bardi, Florence

https://upload.wikimedia.org/wikipedia/commons/b/b4/Master_of the bardi_saint_franci s_._St._Francis_and_scenes_from_his_life_13_cent_Santa_croce.jpg

Figure 4.25 Francis Exchanges his Cloak for Two Lambs a Shepherd is Carrying to Slaughter, detail from San Francesco e Venti Storie della sua Vita, Basilica di Santa Croce, Cappella Bardi, Florence

https://upload.wikimedia.org/wikipedia/commons/b/b4/Master_of_the_bardi_saint_franci s_.St._Francis_and_scenes_from_his_life_13_cent_Santa_croce.jpg

Figure 4.26 Stigmatization, detail from San Francesco e Storie della sua Vita, Pinacoteca Nazionale di Siena

https://upload.wikimedia.org/wikipedia/commons/5/56/Guido_di_graziano\%2C_san_fran cesco_e_storie_della_sua_vita\%2C_1278-1302_ca..JPG 
Figure 4.27 Assisi townscape, detail from San Francesco e Quattro Miracoli, Museo del Tesoro della Basilica di San Francesco, Assisi

https://upload.wikimedia.org/wikipedia/commons/4/4e/Frama_AssSC040.JPG

Figure 4.28 Altars in the Exorcism and Healing of Pilgrims scenes, detail from San Francesco e Quattro Miracoli, Museo del Tesoro della Basilica di San Francesco, Assisi

https://upload.wikimedia.org/wikipedia/commons/4/4e/Frama_AssSC040.JPG

Figure 4.29 Altar in the Lower Basilica of San Francesco, Assisi https://commons.wikimedia.org/wiki/File:\%22_Assisi_\%22_0001.jpg

Chapter 5 Countering Heresy through the Theology and Materiality of the Painted-Panel Crucifixes

Figure 5.1 Cross of Maestro Guglielmo, Cathedral of Sarzana, Italy

https://it.wikipedia.org/wiki/Croce_di_Mastro_Guglielmo\#/media/File:Crusifix._Master_ Guglielmo..jpg,

Figure 5.2 Cross of Maestro Guglielmo (in situ), Cathedral of Sarzana, Italy

https://en.wikipedia.org/wiki/Sarzana_Cathedral\#/media/File:Sarzana-cattedralealtare4.jpg

Figure 5.3 Cross of San Damiano in the Basilica of Santa Chiara, Assisi, Italy 
https://upload.wikimedia.org/wikipedia/commons/3/31/Kruis_san_damiano.gif

Figure 5.4 Theoretical Format of lower part of Giunta Pisano's Crucifix for the Basilica di San Francesco

Based on his example from the Porziuncola, the crucifix by the Maestro di Santa Chiara in the Basilica di Santa Chiara, and the oil painting Brother Elias before the Crucifix, Santa Maria della Concezione, Rome, by Francesco Providoni

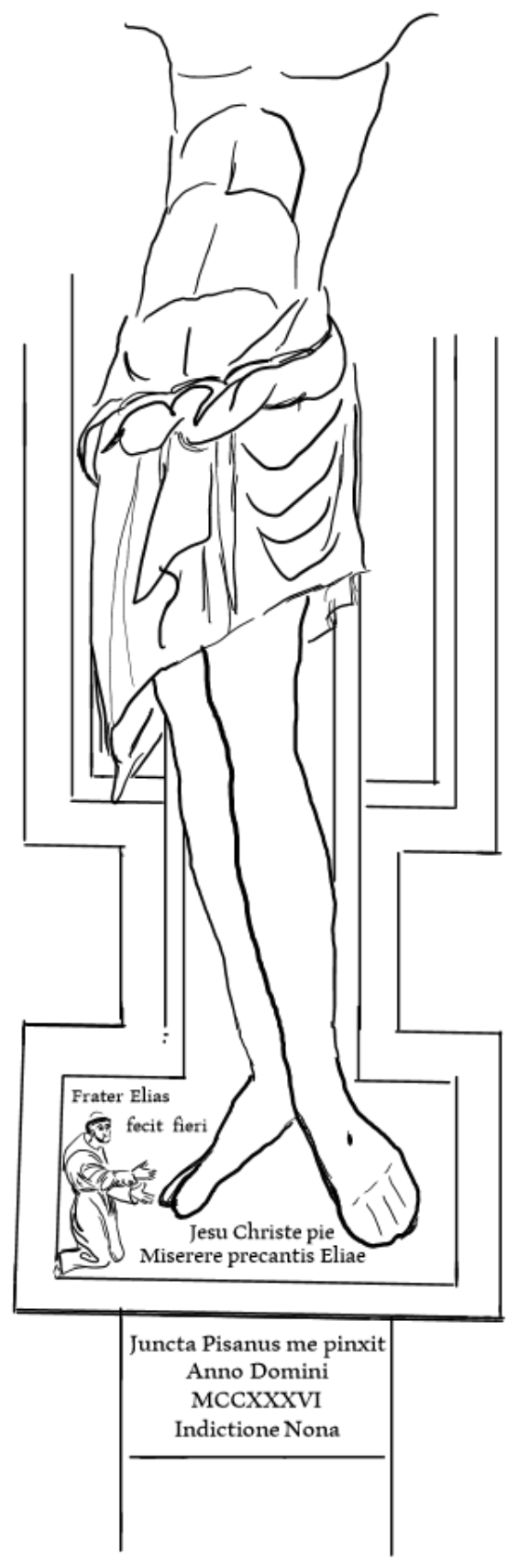


Figure 5.5 Giunta Pisano, Crucifix of Santa Maria degli Angeli alla Porziuncola, Assisi

The picture has been kindly granted by the Portiuncula Museum.

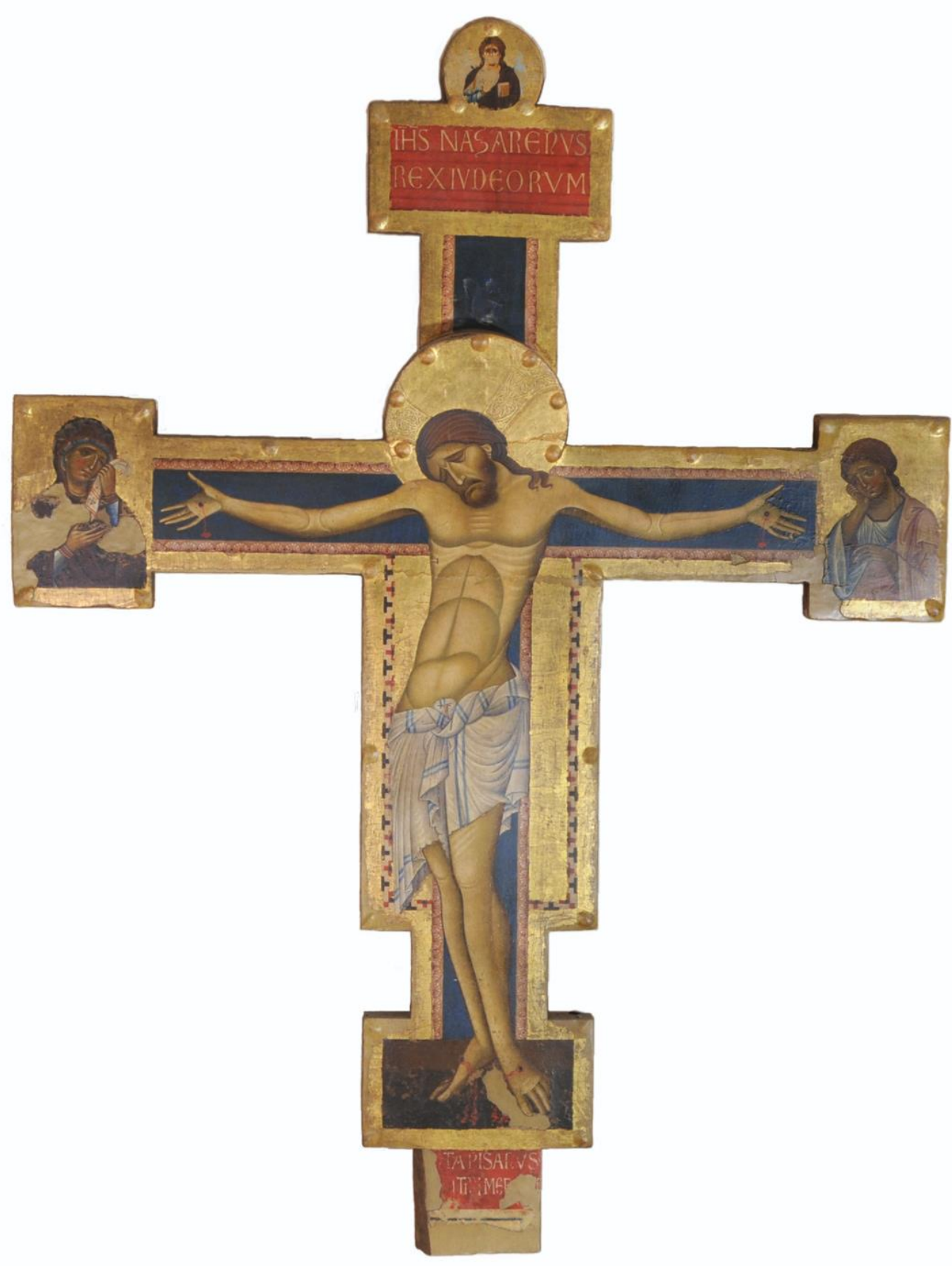


Figure 5.6 Verification of the Stigmata, Upper Basilica of San Francesco, Assisi

https://upload.wikimedia.org/wikipedia/commons/a/ae/Giotto___Legend_of_St_Francis_-22-__- Verification_of the Stigmata.jpg

Figure 5.7 Nativity at Greccio, Upper Basilica of San Francesco, Assisi https://upload.wikimedia.org/wikipedia/commons/9/9a/Giotto_LLegend_of_St_Francis___-13____Institution_of_the_Crib_at_Greccio.jpg

Figure 5.8 Crucifixion wall painting in the Church of Nemanja in the Studenica Monastery

https://en.wikipedia.org/wiki/Studenica_Monastery\#/media/File:Studenica_raspece.jpg

Figure 5.9 Crucifixion wall painting in the Church of the Resurrection in the Žiča Monastery

http://www.panacomp.net/zica-monastery-serbia/

Figure 5.10 The Entry into Jerusalem, the Crucifixion, and the Harrowing of Hell, from the Dodecaorton Epistyle, Chapel of Constantine and Helena, Monastery of St. Catherine, Mount Sinai, Egypt

https://www.flickr.com/photos/28433765@N07/7703476326/

Figure 5.11 The Ascension, Pentecost, and Dormition, from the Dodecaorton Epistyle, Chapel of Constantine and Helena, Monastery of St. Catherine, Mount Sinai, Egypt

https://www.flickr.com/photos/28433765@N07/7703477088/ 
Figure 5.12 Baptism of Christ, the Transfiguration, and the Raising of Lazarus, from the Dodecaorton Epistyle, Chapel of St. George, Monastery of St. Catherine, Mount Sinai, Egypt

https://www.flickr.com/photos/28433765@N07/7703475306/

Figure 5.13 Annunciation, the Nativity, and Jesus' Presentation in the Temple, from the Dodecaorton Epistyle, Chapel of St. George, Monastery of St. Catherine, Mount Sinai, Egypt

https://www.flickr.com/photos/28433765@N07/7703476326/

Figure 5.14 Crocifisso con San Francesco, Basilica di San Francesco, Arezzo, Italy by a Follower of Master of Santa Chiara

https://it.wikipedia.org/wiki/Storie_della_Vera_Croce\#/media/File:Arezzo_s. francesco,_storie_della_vera_croce.jpg

Figure 5.15 Basilica di San Francesco (interior), Arezzo

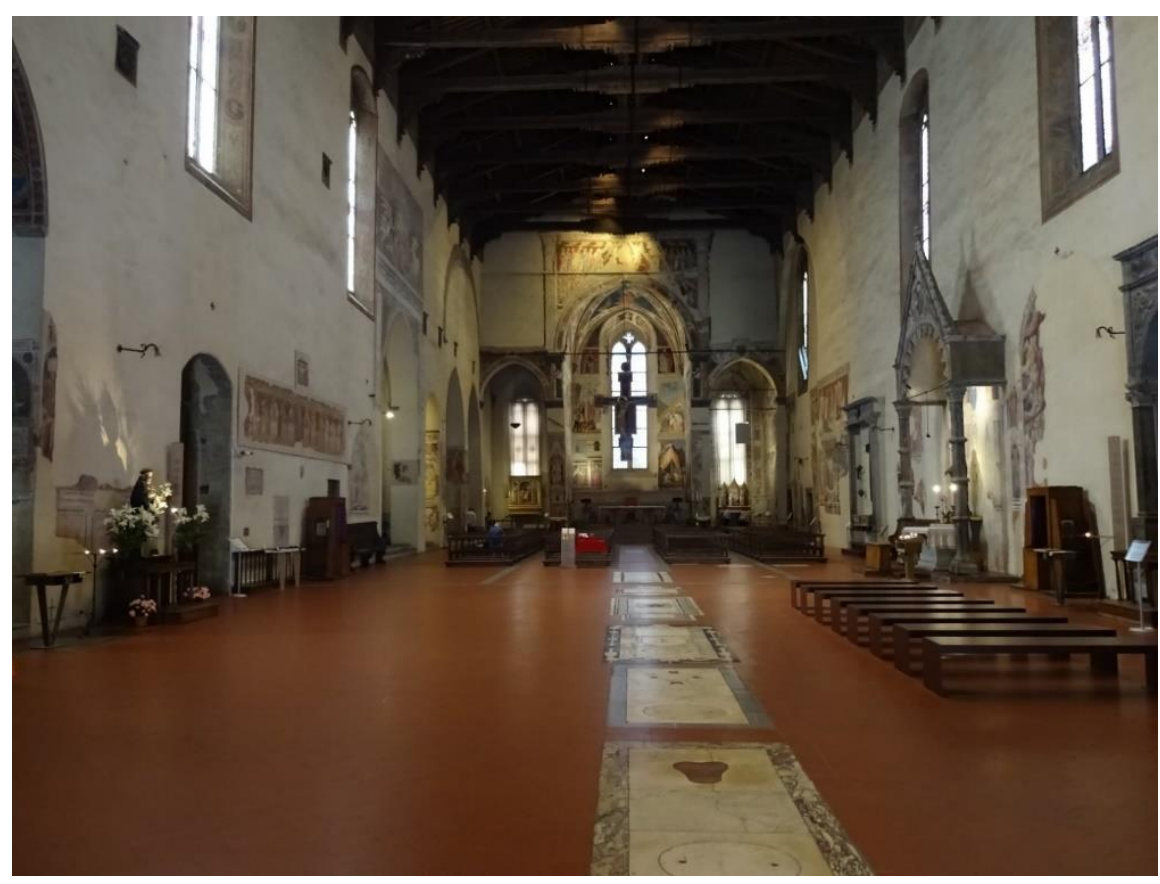

Photo by author 
Figure 5.16 Crocifisso con San Francesco (detail), Basilica di San Francesco (interior), Arezzo

https://it.wikipedia.org/wiki/Storie_della_Vera_Croce\#/media/File:Arezzo__s._francesco,_storie_della_vera_croce.jpg

Figure 5.17 Drawing based on Kurt Weitzman's photo of Cod. 1186, 79r with examples of early Christian illustrations of the Temple Curtain
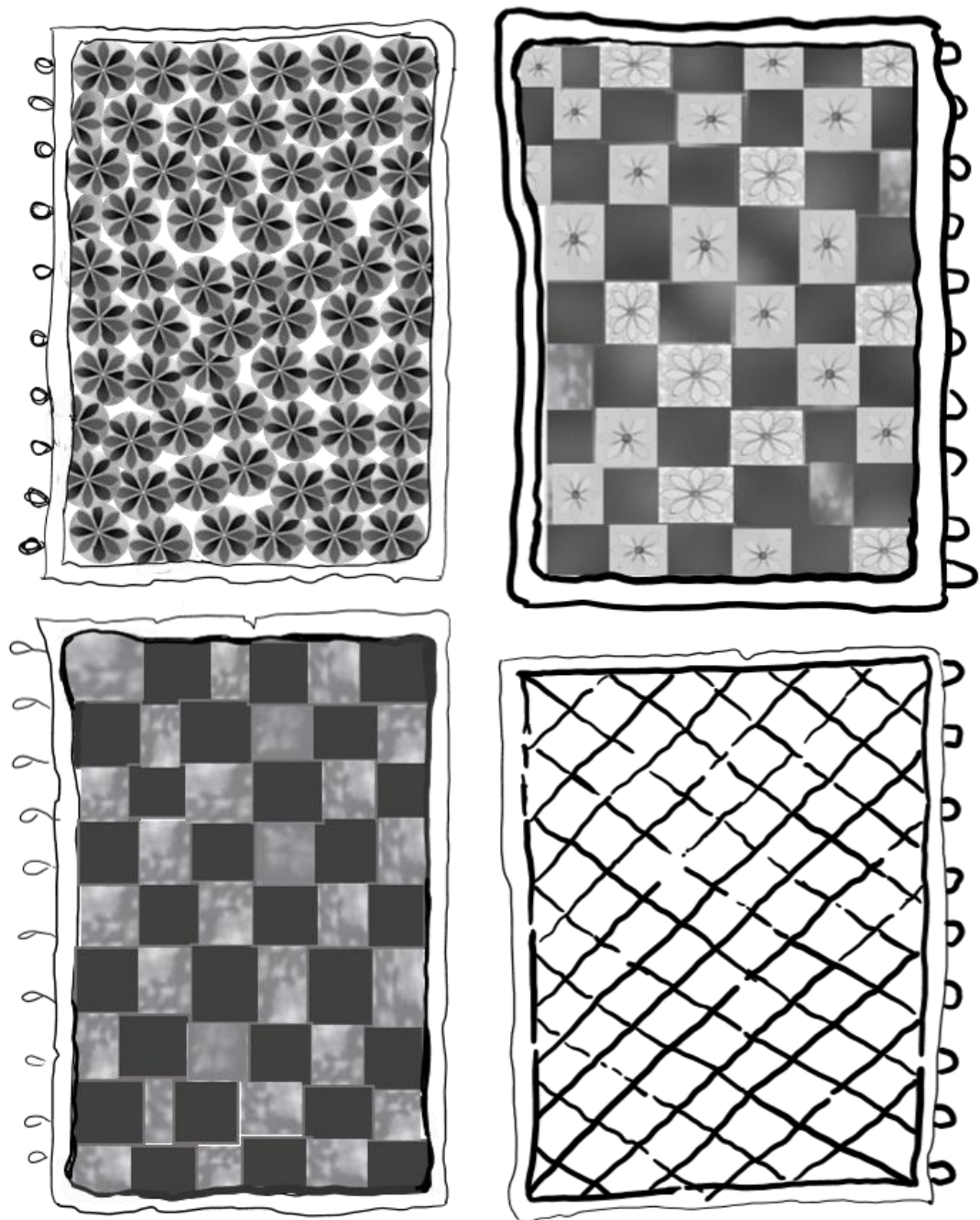

Drawing by author based on Weitzman's photo ${ }^{612}$

${ }^{612}$ Kessler, Spiritual Seeing, 58. 
Figure 5.18 Examples of Apron Decoration from the Crucifixes in Arezzo, Perugia, Spello

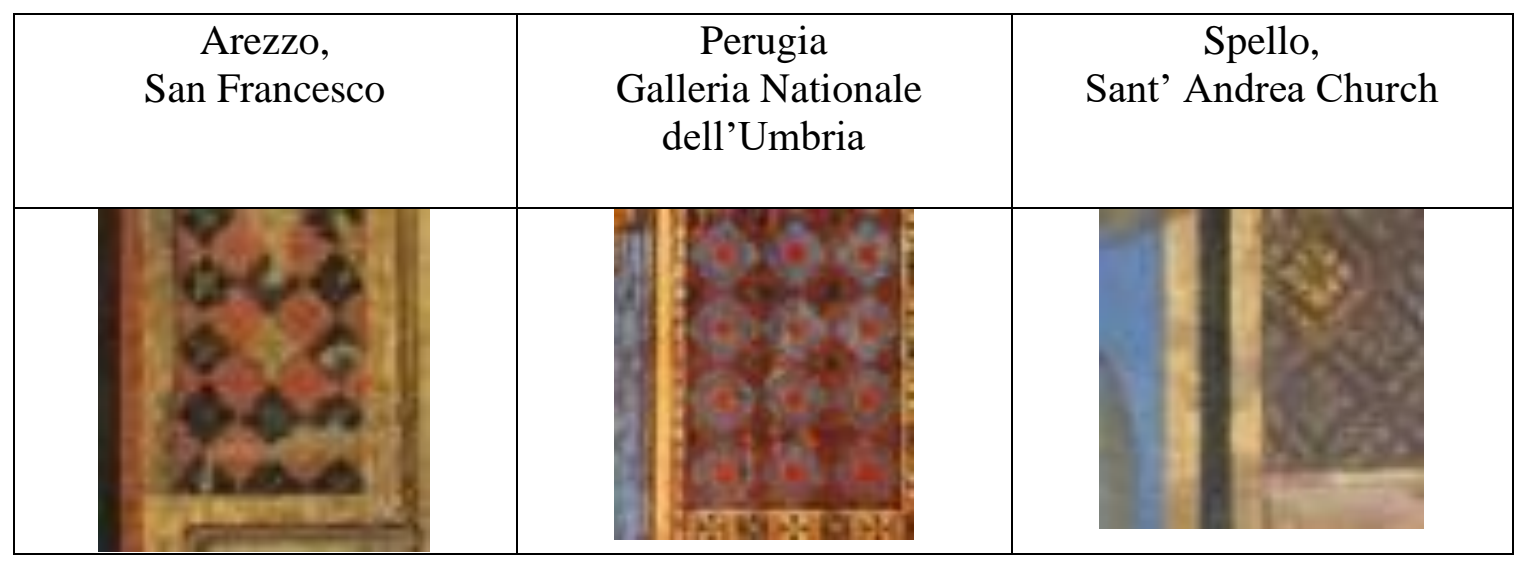

Figure 5.19 Maestro di San Francesco, Crocifisso con San Francesco, Galleria Nationale dell'Umbria, Perugia

https://it.wikipedia.org/wiki/Crocifisso_di_Perugia_del_Maestro_di_San_Francesco\#/me dia/File:Crusifix_Maestro_di_San_Francesco._Perugia.jpg

Figure 5.20 Expressionist Master of Santa Chiara, Cristo Crocifisso, Chiesa Museo di San Francesco, Montefalco

https://www.museodimontefalco.it/upload/mediagallery-gallery-Big-24.jpg

Figure 5.21 Maestro di San Francesco, Crocifisso con San Francesco (suppedaneo detail), Galleria Nationale dell'Umbria, Perugia

http://casavacanze.poderesantapia.com/arte/maestrodisanfrancesco/maestrodisanfrancesc ocrocifissoperugia.htm\#due

Figure 5.22 Expressionist Master of Santa Chiara or Maestro UmbroGiottesco, Crocifisso Tempera su tavola, Chiesa di Sant' Andrea, Spello

https://upload.wikimedia.org/wikipedia/commons/0/00/Spello\%2C_s._andrea\%2C_crocif isso_giottesco\%2C_inizio_trecento\%2C_02.JPG 


\section{Appendices}

\section{Appendix 1 Fourth Lateran Council: Canon 3 on Heresy (1215)}

We excommunicate and anathematize every heresy that raises against the holy, orthodox and Catholic faith which we have above explained; condemning all heretics under whatever names they may be known, for while they have different faces they are nevertheless bound to each other by their tails, since in all of them vanity is a common element. Those condemned, being handed over to the secular rulers of their bailiffs, let them be abandoned, to be punished with due justice, clerics being first degraded from their orders. As to the property of the condemned, if they are laymen, let it be confiscated; if clerics, let it be applied to the churches from which they received revenues. But those who are only suspected, due consideration being given to the nature of the suspicion and the character of the person, unless they prove their innocence by a proper defense, let them be anathematized and avoided by all until they have made suitable satisfaction; but if they have been under excommunication for one year, then let them be condemned as heretics. Secular authorities, whatever office they may hold, shall be admonished and induced and if necessary compelled by ecclesiastical censure, that as they wish to be esteemed and numbered among the faithful, so for the defense of the faith they ought publicly to take an oath that they will strive in good faith and to the best of their ability to exterminate in the territories subject to their jurisdiction all heretics pointed out by the Church; so that whenever anyone shall have assumed authority, whether spiritual or temporal, let him be bound to confirm this decree by oath. But if a temporal ruler, after having been requested and admonished by the Church, should neglect to cleanse his territory of this heretical foulness, let him be excommunicated by the metropolitan and the other bishops of the province. If he refuses to make satisfaction within a year, let the matter be made known to the supreme pontiff, that he may declare the ruler's vassals absolved from their allegiance and may offer the territory to be ruled by lay Catholics, who on the extermination of the heretics may possess it without hindrance and preserve it in the purity of faith; the right, however, of the chief ruler is to be respected as long as he offers no obstacle in this matter and permits freedom of action. The same law is to be observed in regard to those who have no chief rulers (that is, are independent). Catholics who have girded themselves with the cross for the extermination of the heretics, shall enjoy the indulgences and privileges granted to those who go in defense of the Holy Land. ${ }^{613}$

613 "Fourth Lateran Council: Canon 3 on Heresy, Internet History Sourcebooks Project," accessed February 26, 2016, https://legacy.fordham.edu/halsall/source/lat4-c3.asp. 


\section{Appendix 2 Relevant text of On the Reduction of the Arts to Theology, Bonaventure}

11. By the same process of reasoning is Divine Wisdom to be found in the illumination of the mechanical arts, the sole purpose of which is the production of artifacts. In this illumination we can see the eternal generation and Incarnation of the Word, the pattern of human life, and the union of the soul with God. And this is true if we consider the production, the effect, and the fruit of a work, or if we consider the skill of the artist, the quality of the effect produced, and the utility of the product derived therefrom.

12. If we consider the production, we shall see that the work of art proceeds from the artificer according to a similitude existing in his mind; this pattern or model the artificer studies carefully before he produces and then he produces as he has predetermined. The artificer, moreover, produces an exterior work bearing the closest possible resemblance to the interior exemplar, and if it were in his power to produce an effect which would know and love him, this he would assuredly do; and if that effect could know its maker, it would be by means of the similitude according to which it came from the hands of the artificer; and if the eyes of the understanding were so darkened that it could not elevate itself to things above itself in order to bring itself to a knowledge of its maker, it would be necessary for the similitude according to which the effect was produced to lower itself even to that nature which the effect could grasp and know. In like manner, understand that no creature has proceeded from the Most High Creator except through the Eternal Word, "in Whom He ordered all things," and by which Word He produced creatures bearing not only the nature of His vestige but also of His image so that through knowledge they might become like unto Him. And since by sin the rational creature had dimmed the eye of contemplation, it was most fitting that the Eternal and Invisible should become visible and take flesh that He might lead us back to the Father. Indeed, this is what is related in the fourteenth chapter of Saint John: "No one comes to the Father but through Me," and in the eleventh chapter of Saint Matthew: "No one knows the Son except the Father; nor does anyone know the Father except the Son, and him to whom the Son chooses to reveal him." For that reason, then, it is said, "the Word was made flesh." Therefore, considering the illumination of mechanical art as regards the production of the work, we shall see therein the Word begotten and made incarnate, that is, the Divinity and the Humanity and the integrity of all faith.

13. If we consider the effect, we shall see therein the pattern of human life, for every artificer, indeed, aims to produce a work that is beautiful, useful, and enduring, and only when it possesses these three qualities is the work highly valued and acceptable.

Corresponding to the above-mentioned qualities, in the pattern of life there must be found three elements: "knowledge, will, and unaltering and persevering toil." Knowledge renders the work beautiful; the will renders it useful; perseverance renders it lasting. The first resides in the rational, the second in the concupiscible, and the third in the irascible appetite. 
14. If we consider the fruit, we shall find therein the union of the soul with God, for every artificer who fashions a work does so that he may derive praise, benefit, or delight therefrom--a threefold purpose which corresponds to the three formal objects of the appetites: namely, a noble good, a useful good, and an agreeable good. It was for this threefold reason that God made the soul rational, namely, that of its own accord, it might praise Him, serve Him, find delight in Him, and be at rest; and this takes place through charity. "He who abides in it, abides in God, and God in him," in such a way that there is found therein a kind of wondrous union and from that union comes a wondrous delight, for in the Book of Proverbs it is written, "My delights were to be with the children of men." Behold how the illumination of mechanical art is the path to the illumination of Sacred Scripture. There is nothing therein which does not bespeak true wisdom and for this reason Sacred Scripture quite rightly makes frequent use of such similitudes. ${ }^{614}$

${ }^{614}$ Also known as On the Retracing of the Arts to Theology. Bonaventure, De Reductione Artium Ad Theologiam: A Commentary with an Introduction and Translation by Sister Emma Thérèse Healy. (Saint Bonaventure, N.Y.: St. Bonaventure University, 1955), 31-35, https://archive.org/details/dereductionearti0001bona. 


\title{
Appendix 3 The Manger He Made in Celebration of the Lord's Birthday, Thomas of Celano, Vita Prima Chapter XXX
}

\author{
${ }^{84}$ His highest aim, foremost desire, and greatest intention \\ was to pay heed to the holy gospel in all things and through all things, \\ to follow the teaching of our Lord Jesus Christ \\ and to retrace His footsteps completely \\ with all vigilance and all zeal, \\ all the desire of his soul \\ and all the fervor of his heart. \\ Francis used to recall with regular meditation the words of Christ \\ and recollect His deeds with most attentive perception. \\ Indeed, so thoroughly did the humility of the Incarnation \\ and the charity of the Passion \\ occupy his memory \\ that he scarcely wanted to think of anything else.
}

We should note then, as matter worthy of memory and something to be recalled with reverence, what he did, three years prior to his death, at the town of Greccio, on the birthday of our Lord Jesus Christ. There was a certain man in that area named John who had a good reputation but an even better manner of life. Blessed Francis loved him with special affection, since, despite being a noble in the land and very honored in human society, he had trampled the nobility of the flesh under his feet and pursued instead the nobility of the spirit. As usual, blessed Francis had John summoned to him some fifteen days prior to the birthday of the Lord. "If you desire to celebrate the coming feast of the Lord together at Greccio," he said to him, "hurry before me and carefully make ready ${ }^{\text {Prv }}$ 24:27 the things I tell you. For I wish to enact the memory of that babe who was born in Bethlehem: to see as much as is possible with my own bodily eyes the discomfort of his infant needs, how he lay in a manger, ${ }^{\text {Lk } 2: 7}$ and how, with an ox and an ass standing by, he rested on hay." Once the good and faithful man had heard Francis's words, he ran quickly ${ }^{\mathrm{Jn} 20: 4}$ and prepared in that place all the things that the holy man had requested.

${ }^{85}$ Finally, the day of joy has drawn near, the time of exultation has come.

From many different places the brethren have been called.

As they could, the men and women of that land with exultant hearts prepare candles and torches to light up that night whose shining star has enlightened every day and year.

Finally, the holy man of God comes and, finding all things prepared, he saw them and was glad. Jn 8:56

Indeed, the manger is prepared, the hay is carried in, the ox and the ass are led to the spot. 
There simplicity is given a place of honor,

poverty is exalted,

humility is commended,

and out of Greccio is made a new Bethlehem.

The night is lit up like day, Ps 139:12 [Vulgate, Ps 138:12]

delighting both man and beast.

The people arrive, ecstatic at this new mystery of new joy.

The forest amplifies the cries

and the boulders echo back the joyful crowd.

The brothers sing, giving God due praise,

and the whole night abounds with jubilation.

The holy man of God ${ }^{\text {Mk 1:24 }}$ stands before the manger,

filled with heartfelt sighs,

contrite in his piety,

and overcome with wondrous joy.

Over the manger the solemnities of the Mass are celebrated and the priest enjoys a new consolation.

${ }^{86}$ The holy man of God is dressed in the vestments of the Levites, since he was a Levite, and with full voice sings the holy gospel. Here is his voice: a powerful voice, a pleasant voice, $\mathrm{Sg}$ 2:14 a clear voice, a musical voice, inviting all to the highest of gifts. Then he preaches to the people standing around him and pours forth sweet honey about the birth of the poor King and the poor city of Bethlehem. Moreover, burning with excessive love, he often calls Christ the "babe from Bethlehem" whenever he means to call Him Jesus.

Saying the word "Bethlehem" in the manner of a bleating sheep, he fills his whole mouth with sound but even more with sweet affection. He seems to lick his lips whenever he uses the expressions "Jesus" or "babe from Bethlehem," tasting the word on his happy palate and savoring the sweetness of the word. The gifts of the Almighty are multiplied there and a virtuous man sees a wondrous vision. For the man saw a little child lying lifeless in the manger and he saw the holy man of God approach the child and waken him from a deep sleep. Nor is this vision unfitting, since in the hearts of many the child Jesus has been given over to oblivion. ${ }^{\text {Ps } 31: 13 \text { [Vulgate, Ps } 30: 13]}$ Now he is awakened and impressed on their loving memory by His own grace through His holy servant Francis. At length, the night's solemnities draw to a close and everyone went home with joy.

${ }^{87}$ The hay placed in the manger there was preserved afterwards so that, through it, the Lord might restore to health the pack animals and the other animals there, as $\mathrm{He}$ multiplied his holy mercy. It came to pass in the surrounding area that many of the animals, suffering from various diseases, were freed from their illnesses when they ate some of this hay. What is more, women who had been suffering with long and hard labor had an easy delivery after they placed some of this hay upon themselves. Finally, an entire group of people of both sexes obtained much-desired relief from an assortment of afflictions. 
At last, the site of the manger was consecrated as a temple to the Lord. In honor of the most blessed father Francis, an altar was constructed over the manger, and a church was dedicated.

This was done so that where animals once ate the fodder of the hay, Dn 5:21 there humans henceforth for healing of body and soul would eat the flesh of the immaculate and spotless lamb, our Lord Jesus Christ, who gave Himself for us ${ }^{\text {Ti } 2: 14}$ with supreme and indescribable love, who lives and rules with the Father and the Holy Spirit as God, eternally glorious forever and ever.

Amen. Alleluia, Alleluia. ${ }^{615}$

\section{Appendix 4 The Account of the Nativity at Greccio, Bonaventure, Legenda Maior Chapter X}

${ }^{7}$ It happened, three years prior to his death, that he decided to celebrate at the town of Greccio the memory of the birth of the Child Jesus with the greatest possible solemnity, in order to arouse devotion. So that this would not be considered a type of novelty, he petitioned for and obtained permission from the Supreme Pontiff.

He had a manger prepared,

hay carried in and an ox and an ass led to the spot.

The brethren are summoned, the people arrive, the forest amplifies with their cries, and that venerable night is rendered brilliant and solemn

by a multitude of bright lights and by resonant and harmonious hymns of praise.

The man of God stands before the manger, filled with piety, bathed in tears, and overcome with joy.

A solemn Mass is celebrated over the manger, with Francis, a levite of Christ, chanting the holy Gospel.

Then he preaches to the people standing around him about the birth of the poor King,

615 Thomas of Celano and Commission on the Franciscan Intellectual Tradition, "The Life of Saint Francis by Thomas of Celano: Vita Prima," accessed June 5, 2020, https://ranciscantradition.org/francis-of-assisiearly-documents/the-saint/the-life-of-saint-francis-by-thomas-of-celano/698-fa-ed-1-page-254; Thomas et al., The Francis Trilogy of Thomas of Celano: The Life of Saint Frances, The Remembrance of the Desire of a Soul, The Treatise on the Miracles of Saint Francis (Hyde Park, N.Y.: New City Press, 2004), 94-97. 
whom, whenever he means to call him, he called in his tender love, the Babe from Bethlehem.

A certain virtuous and truthful knight, Sir John of Greccio, who had abandoned worldly military activity out of love of Christ and had become an intimate friend of the man of God, claimed that he saw a beautiful little child asleep in that manger whom the blessed father Francis embraced in both of his arms and seemed to wake it from sleep.

Not only does the holiness of the witness

make credible the vision of the devout knight, but also the truth it expresses proves its validity and the subsequent miracles confirm it.

For Francis's example, when considered by the world, is capable of arousing the hearts of those who are sluggish in the faith of Christ.

The hay from the crib was kept by the people and miraculously cured sick animals and drove away different kinds of pestilence. Thus God glorified his servant in every way and demonstrated the efficacy of his holy prayer by the evident signs of wonderful miracles. ${ }^{616}$

${ }^{616}$ Bonaventure and Commission on the Franciscan Intellectual Tradition, "The Life of Blessed Francis: Legenda Maior," accessed June 5, 2020, https://franciscantradition.org/francis-of-assisi-earlydocuments/the-founder/the-legends-and-sermons-about-saint-francis-by-bonaventure-of-bagnoregio/themajor-legend-of-saint-francis/the-life-of-blessed-francis/1699-fa-ed-2-page-610; Bonaventure and Ewert Cousins, Bonaventure: The Soul's Journey into God; The Tree of Life, The Life of St. Francis (New York: Paulist Press, 1978), 278-79. 


\section{Appendix 5 The First Admonition, The Body of Christ, Francis of Assisi}

${ }^{1}$ The Lord Jesus says to his disciples: I am the way, the truth and the life; no one comes to the Father except through me. ${ }^{2}$ If you knew me, you would also know my Father; and from now on, you do know him and have seen him. ${ }^{3}$ Philip says to him: Lord, show us the Father and it will be enough for us. ${ }^{4}$ Jesus says to him: Have I been with you for so long a time and you have not known me? Philip, whoever sees me sees my Father as well. ${ }^{\mathrm{Jn}}$ 14:6-9

${ }^{5}$ The Father dwells in inaccessible light, ${ }^{1}$ Tm 6:16 and God is spirit, ${ }^{\mathrm{Jn}}$ 4:24 and no one has ever seen God. ${ }^{\text {Jn 1:18 }}{ }^{6}$ Therefore He cannot be seen except in the Spirit because it is the Spirit that gives life; the flesh has nothing to offer. ${ }^{\mathrm{In}} 6: 63{ }^{7} \mathrm{But}$ because $\mathrm{He}$ is equal to the Father, the Son is not seen by anyone other than the Father or other than the Holy Spirit.

${ }^{8}$ All those who saw the Lord Jesus according to the humanity, therefore, and did not see and believe according to the Spirit and the Divinity that He is the true Son of God were condemned. ${ }^{9}$ Now in the same way, all those who see the sacrament sanctified by the words of the Lord upon the altar at the hands of the priest in the form of bread and wine, and who do not see and believe according to the Spirit and the Divinity that it is truly the Body and Blood of our Lord Jesus Christ, are condemned.10[This] is affirmed by the Most High Himself Who says:

This is my Body and the Blood of my new covenant [which will be shed for many]; Mk 14:22 ${ }^{11}$ and Whoever eats my flesh and drinks my blood has eternal life. Mk 14:24 ${ }^{12}$ It is the Spirit of the Lord, ${ }^{\text {In } 6: 55}$ therefore, That lives in Its faithful, That receives the Body and Blood of the Lord. ${ }^{13}$ All others who do not share in this same Spirit and presume to receive Him eat and drink judgment on themselves. ${ }^{1 \text { Cor 11:29 }}$

${ }^{14}$ Therefore: children, how long will you be hard of heart? ${ }^{\text {Ps } 4: 3 ~}{ }^{15}$ Why do you not know the truth and believe in the Son of God? ${ }^{\text {In } 9: 35}{ }^{16}$ Behold, each day He humbles Himself as when He came from the royal throne Phil 2:8 into the Virgin's womb; Wis 18:15 ${ }^{17}$ each day He Himself comes to us, appearing humbly; ${ }^{18}$ each day He comes down from the bosom of the Father ${ }^{\text {Jn } 1: 18}$ upon the altar in the hands of a priest.

${ }^{19}$ As He revealed Himself to the holy apostles in true flesh, so He reveals Himself to us now in sacred bread. ${ }^{20}$ And as they saw only His flesh by an insight of their flesh, yet believed that He was God as they contemplated Him with their spiritual eyes, ${ }^{21}$ let us, as we see bread and wine with our bodily eyes, see and firmly believe that they are His most holy Body and Blood living and true. ${ }^{22}$ And in this way the Lord is always with His faithful, as He Himself says: Behold I am with you until the end of the age. ${ }^{617}$

${ }^{617}$ Francis of Assisi and Commission on the Franciscan Intellectual Tradition, "The Admonitions," accessed June 6, 2020, https://franciscantradition.org/francis-of-assisi-early-documents/the-saint/writingsof-francis/the-undated-writings/the-admonitions/144-fa-ed-1-page-128. 


\section{Appendix 6 The Canticle of the Creatures, Francis of Assisi}

Most high, all-powerful, all good, Lord!

All praise is yours, all glory, all honor

And all blessing.

To you alone, Most High, do they belong.

No mortal lips are worthy

To pronounce your name.

All praise be yours, my Lord, through all that you have made, And first my lord Brother Sun,

Who brings the day; and light you give to us through him.

How beautiful is he, how radiant in all his splendor!

Of you, Most High, he bears the likeness.

All praise be yours, my Lord, through Sister Moon and Stars;

In the heavens you have made them, bright

And precious and fair.

All praise be yours, My Lord, through Brothers Wind and Air, And fair and stormy, all the weather's moods,

By which you cherish all that you have made.

All praise be yours, my Lord, through Sister Water,

So useful, lowly, precious and pure.

All praise be yours, my Lord, through Brother Fire, Through whom you brighten up the night.

How beautiful is he, how gay! Full of power and strength.

All praise be yours, my Lord, through Sister Earth, our mother, Who feeds us in her sovereignty and produces

Various fruits with colored flowers and herbs.

All praise be yours, my Lord, through those who grant pardon

For love of you; through those who endure

Sickness and trial.

Happy those who endure in peace,

By you, Most High, they will be crowned.

All praise be yours, my Lord, through Sister Death,

From whose embrace no mortal can escape.

Woe to those who die in mortal sin!

Happy those She finds doing your will!

The second death can do no harm to them. 
Praise and bless my Lord, and give him thanks, And serve him with great humility ${ }^{618}$

${ }^{618}$ Francis of Assisi, St. Francis of Assisi: Writings and Early Biographies : English Omnibus of the Sources for the Life of St. Francis, ed. Marion A Habig (Chicago: Franciscan Herald Press, 1973), 130-31. 


\section{Appendix 7 Sermon to the Birds, Thomas of Celano, Vita Prima Chapter XXI}

"While many were joining the brothers, as already related, the blessed father Francis was travelling through the Spoleto valley. He reached a place near Bevagna, in which a great multitude of birds of different types gathered, including doves, crows, and others commonly called monaclae. When Francis, the most blessed servant of God, saw them, he ran swiftly toward them, leaving his companions on the road. He was a man of great fervor, feeling much sweetness and tenderness even toward lesser, irrational creatures. When he was already very close, seeing that they awaited him, he greeted them in his usual way. He was quite surprised, however, because the birds did not take flight, as they usually do. Filled with great joy, he humbly requested that they listen to the word of God.

Among many other things, he said to them: "My brother birds, you should greatly praise your Creator, and love Him always. He gave you feathers to wear, wings to fly, and whatever you need. God made you noble among His creatures and gave you a home in the purity of the air, so that, though you neither sow nor reap, He nevertheless protects and governs you without your least care." He himself, and those brothers who were with him, used to say that, at these words, the birds rejoiced in a wonderful way according to their nature. They stretched their necks, spread their wings, opened their beaks and looked at him. He passed through their midst, coming and going, touching their heads and bodies with his tunic. Then he blessed them, and having made the sign of the cross, gave them permission to fly off to another place. The blessed father, however, went with his companions along their way rejoicing and giving thanks to God, Whom all creatures revere by their devout confession.

He was already simple by grace, not by nature. After the birds had listened so reverently to the word of God, he began to accuse himself of negligence because he had not preached to them before. From that day on, he carefully exhorted all birds, all animals, all reptiles, and also insensible creatures, to praise and love the Creator, because daily, invoking the name of the Savior, he observed their obedience in his own experience." $" 619$

619 Thomas et al., Francis Trilogy, 74. 


\section{Appendix 8 Sermon to the Birds, Bonaventure, Legenda Maior Chapter XII}

"Through a miraculous revelation of the Spirit, the venerable priest and the virgin dedicated to God came to the same conclusion: that it was the divine good will that the herald of Christ should preach.

When the two brothers returned and told him God's will as they had received it, he rose at once, girded himself ${ }^{\text {Jn 21:7 }}$ and without the slightest delay took to the roads. He went with such fervor to carry out the divine command, just as he ran along so swiftly as if the hand of God were upon him, giving him new strength from heaven. ${ }^{3}$ When he was approaching Bevagna, he came upon a place where a large flock of birds of various kinds had gathered. When the holy one of God saw them, he swiftly ran to the spot and greeted them as though they had human reason. They all became alert and turned toward him, and those perched in the trees bent their heads as he approached them and in an uncommon way directed their attention to him. He approached them and intently encouraged them all to hear the word of God, saying: "My brother birds, you should greatly praise your Creator, who clothed you with feathers, gave you wings for flight, confided to you purity of the air, and governs you without your least care." While he was saying this and similar things to them, the birds fluttered about in a wonderful way. They began to stretch their necks, spread their wings, open their beaks, and look at him. He passed through their midst with amazing fervor of spirit, touching them with his tunic. Yet none of them left the place until the man of God made the sign of the cross and gave them a blessing and permission to leave; then they all flew away together. His companions waiting along the way contuited all these things. Upon returning to them, the pure and simple man began to accuse himself of negligence because he had not previously preached to the birds." 620

${ }^{620}$ Bonaventure and Commission on the Franciscan Intellectual Tradition, "Legenda Maior"; Bonaventure and Cousins, Bonaventure: Soul's Journey, 294-95. 


\section{Appendix 9 The Spirit of Charity and the Feeling of Compassion for the Poor that Glowed in Him for What He Did with the Sheep and the Lambs, Thomas of Celano, Vita Prima Chapter XXVIII}

77 The holy man overflowed with the spirit of charity, bearing within himself a deep sense of concern not only toward other humans in need but also toward mute, brute animals: reptiles, birds, and all other creatures whether sensate or not. But among all the different kinds of creatures, he loved lambs with a special fondness and spontaneous affection, since in Sacred Scripture the humility of our Lord Jesus Christ is frequently and rightly compared to the lamb. He used to embrace more warmly and to observe more gladly anything in which he found an allegorical likeness to the Son of God.

Once he was making a journey through the Marches of Ancona and preached the word of the Lord Acts 15:36 in the city. Then he took the road toward Osimo, with lord Paul, the one whom he had appointed minister Acts 26:16 of all the brethren in that province. He came upon a shepherd in the fields pasturing a flock of goats. There was one little sheep walking humbly and grazing calmly among these many goats. When blessed Francis saw it, he stopped in his tracks, and touched with sorrow in his heart, Gn 6:6 he groaned loudly, and said to the brother accompanying him: "Do you see that sheep walking so meekly among those goats? I tell you, in the same way our Lord Jesus Christ, meek and humble, Mt 11:29 walked among the Pharisees and chief priests. So I ask you, my son, in your love for Him to share my compassion for this little sheep. After we have paid for it, let us lead this little one from the midst Ps 136:11 [Vulgate, Ps 135:11] of these goats." 78 Brother Paul was struck by his sorrow and also began to feel that sorrow himself. They had nothing except the cheap tunics they wore and they were concerned about how to pay for the sheep, when suddenly a traveling merchant arrived and offered to pay for what they wanted. Taking up the sheep, they gave thanks to God and after reaching Osimo made their way to the bishop of the city, who received them with great reverence. Now the lord bishop was surprised both at the sheep the man of God $2 \mathrm{Kgs}$ 24:9 was leading and at the affection for it that was leading him to do this. But when the servant of Christ recounted the long parable of the sheep, the bishop was touched in his heart Acts 2:37 by the purity of the man of God, and gave thanks to God. Acts 27:35

The next day, on leaving the city, the man of God began to wonder what to do with the sheep. On the advice of his companion and brother, he entrusted it to the care of the maidservants of Christ in the cloister of San Severino. The venerable servants of Christ gladly received the little sheep as a great gift from God. 2 Mc 15:16 They devotedly cared for the sheep for a long time and made a tunic from its wool, a tunic they sent to the blessed father Francis at the church of Saint Mary of the Portiuncula at the time of a chapter meeting. The holy man of God received the tunic with great reverence and high spirits, hugging and kissing it, and invited all those around him to share this great joy.

${ }^{79}$ On another occasion he was traveling through the Marches and the same brother was gladly accompanying him when he came across a man on his way to market. The man was carrying over his shoulder two little lambs bound and ready for sale. When blessed Francis heard the bleating lambs, his innermost heart was touched $1 \mathrm{Kgs}$ 3:26 and, 
drawing near, he touched them as a mother does with a crying child, showing his compassion. "Why are you torturing my brother lambs," he said to the man, "binding and hanging them this way?" "I am carrying them to market to sell them, since I need the money," he replied. The holy man asked: "What will happen to them?" "Those who buy them will kill them and eat them," he responded. At that, the holy man said: "No, this must not happen! Here, take my cloak as payment and give me the lambs." The man readily gave him the little lambs and took the cloak since it was much more valuable. The cloak was one the holy man had borrowed from a friend on the same day to keep out the cold. The holy man of God, having taken the lambs, now was wondering what he should do with them. Asking for advice from the brother who was with him, he gave them back to that man, ordering him never to sell them or allow any harm to come to them, but instead to preserve, nourish, and guide them carefully. ${ }^{621}$

621 Thomas of Celano and Commission on the Franciscan Intellectual Tradition, "Vita Prima"; Thomas et al., Francis Trilogy, 88-89. 


\section{Appendix 10 Relevant Bibliography for Artwork}

\section{Pitsa Panel, Sicyon, Corinthia}

Jones, Nathaniel B. "Ancient Painted Panels: Terminology and Appearance." Mnemosyne 67, no. 2 (2014): 295-304.

Orlandos, Anastasios K. Pitsà. Roma: Enciclopedia dell' Arte Classica e Orientale. 6.Roma : Istituto dell' Enciclopedia Italiana fondata da Giovanni Treccani, 1964.

Mathews, Thomas F, Norman E Muller, and J. Paul Getty Museum, The Dawn of Christian Art in Panel Paintings and Icons. Los Angeles: J. Paul Getty Museum, 2016.

\section{Fresco of Francis of Assisi, Monastery of Subiaco}

Benedictine Fathers of Subiaco. The Shrine of the Holy Grotto, Subiaco: The Holy Grotto and the Monastery of St. Scholastica: An Artistic Guide for the Visit of the Monastery. Subiaco, Italy: Monastery of St. Benedict, 2001.

Brooke, Rosalind B. The Image of St Francis: Responses to Sainthood in the Thirteenth Century. Cambridge: Cambridge Univ. Press, 2009.

Goffen, Rona. Spirituality in Conflict: Saint Francis and Giotto's Bardi Chapel, University Park: Pennsylvania State University Press, 1988.

\section{Icons of Francis of Assisi (general)}

Cook Fraternal, William. "Fraternal and Lay Images of St. Francis in the Thirteenth Century." In Popes, Teachers, and Canon Law in the Middle Ages, edited by James Ross Sweeney and Stanley Chodorow. Ithaca: Cornell University Press, 1989.

Cook, Margarito d'Arezzo, William Robert. "Margarito d'Arezzo's Images of St Francis: A Different Approach to Chronology." Arte Cristiana / a Cura Della Scuola Beato Angelico e Dell'Istituto Di Storia Dell'Arte Dell'Università Cattolica, Associata al Centro d'Azione Liturgica e All'Unione Della Stampa Periodica Italiana., 1995, 83-90.

Cook, William R. Images of St. Francis of Assisi: In Painting, Stone, and Glass : From the Earliest Images to ca. 1320 in Italy: A Catalogue. Firenze; Perth [W.A.]: L.S. Olschki ; Dept. of Italian of the University of W. Australia, 1999. . "My Life with Francis." In The World of St. Francis of Assisi: Essays in Honor of William R. Cook, edited by Bradley Franco and William Robert Cook. Boston: Brill, 2015.

Derbes, Anne, and Amy Neff. "Italy, the Mendicant Orders, and the Byzantine Sphere." In Byzantium: Faith and Power (1261-1557), edited by Helen C Evans. New Haven: Yale University Press, 2004.

Garrison, Edward B. Italian Romanesque Panel Painting: An Illustrated Index. New York: Hacker Art Books, 1976. 
—. "Note on the Survival of Thirteenth-Century Panel Paintings in Italy." Artbulletin The Art Bulletin 54, no. 2 (1972): 140.

Tartuferi, Angelo, Francesco D'Arelli, and Museo dell'Accademia Fierenze. L'Arte di Francesco: Capolavori d'Arte Italiana e Terre d'Asia dal XIII al XV secolo : Firenze, Galleria dell'Accademia, 31 Marzo - 11 Ottobre 2015. Firenze: Giunti, 2015.

Uzielli, Luca. "Historical Overview of Panel-Making Techniques in Central Italy." In The Structural Conservation of Panel Paintings: Proceedings of a Symposium at the J. Paul Getty Museum, 24-28 April 1995., by Kathleen Dardes and Andrea Rothe. Los Angeles: Getty Conservation Institute, 2013.

\section{Icone di San Francesco di Assisi by Margarito d'Arezzo, Il Museo Nazionale d'Arte Medievale e Moderna, Arezzo}

Boccia, Lionello Giorgio, Anna Maria Maetzke, Carla Corsi, and Albino Secchi. Arte nell'Aretino: Recuperi e Restauri dal 1968 al 1974 : Arezzo, San Francesco, 14 Dicembre 1974-2 Febbraio 1975. Firenze: Edam, 1974.

\section{Vitae Dossals (general)}

Ahlquist, Gregory W, and William Robert Cook. "The Representation of the Posthumous Miracles of St Francis of Assisi in Thirteenth-Century Italian Painting." Art of the Franciscan Order in Italy / Ed. by William R. Cook., 2005, 211-56.

Cook Fraternal, William. "Fraternal and Lay Images of St. Francis in the Thirteenth Century." In Popes, Teachers, and Canon Law in the Middle Ages, edited by James Ross Sweeney and Stanley Chodorow. Ithaca: Cornell University Press, 1989.

Cook, Margarito d'Arezzo, William Robert. "Margarito d'Arezzo's Images of St Francis: A Different Approach to Chronology." Arte Cristiana / a Cura Della Scuola Beato Angelico e Dell'Istituto Di Storia Dell'Arte Dell'Università Cattolica, Associata al Centro d'Azione Liturgica e All'Unione Della Stampa Periodica Italiana., 1995, 83-90.

Cook, William R. Images of St. Francis of Assisi: In Painting, Stone, and Glass : From the Earliest Images to ca. 1320 in Italy: A Catalogue. Firenze; Perth [W.A.]: L.S. Olschki; Dept. of Italian of the University of W. Australia, 1999.

-. "My Life with Francis." In The World of St. Francis of Assisi: Essays in Honor of William R. Cook, edited by Bradley Franco and William Robert Cook. Boston: Brill, 2015.

Franco, Bradley R. "The Functions of Franciscan Art.” In The World of St. Francis of Assisi: Essays in Honor of William R. Cook, edited by Steven J. McMichael, 1944. Leiden: Brill, 2015.

Garrison, Edward B. Italian Romanesque Panel Painting: An Illustrated Index. New York: Hacker Art Books, 1976. . "Note on the Survival of Thirteenth-Century Panel Paintings in Italy." Artbulletin The Art Bulletin 54, no. 2 (1972): 140. 
Tartuferi, Angelo, Francesco D'Arelli, and Italie) Museo dell'accademia (Florence. $L$ 'arte di Francesco: capolavori d'arte italiana e terre d'Asia dal XIII al XV secolo: [Firenze, Galleria dell'Accademia, 31 marzo - 11 ottobre 2015. Firenze: Giunti, 2015.

Uzielli, Luca. "Historical Overview of Panel-Making Techniques in Central Italy." In The Structural Conservation of Panel Paintings: Proceedings of a Symposium at the J. Paul Getty Museum, 24-28 April 1995., by Kathleen Dardes and Andrea Rothe. Los Angeles: Getty Conservation Institute, 2013.

\section{San Francesco e Scene della sua Vita, Basilica di Santa Croce, Cappella Bardi, Florence}

Cook, New Sources, William. "New Sources, New Insights: The Bardi Dossal of the Life of St. Francis of Assisi." Studi Francescani. Firenze 93 (1996): $325-46$.

Goffen, Rona. Spirituality in Conflict: Saint Francis and Giotto's Bardi Chapel, University Park: Pennsylvania State University Press, 1988.

\section{San Francesco e Quattro Scene, Museo d'Arte Sacra di Orte}

Cook, Orte, William Robert. "The Orte Dossal: A Traditional and Innovative Life of St. Francis of Assisi." Arte Medievale / Istituto Della Enciclopedia Italiana. 2 (1996): 41-47.

Torriti, Paolo, ed. Al tempo del beato Mansueto: Castiglion Fiorentino e il suo territorio nel Duecento. Firenze: Scramasax, 2006.

Zuppante, Abbondio. “(In Press) L'eresia Nella Tuscia Del Duecento e Il Dossale Di San Francesco Di Orte." Edited by C. Canonici, F. De Macedo. Faleritanum. Rivista Di Teologia e Scienze Religiose Aracne; Anno III (2018).

\section{San Francesco, Storie della sua Vita e Miracoli Dopo la Morte, Pistoia}

Pistoia (Italy), Museo civico, Maria Cecilia Mazzi, and Pistoia (Italy). Museo civico di Pistoia: catalogo delle collezioni. Firenze: La nuova Italia, 1982.

\section{San Francesco e Storie della sua Vita, Pinacoteca Nazionale Siena}

Cook, Siena, William R. "The St. Francis Dossal in Siena: An Important Interpretation of the Life of Francis of Assisi." Archivum Franciscanum Historicum., 1994, 3-20.

\section{Crucifixes (general)}


Cannon, Joanna. "Reviews of Exhibitions: The Era of the Great Painted Crucifix: Giotto, Cimabue, Giunta Pisano, and Their Anonymous Contemporaries." Renaissance Studies 16, no. 4 (2002): 566-81.

Cooper, Donal. "Experiencing Dominican and Franciscan Churches in Renaissance Italy." In Sanctity Pictured: The Art of the Dominican and Franciscan Orders in Renaissance Italy, edited by Trinita Kennedy, 2014.

. "Preaching amidst Pictures: Visual Contexts for Sermons and Late Medieval Tuscany." In Optics, Ethics, and Art in the Thirteenth and Fourteenth Centuries: Looking into Peter of Limoges's Moral Treatise on the Eye, 29-45. Toronto, Ontario: Pontifical Institute of Medieval Studies, 2018.

. "Projecting Presence: The Monumental Cross in the Italian Church Interior." Presence / Ed. by Robert Maniura and Rupert Sheperd., 2006, 47-69.

Cooper, Donal, and Janet Robson. The Making of Assisi: The Pope, the Franciscans and the Painting of the Basilica. New Haven: Yale University Press, 2013.

Derbes, Anne. Picturing the Passion in Late Medieval Italy: Narrative Painting, Franciscan Ideologies, and the Levant. Cambridge; New York: Cambridge University Press, 1996.

Herbst, Thomas, OFM, "The Humanization of Christ in the Central Italian Panel Crucifixes of the Twelfth and Thirteenth-Centuries Reflected in the Development of Franciscan Christology.” Berkeley, California, Franciscan School of Theology, Graduate Theological Union. 1989.

Kennedy, Trinita, Donal Cooper, Holly Flora, Trinita Kennedy, Amy Neff, Janet Robson, Frist Center for the Visual Arts. Sanctity Pictured: The Art of the Dominican and Franciscan Orders in Renaissance Italy. London: Philip Wilson Publishers. 2014. Lunghi, 2002, Elvio. "Francis of Assisi in Prayer before the Crucifix in the Accounts of the First Biographers." Studies in the History of Art / Publ. by the National Gallery of Art, Washington, 2002, 340-53.

\section{Cross of Maestro Guglielmo, Cathedral of Sarzana}

Ciatti, Marco. Pinxit Guillielmus - il restauro della Croce di Sarzana. Firenze: Edifir, 2001.

Mormandi, Giuseppina. "Il culto della Santa Croce nella diocesi di LuniSarzana," Giornale storico della Lunigiana e del territorio lucense I Istituto Internazionale di Studi Liguri, Sezione Lunense, La Spezia ; Sezione Lucense, Lucca., 2016

\section{Cross of San Damiano, Assisi}

Pani Ermini, Letizia, Maria Grazia Fichera, Maria Letizia Mancinelli, and Filippo Ermini. Indagini archeologiche nella chiesa di San Damiano in Assisi. S. Maria degli Angeli, Italy: Porziuncola, 2005.

Bałdyga, Sergiusz M., The San Damiano Cross. Assisi: Edizioni Porziuncola. 2005.

Bollati, Milvia and Carlo Fadin, Francesco e la croce di S. Damiano, Fonti e Ricerche 25. Milano: Edizioni Biblioteca Francescana, 2016. 


\section{Crocifisso con San Francesco, Gualdo Tadino}

De Vecchi, Pierluigi, Pinacoteca Comunale (Gualdo Tadino), Umbria, and Servizio Musei e Beni Culturali. Museo Civico di Gualdo Tadino. decorazione murale, dipinti, materiali lapidei, sculture, arredo civile ed ecclesiastico, tessuti 1, 1. Perugia: Electa Editori Umbri Associati, 2000.

\section{Cristo Crocifisso, Chiesa Museo di San Francesco, Montefalco}

Pinacoteca-Museo Comunale, Ex. Chiesa di San Francesco (Montefalco), and Bruno Toscano. Museo Comunale di San Francesco a Montefalco. Perugia: Electa, Ed. Umbri Assoc., 1990. 


\section{Catalogs}

An interactive Map of Early Franciscan Wood-Panel Art can be accessed at: https://tinyurl.com/ybzj7w9w

\section{Catalog 1 Icons of Francis ${ }^{622}$}

\begin{tabular}{|c|c|c|c|c|c|}
\hline Location & $\begin{array}{l}\text { Date of } \\
\text { Production }\end{array}$ & $\begin{array}{l}\text { Size } \\
\text { Height } x \\
\text { Width }\end{array}$ & Artist & $\begin{array}{l}\text { Cross or Book } \\
\text { Present }\end{array}$ & Image \\
\hline $\begin{array}{l}\text { Rome, Vatican } \\
\text { Pinacoteca } \\
\text { Probably } \\
\text { originally in a } \\
\text { papal chapel }\end{array}$ & $\begin{array}{l}\text { Cook: Early } \\
1250 \mathrm{~s} \\
\text { Museum dates } \\
\text { to } 1240-1260\end{array}$ & $\begin{array}{l}122 \text { x } 40 \mathrm{~cm} \\
\text { Museum records } \\
\text { Dimensions at } \\
128 \times 54 \mathrm{~cm}\end{array}$ & $\begin{array}{l}\text { Margarito } \\
\text { d'Arezzo }\end{array}$ & $\begin{array}{l}\text { Book with cross in } \\
\text { tooled gold }\end{array}$ & $\begin{array}{l}\text { https://upload.wikimedia.org/wikipedia/c } \\
\text { ommons/7/7d/Margaritone_d\%27arezzo } \\
\text { \%2C_s._francesco\%2C_1270- } \\
\underline{\text { 80_ca.JPG }}\end{array}$ \\
\hline $\begin{array}{l}\text { Castiglion } \\
\text { Fiorentino, } \\
\text { Pinacoteca } \\
\text { Comunale }\end{array}$ & c. 1260 & $102 \times 39 \mathrm{~cm}$ & $\begin{array}{l}\text { Margarito } \\
\text { d'Arezzo }\end{array}$ & $\begin{array}{l}\text { Cross } \\
\text { Book with floral } \\
\text { and geometric } \\
\text { design in tooled } \\
\text { gold }\end{array}$ & $\begin{array}{l}\text { https://www.museicastiglionfiorentino.it/ } \\
\text { en/the-art-gallery/\# }\end{array}$ \\
\hline $\begin{array}{l}\text { Montepulciano, } \\
\text { Museo Civico, }\end{array}$ & c. 1260 & $120 \times 47 \mathrm{~cm}$ & $\begin{array}{l}\text { Margarito } \\
\text { d'Arezzo }\end{array}$ & Cross & $\begin{array}{l}\text { https://upload.wikimedia.org/wikipedia/c } \\
\text { ommons/a/a8/Margaritone_d\%27arezzo }\end{array}$ \\
\hline
\end{tabular}

${ }^{622}$ Unless otherwise noted, Catalog 1 information is based on Cook, Images of St. Francis of Assisi.

令 


\begin{tabular}{|c|c|c|c|c|c|}
\hline $\begin{array}{l}\text { From San } \\
\text { Francesco, } \\
\text { Montepulciano }\end{array}$ & & & & $\begin{array}{l}\text { Book with floral } \\
\text { and geometric } \\
\text { design in tooled } \\
\text { gold }\end{array}$ & $\begin{array}{l}\text { \%2C_san_francesco\%2C_xiii_secolo\%2 } \\
\text { C_da_s._francesco_01.jpg }\end{array}$ \\
\hline $\begin{array}{l}\text { Siena, } \\
\text { Pinacoteca } \\
\text { Nazionale, } \\
\text { Original } \\
\text { location } \\
\text { Unknown }\end{array}$ & $\begin{array}{l}\text { 1240s or early } \\
1250 \text { s } \\
\text { Museum dates } \\
\text { to } 1270-1280\end{array}$ & $95 \times 37 \mathrm{~cm}$ & $\begin{array}{l}\text { Margarito } \\
\text { d'Arezzo }\end{array}$ & $\begin{array}{l}\text { Book with floral } \\
\text { and geometric } \\
\text { design in tooled } \\
\text { gold }\end{array}$ & $\begin{array}{l}\text { https://upload.wikimedia.org/wikipedia/c } \\
\text { ommons/b/b6/2_Margaritone_d\%27Arez } \\
\text { zo\%2C_St._Francis\%2C_Siena\%2C_Pin } \\
\text { acoteca.jpg }\end{array}$ \\
\hline $\begin{array}{l}\text { Arezzo, } \\
\text { Galleria e } \\
\text { Museo } \\
\text { Medievale e } \\
\text { Moderno } \\
\text { From San } \\
\text { Francesco, } \\
\text { Sargiano }\end{array}$ & $\begin{array}{l}\text { 1240s or early } \\
1250 \mathrm{~s} \\
\text { Museum dates } \\
\text { c. } 1260-1275\end{array}$ & $130 \times 53 \mathrm{~cm}$ & $\begin{array}{l}\text { Margarito } \\
\text { d'Arezzo } \\
\text { Museum } \\
\text { attributes to } \\
\text { Margarito } \\
\text { d'Arezzo and } \\
\text { Assistant }\end{array}$ & $\begin{array}{l}\text { Book with cross in } \\
\text { tooled gold }\end{array}$ & $\begin{array}{l}\text { https://upload.wikimedia.org/wikipedia/c } \\
\text { ommons/5/59/Margaritone_d\%27arezzo_ } \\
\text { st_francis_arezzo_museum.jpg }\end{array}$ \\
\hline $\begin{array}{l}\text { Arezzo, } \\
\text { Galleria e } \\
\text { Museo } \\
\text { Medievale e } \\
\text { Moderno } \\
\text { Original } \\
\text { location } \\
\text { probably San }\end{array}$ & $\begin{array}{l}1235-1245 \\
\text { Museum dates } \\
\text { to c. } 1260- \\
1285\end{array}$ & $127 \times 45 \mathrm{~cm}$ & $\begin{array}{l}\text { Workshop of } \\
\text { Margarito } \\
\text { d'Arezzo }\end{array}$ & $\begin{array}{l}\text { Book with plain } \\
\text { silver cover }\end{array}$ & $\begin{array}{l}\text { https://upload.wikimedia.org/wikipedia/c } \\
\text { ommons/8/83/4_Margarito_d\%E2\%80\% } \\
\text { 99Arezzo_E_ignoto_toscano\%2C_San_F } \\
\text { rancesco\%2C_Arezzo\%2C_Museo_Nazi } \\
\text { onale_d\%E2\%80\%99arte_medievale_e } \\
\text { moderna.jpg }\end{array}$ \\
\hline
\end{tabular}




\begin{tabular}{|c|c|c|c|c|c|}
\hline $\begin{array}{l}\text { Francesco, } \\
\text { Ganghereto }\end{array}$ & & & & & \\
\hline $\begin{array}{l}\text { Assisi, Museo } \\
\text { della } \\
\text { Porziuncola, } \\
\text { Santa Maria } \\
\text { degli Angeli }\end{array}$ & c. 1255 & $108 \times 58.5 \mathrm{~cm}$ & $\begin{array}{l}\text { St. Francis } \\
\text { Master }\end{array}$ & $\begin{array}{l}\text { Angels flank, } \\
\text { holding cross and } \\
\text { open book with } \\
\text { text: Hic michi } \\
\text { viventi lectus fuit } \\
\text { et morienti /I } \\
\text { chose him while I } \\
\text { lived and as I } \\
\text { died }^{623}\end{array}$ & $\begin{array}{l}\text { https://www.wikiwand.com/en/Master_of } \\
\text { _Saint_Francis }\end{array}$ \\
\hline
\end{tabular}

${ }^{623}$ Rona Goffen, Spirituality in Conflict: Saint Francis and Giotto's Bardi Chapel, 1988, 15. 


\begin{tabular}{|c|c|c|c|c|c|}
\hline $\begin{array}{l}\text { Musée du } \\
\text { Louvre } \\
\text { Original } \\
\text { location } \\
\text { unknown }\end{array}$ & $\begin{array}{l}\text { c. } 1260 \\
\text { Museum dates } \\
\text { to } 1235-1240\end{array}$ & $95.5 \times 39 \mathrm{~cm}$ & $\begin{array}{l}\text { Roman artist; } \\
\text { Louvre relates } \\
\text { to artist of } \\
\text { Cathedral of } \\
\text { Anagni, Lazio }\end{array}$ & $\begin{array}{l}\text { Holding open book } \\
\text { with text: } \\
\text { Spiritus domini } \\
\text { super me } \\
\text { evangelizare } \\
\text { caesis visum (The } \\
\text { spirit of the Lord is } \\
\text { upon me...to bring } \\
\text { good news to the } \\
\text { poor) }\end{array}$ & $\begin{array}{l}\text { cartelfr.louvre.fr/cartelfr/visite?srv=obj_v } \\
\text { iew_obj\&objet=cartel_1228_1375_p0003 } \\
\text { 854.001.jpg_obj.html\&flag=true }\end{array}$ \\
\hline $\begin{array}{l}\text { Assisi, Museo } \\
\text { della } \\
\text { Porziuncola, } \\
\text { Santa Maria } \\
\text { degli Angeli }\end{array}$ & $\begin{array}{l}\text { Early } 1280 \mathrm{~s} \\
\text { Museum dates } \\
\text { to } 1290 \mathrm{~s}\end{array}$ & $123 \times 41 \mathrm{~cm}$ & $\begin{array}{l}\text { Cimabue or } \\
\text { close follower } \\
\text { (possibly } \\
\text { coffin cover, } \\
\text { according to } \\
\text { museum) }\end{array}$ & $\begin{array}{l}\text { Closed red book } \\
\text { with scrollwork on } \\
\text { spine }\end{array}$ & $\begin{array}{l}\text { https://upload.wikimedia.org/wikipedia/c } \\
\text { ommons/e/ee/Cimabue_ } \% 28 \text { attr. } \% 29 \% 2 \\
\text { C_tavola_di_san_francesco\%2C_museo } \\
\text { della_porziuncola.jpg }\end{array}$ \\
\hline
\end{tabular}


Catalog 2 Vita Dossals ${ }^{624}$

\begin{tabular}{|c|c|c|c|c|c|}
\hline $\begin{array}{l}\text { Vita Dossal } \\
\text { Current location }\end{array}$ & $\begin{array}{l}\text { Artist } \\
\text { Date of production }\end{array}$ & Size & Image & N.B. & Posthumous Miracles \\
\hline $\begin{array}{l}\text { San Francesco e } \\
\text { Storie della sua } \\
\text { Vita } \\
\text { Chiesa di San } \\
\text { Francesco, Pescia }\end{array}$ & $\begin{array}{l}\text { Bonaventura } \\
\text { Berlinghieri } \\
1235\end{array}$ & $\begin{array}{l}160 \times 123 \\
\mathrm{~cm}\end{array}$ & $\begin{array}{l}\text { https://it.wikipedia.org/wiki/San } \\
\text { _Francesco_e_storie_della_sua_ } \\
\text { vita\#/media/File:Bonaventura_B } \\
\text { erlingieri_- } \\
\text { _St_Francis_of_Assisi.jpg }\end{array}$ & $\begin{array}{l}\text { Book with } \\
\text { geometric } \\
\text { cover } \\
\text { decoration }\end{array}$ & $\begin{array}{c}\text { Girl with a twisted neck } \\
\text { Bartholomew of Narni } \\
\text { Exorcism } \\
\text { Healing of people with } \\
\text { disabilities/diseases/ } \\
\text { pilgrims }\end{array}$ \\
\hline $\begin{array}{l}\text { San Francesco e } \\
\text { Venti Storie della } \\
\text { sua Vita } \\
\text { Basilica di Santa } \\
\text { Croce, Cappella } \\
\text { Bardi, Florence }\end{array}$ & $\begin{array}{l}\text { Maestro del San } \\
\text { Francesco Bardi } \\
\text { Or possibly Coppo } \\
\text { di Marcovaldo, } \\
\text { active } 1240-1260 \\
\text { c. } 1245\end{array}$ & $\begin{array}{l}234 \times 127 \\
\mathrm{~cm} \\
230 \times 123 \\
\mathrm{~cm}^{625}\end{array}$ & $\begin{array}{l}\text { https://upload.wikimedia.org/wik } \\
\text { ipedia/commons/b/b4/Master_of } \\
\text { the_bardi_saint_francis_._St._F } \\
\text { rancis_and_scenes_from_his_lif } \\
\text { e_13_cent_Santa_croce.jpg }\end{array}$ & $\begin{array}{l}\text { Book with } \\
\text { cross on cover }\end{array}$ & $\begin{array}{l}\text { Girl with a twisted neck } \\
\qquad \& \text { Exorcism } \\
\text { Bartholomew of Narni } \\
\text { healed of gout }\end{array}$ \\
\hline
\end{tabular}

${ }^{624}$ Unless otherwise noted, Catalog 2 information is based on Cook, Images of St. Francis of Assisi.

${ }^{625}$ Angelo Tartuferi, Francesco D'Arelli, and Italie Museo dell'Accademia Firenze, L'Arte di Francesco: Capolavori d'Arte Italiana e Terre d'Asia dal XIII al XV secolo : Firenze, Galleria dell'Accademia, 31 Marzo - 11 Ottobre 2015 (Firenze: Giunti, 2015), 280. 


\begin{tabular}{|c|c|c|c|c|c|}
\hline & & & & & $\begin{array}{l}\text { Healing of people with } \\
\text { disabilities during } \\
\text { Francis' funeral } \\
\text { Francis rescuing } \\
\text { seafarers } \\
\text { Pilgrims bringing } \\
\text { candles to Francis' tomb } \\
\text { or a miracle granted to } \\
\text { penitents }\end{array}$ \\
\hline $\begin{array}{l}\text { San Francesco, } \\
\text { Storie della sua } \\
\text { Vita e Miracoli } \\
\text { Dopo la Morte } \\
\text { Museo Civici di } \\
\text { Pistoia }\end{array}$ & $\begin{array}{l}\text { Master of Cross } 434 \\
\text { Or Maestro di Santa } \\
\text { Maria Primarana } \\
\text { Museum attributes } \\
\text { to Master of Cross } \\
434 \text { who may be } \\
\text { Coppo di } \\
\text { Marcovaldo } \\
\text { c. } 1250 \text { or a little } \\
\text { later }\end{array}$ & $\begin{array}{l}162 \times 136 \\
\mathrm{~cm}\end{array}$ & $\begin{array}{l}\text { https://upload.wikimedia.org/wik } \\
\text { ipedia/commons/5/5e/Maestro_d } \\
\text { ella_croce_434_e_maestro_di_sa } \\
\text { nta_maria_primerana\%2C_san_f } \\
\text { rancesco_e_storie_della_sua_vit } \\
\text { a_\%28dettaglio\%29\%2C_pistoia } \\
\% 2 \text { C_museo_civico.jpg }\end{array}$ & $\begin{array}{l}\text { Book cover } \\
\text { with simple } \\
\text { decoration }\end{array}$ & $\begin{array}{l}\text { Girl with a twisted neck } \\
\text { Bartholomew of Narni } \\
\text { Exorcism } \\
\text { Healing of people with } \\
\text { disabilities/diseases/ } \\
\text { pilgrims }\end{array}$ \\
\hline $\begin{array}{l}\text { San Francesco e } \\
\text { Quattro Miracoli } \\
\text { Museo del } \\
\text { Tesoro }\end{array}$ & $\begin{array}{l}\text { Giunta Pisano (or an } \\
\text { anonymous Umbrian } \\
\text { master) }\end{array}$ & $\begin{array}{l}96 \times 138 \\
\mathrm{~cm}\end{array}$ & $\begin{array}{l}\text { https://upload.wikimedia.org/wik } \\
\text { ipedia/commons/4/4e/Frama_As } \\
\text { sSC040.JPG }\end{array}$ & $\begin{array}{l}\text { Holds Cross } \\
\text { and open book }\end{array}$ & $\begin{array}{l}\text { Girl with a twisted neck } \\
\text { Bartholomew of Narni } \\
\text { Exorcism }\end{array}$ \\
\hline
\end{tabular}

${ }^{626}$ The first description is from the signage at Santa Croce, while the second is given by Franco who believes the image is based on a local story rather than a textual source. Bradley R. Franco, "The Functions of Franciscan Art," in The World of St. Francis of Assisi: Essays in Honor of William R. Cook, ed. Steven J. McMichael (Leiden: Brill, 2015), 33. 


\begin{tabular}{|c|c|c|c|c|c|}
\hline $\begin{array}{l}\text { della } \\
\text { Basilica di } \\
\text { San } \\
\text { Francesco }\end{array}$ & $\begin{array}{l}\text { Museum attributes } \\
\text { to Maestro del } \\
\text { Tesoro } \\
\text { c. } 1253 \\
\text { Museum dates to c. } \\
1260\end{array}$ & & & & $\begin{array}{c}\text { Healing of people with } \\
\text { disabilities/diseases/ } \\
\text { pilgrims }\end{array}$ \\
\hline $\begin{array}{l}\text { San } \\
\text { Francesco } \\
\text { e Quattro } \\
\text { Scene } \\
\text { Museo d'Arte } \\
\text { Sacra di Orte }\end{array}$ & $\begin{array}{l}\text { Maestro del San } \\
\text { Francesco di Orte or } \\
\text { Maestro del dossale } \\
\text { di San Giovanni } \\
\text { Battista } \\
\text { c. } 1260 \\
1254-1259^{627}\end{array}$ & $\begin{array}{l}180 \times 80 \\
\mathrm{~cm}\end{array}$ & $\begin{array}{l}\text { https://media.gettyimages.com/p } \\
\text { hotos/st-francis-and-stories-of- } \\
\text { his-life-by-an-unknown-artist- } \\
\text { from-orte-picture- } \\
\text { id148277273?s=2048x2048 }\end{array}$ & $\begin{array}{l}\text { Book } \\
\text { decorated with } \\
\text { jeweled cover }\end{array}$ & $\begin{array}{l}\text { Posthumous Cathar } \\
\text { reconciliation miracle } \\
\text { incorporating an icon }\end{array}$ \\
\hline $\begin{array}{l}\text { San Francesco e } \\
\text { Quattro Miracoli } \\
\text { Post-Mortem } \\
\text { Vatican } \\
\text { Pinacoteca, Rome }\end{array}$ & $\begin{array}{l}\text { Follower of Giunta } \\
\text { Pisano } \\
\text { Museum attributes } \\
\text { to Giunta Pisano } \\
\text { c. } 1255\end{array}$ & $\begin{array}{l}67 \times 86.5 \\
\mathrm{~cm}\end{array}$ & $\begin{array}{l}\text { https://it.wikipedia.org/wiki/San } \\
\text { _Francesco_e_quattro_miracoli_- } \\
\text { post- } \\
\text { mortem\#/media/File:Giunta_Pisa } \\
\text { no._St_Francisc.1260- } \\
\text { 70._Vatican._Pinacoteca.jpg }\end{array}$ & $\begin{array}{l}\text { Holds Cross } \\
\text { and open book } \\
\text { with no text }\end{array}$ & $\begin{array}{l}\text { Girl with a twisted neck } \\
\text { Bartholomew of Narni } \\
\text { Exorcism } \\
\text { Healing of people with } \\
\text { disabilities/diseases }\end{array}$ \\
\hline
\end{tabular}

${ }^{627}$ Abbondio Zuppante, “(In Press) L’Eresia Nella Tuscia Del Duecento e Il Dossale Di San Francesco Di Orte,” ed. C. Canonici, F. De Macedo, Faleritanum. Rivista Di Teologia e Scienze Religiose Aracne; Anno III (2018): Par. 61. 


\begin{tabular}{|c|c|c|c|c|c|}
\hline $\begin{array}{l}\text { Dossale con San } \\
\text { Francesco e Sei } \\
\text { Miracoli } \\
\text { Museo Nazionale } \\
\text { di San Matteo, } \\
\text { Pisa }\end{array}$ & $\begin{array}{l}\text { Attributed } \\
\text { to Giunta } \\
\text { Pisano } \\
\text { c. } 1255 \text {, or possibly } \\
\text { as early as 1230- } \\
1235 \\
\text { (Museum } \\
\text { dates } 1240- \\
1260 \text { ) }\end{array}$ & $\begin{array}{l}163 \times 129 \\
\mathrm{~cm} \\
\text { (Museum } \\
\text { records } \\
\text { Dimensions } \\
\text { at } \\
157 \times 133\end{array}$ & $\begin{array}{l}\text { https://it.wikipedia.org/wiki/Dos } \\
\text { sale_di_San_Francesco_e_sei_m } \\
\text { iracoli\#/media/File:Giunta_Pisan } \\
\text { o._St._Francisc_and_six_stories } \\
\text { from_his_life.Ca._1250- } \\
\text { 60._Museo_San_Matteo,_Pisa.jp } \\
\text { g }\end{array}$ & $\begin{array}{l}\text { Book with } \\
\text { cover tooled } \\
\text { vaguely with a } \\
\text { cross }\end{array}$ & $\begin{array}{l}\text { Girl with a twisted neck } \\
\text { Bartholomew of Narni } \\
\text { Exorcism } \\
\text { Healing of people with } \\
\text { disabilities/diseases/ } \\
\text { pilgrims } \\
\text { Girl with eyes falling } \\
\text { out } \\
\text { Woman with ulcer }\end{array}$ \\
\hline $\begin{array}{l}\text { San Francesco e } \\
\text { Storie della sua } \\
\text { Vita } \\
\text { Pinacoteca } \\
\text { Nazionale di Siena } \\
\text { Formerly in San } \\
\text { Francesco in Colle } \\
\text { Val d'Elsa }\end{array}$ & $\begin{array}{l}\text { Guido di Graziano } \\
\text { (Guido of Siena) } \\
\text { c. } 1280\end{array}$ & $\begin{array}{l}237 \times 113 \\
\mathrm{~cm}\end{array}$ & $\begin{array}{l}\text { https://upload.wikimedia.org/wik } \\
\text { ipedia/commons/5/56/Guido_di_ } \\
\text { graziano\%2C_san_francesco_e_- } \\
\text { storie_della_sua_vita\%2C_1278- } \\
\text { 1302_ca..JPG }\end{array}$ & $\begin{array}{l}\text { Book with } \\
\text { elaborately } \\
\text { decorated } \\
\text { cover } \\
\text { Holds a very } \\
\text { faint cross }\end{array}$ & No posthumous miracles \\
\hline
\end{tabular}


Catalog 3 Painted Wood-Panel Crucifixes ${ }^{628}$

\begin{tabular}{|c|c|c|c|c|c|c|c|c|}
\hline $\begin{array}{c}\text { Crucifix by } \\
\text { Current } \\
\text { Location } \\
\text { On-line } \\
\text { Image } \\
\text { Address }\end{array}$ & $\begin{array}{l}\text { Original } \\
\text { Location }\end{array}$ & $\begin{array}{c}\text { Height } \\
\text { x } \\
\text { Width }\end{array}$ & Date & $\begin{array}{c}\text { Apron } \\
\text { (Tabellone) } \\
\text { Decoration }\end{array}$ & Artist & $\begin{array}{c}\text { Additional } \\
\text { Figures }\end{array}$ & $\begin{array}{c}\text { Loincloth } \\
\text { (Perizoma) } \\
\text { Descriptio } \\
\text { n }\end{array}$ & $\begin{array}{c}\text { Francis' } \\
\text { Stigmat } \\
\text { a }\end{array}$ \\
\hline $\begin{array}{c}\begin{array}{c}\text { Assisi, } \\
\text { Basilica di } \\
\text { Santa } \\
\text { Chiara }\end{array} \\
\underline{\text { https://uploa }} \\
\begin{array}{l}\text { d.wikimedia. } \\
\text { org/wikipedi }\end{array} \\
\text { a/commons/d } \\
\text { /d1/Assisi\%2 } \\
\text { C_santa_chia } \\
\underline{\text { ra\%2C_inter }} \\
\text { no\%2C_mae } \\
\text { stro_di_santa } \\
\text { chiara\%2C } \\
\text { croce_dipin } \\
\text { ta_2.jpg }\end{array}$ & same & $\begin{array}{c}415 \mathrm{x} \\
300 \mathrm{~cm}\end{array}$ & c. 1260 & $\begin{array}{c}\text { Red and black } \\
\text { quatrefoil } \\
\text { diamonds/ } \\
\text { florals }\end{array}$ & $\begin{array}{l}\text { Master of Santa } \\
\text { Chiara (Master } \\
\text { of Donna } \\
\text { Benedetta), } \\
\text { possibly } \\
\text { identified as } \\
\text { Benvenuto } \\
\text { Benvieni }\end{array}$ & $\begin{array}{c}\text { Mary, John } \\
\text { (Full length) } \\
\text { Francis, Clare, } \\
\text { Abbess Donor } \\
\text { Donna Benedetta } \\
\text { Christ Pantocrator } \\
\text { Our Lady of the } \\
\text { Angels }\end{array}$ & $\begin{array}{l}\text { Cream } \\
\text { Opaque } \\
\text { Knotted }\end{array}$ & $\begin{array}{c}\text { Hand } \\
\text { wounds } \\
\text { visible }\end{array}$ \\
\hline
\end{tabular}

${ }^{628}$ Unless otherwise noted, Catalog 3 information is based on Cook, Images of St. Francis of Assisi. 


\begin{tabular}{|c|c|c|c|c|c|c|c|c|}
\hline $\begin{array}{c}\begin{array}{c}\text { Bologna, } \\
\text { Pinacoteca } \\
\text { Nazionale }\end{array} \\
\frac{\text { http://diversirobi. }}{\frac{\text { weebly.com/uploa }}{\text { ds/6/2/4/0/624013 }}} \\
\frac{8 / 3046504 . j p g ? 35}{\underline{7}}\end{array}$ & $\begin{array}{c}\text { San } \\
\text { Francesco, } \\
\text { Bologna }\end{array}$ & $\begin{array}{r}269 x \\
213 \mathrm{c} \\
\text { Cut do }\end{array}$ & $\begin{array}{c}\text { c. } \\
1265\end{array}$ & $\begin{array}{l}\text { Geometric } \\
\text { florals and bands } \\
\text { in burgundy, } \\
\text { green, and cream }\end{array}$ & $\begin{array}{l}\text { Probably an } \\
\text { Umbrian } \\
\text { follower of } \\
\text { Giunta Pisano }\end{array}$ & $\begin{array}{l}\text { Francis kneeling at a } \\
\text { distance } \\
\text { Termini are missing } \\
\text { St. Helen added to } \\
\text { tabellone in } \\
\text { fourteenth century } \\
\text { Christ Pantocrator } \\
\text { Our Lady of the } \\
\text { Angels }\end{array}$ & $\begin{array}{l}\text { Purple } \\
\text { Opaque } \\
\text { Knotted }\end{array}$ & $\begin{array}{c}\text { Hand } \\
\text { wounds } \\
\text { visible }\end{array}$ \\
\hline $\begin{array}{c}\begin{array}{c}\text { Faenza, } \\
\text { Pinacoteca } \\
\text { Civica }\end{array} \\
\text { https://www.pinac } \\
\text { otecafaenza.it/sale } \\
\text { /sala6/97-2/ }\end{array}$ & $\begin{array}{c}\text { Santa } \\
\text { Chiara, } \\
\text { Faenza }\end{array}$ & $\begin{array}{c}196 \mathrm{x} \\
155 \\
\mathrm{~cm}\end{array}$ & $\begin{array}{l}1260- \\
1270\end{array}$ & $\begin{array}{l}\text { Geometric } \\
\text { diamonds, bars, } \\
\text { circles }\end{array}$ & $\begin{array}{c}\text { Blue Crucifix } \\
\text { Master }\end{array}$ & $\begin{array}{c}\text { Mary, John } \\
\text { (full length) } \\
\text { Francis }\end{array}$ & $\begin{array}{l}\text { Purple } \\
\text { Opaque } \\
\text { Knotted }\end{array}$ & $\begin{array}{c}\text { Unknown } \\
\text { due to } \\
\text { damage }\end{array}$ \\
\hline $\begin{array}{c}\begin{array}{c}\text { Gualdo Tadino, } \\
\text { Museo Civico } \\
\text { Rocca Flea }\end{array} \\
\text { https://upload.wiki } \\
\text { media.org/wikiped } \\
\text { ia/commons/f/f7/ } \\
\text { Maestro_del_croci } \\
\text { fisso_di_gualdo_t } \\
\text { adino\%2C_crocifi } \\
\text { Sso_con_la_vergin } \\
\text { e\%2C_giovanni_e } \\
\text { san_francesco\%2 } \\
\text { C_1250- } \\
\text { 1300_ca._01.jpg }\end{array}$ & $\begin{array}{l}\text { Formerly } \\
\text { Church of } \\
\text { San } \\
\text { Francesco, } \\
\text { Gualdo } \\
\text { Tadino }\end{array}$ & $\begin{array}{c}302 \mathrm{x} \\
239 \\
\mathrm{~cm}\end{array}$ & $\begin{array}{c}\text { c. } \\
1270\end{array}$ & $\begin{array}{l}\text { Red squares with } \\
\text { green outlines }\end{array}$ & $\begin{array}{l}\text { Maestro del } \\
\text { Crocifisso di } \\
\text { Gualdo Tadino } \\
\text { or Master of } \\
\text { Santa Chiara }\end{array}$ & $\begin{array}{c}\text { Mary, John } \\
\text { (full length) } \\
\text { Francis }\end{array}$ & $\begin{array}{l}\text { Purple } \\
\text { Opaque } \\
\text { Knotted }\end{array}$ & $\begin{array}{c}\text { Hand } \\
\text { wounds } \\
\text { visible }\end{array}$ \\
\hline
\end{tabular}




\begin{tabular}{|c|c|c|c|c|c|c|c|c|}
\hline $\begin{array}{c}\begin{array}{c}\text { Perugia, } \\
\text { Galleria } \\
\text { Nationale } \\
\text { dell'Umbria }\end{array} \\
\underline{\text { https://it.wikipedia.o }} \\
\underline{\text { rg/wiki/Crocifisso d }} \\
\text { i_Perugia_del_Maes } \\
\text { tro di San Frances } \\
\text { co\#/media/File:Crus } \\
\underline{\text { ifix_Maestro_di_Sa }} \\
\text { n_Francesco._Perug } \\
\text { ia.jpg }\end{array}$ & $\begin{array}{l}\text { San } \\
\text { Francesco } \\
\text { al Prato, } \\
\text { Perugia }\end{array}$ & $\begin{array}{c}486 \mathrm{x} \\
325 \mathrm{~cm}\end{array}$ & $\begin{array}{c}1272 \\
\text { (dated) }\end{array}$ & $\begin{array}{l}\text { P. } \\
\text { Blue and red } \\
\text { floral }\end{array}$ & $\begin{array}{l}\text { St. Francis } \\
\text { Master }\end{array}$ & $\begin{array}{c}\text { Mary, John } \\
\text { (full length) } \\
\text { Francis } \\
\text { Christ Pantocrator } \\
\text { Our Lady of the } \\
\text { Angels }\end{array}$ & $\begin{array}{l}\text { Orange } \\
\text { Opaque } \\
\text { Knotted }\end{array}$ & $\begin{array}{l}\text { Hand and } \\
\text { foot } \\
\text { wounds }\end{array}$ \\
\hline $\begin{array}{c}\begin{array}{c}\text { Florence, } \\
\text { Villa Acton }\end{array} \\
\frac{\text { http://catalogo.fond }}{\text { azionezeri.unibo.it/f }} \\
\frac{\text { oto/40000/10800/10 }}{677 . j p g}\end{array}$ & $\begin{array}{l}\text { Origin } \\
\text { unknown }\end{array}$ & $\begin{array}{c}250 \mathrm{x} \\
162 \mathrm{~cm} \\
\\
\text { Cut } \\
\text { down }\end{array}$ & $\begin{array}{c}\text { c. } \\
1295\end{array}$ & $\begin{array}{l}\text { Apron removed } \\
\text { late fourteenth } \\
\text { or early } \\
\text { fifteenth } \\
\text { century }\end{array}$ & $\begin{array}{l}\text { Follower of St. } \\
\text { Francis Master }\end{array}$ & $\begin{array}{c}\text { Francis holding foot } \\
\text { Terminals are } \\
\text { missing }\end{array}$ & $\begin{array}{l}\text { Opaque } \\
\text { (no color } \\
\text { image } \\
\text { available) } \\
\text { Knotted }\end{array}$ & $\begin{array}{l}\text { Hand and } \\
\text { Foot } \\
\text { wounds } \\
\text { visible }\end{array}$ \\
\hline $\begin{array}{c}\begin{array}{c}\text { Nocera Umbra, } \\
\text { Pinacoteca } \\
\text { Comunale } \\
\text { Perugia }\end{array} \\
\text { https://upload.wikim } \\
\text { edia.org/wikipedia/c } \\
\text { ommons/5/54/Cristo } \\
\text { Crocifisso,_Piancot } \\
\text { eca Comunale di } \\
\text { Nocera_Umbra.JPG }\end{array}$ & $\begin{array}{l}\text { Church of } \\
\text { San } \\
\text { Francesco, } \\
\text { Nocera } \\
\text { Umbra }\end{array}$ & $\begin{array}{c}320 \mathrm{x} \\
252 \mathrm{~cm}\end{array}$ & $1280 \mathrm{~s}$ & $\begin{array}{l}\text { Red and black } \\
\text { floral } \\
\text { diamonds }\end{array}$ & $\begin{array}{c}\text { Master of the } \\
\text { Cross of Nocera } \\
\text { Umbra }\end{array}$ & $\begin{array}{c}\text { Mary, John } \\
\text { (full length) } \\
\text { Francis }\end{array}$ & $\begin{array}{l}\text { Red } \\
\text { Opaque } \\
\text { Knotted }\end{array}$ & $\begin{array}{l}\text { Hand and } \\
\text { foot } \\
\text { wounds } \\
\text { visible }\end{array}$ \\
\hline
\end{tabular}




\begin{tabular}{|c|c|c|c|c|c|c|c|c|}
\hline $\begin{array}{l}\text { Spello, Chiesa } \\
\text { di } \\
\text { Sant' Andrea } \\
\text { https://upload.wi } \\
\text { kimedia.org/wiki } \\
\text { pedia/commons/ } \\
\text { 0/00/Spello\%2C } \\
\text { _s._andrea\%2C_ } \\
\text { crocifisso_giotte } \\
\text { sco\%2C_inizio_t } \\
\text { recento\%2C_02. } \\
\text { JPG }\end{array}$ & $\begin{array}{l}\text { Probably } \\
\text { Spello; } \\
\text { possibly } \\
\text { Florence }\end{array}$ & $\begin{array}{l}250 \mathrm{x} \\
180 \\
\mathrm{~cm} \\
\text { Cut } \\
\text { down }\end{array}$ & $\begin{array}{c}\text { c. } \\
1290\end{array}$ & $\begin{array}{l}\text { Gold floral with } \\
\text { diamond outline } \\
\text { on burgundy field } \\
\text { Cut down apron }\end{array}$ & $\begin{array}{l}\text { An Umbrian } \\
\text { Master } \\
\text { (perhaps } \\
\text { Expressionist } \\
\text { Master of Santa } \\
\text { Chiara who is } \\
\text { probably } \\
\text { Palmerino di } \\
\text { Guido) }\end{array}$ & $\begin{array}{l}\text { Francis } \\
\text { Termini are } \\
\text { missing }\end{array}$ & $\begin{array}{c}\text { Ivory } \\
\text { Transparent } \\
\text { No knot }\end{array}$ & $\begin{array}{l}\text { Hand and } \\
\text { foot } \\
\text { wounds } \\
\text { visible }\end{array}$ \\
\hline $\begin{array}{c}\begin{array}{c}\text { Montefalco, } \\
\text { Chiesa Museo } \\
\text { di San } \\
\text { Francesco }\end{array} \\
\text { https://www.mus } \\
\text { eodimontefalco.i } \\
\frac{\text { t/en/gallery-of- }}{\text { the-st-francis- }} \\
\underline{\text { complex- }} \\
\text { museum_8.html }\end{array}$ & $\begin{array}{l}\text { Formerly } \\
\text { the } \\
\text { Church } \\
\text { of San } \\
\text { Francesc } \\
\text { o, } \\
\text { Montefal } \\
\text { co }\end{array}$ & $\begin{array}{c}300 \mathrm{x} \\
240 \\
\mathrm{~cm}\end{array}$ & $\begin{array}{c}\text { c. } \\
1300\end{array}$ & $\begin{array}{l}\text { Gold and brown } \\
\text { florals }\end{array}$ & $\begin{array}{l}\text { Expressionist } \\
\text { Master of Santa } \\
\text { Chiara } \\
\text { (who is } \\
\text { probably } \\
\text { Palmerino di } \\
\text { Guido) }\end{array}$ & $\begin{array}{c}\text { Mary, John } \\
\text { (half length) } \\
\text { Francis } \\
\text { Christ Pantocrator }\end{array}$ & $\begin{array}{c}\text { Ivory } \\
\text { Transpare } \\
\text { nt } \\
\text { No knot }\end{array}$ & $\begin{array}{c}\text { Hand } \\
\text { wounds } \\
\text { visible }\end{array}$ \\
\hline
\end{tabular}




\section{Maps}

An interactive Map of Early Franciscan Wood-Panel Art can be accessed at: https://tinyurl.com/ybzj7w9w

\section{Key for Maps 1 \& 2}

Documented Cathar Activity

- Orvieto

- Orte

- Viterbo

- Bologna

- Florence

- Perugia

- Rieti

- Spoleto

- Narni

- Chia

- Bagnoregio

- Radicofani

\section{Vita Dossals}

- Chiesa di San Francesco, Pescia

- Basilica di Santa Croce, Cappella Bardi, Florence

- Museo Civici di Pistoia

- Museo del

Tesoro della

Basilica di San

Francesco

- Museo d'Arte Sacra di Orte

- Vatican Pinacoteca, Rome

- Museo Nazionale di San Matteo, Pisa

- Pinacoteca Nazionale di Siena
Simple Icons of Francis

- Rome, Vatican Pinacoteca

- Castiglion Fiorentino, Pinacoteca Comunale

- Montepulciano, Museo Civico

- Siena, Pinacoteca Nazionale

- Arezzo, Galleria e Museo Medievale e Moderno

- Arezzo, Galleria e Museo Medievale e Moderno

- Rome, Chiesa di San Francesco a Ripa

- Assisi, Museo della Dorpiunonla Santa

Monumental Crucifixes with Francis of Assisi at Base

- Arezzo, Basilica di San Francesco

- Bologna, Pinacoteca Nazionale

- Assisi, Basilica ci Santa Chiara

- Faenza, Pinacoteca Civica

- Gualdo Tadino, Museo Civico Rocca Flea

- Perugia, Galleria Nationale dell'Umbria

- Florence, Villa Acton

- Nocera Umbra, Pinacoteca Comunale Perugia

- Spello, Sant' Andrea Church

- Montefalco, Chiesa Museo di San Francesco 


\section{Map 1 Thirteenth Century Wood-Panel Art Compared to Cathar Routes}

Based on a map by Malcolm Lambert, The Cathars ${ }^{629}$

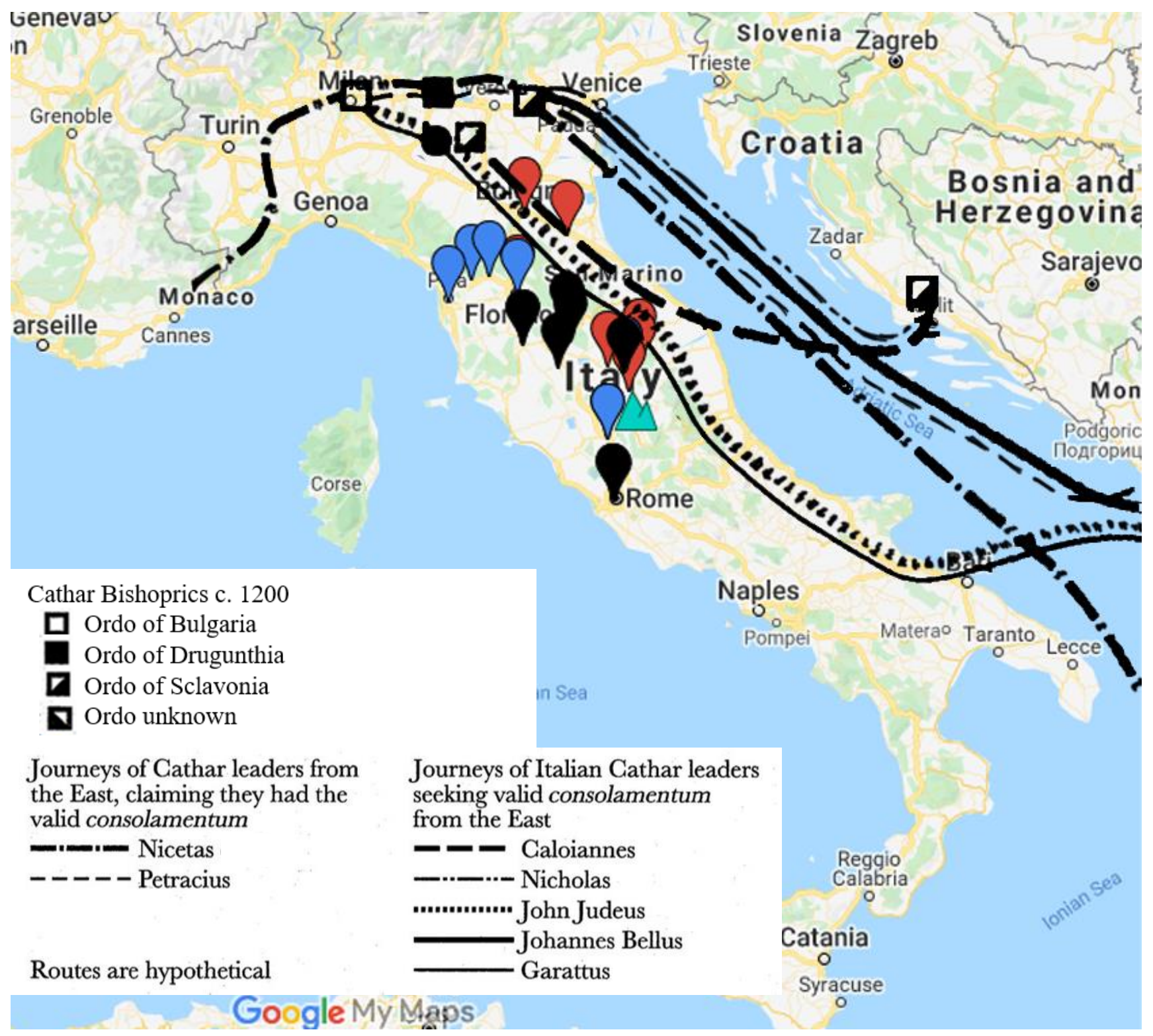

Google Maps https://tinyurl.com/ybzj7w9w

Map data (2020 GeoBasis-DE/BKG (@2009). Google. Inst. Geogr. Nacional.

${ }^{629}$ Malcolm Lambert, The Cathars (Oxford. UK; Malden, Mass., USA: Blackwell Publishers, 1998), 52. https://tinyurl.com/ybzj7w9w 


\section{Map 2 Thirteenth Century Wood-Panel Art compared with known}

\section{Cathar activity}

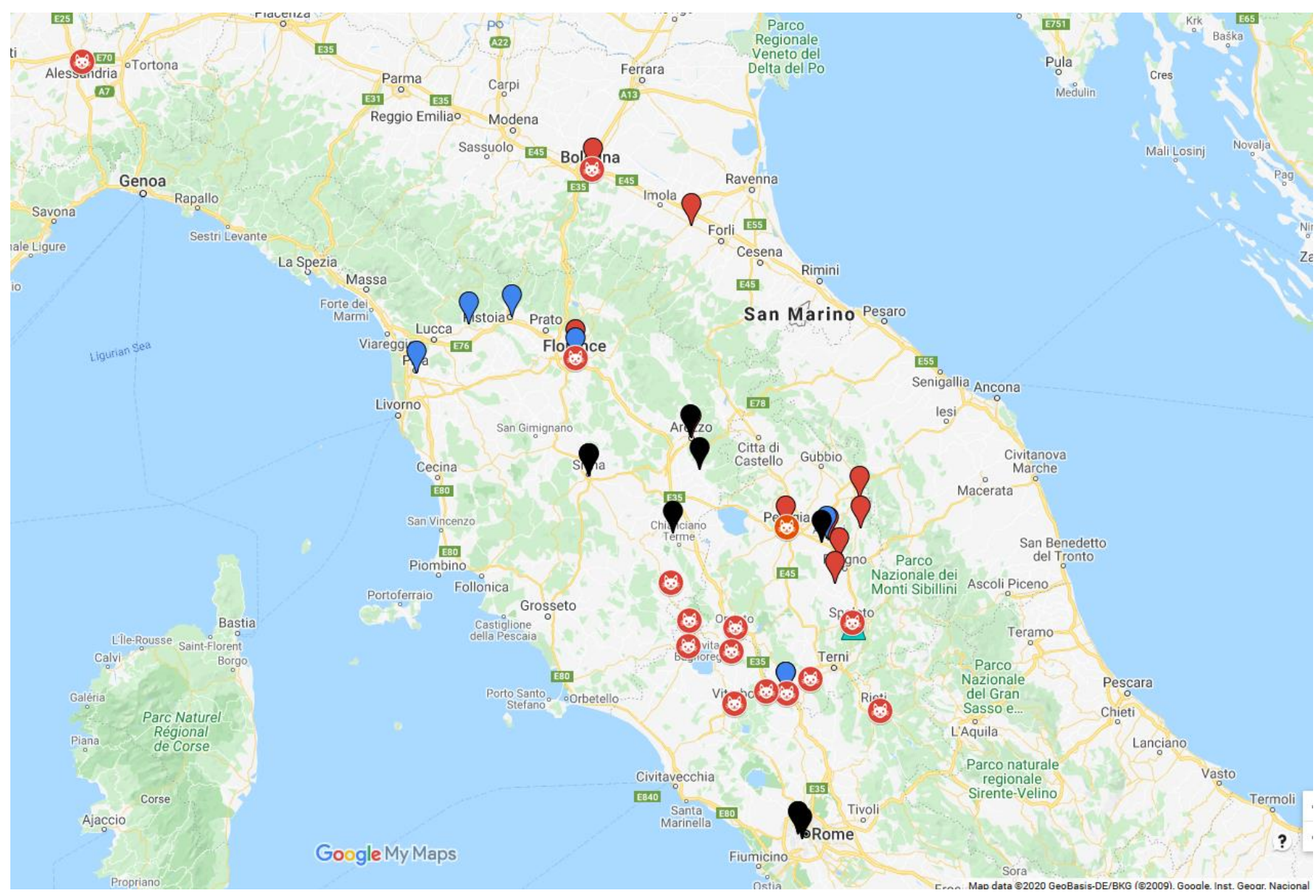

Google Maps https://tinyurl.com/ybzj7w9w

Map data (2020 GeoBasis-DE/BKG (C2009). Google. Inst. Geogr. Nacional.

\section{Map 3 Italy in the Twelfth and Thirteenth Centuries, Adapted from Muir's Historical Atlas (1911)}

https://sourcebooks.fordham.edu/maps/12citaly.jpg 
Born in Saint Louis, Missouri, Rebecca A.H. Ruppar has had a lifelong interest in the intersection of religion, art, and nature. After working as a campus minister and retreat director, she moved to Belgium where she learned to write sacred icons and earned a master's degree in religious studies from Katholieke Universiteit Leuven with a thesis on the religious dimensions of modern art. Returning to the United States, she earned master's and doctor of philosophy degrees in art history and archaeology from the University of Missouri focusing on late antique and medieval European and Byzantine art and architecture. She currently teaches art history and visual culture while trying to find time to explore national parks and old churches. 